UC-NRLF

||||||||||||||| |||||||||||||||||||||||||||

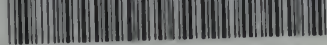

कB $587 \quad 115$ 


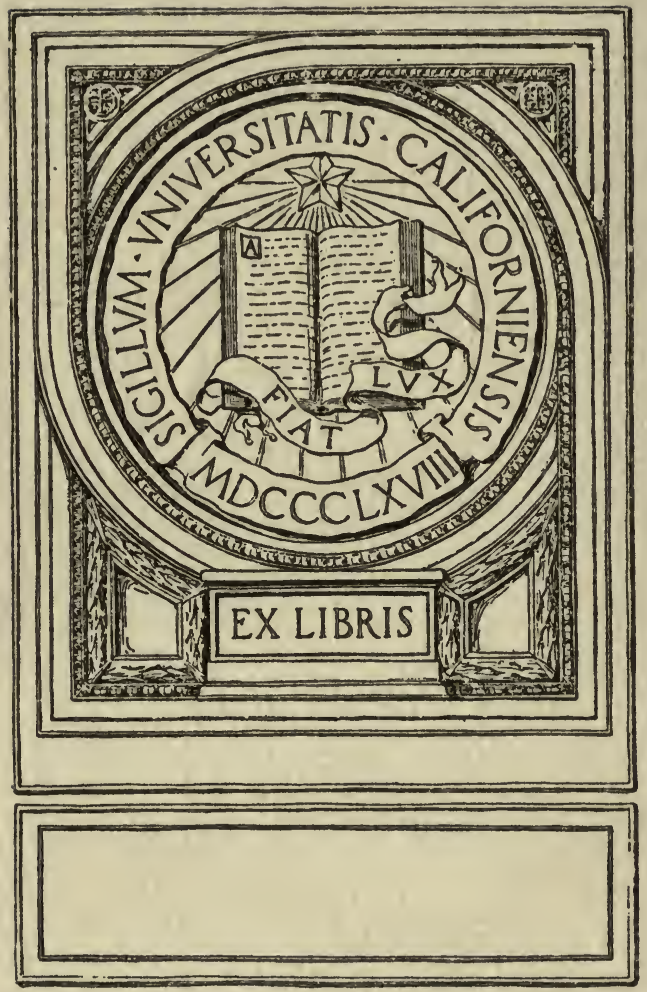


Calendar 1 Statitapens an er 4 wis, $1716+17$

vol 29

$D A$
25

$e_{29}$

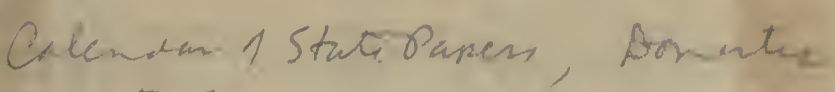

$$
\begin{aligned}
& \begin{array}{l}
\text { DA } \\
\text { Cf } 376
\end{array} \\
& 1547-1704
\end{aligned}
$$


Digitized by the Internet Archive in 2008 with funding from Microsoft Corporation 
A

HISTORICAL GEOGRAPHY

OF THE

BRITISH COLONNIES

\author{
VOL. V-PART IV \\ NEWFOUNDLAND
}

\author{
BY \\ J. D. ROGERS \\ BARRISTER-AT-LAW \\ FORMERLY STOWELL FELLOW OF UNIVERSITY COLLEGE, OXFORD
}

WITH MAPS

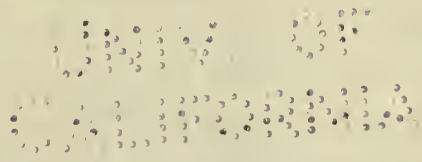

OXFORD

AT THE CLARENDON PRESS

MDCCCCXI 


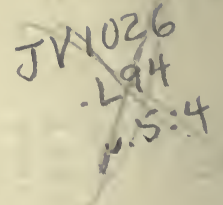

HENRY FROWDE, M.A. PUBLISHER TO THE UNIVERSITY OF OXFORD LONDON, EDINBURGH, NEW YORK TORONTO AND MELBOURNE

\section{HISTORY I}

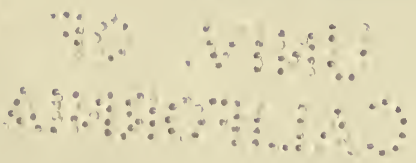




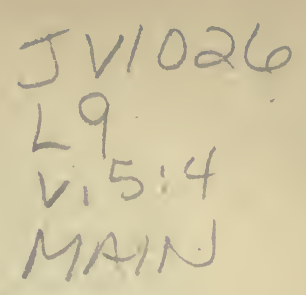

\section{P R E F A C E}

WHEN this series was projected it seemed likely that before its completion Newfoundland would have been absorbed into the Dominion of Canada ; and in 1896 the second edition of Judge Prowse's well-known history of Newfoundland assumed that this fate was imminent. Had these forecasts been fulfilled this volume would have been reduced to a size a little larger than that which has been allotted to those chapters of the Fifth Volume which deal with Nova Scotia. But Newfoundland has not been absorbed, and still remains sui generis and an exception to the rule in the British Empire ;-therefore this book will also be an exception to the other books in this series, and is framed on somewhat different lines and on a rather larger scale.

I do not wish to suggest that the apartness of Newfoundland will continue. Some people think that the island of the United Kingdom which lies nearest to America is destined to draw furthest away from its European sister-realms, and that similarly the island of America which lies nearest to Europe is destined to draw furthest away from its sister Dominions on the continent of America; while other people think that the centrifugal forces of to-day will be succeeded by the cohesive forces of to-morrow, and that present tendencies are due to passing whims. I do not think at all about these things, but take facts as they are. The 
apartness of Newfoundland from the rest of British America has persisted for a long time, and its history has for many centuries contrasted with the history of other colonies in two or three essential characteristics, each of which, strange to say, alternately daunts and fascinates the student.

In the first place there is an immobility in the history of Newfoundland, and a fixity of character in the Newfoundlander, which is unique in colonial history. Somersetshire, Devonshire, and Irish peasants are there and have been there from the first or almost from the first, preserving their ancient types, partly it is true by constant movements between their old and new homes, but partly also from other causes. These things presage monotony. On the other hand, Newfoundland has lived a continuous life and has kept its identity inviolate for more than 300 years. Its earliest years were surrounded by the thrilling incidents of the heroic age of European history, its middle years were disturbed by the din of the three Anglo-French duels, and even its latest years enshrine bygone prejudices, which it requires some historical imagination to reconstruct. There is always interest in a long life; and the long life which is a doubtful and a threatened life, and over which swords hang by threads, is doubly interesting. The uncertainty of its fate is the second characteristic which distinguishes the history of Newfoundland from that of other colonies.

For three hundred years, that is to say, during the whole of its colonial life, the colony has been menaced with complete or partial extinction; not by force but 
by incessantly reiterated arguments. From the very beginning until the very end of its life clever people proved over and over again almost to demonstration that the colony ought not to exist; and vital controversies raged from $I 6 I I$ to $I 8 I 7$ between settlers and nonsettlers, from 1662 to $I_{7} I_{4}$ between French and English, from $\mathrm{I} 763$ to 1904 once more between French and English, from 1783 to September I910-when this book was in page-proof-between American citizens and the colonial or Imperial authorities; and of all stale unprofitable things argument, proof, and controversy seem worst to those who regard history as a tragic stage rather than as a school of formal logic or a court of law. Historians want their authorities to present characters and events, such as those which Holinshed furnished to Shakespeare, but three-fourths of the authorities on the history of Newfoundland grind out interminable premisses and conclusions in the style of Tidd's Practice. One-sided statements of Claim, Defence, and Counter-Claim casuistically and drearily confuted or confirmed one another for three hundred years. Between 1675 and 1757 the very admirals and captains of the Royal Navy wrote some fifty or a hundred annual answers to some fifty or a hundred annual interrogatories, with that glib sameness and definiteness which is only too familiar to lawyers. It might therefore be feared that worse than legal cobwebs would obscure the volumes in which the history of Newfoundland is written.

But another aspect of the same picture presents itself to those who use their imagination. Controversy, after all, was only the sign and symptom of the half-and-half 
existence which Newfoundland led for so long a time; and this half-and-half existence was only the effect of ideas of past centuries, into which we must think ourselves back. Modern writers often allude to these ideas with the condescension or contempt with which dwellers in sunlight speak of those who dwell in twilight, forgetting that twilight has a beauty and a mystery of its own. Moreover, the half-and-half existence of Newfoundland, the twilight so to speak of its history, invariably had a meaning, some reason for its being, some necessity which explained and justified it. This meaning seemed to change from time to time.

In the sixteenth century twilight brooded over all the civilized world and was the herald of that dawn which broke elsewhere but not in Newfoundland. In the seventeenth and eighteenth centuries the dimness of the history of Newfoundland recalled that chronic mist which in poetic visions environs the shadows of those who have been or are about to be. In the Nineteenth Century philosophers complacently classed Newfoundland with obsolete and obscure survivals, and pointed to Newfoundlanders as examples of the tyranny of Custom. But there was a deeper and more permanent reason for the dubious existence of the colony as a colony.

Hunters and fishermen are always the boldest of pioneers and often the homeliest of men, when their hunting and fishing season is over. These pursuits teach their votaries to annihilate space, and then either drive them back to the very villages in which they were born, or make them converts or reverts to savagery. 
The example of fishermen and hunters makes stay-athomes stray from home; and most of those who follow this example are neither fishermen nor hunters, but settlers. Then comes a crisis. Hunters and fishermen oppose settlers-for settlers and wild beasts are incompatible; and there is war-as in Manitoba-in which wild beasts and hunters disappear; or there is absorption-even as the whalers of Cook Strait, New Zealand, were merged into the settlers, and the whales disappeared; or there is absorption of another kind and all the settlers are transformed into fishermen, and none of the fish disappear. This last process took place in Newfoundland, and nowhere else in the world. Indeed, there are few other places in the world where fishing could have continued, if all the settlers, who followed in the wake of all the fishermen, had become fishermen. It continued and continues in Newfoundland, first because the fisheries are practically inexhaustible, secondly because creeks and nooks in or from which fishing can be carried on by settlers are practically innumerable.

Therefore for many centuries fishermen, who went and fished off Newfoundland but returned yearly to their cottages in the south-west of England, existed side by. side with colonists who lived and fished in Newfoundland; so that the colony was something more than a fishing ground, and something less than a colony, in the sense in which the word colony is generally used. Regarded by itself and apart Newfoundland was only half alive. It still remained a physical part of its mother. Thus Fishery proved the earliest and greatest 
stimulus, and the latest and greatest obstacle to colonization, if by colonization we mean the creation of some distant and distinct unit with a separate life of its own.

Early and arrested development was not merely due to the pursuits of those who went to or lived in Newfoundland, but was also due to the spirit of initiative and ambition which animated Elizabethans, and to the profound conviction which animated the political successors to the Elizabethans, that England must increase the English population, and must strengthen the English navy. The theories and policies based on this conviction had many forms and phases, of which the underlying truth is nowadays less apparent than the fallacy. This conviction, or some form or phase of it, produced far-reaching effects on the whole Atlantic coast, but its effects were most conspicuous in Newfoundland, where the natural habits of the local fishermen reinforced the artificial philosophy of the mothercountry.

For these reasons Newfoundland has a history peculiar to itself, and is put into a book by itself; and in order that the picture may be complete I have begun at the beginning, at the risk of repetition, and I have discussed forgotten beliefs and abandoned ideals, which affected the colonization of what once was British America almost as much as they affected the colonization or semi-colonization of Newfoundland.

I cannot pretend to regret this extension of my task, for while I found the unchangeableness of my theme and its atmosphere of argument somewhat repellent, 
I was always entranced by the strange half-lights, the shifting ideas, and the obedience to natural law, which the scene displayed.

Down to I757 my materials were chiefly gathered from the Record Office and the Manuscript Department of the British Museum, to whose officials I am indebted for their courtesy; after 1757 the Record Office was obliged by its regulations to close its doors to me, and I was thrown back on contemporary writers, on Blue books, and on those second-hand authors, who have had access to first-hand authorities which I have not had. When I differ from what I have called secondhand authors, it must not be supposed that I have not considered or do not respect because I do not mention their opinions. I have neither room nor taste for discussion. History from my point of view has only to do with the movement of events. If I differ from any official point of view in any current or recent controversy, the same thing must be borne in mind, and it must be also remembered that I have not seen a single unprinted document between 1757 and the present day, that I do not know for instance what was argued at the Hague, and that I write as a pure impressionist. 



\section{CONTENTS}

Chap. I. International Discoveries . . . 3

II. INTERNATIONAL FISHERIES AND AN IMPERFECT FNGLISH COLONY IN NEWFOUNDLAND . . . . . . $\quad$ I8

III. THE FIRST BEGINNINGS OF A PERFECT ENGlish Colony in NEWFoundland • 45

IV. THE CRISIS AND THE CONvOYS, 1656-88 • 75

V. THE FIRST ANGLO-French DUEL AND ENGLISH VICTORY, I6I8-I7I3

VI. A Half-Century of Progress, I713-63. The SeCond ANGLO-FrenCH DUel AND ENGLISH VICTORY .. . . . 109

VII. The THIRD ANGLO-French DUEL AND ENGLISH VICTORY; AND THE BEGINNINGS OF PERMANENCE, 1763-1818 • I30

VIII. PROGRESS BY LAND DURING THE LAST PERIOD, I818-I9IO . . . . . 159

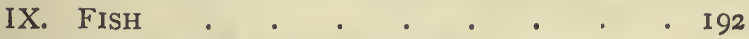
X. BAIT-FISH-EXPANSION-AND CONFLICT . 209

\section{APPENDICES}

Appendix A. Sir Humphrey Gilbert's Plans to ANNOY THE King OF SPain, I577 • 242

B. Sir Francis Walsingham's Plan to ANNOY THE KING OF SPAIN, 1585 • 246

C. InSTRUCtIONS TO SIR JOHN GILBERT, OCTOBER IO, I585 . . . . . 247 
Appendix D. Charles Leigh's 'Brief Platform FOR A VOYAGE', OCTOBER 4, I597

PAGE

E. The Colonization of NewfoundLAND ADVOCATED FOR PURPOSES OF TRADE, ?1600 $\quad . \quad . \quad . \quad . \quad$. 250

F. The Atlantic Fisheries ARbiTRATION: AWARD OF THE HAGUE TRIBUNAL AS PUblished SePtember 8, 1910

INDEX

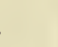

\section{LIST OF MAPS}

Newfoundland

Part of Labrador

Avalon Peninsula

Captain John Mason's map of Newfoundland 


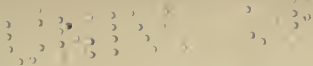

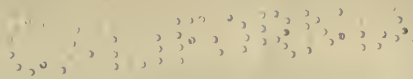



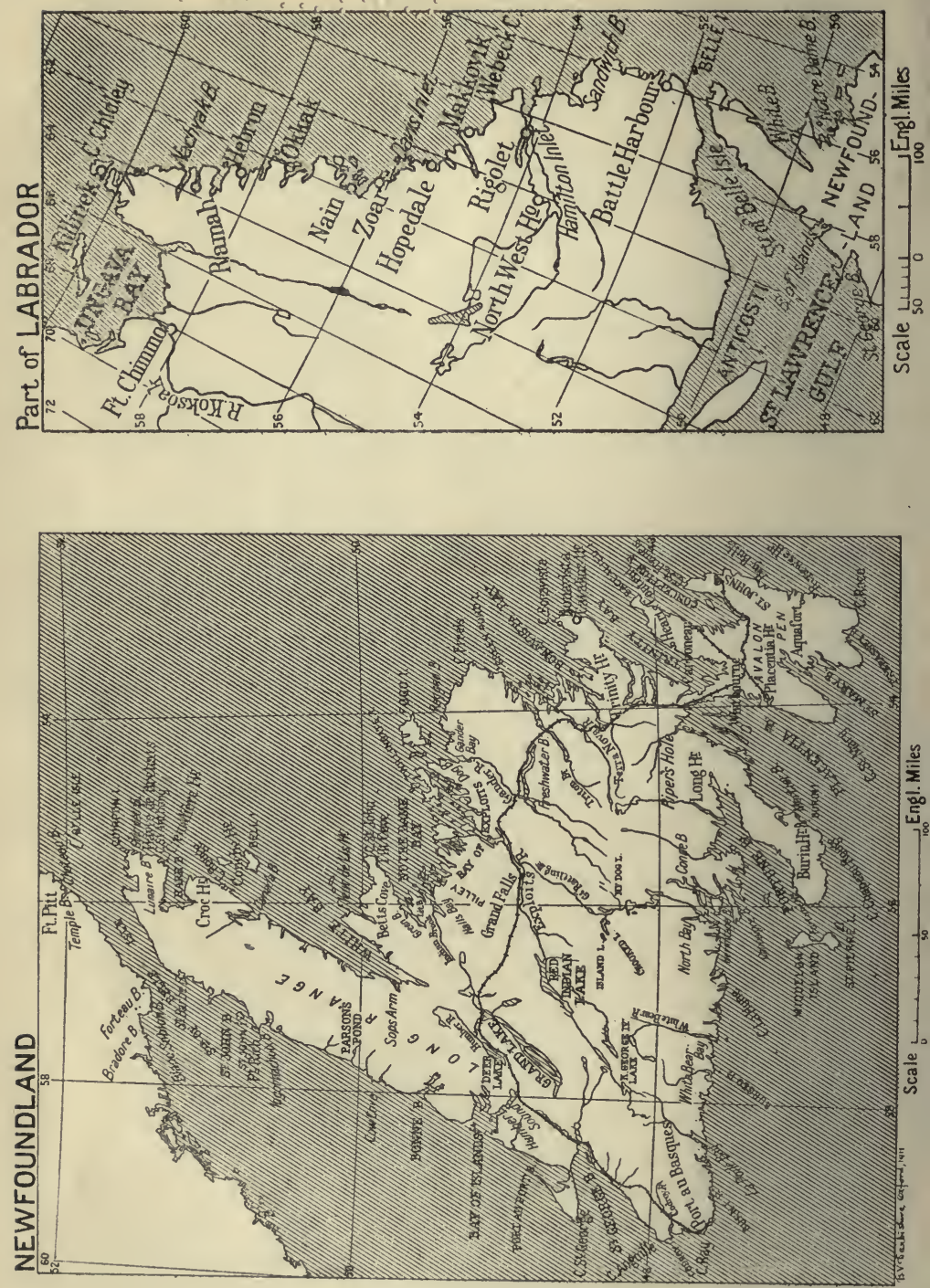


\section{PART IV \\ NEWFOUNDLAND}

\section{CHAPTER I}

\section{INTERNATIONAL DISCOVERIES}

NEWFOUNDLAND-our earliest existing colony-became Icelanders known at the earliest dawn of modern history, and those discovered people who lived nearest to it were the first to find it. and tried to colonize

In A.D. 874 Norsemen discovered Iceland, which is on North America, the way between arctic Europe and arctic America; and including a century later Eric the Red went from Iceland with his Nervfoundfamily and his retainers to the south-west coast of the arctic rooo-6, continent of Greenland, and traces of where they dwelt may still be seen. ${ }^{1}$ Eric's son Leiv, while returning from Norway to Greenland in A.D. rooo, was driven by the wind southward to a land where self-sown corn, vines, and maples ${ }^{2}$ grew, but reached Greenland in the same year. The new land was called Vineland (Vinland), and was sought by Leiv's brother in A.D. IOOI without being found. In 1003 an Icelander, Karlsevne by name, with his wife, who was Eric's daughter-in-law, Karlsevne's friend Bjarni,Eric's son Thorvald, Eric's son-in-law Thorvard, with his wife Freydis, and Eric's hunter Thorhallr, sailed from the Greenland colony with three ships, I60 men ${ }^{3}$, and some cattle, to 'colonize' the new land. The north wind blew, and wafted them in two days or so to barren lands, haunted with white foxes, and strewn with slabs of stone twenty-four feet long; and this they called Slabland (Helluland). A few days' further sail to

1 Near Julianehaab. 3 'Alls 40 manna ok hundrad.'

2 Masur trees. 
the south brought them to a land where the scenery was softer, where (white) bears and (rein-) deer were abundant, and where the coasts were green with trees, and there was an island on its south-east, and they named the land Woodland (Markland); and a day or two later they reached a promontory which they named Keel-ness (Kjalarnes), rounded it, passed along a sandy coast, and shot into a frith with an island in front of it, where they could scarcely walk, because eggs lay so thick there, and they named the frith Stream-fjord (Straumfjörd). There they gathered grapes and self-sown corn and spent the winter (1003-4). Next year Thorhallr's ship turned north and was never seen again, and the other two ships went a little further south to a place by a river-mouth, and the place was named Hópi, which means an estuary. There dusky wide-cheeked Skraelings, as the Norsemen called the (Eskimo) natives, visited them, bartered with them, fled because a bull bellowed, returned with weapons, and joined battle. So the colonists re-embarked (1005), and reached Stream-fjord, and some of them re-rounded Keel-ness, coasted westwards with primeval forests on their left, searched for but failed to find Thorhallr, lost Thorvald at Cross-ness (Krossanes), and saw the backs of the mountains whose fronts they had seen at Hopi. One more winter was spent at Stream-fjord, where Freydis and the women proved the source of strife. Then (I006) the wanderers returned homeward, having taken two Skraeling children in Woodland on the way, but not the children's parents, who 'went down into the earth'. Karlsevne and his crew reached Eric's abode, but Bjarni was driven out of his course, and his ship was eaten of worms somewhere off Ireland, and he perished.

The deeds of these early colonists or 'builders', as they called themselves, stimulated a curiosity which time has not quenched, and men still ask, if Slabland is Labrador, or the equally desolate north-east coast of Newfoundland. Is Woodland the south-east coast of Newfoundland, Keel-ness 
Cape Breton, and Stream-fjord the Gut of Canso? Is Hopi on the south-east, and Cross-ness on the north-west coast of Nova Scotia ${ }^{1}$ ? Or are we on still more historic ground, and is Keel-ness Cape Cod? Is the island on the frith Nantucket? Is Hopi Rhode Island, and is Crossness near Boston ${ }^{2}$ ? Whichever view we take, it is quite clear that Labrador, Newfoundland, and some parts of the American continent were visited by a party of colonists between A.D. 1000 and A.D. 1006, and were described with unerring fidelity. The visit was not repeated, and even Greenland, from whose shores the visitors had come, was abandoned because trade, ambition, lust, and religion drew the builders of greater Norway elsewhere. It was ever the Norse instinct to seek and adorn lands more civilized than their own; so Norway ceased to send lowly settlers to the lonely wilds of Greenland and America, and began to scatter broadcast up and down the crowded capital cities of Europe counts and dukes and kings. The Norse discovery of Newfoundland and America was the false dawn, and many events were destined to happen before the real dawn appeared.

At the very moment when Eric's sons and sons-in-law and while daughters-in-law and their husbands opened a side-door in America for fellow Europeans to enter in, Hakem the Mad slammed the main door of Asia in the face of European muropeans, merchants and pilgrims. The Crusades followed; the depths thereby of fanaticism were stirred; there was an era of stress and causing the storm; as men go mad or are inspired, so the nations of Europe went mad or were inspired ; but at last there was peace, and the and the borderland between Asia and Europe was occupied Itactories by a chain of Italian factories in alien cities, which formed between the connecting link between Europe and 'the wealth of Esia and

1 Sic Dr. Gustav Storm, Studier over Vinlands Reiserne, Vinlands Geografi og Ethnografi, Christiania, 1888.

${ }^{2}$ Sic C. C. Rafn, Antiquitates Americanae, Copenhagen, 1837 ; C. C. Rafn and F. Magnússon, Grönlands historiske Mindesmaerker, 1838 , et seq. 
Ormus and of Ind'. The doomed Venetians clung to their own counting-houses at La Tana, on the Sea of Azov, and at Alexandria. But usually Italians, being nationless, entered which led to the service of other nations. Thus ever since $\mathbf{I} 3 \mathbf{I} 7$ Genoese Italian and
other dis-
sailors were annually imported into Portugal $;{ }^{1}$ and Genoese coveries in sea-captains discovered Madeira, the Cape Verde Islands, Africa and and probably the Azores, for the Portuguese, and the Canaries
America, for the Spaniards. It was a Florentine astronomer, named Toscanelli, who, at the request of Alphonso V of Portugal, wrote his proof that the nearest way to the east lay west, which proof a Genoese servant of Alphonso V, named Columbus, read. The Italians were the guides and teachers, the nations and their kings were the actors. Portugal and Spain were the first to act; each acted differently, but both followed a tradition which was only a distant memory in the rest of Europe. The south-west of Europe, where the old Crusading embers still glowed, was the first to receive the new knowuinder ledge. There Ferdinand and Isabella were stamping out Portugal and Spain, the last vestiges of Mohammedanism by planting internal colonies of a strictly feudal type in Granada; and the Portuguese were feeling their way, headland by headland, and bay by bay, to South Africa, and so to India, or searching vaguely after legendary Atlantic islands, such as Antilia, the Island of Brazil, and the Land of the Seven Cities, or peopling actual Atlantic islands with African slaves whom they stole and converted by the score, or warring with the Moors of Barbary in the name of Him whom the Crusaders thought that they served. Both Portugal and Spain were growing into kingdoms while they colonized. Both in Portuguese and in Spanish ' to colonize ' meant 'to people', whether with foreign slaves or foreign garrisons. Both Portuguese and Spanish progress was blessed by the Pope. Pope Martin V and his successors granted to the Kings of Portugal whatsoever should be discovered between Cape Boiador in West Africa and the

1 E. J. Payne, History of the New World called America, vol. i, p. 8\%. 
easternmost countries washed by the Indian Ocean, and assoilzied those who perished in the conquest. ${ }^{1}$ In 1492 Columbus sailed under the banner of Castille and Aragon due west, as Toscanelli had advised; found, as he fancied, the east coast of Cathay, wherein were gold, silver, and jewels, outshining the splendours of the New Jerusalem; reached, as he declared, the Kingdom of the Great Khan and the site of Sir John Mandeville's Terrestrial Paradise, and meditated the conquest of the old Jerusalem from the east. Such were his gorgeous fancies, but he had only found Cuba, which he mistook for Asia, Hayti, which he mistook for Japan, and some other savage islands. The new printing-presses at Madrid, Rome, Basle, and Paris blazoned his fame far and wide. Pope Alexander VI issued four Bulls, which-after and to reciting the grants to Portugal, the expulsion of the Moors the Partifrom Granada, and the exploits of Columbus, as though they 1494 by were incidents of a Crusade-drew a line of longitude one Bulls hundred leagues west of the Azores or Cape Verde Islands, not clearly and conferred on Ferdinand and Isabella all lands discovered or to be discovered west of that line of longitude, south of America, the latitude of those islands, and east of India. ${ }^{2}$ The same Bulls excommunicated discoverers, fishers, traders, and travellers within the new Spanish zone, unless they were licensed by the royal monopolists. The very seas were tabooed to tourists. After the four Bulls came a treaty and by the between Portugal and Spain, known as the Treaty of Treaty of Tordesillas (1494), which readjusted their boundaries in the sillas, unknown world. The line of longitude was shifted by the rohich did treaty to a position 370 leagues west of the Cape Verde third Islands; the partitioned world was not limited by any line parties. $^{\text {ba }}$ of latitude; the partitioned sea was free-except to discoverers, conquerors, and traders-and Spanish fleets might cross the

1 Purchas, Pilgrims, ed. 1905 , vol. ii, p. 14.

2 Reale Commissione Colombiana: Raccolta di Documenti e Studi, Pt. III, vol. i, Rome, 1893; Purchas, Pilgrims, vol. ii, p. 34. The line of latitude is ambiguously expressed. 
Portuguese Atlantic. There was no Papal thunder, but only a contract, which could scarcely bind States which were not parties to the contract. The limit of latitude, $40^{\circ}$, which figured in the Bulls, made the occupation of Carolina, Virginia, Maryland, and Pennsylvania, but did not make the occupation of New England, Newfoundland, and Canada, an offence against the Pope. No one could draw the line of longitude which figured in the Bulls and in the treaty, but most people thought that the longitude adopted by the treaty assigned Newfoundland to Portugal. If so, they thought wrongly. ${ }^{1}$ Spain never claimed North-east America. At one time Portugal seemed about to claim it, but desisted. Being in danger of either, it suffered from neither.

North-east America was rediscovered by J. Cabot,

The discovery of North-east America was the next important event in the history of the world, and the two discoveries resembled one another as moonlight resembles sunlight. The central gates of America and of modern history were flung wide open by a man steeped in the reveries of an age, which was irrevocably gone, and drunk with desires, which were not destined to be fulfilled, amid strains of triumph from popes, kings, philosophers, nobles, merchants, and all the orchestra of Europe. In Columbus old and new met; the last rays of sunset mingled with the first rays of sunrise, and the votaries of the vanished past were even louder than those, who wore their eyes in front of their faces, in applauding this apostle of an Italian transition. The side-door of North-east America was pushed from the eastern open by John Cabot, who was also a Genoese, who had also factories, served many masters and had become a naturalized Venetian ( 1476 ), who had also seen the Venetian factories in the East, and had been at La Tana and Alexandria, and who now resolved to outdo his compatriot. His master was the King of England, to whom Columbus had also offered his 'invention' (1488); and his associates were Englishmen, who had

1 If a league $=3$ sea-miles, 370 leagues west of Cape Verde Islands = lat. $45^{\circ} \mathrm{W}$. long. 
been in Iceland, where Columbus also had been. His origin, ideas, associations, and deeds resembled those of Columbus; but, unlike Columbus, he stole into America noiselessly, unpraised, without the halo of romance, and more like a thief in the night than a conqueror. His base of operation was Bristol, where Europe-if England can be called a part of Europe-is nearest to America, if Newfoundland can be called a part of America.

For a century or more Bristol had been sending annual with Brisfleets to Iceland to bring back dried cod or stockfish; and tol ships, the sailors doubtless learned the Icelandic stories of imaginary islands in the west named Friesland, ${ }^{1}$ Big Ireland, Estotiland, ${ }^{2}$ and the like, and heard, perchance, news of the 'New Land', which Eric's kith and kin 'found '. ${ }^{3}$ Indeed, in A.D. I 480 two Bristol ships are said to have searched for Big Ireland, so that Bristol was as opportune spiritually, as it was geographically for the new departure.4 On March 5, I 496, Henry VII under an granted to John Cabot, his three sons, and their heirs, English a patent to sail east, west, and north under the English flag, 1496 , to conquer, annex, and govern under the English Crown lands unknown to Christians, to exclude visitors thither, and to import wares thence into Bristol, customs-free, paying onefifth of the net profits of each voyage to the English king. ${ }^{5}$ De Puebla, the lynx-eyed Spanish ambassador in London, instantly wrote to his master, that a second Columbus was about to do for Henry VII, what Columbus had done for him, but 'without prejudice to Spain or Portugal'. 'If so,' replied King Ferdinand, March 28, 'King Henry should be free to do so. But De Puebla was to warn him that it was a snare laid by the King of France to divert him from enterprises of greater pith and moment, that it would probably

1 Friesland, The Faroes: J. R. Forster, Geschichte der Entdeckungen und Schiffahten im Norden, 1784, p. 220.

2 Hakluyt Society Publications, vol. 1.

4 Sic William of Worcester.

5 Hakluyt, Principal Navigations, vol. vii, p. I4I.

3 Nye Land. 
prove a delusion, and must inevitably prejudice the rights of Spain or Portugal under the Treaty of Tordesillas.' 1 Seventeen months elapsed before two Italian letter-writers continued

in his voyage of I 497 , the story which the Spanish official began. On August 23, I 497, Lorenzo Pasqualigo, a Venetian merchant resident in London, wrote to his brother in Venice: 'Our Venetian, who went with one Bristol ship to find new islands, has returned, and says that he found 700 leagues from here a continent which is the country of the Gram Cham (sic). He sailed along the coast for 300 leagues, landed, and found no one, but brought back snares for game and a netting-needle. He was three months on his voyage. The tides there were feeble. On turning back ${ }^{2}$ he saw two islands, but would not land, as his victuals were running short. The King is delighted, and has promised him next spring ten ships equipped according to his wishes, and has given him all the prisoners (except traitors) he wants to sail with him. He calls himself the grand admiral, and walks abroad in silk attire, Englishmen running after him like madmen. On taking possession, he hoisted the Venetian as well as the English flag.' ${ }^{3}$

Hardly less alert than Pasqualigo, Raimondo di Raimondi, Archpriest of Soncino, wrote to Duke Sforza of Milan, August 24, and December 18, I497, that 'John Cabot had started out with a royal commission some months past, that he had discovered the Seven Cities and two very big and fertile islands, that he had taken possession, and that Henry VII had gained a part of Asia without striking a blow. After passing Ireland, Cabot steered north, then east (sic). ${ }^{4} \quad$ A penniless foreigner like him would not have been believed had not his companions, almost all of whom

1 Reale Commissione Colombiana: Raccolta di Documenti e Studi, Pt. V, vol. ii, p. 217, Rome, 1893. My quotations from these letters in the $R . C . C$. are all abridged.

2 Aldreto = 'back', not 'to the right'.

3 Reale Commissione Colombiana, Pt. III, vol. ii, p. 109; Calendar of State Papers, Venetian Series, vol. i, p. 262.

+ Confusing the objective (Asia) with the direction (west). 
were Englishmen from Bristol, confirmed his story. The companions declared that the sea there was so full of fish, that they were taken in hampers each weighted with a stone, and that England would no longer need Iceland, whence the so-called "stochfissi" (sic) had hitherto come. Cabot thought not of fish, but only of the spices of Japan which he had seen at Mecca. The king granted him a pension, and intended to give him "all the criminals", wherewith he might found a factory or colony (colonia), by means of which London would excel Alexandria as a spicemarket. Great Bristol mariners, who were at the head of the undertaking, averred that they could with luck sail thither in fifteen days. Cabot had already given islands to a barber, and to a Burgundian, who called themselves Counts, while Monsignor the Admiral gave himself the airs of a prince. The writer might have obtained from him an archbishopric, but preferred his present humble post as more secure'.' At the very same time a Scotch priest, who also hungered after ecclesiastical preferment, wrote that

'It micht have cummin in schortar quhyll

Fra Calyecot and the new-fund Yle

The partie of Transmeridiane

Quhilk to considder is ane pane'

But he too stayed at home. ${ }^{2}$

Another pause ensued, during which Pasqualigo and Raimondi's pleasant gossipings, and De Puebla's whispered confidences are hushed, and we are fain to munch dry bones like the following. The king gave $f_{\text {ro }}$ 'to him that found the New Isle', August 1o, $1497 ;^{3}$ and an annual pension of $\AA_{2} \circ$ to John Cabot, December I3, I 497, which pension was drawn twice. During March and April, 1498, the king gave further sums, amounting to $£_{72}$, to Launcelot Thirkill,

1 Reale Commissione Colombiana, Pt. III, vol. i, pp. 196-8.

2 W. Dunbar, World's Instability.

3 S. Bentley, Excerpta Historica, 1831, p. I1 3 .

4 Customs' Roll of the Port of Bristol, 1496-9, edited by. E. Scott, A. E. Hudd, \&c., and published in 1897 . 
Thomas Bradley, and John Carter, in order to promote a new expedition ' to the new isle', and granted a new patent to John Cabot to take English ships and mariners 'to the land and isles of late found by the said John'.'

and his voyage of 1498 ,

Then letter-writers once more picked up the interrupted thread. On July 25, 1498, De Puebla and De Ayala, both of the Spanish embassy in London, wrote to their master that ' Henry VII had dispatched a fleet of five ships, victualled for a year, in order to discover certain islands and continents, which Bristol merchants declared that they had found last year. The writers had seen the chart of the discoverer, who was another Genoese like Columbus, and had been in Seville and Lisbon seeking helpers. Inspired by the Genoese adventurer, the men of Bristol had for the last seven years been sending annual fleets in quest of the mythical Seven Cities and Island of Brazil. Judging by his course, what had been found belonged to the Spanish sphere within the meaning of the Treaty of Tordesillas. The writers were informed that it was only four hundred leagues away, but the chart which had been shown them was probably falsified. ${ }^{2}$ The King of England was intensely interested in the venture, and misliked the writers' suggestion that these discoveries had been anticipated by Spain. The latest news of the present expedition was that one ship had encountered storms and had put back to Ireland, but that the Genoese held on his course. They expected to arrive in September'. ${ }^{\text {. }}$

which The bundle of letters is ended, and the patent rolls and voyages raise many unsettled account books are silent; yet they have told us all we know for certain of the voyages of 1497 and 1498 , and all we questions. know or ever shall know of John Cabot, who now finally vanishes from the scene. It is fairly clear that John Cabot hit Newfoundland, which is the nearest point in America to

1 Hakluyt Sociely Pullications, 1850, vol. vii, p. Ixxii.

2 If 1,200 miles distant it would be within the Portuguese sphere. Columbus kept two logs, one for purposes of deception.

${ }^{3}$ Reale Commissione Colombiana, Pt. V, vol. ii, p. 218. 
England, and about seven hundred leagues or (with luck) fifteen days distant, ${ }^{1}$ and whose 'tides' are generally so small that they are practically disregarded' $;{ }^{2}$ and he can hardly have coasted three hundred leagues without hitting the then undiscovered mainland of America. Moreover, three years later an Italian sword and Venetian earrings were seen in Labrador, a little north of Newfoundland, ${ }^{3}$ and in A.D. I 500 a map named a cape, apparently in Labrador, "the Cape of England," and scattered along hundreds of miles of coast to the south of it names which John Cabot must have given. What is said is only a little less explicit than the Sagas of Eric the Red; but what is unsaid is far more perplexing than what is said. 'The Genoese held on his way'; but whither? Did he join 'the lost adventurers his peers'? Did he end, like La Pérouse, or not end, like Vanderdecken? Are these words an epitaph or a preface? Or was the end of the voyage too humdrum to be recorded $?^{5}$ And were those three raw-meat-eating savages, who were caught in ' the Newfound Island ' at the end of 1498 , and exhibited to the king then or in $1502,{ }^{6}$ the fruits of this, or of the former, or of some other unrecorded expedition? Historians deepened the mystery. In the next century, when Amerigo, Cabral, Cortez, and Pizarro intensified European interest in American discovery, histories of discovery were written, and all the historians derived their knowledge of John Cabot from Sebastian, his eldest son-who, according to one con-

1 E. Haie says 700 leagues, post, p. 38. Captain John Mason, Discourse of the Newfoundland, 1620 , says 14 to 20 days thither, 12, 16, or 20 days thence in good weather. Comp. W. Grenfell, Labrador (1910), P. 320.

2 Juke's Excursions in Newfoundland, 1839-40, vol. i, p. 64.

3 Letter of P. Pasqualigo, October 19, I 501 : Reale Commissione Colombiana, Pt. III, vol. i, p. 9 o.

4 Cavo de Inglaterra. See Juan de la Cosa's map. H. Harrisse, Discovery of America, 1892, vol. i, p. 42 .

5 Sic G. P. Winship, Cabot Bibliography, 19oo. Compare H. P. Biggar, Voyages of the Cabots and Cortereals, Paris, I903.

${ }^{\circ}$ Hakluyt, Principal Navigations, vol. vii, p. I55; Stow, Annals, p. 485 . 
temporary account, had never been in America ( $\mathbf{5}_{52} \mathbf{r}^{1}$ - and declared on Sebastian's authority, that it was not John but Sebastian who was the discoverer, and that John died before the discovery occurred. Thus Sebastian poisoned the wells of history in order to glorify himself at his father's expense. In the above account the testimony of those, who drank at this tainted source, has been rejected. ${ }^{2}$

Portuguese The scene shifts once more to Portugal. In 1499 King under Portugal took on the task, I 5OI-3, Manoel granted to João Fernandes, a husbandman (Lavrador) of Terceira in the Azores, who had already (1492-5) explored the northern seas, a patent to discover and rule new islands within the Portuguese sphere. ${ }^{3}$ Such patents were common, sometimes (1482) including 'the Seven Cities', and a similar patent was granted to Gaspar Cortereal, also of Terceira, who in $5_{501}$ explored Labrador from $58^{\circ} \mathrm{N}$. lat. downwards to Conception Bay or thereabouts in Newfoundland. Like their Icelandic and English predecessors, the Portuguese approached Newfoundland from the shores of Labrador; but unlike Karlsevne and Cabot, Gaspar meant business, and business was the Portuguese equivalent for slaves; so that when his ships returned with fifty-seven kidnapped natives-who were tattooed on their cheeks, and were therefore Nascaupi Indians from Labrador-and with timber or news of timber in the inlets of south-eastern Labrador, the king was glad. But Gaspar did not return. Next year his brother Miguel headed a search-party, and examined the east coasts, and named the east capes and harbours of Newfoundland, after which his three vessels resorted to Cape Spear or St. John's Harbour as their rendezvous, but returned home without Miguel. A third search-party was organized and failed, after which there

1 H. Harrisse, op. cit., vol. iii, p. 749.

2 Pietro Martire, Gomara, Ramusio, Fabyan, as cited by Hakluyt, Stowe, Bacon, \&cc.

3 E. do Canto, 'Quem den o nome ao Labrador ?', 1894, reprinted from Archivo dos Azores, a periodical published at Ponta Delgada, vol. xii, pp. 355-71 ; Ibid., Os Corte-Reaes, I883, p. 73 ; Harrisse, Les Corte-Real, p. 44 n. 
were no more search-parties either for Gaspar or Miguel. Portugal had already passed the Cape of Good Hope (r 497) and annexed Brazil ( 1500 ); and the heirs of the Cortereals found it easier to stay at home, and rule their domain in 'Terra Nova', in the same way as their neighbour, the 'aery burgomaster' of 'the Seven Cities' of mediaeval myth, ruled his. They still enjoyed the empty title in $\mathbf{I}_{567}$. However, it is not with the Cortereals, but with João Fernandes, that we are concerned.

In 1501 João Fernandes and two other Portuguese joined so did other three Bristol merchants, named Ashhurst, Warde, and Thomas, Portug and obtained from Henry VII a patent resembling Cabot's England, patent, but only conferring monopolies for a term of ten years ${ }^{1501-2,}$ or less, and containing powers to wage defensive wars. These two new features characterized every subsequent English patent, which related to Newfoundland. In $\mathbf{1}_{502}$ a second similar Anglo-Portuguese patent was granted to Eliot, a sheriff of Bristol, and three of the former associates. Anglo-Portuguese undertakings of a somewhat similar character were in vogue in East Africa during the sixteenth century, and the method of running adverse claimants in double harness was afterwards pursued in Acadia, and, during the Great Rebellion, in England. The results of the AngloPortuguese experiments are chronicled in the king's accountbooks, according to which $\AA_{33}$ or so was disbursed to Bristol and Portuguese merchants, who went to 'The Newfounde Lande ' or 'Newfounded Island', and brought back thence (or from Portugal ?) hawks, popinjays ${ }^{1}$, wild cats, and mountain cats $^{2}$, in order to gladden the English king, even as Gaspar Cortereal sent back slaves and timber in order to gladden the Portuguese king. ${ }^{3}$

After the Portuguese and Anglo-Portuguese episodes maps after which of North-east America assume something like their present Labrador and New-

$1=$ Parrots. 2 = Martens.

${ }^{3}$ S. Bentley, Excerpta Historica, I831, pp. 126, 129, I3 I bis, г33. 
foundland shape and exhibit familiar names such as Labrador ( 1502 ) were known and Terra Nova (1508): Labrador being named after a 'lavrador' or farmer of the Azores ${ }^{1}$ who was with John Cabot, and being applied sometimes to Greenland, and sometimes to what is now known as Labrador. In maps of the same dates forgotten Portuguese names occur on the coast of Labrador, and familiar Portuguese names on the east coast of Newfoundland; and amongst the latter Cabo de Frey Luis (Cape Freels), Ylha dos Bocalhas (Baccalieu Island), Cabo de Cóçepiçion, Baia da Comceica (Conception Cape and Bay), Cabo de Sam Francisquo (Cape St. Francis), Cabo da Espera (Cape Spear), and Capo Raso ${ }^{2}$ (Cape Race) occupy their present positions. Fogo Island, St. John's, Cape Broyle (Abrolho) ${ }^{3}$, Ferryland (Farelhão) ${ }^{4}$, Aquafort (Aguada) ${ }^{5}$, Fermeuse (Fermoso) ${ }^{6}$, and the Cape and Bay of Boa Vista, which was corrupted-even as Boa Vista in the Cape Verde Islands was corrupted - by the French into Bonne Viste, and by the English into Bonavista, probably date from the same time although they only appear on later maps, for instance in 1534. In a map drawn in ${ }_{1508}$, Placentia Bay, on the east part of the south coast of Newfoundland, and Conception Bay and an amalgam of Trinity and Bonavista Bay on the south part of the east coast, are intelligibly drawn; and the islands of St. Pierre and Miquelon are represented by 'Barbatos In.'. A stranger looking at these maps would surely say, that the whole east coast of Labrador and Newfoundland, and the south coast of Newfoundland, as far west as Placentia Bay, formed one country or sphere of influence, to which Portugal or some anonymous ally of Portugal laid claim; and that the process of State-aided exploration had attained this definite result early in the sixteenth century. As far as England and Newfoundland were concerned, the period of State-aided exploration pure and simple on these coasts lasted from 1497

$$
\begin{aligned}
& 1 \text { João Fernandes?. } \\
& 4 \text { = Rocky. } \\
& 2 \text { = smooth. } \\
& 5 \text { = watering-place. } \\
& \text { s }=\text { Rock. } \\
& 6 \text { - beautiful. }
\end{aligned}
$$


to I502. Not that State efforts were not made from time to time to rediscover what was already discovered. But these efforts were only half serious, or if wholly serious lay too far afield to affect the destinies of Newfoundland. Moreover they were concerned with discovery and adventure rather than with colonization, and the time for colonization had arrived. But the earliest efforts at colonization were unsuccessful, and were inspired by imperfect ideas of what colonization really meant.

\section{Authorities}

The authorities for the first chapter are mainly Icelandic, Norse, Italian, Spanish, and Portuguese.

For the Icelandic voyages I accept the conclusions of Dr. Gustav Storm, Studier over Vinlands Reiserne, Vinlands Geografi og Ethnograf, Christiania, 1888. An English version of Dr. Storm's paper was published by Kongeligt Nordisk Oldskrift-Selskab of Copenhagen under the title of Studies on the Vineland Voyages, 1888.

For Cabot I use the original letters of Pasqualigo, Raimondo, Puebla, Ayala, Cantino, Contarini, \&c., and the Papal Bulls in Reale Commissione Colombiana: Raccolta di Documenti e Studi, published at Rome in I892; Part III, vols. $\mathrm{i}$ and ii, and Part V, vol, ii, of which contain the material documents.

George P. Winship, Cabot Bibliography, r900, which contains nearly 600 items.

Henry Harrisse, Discovery of North Anerica ... including descriptions of 250 maps or globes... constructed before 1536, Three Parts, 1892 ; Les Corte-Real et leurs Voyages au Nouveau Monde, 1883.

H. P. Biggar, Voyages of the Cabots and of the Cortereals to North America and Greenland, 1903 , is very ably argued, but I do not accept his reconstruction of Cabot's voyages, although its possibility is proven.

R. Hakluyt, Principal Navigations, ed. 1904, vol. vii, pp. 133 et.seq.

S. Bentley, Excerpta Historica, 1831.

E. do Canto, Os Corte-Reaes, 1883.

The maps referred to include more especially Juan da Cosa's (1600), the King (I 502), Pilestrina (I504), Reinel (I505), Ruysch (I508), Riccardiana and Viegas ( ${ }_{534}$ ), and Deslien ( ${ }_{54} \mathrm{I}$ ) maps. 


\section{CHAPTER II}

\section{INTERNATIONAI FISHERIES AND AN IMPERFECT FNGIISH COLONY IN NEWFOUNDLAND}

Colonizers THE age of discovery passed away and an age of imperfect

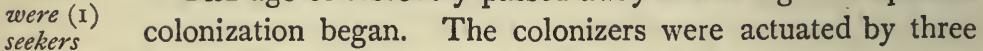
after Asia, different kinds of definite ideas, and definite colonization was (2) fishermen, (3) threefold in its character. In the first place, there were men idealists, who were saturated in the old illusions and ideas, and intended colonization as a means to an end, the end being the gold and silver and spices of Asia. Secondly, there were fishermen, who went to Newfoundland for its own sake, in order to catch fish for the European market, who were without illusions or ideas or any wish to settle, and who belonged to many nations, and thwarted but also paved the way for more serious colonizers. Thirdly, there were idealists who wished to colonize for colonization's sake and to make England great; but in order to make England great they thought it necessary to humble Spain in the dust, and their ideas were destructive as well as creative. All these colonizers bad their special projects, and each project, being inspired by imperfect ideals, failed more or less, or changed its character from time to time. The first and third projects were at one time guided by the same hand; but the first project gradually cast off its colonizing slough, and resolved itself once more into discovery for discovery's sake; and the third project ceased to be a plan of campaign, and resolved itself into sober and peaceful schemes for settling in the land. Even the second project, which was unled, uninspired, unnational, and almost unconscious, and which began and continued as though in obedience to some irresistible and unchangeable natural and economic law, assumed different 
shapes and semblances, as it blended or refused to blend with the patriotic projects of the idealists. These three types of colonization will serve as clues to unravel the tangled skein of my second and third chapters; but it must be remembered that, though they tended in different directions, they were hardly distinguishable in the earlier phases of their history. Perhaps a fourth type should be added, but this or (4) men fourth type was what naturalists call an aberrant type, and $\begin{aligned} & \text { with indis- } \\ & \text { tinct ideas, }\end{aligned}$ only comprised two colonizers, Rut and Hore, whose aims were indistinct, and who had no clear idea where they meant to go, or what they meant to do when they got there.

In I 52 I efforts were made by Henry VIII and Cardinal like Rut Wolsey to induce London and Bristol to make a State-aided and Hore voyage 'into the Newfounde Island'; money was subI 527 scribed $^{1}$; and probably the voyage of John Rut to Chateau (?) Bay in Labrador, ${ }^{2}$ where he found a wilderness of mountain, wood, and moss, and to St. John's Haven, where he found eleven Norman, one Breton, and two Portuguese fishing-vessels, and two English trade-ships, was the outcome of this agitation $\left(1_{527}\right)^{3}$. $^{3}$ Hore's 'voyage of ${ }_{153} 6$; discovery' ( 1536 ) was undertaken by barristers and eastcountry merchants, and 'by the King's favour'. One-fourth of the crew were 'gentlemen', as distinguished from sailors. They sailed to Cape Breton, then to Penguin Island on the south coast of Newfoundland, and to a Bay (somewhere west of Fortune Bay) where they saw savages and white and black bears, but were so starved, that one man killed his mate while stooping to gather herbs, and broiled and ate his buttock. Other men mysteriously disappeared, and the ghastly news reached the captain, who exhorted his crew to repentance and prayer, and 'such was the mercy of God' (the writer is English, not French) 'that the same night there arrived

$1 \mathrm{H}$. Harrisse, Discovery of North America, p. 747.

2 Lat. $5^{\circ}$.

3 Hakluyt, Principal Navigations, vol. viii, p. I ; Purchas, Pilgrims, vol. xiv, p. 304 . 
(I) Eng-

lish seekers after Asia were the northwesterswho afterwards lapsed into mere explorers ;

a French ship in that port well furnished with victual, and such was the policy of the English that they became masters of the same', changed ships, and sailed home. ${ }^{1}$

Voyages with a more definite purpose were undertaken by Sir Martin Frobisher (1576-8), John Davys (1585-7), George Weymouth (I60I), John Knight (I606), Henry Hudson ( 16 ro-r r), Thomas Button (I6I2), William Baffin and Robert Bylot ( $1615-16)$, Luke Fox (163), and Thomas James $\left(16{ }_{3} \mathrm{r}-2\right)$, in order to find a north-west passage to Cathay, and to bring back the gold and silver and other trophies of the storied East. Frobisher, the first of the northwesters, owed his inspiration to Sir Humphrey Gilbert, who presented a petition to the Queen to promote a voyage to Cathay by the north-west $\left({ }_{5} 5^{67}\right),{ }^{2}$ and wrote 'A Discourse to prove a passage by the north-west to Cathaia and the East Indies' ( $\left.{ }_{574}\right)^{3}$, which was the first book which advocated the English colonization of North America. Frobisher made three voyages to Frobisher Bay, on the north of Hudson Strait $\left(\mathrm{I}_{576},{ }^{\prime} 7,{ }^{\prime} 8\right)$, in which he deemed the Bay a Strait, with Asia on his right hand and America on his left hand. He took possession with feudal solemnities, said he was within a few days' journey of Cathay, built a house of stone and lime (which was still there in 1862), and but for an accident to his stores would have left behind one hundred persons, mostly soldiers and gentlemen, in order to spend the winter there $(1578-9)$ or wait until he returned. As with Hore, his gentlemen and soldiers were usually one-third of his company ; and as with his successors, a winter party of one hundred men was to form a bridge between discovery and colonization. Five years later Christopher Carleill proposed, ${ }^{4}$ and seven years later Virginian colonization began with a similar winter party of

1 Hakluyt, Principal Navigations, vol. viii, p. 3 .

2 State Papers, Domestic Series, Elizabeth : Jan. 24, and Feb. (?), I 567.

3 Printed 1576.

4 Hakluyt, Principal Navigations, vol. viii, p. 148 . 
one hundred men. Davys's voyages were undertaken under the auspices of Sir Humphrey Gilbert's brother Adrian Gilbert, of Sir Walter Ralegh, and of other founders of our Colonial Empire. Weymouth's, Knight's, Hudson's, Button's, Baffin's, and Fox's patrons were the founders of our East Indian Empire; Davys was assisted by the merchants of Exeter; James was assisted by those merchants of Bristol, to whom the first permanent settlements in Newfoundland were due; and great colonial statesmen like Sir Francis Walsingham, Robert Cecil Earl of Salisbury, and Henry Earl of Southampton, promoted the expeditions of Davys, Hudson, and Button. The search for the north-west passage was the outcome of a great national effort in which colonizing companies and enthusiasts took part; but the north-westers devoted their attention to the land north of Newfoundland, 'the land that God allotted to Cain,' as Cartier described it ; and although Best's motto that 'no land is uninhabitable' may be true, this particular land was found unfit for serious colonization, so that the colonizing aspirations of the north-westers have been forgotten in the same way as the East Indian aspirations of the colonizers, whose quest led them to the south of Newfoundland, have been forgotten. Although the north-westers founded no colonies, they discovered Hudson Strait and Hudson Bay, and a new trade and industry. Thus Davys and Hudson foresaw the possibilities of the fur-trade, which in later days helped to keep Newfoundlanders in Newfoundland or Labrador after the fishing season was over; and Baffin advocated whaling in the northern seas, thus opening up a new industry on the east coast of Labrador, and, after Sir John Ross re-explored Baffin Bay (1818), on the coasts of the islands on the north of Labrador. But the fur-trade and the whaling industry were not what these men originally intended. Nor was the north-west passage effected until the search for it was resumed in 1819 , and crowned with success in 1906. However, these latter-day searchers, who almost 
proved the truth of Davys's motto that 'no sea is unnavigable, ${ }^{1}$ had nothing to do with Asiatic or any other trade or industry or colonization, and belong not to history but to geography.

French France, meanwhile, had entered the arena. Verrazzano, seekers after Asia tried to found Canada, a Florentine who had been in Cairo, resolved to find a western way to Cathay, and played in France the part which John Cabot had played in England. In ${ }_{5} 524$ he cruised along America northward from North Carolina, ${ }^{2}$ and annexed to France the territory which lay between New Spain and Newfoundland, and which was thenceforth called Norumbega or New France. He seemed to think that a western way would be found at or near the Hudson. ${ }^{3}$ One map ( $15^{27}$ ) represented New France as extending from Florida to New Hampshire, ${ }^{5}$ another confined it to the country between the Hudson and St. Lawrence. There was most admired disorder, which Sebastian Cabot did not diminish, when he declared that in his famous (or fabulous) voyage of discovery $(1498)$ he annexed to England all the coast between the latitude of the Chesapeake ${ }^{6}$ and the Arctic Circle. Portuguese claims to the New Land of the Cortereals or of Bacalhaos were flaunted by angry geographers, Spain showed that Florida might mean almost anything, and Labrador, Newfoundland, the land of Cortereal, Bacalhaos, Norumbega, New France, Florida, and New Spain chased one another across the map, as shadows chase one another across the earth on a day of mingled sunshine and cloud in spring.

which de- France followed up Verrazzano's expedition by sending sign encroached Jacques Cartier (I534) to seek Cathay by way of the St. upon Nerw- Lawrence. His landfall (1534) was Cape Bonavista in foundland, I534 et seq.,

Newfoundland, whence he steered north, and passed through Belle Isle Strait, from Quirpon to Blanc Sablon and Brest-

\footnotetext{
1 Hakluyt, Principal Navigations, vol. vii, pp. 249, 252.

${ }^{2}$ Lat. $34^{\circ}$. $\quad 3$ Lat. $40^{\circ}$.

${ }^{5}$ Lat. $43^{\circ}$.

- Lat. $38^{\circ}$. 
teaching map-makers for the first time that Newfoundland and Labrador were separate ${ }^{1}$ - skirted the west coast of Newfoundland from Point Rich to Cape St. George, and discovered the Magdalen Islands, which were teeming with walruses, Prince Edward Island, Bay Châleurs, and Anticosti. On a second voyage Cartier entered the Gulf by Belle Isle Strait (1535), and left it by Cabot Strait and St. Pierre Island-a route hitherto unknown to geographers, and found, or thought that he found, a route to Tartary, by the Saguenay, and the usual gold and rubies on these outskirts of Tartary. Cartier's (1540-1) and Roberval's (1542-3) colony or winter party of two hundred persons, 'as well men as women,' ${ }^{2}$ at or near Quebec, followed and failed. Cape Bonavista was Cartier's take-off, and St. John's Haven, Newfoundland, was Cartier's and Roberval's trysting-place, so that Newfoundland, which Englishmen regarded as inseparable from Labrador on its north, was regarded by Frenchmen as inseparable from Canada on its west. To the Englishmen, as to the Icelanders of old, Newfoundland was part of the Atlantic seaboard; to Frenchmen it was part of the Gulf, and the river of St. Lawrence. French ideas were incompatible with English ideas about Newfoundland. Nor was this the only danger to English interests in Newfoundland. The French announced their intention to act upon their ideas. When Roberval was in St. John's, he saw seventeen fishing-ships, and decided disputes betwcen French and Portuguese fishermen, and judges are often the preface to kings. Moreover, Roberval's commission specified 'Canada, Hochelaga, and other surrounding places' as his sphere of action, ${ }^{3}$ Charlevoix adding that 'Newfoundland, Labrador, and Baccalaos' were mentioned by name ; ${ }^{4}$ and a proviso in his commission, that

1 But see Hakluyt, Principal Navigations, vol. viii, p. I 88.

2 Ibid., vol. viii, p. 283 .

3 'Et aultres lieulx circonstacens.' Canada: Collection de Manuscrits, ed. by J. Blanchet, Quebec, I883, vol. i, p. 30 .

* Charlevoix, History of New France, translated and edited by J. G. Shea, New York, vol. i, p. $24^{2}$. 
land possessed by, and under subjection to allied potentates was to be respected, served as a warning, that, if Newfoundland were to be annexed by England, the deed must be done before it was too late. Frenchmen were not likely to stay their hands. Like Spain, France followed up American

but zuas as yet in an imperfect stage.
(2) There was an international fishery in Newfound land of English ships, I 502 ? et seq., exploration by immediate colonization. Spanish methods of colonization consisted of two stages : the first stage was to keep ajar the door of Asia, through which gold, silver, and spices were expected to flow; and the second was to keep in military and industrial subjection the American continent, from which these blessings actually did flow, by the same sort of feudal pressure as that which had been applied in Granada. French methods were an improved edition of Spanish methods, but Cartier and Roberval were still in the first stage, and wanted merely to hold by force the threshold of Tartary. The second stage began sixty years later.

The new French move instantly produced an English countermove, of which there were other predisposing and exciting causes. The chief predisposing cause was the growth of an international fishery in Newfoundland.

Cabot discovered an ideal annual trade-route to and from Newfoundland. Ships were wafted thither from the southwest of England and north-west of France by the east-wind, which was described as constantly blowing from February to May. Ocean currents were equally propitious. The nearest is not the straightest way to Newfoundland, for the earth is a sphere, but lies north of west; and when the ships neared the American shore the Arctic current, which sweeps down Davis Strait and chills the Atlantic sea-board of North America with an unnatural coldness, helped them to regain or cross the latitude from which they started. ${ }^{1}$ During September and October, before the harbours froze, the westwind wafted the wanderers homeward. What more could summer-fishermen desire? Possibly English ships fished ${ }^{1} 51^{\circ}$ lat., if from Bristol. 
and traded in Newfoundland every summer ever since $\mathbf{I}_{502}$; Rut $\left(\mathbf{r}_{527}\right.$ ) and Hore $\left(\mathbf{r}_{536)}\right.$ ) fished, and Rut sent letters home by two English trade-ships; two English Acts (I542, I548) exempted the Newfoundland fisheries from certain dues, fees, and prohibitions; and at that time fishing-fleets from the south-west of England went to and from Newfoundland with every spring and autumn, like the winds and ocean currents upon which they relied. Nor were they alone.

About $\mathbf{1 5 0 6}$ Jean Denys, of Harfleur, is said to have sailed of French to what he called Rognoust (Renewse), about fifty miles south of St. John's in Newfoundland, and a sailor of Dieppe ships, 1506 et seq., followed him in $\mathbf{1 5 0 8 .}{ }^{1}$ In $\mathbf{5} \mathbf{5} \mathbf{I}$ Breton pilots were in request in Spain, because they knew the way across the North Atlantic, and shortly afterwards Breton fishermen named Cape Breton. Rut $\left(\mathbf{r}_{\mathbf{5}} \mathbf{2 7}\right)$ found twelve Norman or Breton fishing-ships in St. John's; Cartier, when he threaded Belle Isle Strait (1534), found a ship of La Rochelle near 'the port of Brest', thirty miles or so west of Bradore Bay; and Brest, Belle Isle, and perhaps Quirpon ${ }^{2}$ are Breton names. Cartier found French fishing-ships at St. Pierre (1536); Roberval (1542) found a few French ships in St. John's, and Wyett (I594) fifty-two, or more, French ships in Placentia Bay. Haie wrote, but not from personal knowledge, of one hundred fishing-ships, many of which were French, upon the great misty submarine Bank of Newfoundland, one hundred miles east of St. John's; and Parkhurst $\left(\mathrm{I}_{578}\right.$ ) vaguely estimated the total French fleet in the waters of Newfoundland at $\mathbf{I}_{50}$ sail, against $\mathbf{2}_{20}$ to $\mathbf{r}_{30}$ Spanish, 50 Portuguese, and 50 English ships. But Parkhurst was one of those people who think in tens, and all his estimates, especially his estimates of the Spanish fishermen, were probably exaggerated.

1 Ramusio, Delle Navigationi, ed. ${ }_{15}^{6} 5$, vol. iii, p. 425 .

2 Or Carpunt. But Cartier wrote Rapont. See James P. Baxter, Memoir of Cartier, I906, p. $80 \mathrm{n}$. 
of Spanish along with French ships,

The Spaniards, who fished in these waters, were Basques from the Bay of Biscay, and, as there were French Basques from the border towns of St. Jean de Luz and Sibiburo, it is difficult to say whether most of those who were counted as Spániards were not really French, or were counted twice over. The Basques were the great, and at first the only hunters after whales and walruses in the Gulf of St. Lawrence, although they also fished for cod. They were numerous after Cartier's discovery of the walruses on the Magdalen Islands (1534); but had probably frequented these waters at least as early as $1530.1^{1}$ They were usually found in the company of French or Portuguese; thus, in 1583 , out of thirty-six ships at St. John's there were twenty Spanish and Portuguese ships; and ten years later, according to the accounts of English privateers, many Basque ships from France and Spain, and a few Breton ships were busily employed in catching cod, whale, and walrus on the south coasts of Newfoundland, and on the coasts of Cape Breton Island, in small scattered groups of two or four sail, and there was a large fleet of over sixty Basque ships in Placentia Bay, only eight of which were Spanish.

of Portu- The Portuguese also fished in company with other nations.

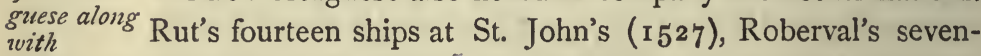
French and teen ships at St. John's ( I $_{542}$ ), Haie's one hundred ships on otherships; the Great Banks ( $\left.1_{5} 8_{3}\right)$ were partly Portuguese and partly French; and the twenty foreign ships in St. John's in 1583 were partly Spanish and partly Portuguese. ${ }^{2}$ The Portuguese were always ready to fraternize with their rivals, and, about I 550, turned swine and goats loose on Sablon Island, whereby Englishmen and Frenchmen in distress were refreshed in $\mathrm{I}_{58} 3$ and $\mathrm{I}_{598}$ respectively. Unlike the French and English, but like the Spaniards, they were never backed

1 C. Fernandez Duro, Disquisitiones Wauticas, Lib. VI, Arca de Noe, pp. 295, 3I $4,3 \mathrm{I} 5$.

2 Hakluyt, Principal Navigations, vol. viii, p. 82. 
by their country in these waters. Perhaps both Spain and Portugal were deterred from asserting themselves by the Treaty of Tordesillas, which might, for aught they knew, assign Newfoundland to the other Power. If so, this motive would be no longer operative after $\mathbf{r}_{580}$, when Portugal merged in Spain.

Thus four nations fished side by side in armed but their cusinnocent anarchy. Their customs were different but similar. ${ }^{\text {toms of the }}$ All the English ships hailed from the south-west of England, similar; and the proceeds of the cod-fishery used to be divided into equal thirds-one for the owner, one for the victualler, and one for the crew in lieu of wages. ${ }^{1}$ French crews, also, had a movable wage, if their ships caught less thản three hundred Quintals, ${ }^{2}$ and, as this maximum was rarely obtained, profit-sharing was the rule both among the French and the English fishermen. Both the English and the foreign fleets were subject to so-called admirals, who seized or allotted fishing-stations, and places for erecting temporary stages and flakes for drying cod-fish, and dispensed rude justice; but the English admiral of a harbour was the captain who first arrived there, while foreign captains as a rule succeeded one another as admirals by weekly rotation. The customs of the sea ensured some.sort of order, and there were signs of a tacit partition of spheres of influence.

The southern half of the west coast of Newfoundland was but their universally shunned, and two Basque whalers, which were fishing $_{\text {places }}$ wrecked in the Bay of St. George in I59I, were probably different, driven thither by storms. ${ }^{3}$ The most westerly fishing-stations Basques on the south coast, of which we hear from English sources, beingsouth, were first the Bay-possibly White Bear Bay-where a Placentia, French vessel saved Hore in $\mathbf{r}_{53}{ }^{6}$; next Little and Great

1 Calendar of State Papers, Colonial Series, America and West Indies, 1640, p. 315 ; Sept. 1, 1681 ; Nov. 18, 1698.

2 Quintal $=$ cwt. (circa).

3 Hakluyt, Principal Navigations, vol. viii, p. 163 (S. Wyet). 
St. Lawrence, at the foot of the promontory between Fortune and Placentia Bays (1597); then St. Pierre Island (I 594); then Placentia Bay, where the big Basque fleet assembled in r $_{594}$, and lastly Cape St. Mary, which divides Placentia from St. Mary's Bay ; and at all these stations no other ships except Basque or French ships were seen. This unwilling evidence by three or four isolated Englishmen as to French predominance on the south coast, and more especially in Placentia Bay, is only less remarkable than their eloquent silence as to the existence of any single Englishman in those parts. French influence was all in all on the south coast of Newfoundland, in the Magdalens, and St. Pierre, and on the west coast of Cape Breton Island; and the Spaniards, who were there, only sheltered themselves under the wing of their relations from the other side of the border.

Bretons, Ec., being at Brest and in Petit Nord,

The French ships concentrated not only in Placentia Bay, on the south coast of Newfoundland, but also at Brest, on the Labrador coast of Belle Isle Strait, which was described by Lewes Roberts as 'the chief town' of Labrador, ${ }^{1}$ but it was only a rendezvous for French fleets on their way to Canada, and for French fishermen, who, during the seventeenth century, sailed thence down the east coast of Newfoundland as far as White Bay, and down the west coast as far as the Bay of Islands, ${ }^{2}$ and called the land along which they coasted 'Le Petit Nord'. True, twelve (French ?) boats helped J. Knight's comrades near Fogo Island (1606); and Port à Port, which lies between the Bay of Islands and St. George Bay, was discovered long before $165^{\circ}$; but a casual glance at maps, which were drawn before $\mathrm{I} 768$, proves that very little can have been known by the fishermen of Belle Isle Strait of what lay between White Bay and Fogo on the east coast, or between the Bay of Islands and St. George Bay on the west coast.

1 Merchants Mappe of Commerce, I638, ed. I 700 , ch. xii, p. 54, misquoted by Prowse, Baxter, Robertson, Hind, \&c.

2 'Tres ilhas.' 
Before the close of the seventeenth century Ponchartrain in Bradore Bay was substituted for Brest as the rallying-place for the fishermen of Le Petit Nord and Belle Isle Strait. The Great Bank of Newfoundland may be described as a third French-or, rather, French-Portuguese-sphere, into which Englishmen did not intrude until the eighteenth century.

The two French coastal spheres impinged upon Indian (within the spheres of action. Indians had a village on St. George Bay region of in 1594, and haunted the shores of White Bear Bay (?) Beothics) $\left({ }_{53} 8\right)$ and Placentia Bay ( $\left.{ }_{594}\right)$, but it is not quite clear whether these Indians were Micmacs from the continent, or were the Beothics or native Indians of Newfoundland. The Beothics, according to Whitbourne ( 1618 ), were confined to the west shore, and to the east shore north of, and including Trinity Bay, but Whitbourne only knew the east shore at first hand. Probably the Beothics always had their homes inland by the great lakes and rivers-which no European knew of until late in the eighteenth century-and only visited the Bays in summer, in order to catch wingless auks and breeding birds, which covered every rocky islet 'thick as stones on a paved street', 'or grass on a field'.' We have no certain knowledge that these visits extended to the west and south shores. On the east coast these annual visitors served as a buffer state, which kept Englishmen and Frenchmen apart. There is no evidence that the Beothics were ever numerous or ever tamed. In 1597, 'three hundred savages' helped two hundred Frenchmen against an English privateer on the Magdalen Islands; and it is fairly certain that they were Micmacs imported for that purpose from the continent. Similar scattered references to Frenchmen and Indians hunting together on the south coasts of Newfoundland suggest the same explanation.

Trinity Bay must have been well known from early times,

1 Hakluyt, Principal Navigations, vol. viii, pp. I81, 192. The breeding birds included murres (LTria), razor-bills (Alca torda), \&c. 
the southeast being cosinopolitan,
St. John's being increasingly English, and Ferryland mostly English.

as Cartier recognized Bonavista Cape and Catalina Harbour, at its northern extremity, in 1534 ; and Purlican at its southern extremity was a fishing-resort in 1597 . Conception Bay was known even better than Trinity Bay, and being free from Beothics was far more popular. The ninety miles of coastline between Cape St. Francis, which is on the southernmost promontory of Conception Bay, and Cape Race, which is the southernmost cape on the east shore of Newfoundland, were best known and most popular. The Beothics were never tempted so far away from their lakes and rivers; harbours were deep and numerous, and their entrances were narrow; moreover the coast between Cape Race and Cape Francis lay nearest Europe. Sixteen of the thirty-six ships in St. John's in ${ }^{1} 5^{8} 3$ seem to have been English, and at that date no French ships are mentioned as being there. Yet in ${ }_{1527}$ and ${ }_{542}$ French ships were numerous in St. John's, and English ships were absent $\left(\mathbf{I}_{52} \mathbf{2}_{7}\right)$ or not mentioned (1542). In St. John's the French star was setting and the English star was rising, though as yet it was only one amongst many. Ferryland, where twenty-two English ships were seen in I594, and an English 'fishing admiral' held sway in I597, was probably an exclusive English port. Frenchmen and the Basque allies, who clung to their skirts, were unconsciously monopolizing Placentia Bay, Belle Isle Strait, and the neighbouring seas and shores, and were neglecting the cosmopolitan havens on the south-east. Englishmen left the south, north, north-east, and north-west coasts to the Frenchmen and the savages, and limited themselves to the strip of straight land, and many-dented bays and coves, in the south-east corner of the island, and more especially to those parts which were freest from savages. In doing so, they stamped an English character on Ferryland, as far as an English or any other character can be stamped on an island, where no white man ever built a house or stayed during a winter.

The Eng. Behind the fishers there was a great mass of public opinion. lish fisher. 
The twelve writers mentioned in the note ${ }^{1}$ were not, with men reprethe exception of Hagthorpe, colonial enthusiasts, but they sented a unanimously praised the Newfoundland fisheries for three was naval, reasons. First, 'the greatest jewel of this realm, and the chiefest strength and force of the same for defence and offence, is the multitude of ships and mariners', ${ }^{2}$ and 'it is the long voyages that increase and maintain great shipping'. ${ }^{3}$ Proclamations and Acts of Parliament, passed in $\mathbf{1}_{540} \mathbf{1}_{552}$, and 1562 , ordered fast-days to be kept, in order that fishing-fleets might grow in skill, size and number, for in those days fleets which fought were fleets which fished or traded, and, whenever war seemed imminent, there was a 'general arrest' or embargo on merchant-ships and sailors. The policy was justified by results. In the east of England, large ships belonged to big commercial companies, and fishing-ships were small and rarely went far; Frobisher's voyage from London to Hudson Strait in two barks of only 25 tons and 20 tons $\left(\mathrm{r}_{576}\right)$ being the exception which proved the rule. On the other hand, individuals living in the west of Europe

1 I. Captain R. Hitchcock, Pollitique Platt, written before ${ }^{1} 577$ (printed I 580), in Dr. Arber's English Garner, vol. ii, p. 144.

2. Dr. John Dee, General and Rare memorials... of Navigation, or The Brytish Monarchie, 1577 .

3. E. Jeninges, Brief Discovery of the Damages that happen to this realme by disordered and unlarefull diet, 1593 .

4. J. Keymor, Observations on the Dutch Fishing, 16o1 ; Observations touching. Trade and Commerce with the Hollander (wrongly attributed to Sir W. Ralegh).

5. Tobias Gentleman, England's Way to win Wealth, ... by building. . . busses, Ec., $16 \mathrm{I}_{4}$.

6. J. R., Trade's Increase, 1615, pp. 13, 26.

7. E. S., Britaines Busse, I615.

8. T. Mun, Discourse of Trade, $162 \mathrm{I}, \mathrm{p} .57$.

9. E. Misselden, Free Trade, 1622, p. 35 .

I0. J. Hagthorpe, England's Exchequer, or a Discourse of the Sea and Navigation, with some things thereto coincident concerning Plantations, 1625.

II. H. Robinson, England's safety in Trade's Increase, 164r.

12. Lewes Roberts, Treasure of Trafficke, I64I, p. 59.

2 Sir G. Peckham, in Hakluyt's Principal Navigations, vol. viii, p. IIO.

3 Sir H. Gilbert, in Hakluyt's Principal Navigations, vol. vii, p. 185. 
were in the constant habit of making long fishing voyages, and in 1578 their ships which fished in Newfoundland averaged $5^{2}$ tons apiece. ${ }^{1}$ The model herring buss proposed by Hitchcock was 70 tons.

commercial (Secondly, the fishing politicians were also trading politicians, in a way, and pointed out that the fish which were caught were sold in Spain and other parts, and the sellers brought back gold and silver from Newfoundland, as though it were a modern Colchis. ${ }^{2}$ The fishery in Newfoundland was an industry which created trade, and, although Englishmen of that date did not think that all trade was good, they were quite sure that that trade, which exported non-English products, and imported gold and silver, was good for England.

andphilan- Thirdly, it was an age of social unrest, of which the increase thropic. of pasture-lands and enclosures, of townsmen and craftless men, and of vagabonds, paupers, and criminals, were symptoms rather than causes. Many remedies were applied:- for instance, in 1547 and 1572 magistrates were ordered to set vagabonds and paupers to work; but on what? Oceanfishery provided a ready answer; and Hitchcock's ideal buss carried one captain, twelve sailors, and twelve beggars. Apprenticeship to the new industry was prescribed as a safe cure for pauperism, and the fishing and trading politicians were also social philanthropists.

(3) Idealistic colonizers represented a cult wider and

From the twelve apostles of fishing to the advocates of colonial expansion, it was only a step, but a long step. The seventeen representatives of the colonial school whose names are mentioned below* repeated everything that the representa-

1 Hakluyt, Principal Navigations, vol. vii, pp. 278-9; vol. viii, pp. IO, II.

2 E. Haie's letter, Dec. 7, I6I I, in the Calendar of State Papers, Carew MSS.

* I. Sir H. Gilbert, Discourse to prove a passage by the North-west to Cathaia and the East Indies, written 1574, published in Hakluyt's Principal Navigations, vol. vii, p. I 58, I 576.

2. R. Hakluyt, Notes ... given ... to Frobisher, I 578 ; ib. p. 244.

3. Sir G. Peckham, Western Planting, in Hakluyt's Principal Navigations, vol. viii, p. $89,15^{8} 3$. 
tives of the fishing school had urged, but they also uttered deeper than distinctive notes of their own, none of which could have been uttered by mere advocates of distant fishing, and some of the fishing which ring across the centuries with a strangely modern sound. Thus pauperism and crime were indirectly ${ }^{4}$ or directly attributed to 'superabounding multitudes', ${ }^{16}$ 'superfluous numbers',"1 'general populousness',14 'overflowing multitudes', ${ }^{16}$ and 'the o'erpeopled kingdom' ${ }^{15}$ The people swarmed 'as young bees in a hive in June', and the 'mightier thrust the weaker out ', ${ }^{6.14}$ so that colonization was like a fact of natural history. England was 'full' and must be 'disburthened' ${ }^{10.16}$ so that colonization was a social duty. Elsewhere, 'Ireland was crying for colonists and the solitudes of Virginia for inhabitants,' ${ }^{13}$ and 'God did create land to the end that it should by culture yield things necessary for man's life'. 'Transmigration' 'by coloni' who 'have need of a

4. C. Carleill, Brief Discourse upon the intended voyage to the hithermost parts of America, ib., p. I34, I583.

5. Sir W. Ralegh, Letters passim, in E. Edwards's Life of Ralegh, 2 vols., ob. 16 8 .

6. W. Symonds, Sermon, cited in Edw. D. Neill, English Colonization of America, pp. 28-3x, 1609 .

7. Capt. John Smith, Description of Nerw England, in Dr. Arber, English Scholars' Library, vol. xvi, I616. 1620.

8. Sir R. Whitbourne, Discourse and Discovery of Nerefoundland,

9. Short Discourse of the Nervfoundland, dedicated to Lord Falkland, 1623 . 3624 .

I0. Sir W. Alexander, Earl of Stirling, Encouragement to Colonies,

II. Virginia's Verger, in Purchas, Pilgrims, vol. xix, p. 218, 1625.

I 2. Sir R. Gordon, of Lochinvar, Encouragements for... Undertakers .... in Cape Briton, 1625.

13. Lord Bacon, Essay on Plantations, 1625, and see S. R. Gardiner, History of England, 1603-42, vol. i, p. 333 note.

14. Sir W. Vaughan, Golden Fleece transplanted from Cambrioll Colchos, by Orpheus junior, 1626 .

15. R. Hayman, Quodlibets lately come over from New Britaniola Old Nerwfoundland, 1628.

16. Rev. John White (?), Planters Plea, 16 60.

17. Sir Ferdinando Gorges, Letters passim. See Prince Society Publications, Boston, U. S., 1890: Sir F. Gorges, a vols., ed. by J. P. Baxter. 
country to inhabit' into 'a country' which 'hath need of a colony to cultivate it' 11 was necessary: a sentiment which looks like a nineteenth-century appeal to physical law. Who should go? The simplest and crudest answer was that paupers and criminals should go. Frobisher (I577) and Ralegh (I6I 7) sailed, as Cabot sailed or asked to sail (I 598), with condemned men, and Gilbert ( $5_{5}{ }^{3}$ ) with pirates. Paupers figured in many schemes, ${ }^{\mathbf{1 . 3 4 . 7 . 8}}$ Captain John Smith suggesting $^{7}$ that parish orphans should be apprenticed, Whitbourne ${ }^{8}$ that each county should send out an annual cargo of 'able subjects', and appoint an agent in the colony to transmit their wages to the parishes concerned, in order to defray the costs which had been incurred; and their suggestions were only meant to enforce Sir John Popham's Act of I697, which banished vagabonds 'into such part beyond the seas as shall be at any time hereafter for that purpose assigned by the Privy Council'. Gordon's saying, 'Better a plantation than a debtor's prison,' ${ }^{12}$ sounds like a prophecy of Georgia. But what was written must be read with care. The writers often meant, not that actual criminals and paupers, but that the causes of possible future crime and pauperism should be removed; thus Sir Ferdinando Gorges wrote that discharged soldiers were likely to become pirates or mercenaries unless they became emigrants. ${ }^{17}$ Religion, too, was a crime; Peckham, Baltimore, Arundel, and probably Northampton, were Papists, John White was a Puritan, and when Hakluyt described colonies as 'a place of safety if change of religion or civil war should happen in this realm', ${ }^{2}$ he touched the noblest of all incentives to colonization. Many, too, denounced the wickedness of making colonies 'emunctories or sinks', 13.15.16 and in Hayman's verses-' When you do see an idle lewd young man You say he's fit for our plantation, I say such men as you are far more fit'-the sentiment almost atones for the poetry. ${ }^{15}$ John White wrote, 'A colony is a part and ${ }^{1-17}$ For references see pages $3^{2-3}$. 
member of her own mother's body. I deny that such as are gone out from the State are cut off from the State. The roots that issue out from the trunk of the tree though they be dispersed yet they are not severed, but do good offices by drawing nourishment to the main body'; and Ralegh's belief, 'I shall yet live to see it (Virginia)an English nation' (August 2 I, r602), showed that Ralegh as well as White held ideals of colonization which are only beginning to revive in our own day.

To descend from these lofty heights, trade, too, was an in- whose centive. By trade men meant gold, silver, and spices; but a very commercial little experience taught them to substitute the three F's-fish, only growfirs, and furs-for the three vanities. Experience too taught ing into them larger views of wealth, and we read in Purchas that 'that then is the richest land which can feed most men'."1 The north-west passage, which successive colonizers found at or near Saguenay River, Chesapeake Bay, Hudson River, Kennebec River, and a Canadian lake 'believed to be salt at the other end and lead to the Gulf of California', ${ }^{10}$ faded further and further into the background or towards the North Pole. The north-westers went one way and the colonizers another, although it must not be forgotten that both drank at the same fountain-head, and that splendid visions of India and Cathay floated before the eyes of all the founders of all the early American colonies. Indeed, the historian is more and more surprised at the quickness with which so persistent and universal a delusion was dispelled or lost its power to mislead. Conquest and conversion belonged also and whose to the order of vanishing ideas, and self-defence took their military place. The first effort to colonize Newfoundland was due to still dethe necessity for self-defence; but in the sixteenth century structive as men did not draw nice distinctions between self-defence and defensive. counter-attack. Indeed the distinction now drawn between offensive and defensive war would have been an anachronism in the Elizabethan age. The Spanish monopoly of the sea south of the latitude of the Azores produced during the reign of 
Elizabeth a state of war between Spain and England, and war was waged without having been declared. Most of the English warriors were from the south-west of England. Sir John Hawkins, Sir Francis Drake and his cousin Sir Barnard Drake, Sir Walter Ralegh-who said 'To break peace where there is no peace it cannot be ', ${ }^{1}$ and acted on what he said-and Ralegh's half-brother Sir Humphrey Gilbert, were Devonshire men; Sir Richard Grenville and probably Christopher Carleill-who was son-in-law of the most anti-Spanish minister of the time, Sir Francis Walsingham, and had himself fought against Spain in the Low Countries-were Cornishmen. By a strange irony of fate the English fishermen, who fished in perfect peace, year by year, side by side with the Spaniards in Newfoundland as though war were impossible, also came from the south-west of England.

Gilbert's plans embodied these In ${ }_{574}$ Gilbert, Carleill, and Grenville joined with Peckmixed ideals, I 574, I 577, ham in a petition for a patent to colonize 'the northern parts of America' and $f_{I, 000}$ was raised in Bristol for the purpose. The matter dropped, but was revived in 1577 , when Gilbert forwarded to Lord Burleigh a plan to annoy the King of Spain by granting him a patent to discover and inhabit strange lands. The patent was to be 'a mere cloak for the rain ', shrouded in which he was to sail first to Newfoundland and seize the Spanish, and perhaps the Portuguese merchant-ships and sailors while a-fishing, and afterwards to a West Indian island and seize gold and silver. Then at last England would be safe, and perhaps succeed to the Spanish and Portuguese monopoly of the ocean. 'Leagues and fair words' were mere 'mermaids songs, sweet poisons or macquesites', and must be set at naught; or the Queen should punish and profit by her subjects who set them at naught. It was 'more than time to pare their nails by the stumps that are most ready pressed to pluck the Crown'

1 William Stebbing, Life of Ralegh, 1891, p. $3^{27}$. 
from the Queen's head; and what must be done must be done quickly for the " wings of Man's life are plumed with the feathers of death'.' Seven months later Sir H. Gilbert received so did his (a patent to discover, inhabit, build on, fortify, own and rule atent, (subject to the Crown and to the Crown's claim to one-fifth ${ }^{578}$, of gold and silver) lands not possessed by friendly Christian powers. His settlements were to be made within six years; and in accordance with the petition of $x_{574}$ no settlement might be made within two hundred leagues thereof without his licence. He had power to make laws, and acts of selfdefence were authorized; but acts of 'unjust or unlawful hostility' would be punished by restitution or outlawry,a clear reference to the aggressive proposal of the preceding year. The present journey was referred to as a 'journey for discovery', and there is a mysterious reference to a future 'journey for conquest'. ${ }^{2}$

' The first attempt by our nation to plant', as Haie calls it,", and rewas made by $\operatorname{Sir} H$. Gilbert in $\mathbf{r}_{578}$, and involved a short ${ }_{a \text { voyage, }}^{\text {sulted in }}$ sea-trip, 'the loss of a tall ship,' and an ignominious return ${ }^{1578}$, home, and men were 'sorry that so forward a mind hath so backward a success'." The proposal of 1577 was in binary and the form like a sonata, and implied a northern settlement in or division of near Newfoundland and a southern settlement in or near the into a West Indies; and Sir H. Gilbert soon assigned the projected and southnorthern settlement to partners, reserving the projected ern plan. southern settlement to himself. But the partners, who were to start first, did nothing. In $1_{583}$ he prepared a scheme under which, if adventurers assisted immigrants, they should be given land by way of bounty, and, if England assisted immigrants, its costs should be repaid by the immigrants or the colony. In the same year he sold some of his rights to

1 State Papers, Elizabeth, Domestic Series, vol. cxviii, No. I 2.

${ }^{2}$ Hakluyt, Principal Navigations, vol. viii, pp. 17, 20.

${ }^{3}$ E. Haie, Report of the Voyage by Sir HI. Gilbert. Hakluyt, Principal Navigations, vol. viii, p. 34.

4 Historical MSS. Commission, Hatfield MSS., Oct. 17, 1578 . 
Sir George Peckham, who petilioned the Government for permisssion to take out 'recusants of ability', promising in return that one-tenth of his immigrants should consist of destitute persons. ${ }^{1}$

The In $\mathrm{I}_{58}{ }_{3}$, thanks to Peckham, Ralegh, Thomas Aldworth, Annexa-
tion of St. Richard Hakluyt, the merchants of Bristol (who gave ' $I, 000$ John's in marks and upwards '), Walsingham and Walsingham's last 1583, real- new son-in-law Sir Philip Sidney, Sir Humphrey completed
ized the northern his preparations and set sail in June from Plymouth with five plan, ships, the Ralegh (200 tons), - which was equipped by Sir W. Ralegh, and for some reason or other returned home after two days' sail, - the Delight (1 20 tons); the Golden Hinde (40 tons), the Swallow (40 tons), whose crew was recruited from pirates, and the Squirrel (10 tons). After the Ralegh returned, the ships averaged $5^{2}$ tons apiece, which was the exact average tonnage of the Newfoundland fleets of that period. ${ }^{2}$ The crew consisted of 260 men, including artisans and miners and those who returned in the Ralegh. It being late in the year, the intending colonists sailed first to Newfoundland, 'which was but 700 leagues from our English coast' 3-Cabot's exact estimate-and where they were sure to obtain supplies. The Swallow and Squirrel parted from their comrades on the way, and the crew of the Swallow boarded a French vessel, helped themselves to clothes, tackle, and victuals, with an expedition perfected by long practice, after which they were upset in their own boat and saved from a watery grave 'by those silly souls whom they had before spoiled'. The four vessels reassembled outside St. John's Harbour, which they entered, not without accident. Inside the harbour they found sixteen British and twenty Portuguese and Spanish vessels. Gilbert then took possession of 'St. John's and two hundred leagues every way' with the usual feudal solemnities, enacted that public

1 Calendar of State Papers, Col. Ser. Add., I 574-1674, pp. 8-1 3.

2 Ante, 1). 32.

3 Ante, p. 13 . 
worship should only be solemnized according to the rites of the English Church, and that treason and misprision of treason should be punished according to English law. Two hundred leagues would include the whole of Newfoundland, the Great Bank of Newfoundland, and Cape Breton Island, besides sections of Labrador and Nova Scotia. Then he taxed, or in other words commandeered, supplies and services from the fishermen in the neighbourhood, granting them in return their drying-places on the shore in fee farm, and 'was most curious in the search of metals'. The fishermen had made Newfoundland into a free West-European market, and Haie wrote, "We were supplied of our wants commodiously as if we had been in a country or some city, populous and plentiful of all things.' Despite their sumptuous and cheap fare, some of Gilbert's sailors stole a ship and sailed away, others ran away into the woods, and others falling sick were sent home in the Swallow, so that the overloaded and undermanned Delight, Golden Hinde, and Squirrel alone remained. The Governor, after seventeen days' rule, sailed but it endaway on August 20, bag and baggage, with all his ships and all ed quickly, his men, and without leaving any one or anything behind to represent him or to enforce his laws. He put his 'small artillery' into the tiny Squirrel and sailed in it himself. $\mathrm{He}$ intended to found a southern settlement, but the Delight was wrecked off Sable Island, owing to his command to its pilot to steer west-north-west contrary to the pilot's judgement. Sir Humphrey's miners and minerals, the pirate crew which had formerly been in the Swallow, and many stores went down in the Delight; consequently his comrades urged Sir Humphrey to go home, and he consented, declaring that they would all return 'royally in the Spring', that the officers of the Golden Hinde should found the southern settlement, and that he would confine himself to St. John's, which 'had won his heart from the south'. The weather was stormy, and he disastrouswas entreated to transfer himself to the Golden Hinde, but ly, 
replied, 'I will not forsake my little company going homeward, with whom I have passed so many storms and perils.' The storm grew worse and worse, but above the storm Sir Humphrey's voice was heard ever and anon crying out aloud with accents of joy, 'We are as near to heaven by sea as by land.' Night fell, and the lights of the Squirrel suddenly went out. That is all. Of Sir Humphrey we feel inclined to say as his step-brother said of himself, "What matter how the head lie and herc- if the heart be right?' A halo of real heroism illumines this ically. foolish founder of the greatest colonial empire in the world, and where a hero leads, even though it be to ruin, others are apt to follow with enthusiasm, for tragedies such as these attract by their dignity more than they deter.

B. Drake's expedition to Nervfoundland revived tice destructive side of the Northern plan, $\mathrm{x}_{5}{ }^{5}$

The story of Sir Humphrey Gilbert's great colonial effort had two sequels, one in Newfoundland, and one in the southern settlement, which he had always contemplated. Spain was more and more menacing. In 1580 she had absorbed Portugal, so that the Treaty of Tordesillas was more likely to instigate than to restrain a Spanish attack on Newfoundland; and in the same year Spanish ships seized an English fishing-ship returning to Newhaven from Newfoundland. ${ }^{1}$ In $5^{8} 4$ the Spanish ambassador was dismissed from London. In 1585 the King of Spain seized English ships and sailors in Spain under pretext of a 'general arrest', and the sailors were imprisoned and underwent 'unsufferable' treatment. Immediately Sir Francis Walsingham revived Sir Humphrey Gilbert's project of $\mathbf{I} 577$, so far as it related to Newfoundland, although he knew that it meant war, ${ }^{2}$ and Sir Walter Ralegh, the then Vice-Admiral of the western counties, was directed to send ships from his vice-admiralty 'for the intercepting of such of the King of Spain's subjects as should repair to the fishing at Newfoundland'. Ralegh set the press-gang to work and supplied a vessel of his own,

1 Calendar State Papers, Carew MSS., Oct. 18, I580.

2 State Papers, Elizabeth, Domestic Series, vol. clxxvii, No. 58 . 
and Sir Barnard Drake sailed with the flotilla to Newfoundland. 'A good number of Spanish vessels' were 'taken at the said fishing' and six hundred Spaniards.' Portuguese prizes and prisoners were also taken, and the stench of the Portuguese prisoners killed Sir B. Drake, a judge or two, and eleven jurymen, which casts a lurid light on prison horrors in those days. In 1588 the invasion of England by the Spanish Armada, which had been mooted twenty years previously, at last took place. The Queen's ships numbered 34 and their tonnage averaged 185 tons; the English merchantmen which fought under the Lord High Admiral, Sir F. Drake, Sir R. Grenville, Sir J. Hawkins, and Sir M. Frobisher, numbered ${ }_{148}$, and their tonnage averaged 57 tons. Of the Spanish ships, which were 128 in number and averaged 230 tons, onehalf were lost. The naval power of Spain was broken.

A few lonely English ships strayed for the first time into so did the Gulf of St. Lawrence (I 593-7). Charles Leigh, a founder privateers of Guiana, who in 1597 commanded two of these ships, of St. dreamed vaguely of colonizing the Magdalens, and of ex- Lavorence, cluding other nations-especially the French Basques-from the Gulf, and from the south coast of Newfoundland; otherwise the sole object was to attack Spaniards, nor was that object successful. Basques were still in evidence, but wereor persuaded the English that they were-French subjects from Bayonne, St. Jean de Luz, and Sibiburo. In I594 Sir W. Ralegh wrote to the acting Secretary of State that Spanish ships were in the Channel, and that it was 'likely' that all our Newfoundland men will be taken up by them if they be not speedily driven from the coast, for in the beginning of August our Newland fleet are expected which are above one hundred sail. If those should be lost it would be the greatest blow that ever was given to England '. ${ }^{2}$ The danger passed, and in 1604 there was peace with Spain. After 1604 Spain

1 State Papers, Elizabeth, Domestic Series, vol. clxxxiii, No. 13.

2 July 20, I 59t. E. Edwards, Life of Sir W. K'alegh, vol. ii, p. 95. 
and Portugal ceased to play a part in the political history of Newfoundland. Sir H. Gilbert's proposal of 1577 , Sir F. Walsingham's proposal of ${ }^{1} 5^{8} 5$, and Sir B. Drake's exploits in ${ }_{5} 55$ are vivid reminders that the attempted colonization of Newfoundland in ${ }^{58} 3$ was an incident in the AngloSpanish war, that its emblem was a sword rather than a plough, and that it was intended to destroy Spaniards as well as to provide new homes and industries for Englishmen.

Virginia realized the constructive side of the southern plan, I $5^{8}$,

The second part-or, if we include the voyages of Frobisher and his successors, the third part-of Sir Humphrey Gilbert's plan was to create a new colony on the southern coast of Northern America, and the execution of this design fell to Ralegh, whose patent ( ${ }_{5} 584$ ) was copied from Gilbert's patent. He, too, or at all events Sir R. Grenville and R. Lane, who led the colony, regarded it as a base for attacking but it was the West Indies. The colony, which was named Virginia, not permanent, and the ideal behind both plans was imperfect. was planted with far greater care than Gilbert's colony ( $15^{84}$ ), lasted fitfully for three years or so, and flickered out. Large creative ideals, the usual delusions about Cathay, gold, and silver, and a desire to retaliate against Spain, inspired both Ralegh's and Gilbert's efforts; and after their failures the history of colonization turned over a new leaf; there were no more colonies founded in anger, the old delusions about Cathay and gold and silver melted into thin air, and the large Elizabethan ideals were accompanied by small projects, which after a time dimmed and obscured them. The turning-point was the close of the sixteenth century. 


\section{Authorities}

There are not yet any authorities which deal with the colony, or with colonization, exclusively; but colonization is still part of the naval, commercial, or industrial history of the country concerned. The three countries most concerned are England, Spain, and France.

William L. Clowes, The Royal Navy, A History, 7 vols., 1897 et seq.

C. Fernandez Duro, Disquisitiones Nauticas, 6 vols., 1876-81, and other works by him.

R. Hakluyt, Principal Navigations, vols. vii and viii, of the edition of 1904 .

Calendars of State Papers: Colonial Series, America and West Indies, 1574 to 1700 ; Domestic Series; Carew MSS. These Calendars are invaluable, and where I quote from them reference to the originals. is unnecessary; in cases where such reference is advisable I quote from the originals direct.

Professor W. Cunningham, Growth of English Industry and Commerce, 1892 .

Charles Leigh (ante p. 41) wrote, Oct. 4, 1597, A brieffe platforme ffor a voyadge with three ships unto the Iland of Ramea, Br. Mus., Add. MSS., I 4027 , fol. 289 , in which he proposed next year to sail to the Magdalens, 30 days before the French, to garrison a port there, to 'forbid the Frenchmen from the trade of fishing in that place who this last year by force (as having first possession of the harbours) did expel myself and others her Highness's subjects from the said island.' Some of his crew were to remain and 'betake themselves to tillage planting and building' and the rest were to fish, and while returning homeward to search the harbours of Cape Breton Island and of the south coast of Newfoundland, and to drive away 'such ships of Bayonne, St. Jean de Luz, and Ciborrow (sic) in France which are apparently known every year from these parts to serve the King of Spain with fish', thus crippling the King of Spain, ' who were not able to maintain his ships at sea if he were not supported by these fishermen'. His ideas of ruling the Gnlf, of colonizing the Magdalens-at a time when no French or English colonies existed in North America--and of striking first at the French Basques, as though Spain depended upon them, were unique and did not bear fruit.

The Plan of Sir H. Gilbert to annoy the King of Spain, 1577 , ante p. 36, Sir F. Walsingham's Project, I585, ante p. 40, an account of Sir B. Drake's expedition, ${ }_{5} 5_{5}$, ante p. $4 \mathrm{I}$, and Charles Leigh's proposal to colonize the Magdalens, ante p. $4 \mathrm{I}$, are given respectively in Appendices $\mathrm{A}, \mathrm{B}, \mathrm{C}$, and $\mathrm{D}$ to this book, pp. 242-50. 


\section{AVALON PENINSULA}

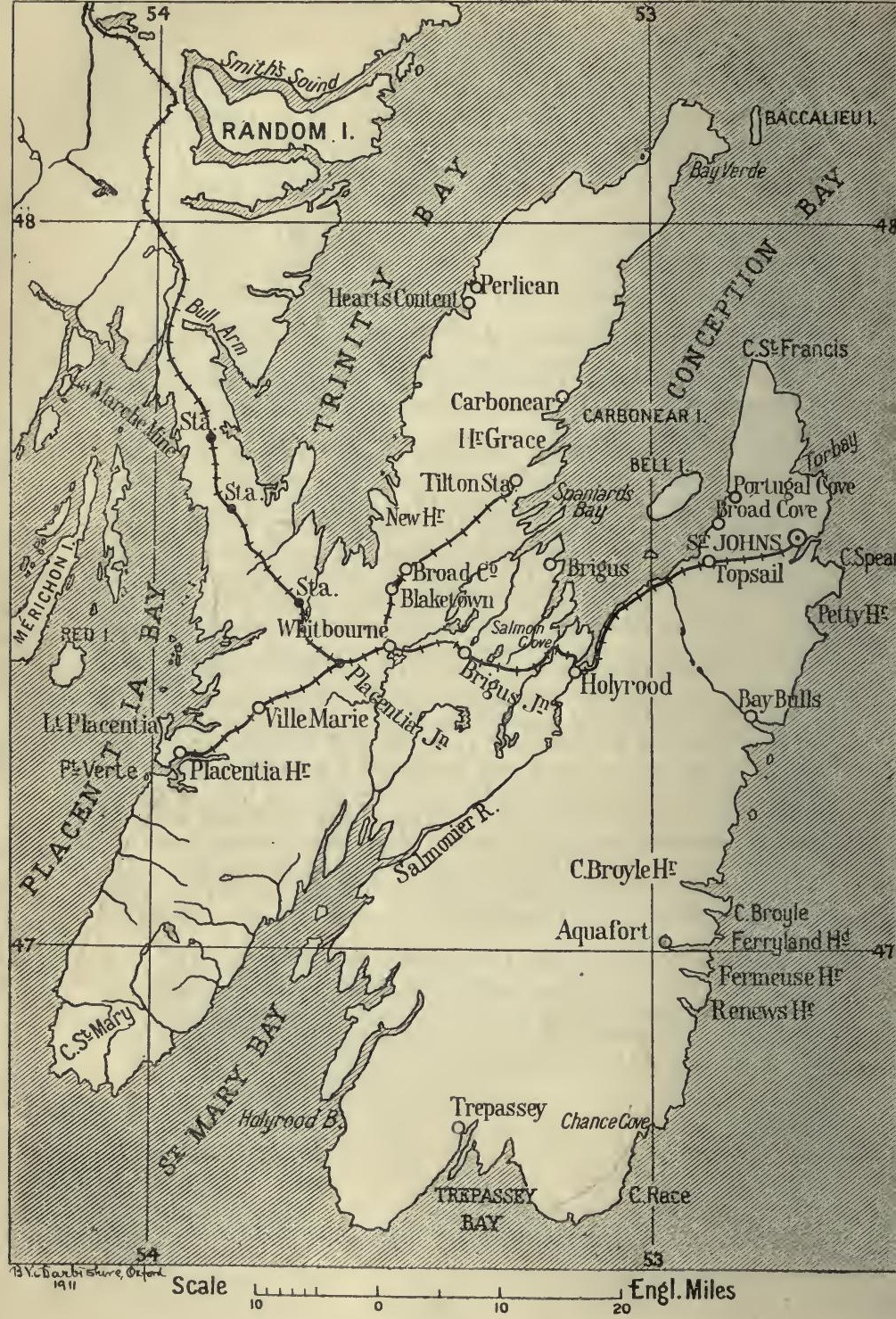




\section{CHAPTER III}

\section{THE FIRST BEGINNINGS OF A PERFECT ENGLISH COLONY IN NEWFOUNDLAND}

THE colonial impulse towards North-east America came The second over England in two waves. What Frobisher, Gilbert, and period of Ralegh tried to do, belonged to the first broken wave; tion was a Gilbert's doings shining like foam upon its crest, 'one ${ }_{1600 \text { et seq. }}^{\text {period, }}$ moment white, then gone for ever.' Nor is the wave intelligible, unless we look beneath it at the Western Powers of Europe solidifying into nationhood, and at the friction, fret, and ferment, which accompanied the process. The second wave, which swept across the Atlantic in the early seventeenth century, resembled the first wave in its origin and nature, but was less stormy, and bore along with it a different group of men, animated by a different set of ideas, and adopting different methods. It, too, was a single wave, and the recolonization of Virginia and Newfoundland, and the actual or attempted colonization of New England and New Scotland, were parts of one policy which must be studied as a whole.

In passing from the sixteenth to the seventeenth century we pass from an age of great men and little Companies to an age of little men and great Companies. The incorporation of the East India Company on December 3 I, I600, laid the foundation-stone of our Indian Empire, and amongst other things stimulated the growth of the Royal Navy. Long voyages still meant big ships and skilful sailors, and the East India Company began to construct 1,100-ton ships which were as big as the biggest Queen's vessels, and were nearly three times as big as the biggest merchantmen, which fought Spain in 1588 . The standard of size changed, and fishingships became of little use for purposes of serious war. Even

(1) of great Companies, and great ships (hence the Royal Navy), 
the huge East Indiamen went too far away to be of much use in case of European war. ${ }^{1}$ The need for creating a strong Royal Navy to defend the shores and ships of England was imperative. Charles I and Cromwell addressed themselves to this task with equal vigour, and convoys, which had been demanded for (not by) the fishermen of Newfoundland ever since 1620 , and had been partially conceded in 1623 and 1629 , began to act regularly as their guardian angels during the Commonwealth and the Restoration.

the Com-

panies

And it was an age when the east and west of England being East- begran to oppose one another, and a little rift appeared English or which widened into the Great Rebellion. Symptoms of this
WestEnglish; opposition were seen in the constitution of commercial Companies, which were composed either of Londoners or of merchants in the south-west of England, or of both; but, if they tried to include both, they usually failed or changed into the one or the other. Conversely there was a tendency for the east of England to trade in one direction, and for the west of England to trade in a different direction. As early as $\mathbf{I}_{52} \mathrm{I}^{2}$ Cardinal Wolsey tried to unite London with Bristol in an expedition to Newfoundland, but without success. Those London adventurers and East-English sea-captains, who initiated the attempt to sail to India both by the north-west and by the north-east, soon limited themselves to the north-east, out of which there arose trade, but it was only trade between London and Russia. The Guinea Company ( 1588 ), in which Exeter and London took part, was succeeded in 16 I 8 by an African Company composed of Londoners only. 'The title of the first East Indian Company was 'The Governor and Company of merchants of London trading to the East Indies', and its nature answered to its name. Of the northwesters ${ }^{3}$ Captain Davys relied solely on Exeter, Bristol, and the south-west, and Davys's successors on London, until

$$
\begin{aligned}
& 1 \text { J. R., Trade's Increase, } \\
& 2 \text { Ante, p. 19. }
\end{aligned}
$$


Bristol once more sent forth Captain James as a counterblast to Captain Fox, whose expedition was equipped by Londoners in the same year ( $\left.16_{3} \mathrm{I}\right)$.

Colonization also fell into the hands of commercial thus the Companies, which showed a similar division of England into East-Enga south-eastern and a south-western half. In 1606 a double ginia ComCompany was formed, the London branch of which was to pany meant Company was south, Bristol branch of which was to occupy a northern settlement in West-EngNorth America, or what was then called 'Virginia.' The ginia Com. southern border of 'Virginia' wass $34^{9}$ N. lat., which was also pany meant the southern border of the land which Verrazzano purported to $i n$ to annex to France, and its northern border was originally America, $45^{\circ} \mathrm{N}$. lat. The settlements were to be coastal settlements situated one hundred miles from one another, and extending one hundred miles inland and one hundred miles out to sea. ${ }^{1}$ This dualism was derived from Sir H. Gilbert's scheme for a northern and southern settlement; and it seemed as though America were destined to reproduce English dualism, its northern coasts being reserved for West-English, and its southern coasts for East-English settlers.

Shortly before the Virginian patent was granted, but this Bartholomew Gosnold sailed from Falmouth at the expense plan broke of Sir W. Ralegh ( $\mathbf{6} 602$ ), Martin Pring from Bristol at $162 \mathrm{r}$, and the expense of Bristol merchants (1603), and George dualism Weymouth on behalf of the Papist Earl of Arundel (1605)-- multiplex; who played a part towards the western branch of the Company like that played by Sir G. Peckham towards Sir H. Gilbert-in order to prospect the projected northern settlement, which was afterwards called New England. In 1607 a pure West-English colony was established at Monhegan Island, off the coast of Maine, by Captain George Popham, brother of Sir John Popham, a Somersetshire man, and by Ralegh Gilbert, Sir Humphrey's youngest son. It

1 Purchas, Pilgrims, vol. xviii, p. 399. 
failed, and the southern settlement, which afterwards monopolized the title of Virginia, succeeded. New efforts were made to colonize New England by Sir Ferdinando Gorges, who was a kinsman of Sir W. Ralegh and a Somersetshire man. Then this artificial symmetry broke down. In I62 I New Scotland was detached from what was then regarded as New England, and was vested in Sir William Alexander, and its colonists, if any, were Scotch. In the same year the region dedicated by statesmen to West Englanders, mixed perhaps with a few hunted Papists, was occupied by the Pilgrim Fathers, who were uncompromising Puritans from East England. The colonization of North America (I607-2 I) was meant to go two ways-West Englanders to the north and East Englanders to the south, and began to go many ways, one of which was the very opposite of what was intended. The colonizing instinct proved too complex to flow in its two appointed artificial channels.

(2) of $a$

European dread of underpopulation, so that permanent colonization by good citizensivas dis. couraged;

While clear geographical plans were becoming confused and improved, confused ideas about colonization were becoming defined and degraded. Bodin and Sully were Frenchmen, but their theory that men were the only strength and source of wealth, and that want of men was the chief danger to a state, began to infect English philosophers. It is hardly too much to say that the word 'over-population' disappeared from English literature from ${ }^{\prime} 630$ to 1798 . Not over-population but depopulation was the statesman's bugbear; and both theorists and statesmen unanimously condemned the export of good citizens, except for definite military commercial or philanthropic necessities. Thus the charter of Virginia was revoked by the first Stuarts, because the realm was being depopulated $;^{1}$ and writers of that time approved only of the export of 'all the beggars ..., all delinquents for matters which deserve not hanging, to the plantations'?

${ }^{1}$ John Doyle, The English in America, I882, p. $24 \mathrm{r}$.

2 H. Robinson, England's Safety in Trade's Encrease, 1641. 
Under Cromwell it was proposed to colonize the Pacific with indentured vagrants and felons, who, when their indentures expired, were to receive small grants of land. ${ }^{1}$ Under Charles II, Sir J. Keyling, C.J., made this policy of punishment and reformation habitual, while Samuel Fortrey, John Pollexfen, and Sir Josiah Child popularized and exaggerated the theories of Bodin and Sully. Bad men were sent out, not out of cynical levity, but in obedience to a fixed idea, which pervaded France and Germany as well as England, that good men could not be spared, that change of air was good for moral invalids, and that Europe suffered from anaemia, and must be purged but not bled. On the American continent there was a demand for resident labourers, which sometimes succeeded in making English practice contradict English theory. In Newfoundland there was no such demand until the eighteenth century, and economic law did not thwart the dreams and designs of philosophers and politicians. On the other hand, temporary fishermen in Newfoundland often became permanent citizens in New England, so that Newfoundland became the half-open door through which labourers emigrated to America, and the joint needs of Newfoundland and America set legislative restrictions at defiance.

Colonization belongs not merely to commerce and to (3) of theories of population, but to national politics. The duel Anglobetween England and Spain was over. Between Englishmen rivalry. and Dutchmen an industrial competition began to prevail, which at times resembled, or even degenerated into war. But Anglo-French rivalry in colonial and commercial expansion proved persistent, insistent, and internecine, and was ever present to the imagination both of English and of French colonizers in North-east America.

In the first chapter of the history of colonization in North- France east America, France was first in the field, and its designs aiming at

1 Br. Mus., Egerton MSS. 2395, fol. 202.

voL. V. PT. IV 
land, and preceding England in Nova Scotia,

(where England attacked her)

and England aiming at Nova Scotia

were vast enough to include Newfoundland. ${ }^{1}$ The second chapter opened in $1598,{ }^{2}$ or eight years before the date of the Virginia Company. France was again in the wan; and in 1603 De Mons received a new patent under which land was assigned to him between $40^{\circ} \mathrm{N}$. lat., which is south of New York, and $46^{\circ} \mathrm{N}$. lat., which is south of Newfoundland, and north of the limits of the first Virginian patent, but his trading monopoly and jurisdiction extended to $54^{\circ} \mathrm{N}$. lat. ${ }^{3}$ and no western limits were named. Under this patent Acadia was colonized. Immediately Samuel Argall swooped down from Virginia upon the colonists of Acadia, and all but annihilated them $\left(\mathrm{I}_{6} \mathrm{I}_{3}\right)$, and the torch of border warfare, which Argall lit, was not put out until the Treaty of Paris (1763). From time to time treaties were made confirming existing possessions, but both sides claimed constructive as well as actual possessions, and claims were invented in order to challenge or overreach rival claims. Thus soon after I 603, when De Mons's limits were defined, New England was enlarged on the north from lat. $45^{\circ}$ to lat. $48^{\circ}$, overlapping not only De Mons's colony but Newfoundland, and on the west to the Pacific. There was an inextricable medley of interlacing and coinciding claims. In 1627 De Mons's former dominions were transferred along with Canada to Richelieu's hundred Associates, and Florida (which is south of Virginia), the Arctic Circle, Newfoundland, and a 'fresh sea', which was believed to lead to the Gulf of California, became the boundaries of New France. The fresh sea, and apparently Newfoundland, or such parts of it as were not already possessed by friendly powers, were included. In I663-4 Colbert's Company of the West took over the task of Richelieu's hundred Associates, and amongst other places Canada and Newfoundland were specified as

\footnotetext{
Ante, p. 22. $\quad 2$ Canada, vol. v, pt. i of this series, p. 39.

s Charlevoix, History of New France, transl. by J. G. Shea, vol. i, p. 247 .
} 
under their control. No part of Newfoundland was ever and preannexed, occupied, garrisoned, or governed by France until ceding the Restoration. The French colonization of Newfoundland Nerufoundbegan in 1662 , or half a century after the permanent land; colonization of Newfoundland by the English was an accomplished act.

The French motive in colonizing Newfoundland or its south coast was officially described as 'fear of being forestalled by the English ', and Anglo-French rivalry was the French as well as the British incentive to expansion.

The colonial methods and aims of France were similar to French those which actuated the best class of Spaniards after the ideas differexcitement of their first discoveries had worn off; but French English aims displayed a definiteness and lucidity characteristic of ${ }^{\text {ideas, }}$ their race. They held fast to Bodin and Sully, who taught that men meant wealth and strength ; and, as in England, this axiom was deemed inapplicable to bad Frenchmen. La Roche, Roberval, and De Mons were authorized to take 'vagrant idle persons and masterless' and 'them that be condemned to perpetual banishment or for three years out of our realm' " ; and Colbert told his first 'Intendant' that the King held it unwise to dispeople France in order to people Canada, ${ }^{3}$ all of which ideas became characteristic British ideas in the seventeenth and eighteenth centuries. On the other hand, the French differed from the English policy of that period in three respects. First, Huguenots, although bad Frenchmen in the eyes of men like Richelieu, were not allowed to emigrate. Secondly, soldier settlers, although good Frenchmen, were encouraged to emigrate for military reasons; thus De Mons was enjoined to 'establish garrisons

1 Charlevoix, History of New France, transl. by J. G. Shea, vol. iii, p. 147.

2 Lescarbot, Histoire de la Nouvelle France, ed. I866, p. 413; Canada, Documents, 1883, vol. i, pp. 4I-2; H. P. Biggar, Early Trading Companies of New France, I gor, p. 40.

3 Canada, Documcnts, 1883 , vol. i, p. $18 \mathrm{I}$. 
and soldiers', 1 and Colbert planted old soldiers on the Richelieu. Thirdly, limited or temporary emigration was regarded as necessary to start the colony; thus Richelieu's hundred Associates were ordered to send four thousand French men and women to Canada in fifteen years, and artisans were induced to emigrate, but also to return, by making them masters at home after six years' service in the colony. ${ }^{2}$ As in Spain, residence in a colony was regarded as a privilege, was sometimes allowed for a term, was often refused, and was regulated with watchful jealousy in the supposed interests of the parent state. Indeed, great pains were taken to select soldier artisans as well as civilian artisans for colonial service. ${ }^{3}$

chiefly because their plans were and remained single,

The French aim was to found one great dominion like our Indian Empire, but with a small sprinkling of Frenchmen, who were to constitute the ruling classes. Their aim was single, and their dominion was to spread from ocean to ocean, for their plans were laid out on a continental scale, and it was clear that they would prevent, if they could, the British lion from lying across the entrance of the great avenue of approach to their dominion. Newfoundland was the lodge-gate of Canada, and must not be left in the hands of a possible enemy.

while Eng- The English plan was dual, and the French plan was lish plans single. Englishmen abandoned their dual plan, and Frenchand became men pursued their single plan. The English colonies manifold. developed upon infinitely divergent and unexpected lines, and had separate histories; while French colonial history was-like its policy-one, unchanging, and predetermined. The rich disorderly vitality of the English colonists presented a strange contrast with the thin monotony of the vast French colony of Canada.

1 Lescarbot, op. cit., I609, Livre IV, ch. i ; ed. 1866, p. 4I 3.

2 Canada :- Documents, \&oc., vol. i, p. 69, article xiii.

3 Sec e. g. Ordre du Roi, Jan. 5, 1697; MS. copy in the Archives of the Dominion of Canada of the French Records. 
It was in the midst of this conflict of ideas, tendencies, Nerufoundcolonies, and nations, that the new birth of the English colony permanentof Newfoundland took place. It was a product of the same ly recreatideas; some of its godfathers, notably Sir J. Popham, were ed, I6ro, the same as those of its sister colonies; its re-birth and their birth or re-birth occurred at the same time; the same brief effort was made to combine Londoners and Westerners in one company; and Anglo-French rivalry was an ever-present source of dread or spur to action.

Newfoundland differed from its sister colonies in the small- by westness of its stature, in its tendency to become for a century or Englishmore a preserve for men from the south-west of England- and by in spite of appeals to Scotland, Wales, and Ireland, and to fishermen Papists-in its comparative freedom from the felon's taint, in non-coloits remoteness from the scene of war (at all events before 1662 nizing and after 1713 ), and, above all, in the secular strife which (raged between disciples of the fishing and colonial schools nd their respective representatives-the fishermen who came and went each year, and the settlers, who, by the irony of fate, were also fishermen, and depended for recruits on those with whom they strove. This strife began in $16 \mathrm{I}$, and went on indecisively for two centuries or so. Accordingly, (being soon after its re-birth, the English colony of Newfoundland ${ }_{a}^{\text {therefore }}$ began to go on its own insular way almost unaffected by its apart) continental neighbours on the south; or, to borrow a classic simile, the Newfoundlanders began to dwell, as it were, in a cave of their own, and turned their faces towards the inner wall, on which they only saw from time to time the shadows of the actors in the great real world passing and repassing. Not but what they had some rude awakenings.

There is a State paper of almost the same date as the although charter of the East India Company, in which the colonization of Newfoundland was advocated for purposes of trade, and, ed the of course, of the North-west Passage, but the King as well as fusual inthe traders and the poor (but 'not the impotent poor') must 
which have bear a share in it, as it might incite French, or possibly described, Spanish jealousy. ${ }^{1}$ With the change of century Spain had been deposed from, and France had been promoted into the position of arch-rival.

A little later, Virginia and Maine were colonized, and while colonists were on their way to Virginia and Maine ( 1607 ) Sir J. Popham, who had promoted both movements, initiated a third movement, and wrote to the merchant adventurers of Bristol urging them to recolonize Newfoundland. In reply, the merchants asked for royal support, which was promised. Then they subscribed funds, and John Guy, one of the subscribers, wrote a pamphlet in favour of the scheme. On April 27, I6ro, the King incorporated them under the title (of 'The Treasurer and the Company of Adventurers and Planters of the city of London and Bristol for the Colony was nomi- or Plantations in Newfoundland.' ${ }^{2}$ As in the Virginian nally dual, Company of 1606 , London and the West of England were yoked together; and, as in the Virginian Company, the first names of members were names of statesmen. Two of these names were significant-Henry Earl of Northampton, a reputed Roman Catholic, and the great Sir Francis Bacon, who wrote that 'it is a shameful and unblessed thing to take the scum of people and wicked condemned men to be the people with whom you plant's Next on the list was Thomas Aldworth, perhaps the same ' $T$. Aldworth Mayor of Bristol' who promoted Sir H. Gilbert's expedition of I583. John Guy and his brother Philip, both of Bristol, J. Slaney and H. Slaney, both of London, were the only others of the forty-six members who afterwards became had an famous in connexion with Newfoundland. The colony,

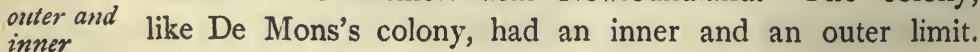
limit, like De Mons,

1 State Papers, Colonial Series, vol. i, No. 9, an unsigned, undated copy, with corrections by Sir E. Conway, endorsed 'Plantacion in America', Calendared? I600 given in Appendix E, pp. 250-3.

2 Purchas, Pilgrims, vol. xix, p. 406.

3 Essay on Plantations, 1625. 
The inner limits were described by a line of longitude drawn north from Cape St. Mary, and by a line of latitude drawn west from Cape Bonavista. Everything to the east and south of these lines belonged to the Company. The east coast of Placentia Bay and the south coast of Bonavista Bay were included in the inner limits, and formed an integral part of the essential colony. In a larger and vaguer sense the the outer colony was defined as co-extensive with 'all those countries, limitsbeing lands, and ilands commonly called Newfound land', and lying French, in between $46^{\circ} \mathrm{N}$. lat. and $52^{\circ} \mathrm{N}$. lat. The southern outer limit a sense, was De Mons's northern territorial limit; the northern outer limit trenched on Labrador, and the two outer limits included both sides of Belle Isle Strait on the north, and both sides of Cabot Strait on the south, so that the colonists might, if they could, close the two main ways into the Gulf of St. Lawrence. In that sense the patent was anti-French; in other respects it was purely peaceful in character. The patentees were also given mining rights on ungranted parts of the adjacent mainland. The kernel of the colony was a little larger than the peninsula of Avalon, and its husk was a little larger than the island of Newfoundland. Fishing rights and rights incidental and the thereto, whether of Englishmen or foreigners, were not to be $\frac{\text { patent }}{\text { being sub- }}$. affected by the new patent; and sea and shore were still to ject to fishbe free to fishers of every race. The reservation both of sea ing rights. and shore expressed what Grotius in his Mare Liberum $(1609)$ laid down as a rule of international law-that free sea-fishing was a natural right, and that fishing was not free, if fishers might not land and dry their nets, and build and occupy temporary buildings on the shore. ${ }^{1}$ Grotius's rule has long ago been qualified by the rule, which makes the sea within three miles of the shore the exclusive property of the nation which owns the shore. But perhaps the authors of the patent thought less of Grotius's obsolete law than of the many thousand Portuguese, Spanish, French, and English

${ }^{1}$ Grotius, Mare Liberum, 1609, p. 22. 
fishermen, who had used these seas, coasts, and shores, for a century, and would be unlikely to submit without a struggle to the new yoke. Moreover, colonists were hard to find, and would probably be far too few and feeble to impose the yoke by force. They straggled in by forties at a time.

Guy found- Alderman John Guy, the first Governor, set sail in r6ro ed the first colony at Cuper's Cove, I6IoI 5 , with instructions to trade with the fishermen for dry fish and wine, and to settle in Conception Bay or elsewhere. ${ }^{1}$ Accordingly he chose Cuper's Cove (Port de Grave), on the west coast of Conception Bay, as his capital; and shortly afterwards $^{2}$ a sub-settlement, called Bristol's Hope, was formed at Harbour Grace, a few miles to the north. Guy, says Sir W. Vaughan, was 'the first Christian that planted and wintered in that island', and a letter from Guy to his employers (I6II) informs us that the colonists spent their first winter in building an enclosure 120 feet by 90 feet, and within the enclosure, a storehouse, dwelling-house, and workhouse, and a platform for three cannon. A boat was built, skins and furs were cured, sawpits and smiths' forges were used, corn was sown in spring, and the goats, pigs, and swine survived the ordeal of a winter which was mild. Of the thirty-nine human inhabitants who wintered there, four died, one of whom 'died of thought, having slain a man in Rochester, which was the cause that he came this voyage'; so that they were not quite all West-countrymen, nor quite so guileless as Bacon wished them to be.

and issued ( In August I6r I, Guy issued ordinances fining subject and fishing regulations, 1611 , which were repeated, foreign fishermen for throwing ballast into harbours, destroyng fishing-stages and cook-rooms, taking up too much space on the shore, defacing boat-marks, stealing boats, firing I62I, Es., fwoods, or spiriting settlers away. Accused of these seven

${ }_{1}$ Br. Mus. Cotton MSS. Otho E. VIII. 3; Prowse, History of Nervfoundland, p. 94 .

2 Eight years, Sir R. Whitbourne; one year, Bacqueville de la Potherie, Hist. de l'Amérique Septentrionale, I 72 I-2, vol. i, pp. 44-5. 
sins, the fishermen retaliated by inveighing against the sins of and were the settlers, which were three in number: seizing as they did the best fishing-places, stealing what fishers left behind, and prituries. forbidding bait-birds to be slain on Baccalieu Island ( 16 r 8 ). Orders were issued, probably by the Star Chamber, not to commit these sins (I62 I), ${ }^{1}$ but the fishing-captains ignored the Orders and defied the Ordinances, and these accusations and counter-accusations were bandied to and fro for the next century or two. Between August I6 I I and June I6 I2, Guy was in England, and William Colston, who bore a name honoured in Bristol, acted as Governor. On his return with settlers, cattle, and, as Protestant chaplain, Erasmus Stourton (1612), Guy sent Colston home for a holiday, and stood impotently by, while Captain Peter Easton, a pirate, commandeered men, arms, and provisions from the fishermen, and made Ferryland his rendezvous. The next winter, we are told, was severe; beer froze, and 'men 'drank half water, an ill remedy for cold'. The Irish cattle did badly. The party numbered sixty-two and 'a lusty boy' was born. Trinity $\mathrm{Bay}^{2}$ was visited, where Guy trucked with the Beothic natives, giving bread, beer, and brandy, in exchange for skins and furs. Next year a fisherman fired on the Beothics and scared them away from Trinity Bay, even as they had already been scared away from other coasts. For many years to come they were numerous in the bays north of Trinity Bay, where they caught auks and other birds while breeding on bare rocky islets, and terrified English colonists and fishermen on their south, and French fishermen on their north. Guy spent six summers, but only two winters, ${ }^{3}$ in Newfoundland, and

1 Docquet, Oct. 27, 1621. 'Also to Sir F. Gorges and other Commissioners for establishing of orders amongst the fishermen of Newfoundland .... to report unto them the orders here inclosed. Procured by Sir William Alexander.' I cannot find the enclosed orders.

2 Savage and Allhallows Harbours.

3 Orpheus junior (Sir W. Vaughan), Golden Fleece, I626, Part III ch. iv, p. 27 . 
in 1615 followed Colston, leaving these scenes for a brief career of slippered ease and civic honour in Bristol.

Mason Guy's successor, Captain John Mason, R.N. 1615-21, succeeded Guy, 1615- was co-founder with Sir F. Gorges of New Hampshire and 2I, Maine, had no ties with the west of England, was neither Papist, Puritan, nor trader ; spent six winters in his government, was a vigorous explorer, traded or tried to trade with Indians, wrote a pamphlet on Newfoundland (which appealed to Scotchmen and was published in Scotland), drew a map of Newfoundland (which was published in two pamphlets by Sir W. Vaughan), ${ }^{1}$ and encouraged the growth of corn to such an extent, that the rye-crops of Bristol's Hope were the cynosure of rival settlements. One incident made his rule memorable helped Ti- outside Newfoundland. Tisquantum, an Indian from New squantum, England, was rescued from Spanish slavery by a Newfoundland ship, was taken to Mason, with whom his friend Thomas Dermer of Virginia was staying, and was then sent by Mason and taken by Dermer to Sir F. Gorges, who restored him in time for him to act as interpreter for the Pilgrim Fathers. Mason's lot was cast in troubled waters.

and zuas Easton had his successors in Sir Henry Manwaring and opposed by
pirates and Ralegh's 'erring captains', who called at Newfoundland on

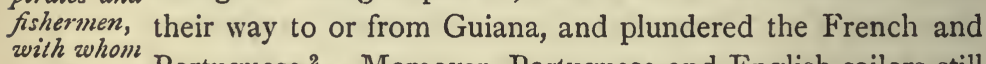
Whitbourne dealt. Portuguese. ${ }^{2} \quad$ Moreover, Portuguese and English sailors still frequented Petty Harbour and St. John's Harbour and fought with one another. So Sir Richard Whitbourne, a sea-captain of Exmouth, who for thirty-six years had fished off the coasts of Newfoundland, was sent out in $\mathbf{r}^{6} \mathbf{1 5}$ as a Commissioner to inquire into these disorders, and into those disputes between English settlers and English fishers, which were destined to prove interminable and irreconcilable. There were, says Whitbourne, about 250 English fishing-ships, consequently the inquiries had to be prosecuted at sundry times and in

1 Cambrensium Caroleia, 1625, and Golden Fleece, 1626.

2 Captains Woollaston, Collins, and Whitney? 
divers places, which did not suit the fishermen-who did not always attend. Further, Mr. Commissioner Whitbourne was unpaid, except by the fines which he levied, so that it was his delight as well as his duty to fine the absentees; and his mission did not throw oil on the troubled waters. Therefore Then the Mason's rule was not profitable, and the merchants, 'acquainted colony zeas with more speedy gain,' became impatient, and 'concluded to into divide the land into several shares', ${ }^{1}$ which the allottees resold. The colony from time to time shed portions of itself, division led to sub-division, and new characters appeared upon the scene.

In the first place Guy's settlement shrivelled into a tongue (I) a Harof land between three bays-Conception Bay, Trinity Bay, bour Grace and Placentia Bay. R. Hayman, of Devonshire and Lincoln's under Inn, who succeeded Mason as Governor of this reduced Hayman, territory, made Harbour Grace instead of Cuper's Cove his capital, called Newfoundland Britaniola with one ' $n$ ' and one ' $t$ ', and having, as he naively said, nothing to do except to oversee the work of other people, wrote poetry $\left(I_{62}{ }_{1-27}\right)$. His poems were entitled 'Quodlibets lately come over from New Britaniola old Newfoundland . . composed at Harbour Grace ... by R. H., sometime Governor of the plantation there, 1628 ,' in which he celebrated in limping lines the vices of Papists and Puritans, the virtues of settlers like E. Payne, Rowley, and Poyntz, the patriotism of colonizers like Vaughan, Falkland, Baltimore, and Mason, and the dishonesty of the agents, who failed to make the patriotism of their employers pay. He claims to have spent one winter only in Newfoundland, and almost every summer down to the end of his government ${ }^{2}$; but we do not hear that he made the patriotism of his employers pay. There were no resident Governors of Guy's settlement after Hayman; and in 1628 John Slaney-

1 Egerton MSS. 254I, fol. 166.

2 Ibid., fol. 162-9. Down to 1630 , if the endorsed date, which is not in the same handwriting as the documents, is correct. The documents are undated copies. 
the original treasurer of the Company of $1610-$ was regarded as 'the Governor of the whole land', ex officio, but, so far as is known, Slaney was never further west of London than Shropshire.

(2) Vaughan's subcolony near Trepassey, Ec., under Whitbourne, 1616 ;

The second fragment of the original block fell to the lot of a Welsh bard; and it too chipped itself into smaller fragments. In $1616 \mathrm{Sir}$ W. Vaughan, a Welshman who wrote prosaic poems and poetic prose, bought the land which lay south of the latitude of Petty Harbour, and dispatched colonists in I6I7 and 16r8. The second batch was taken out by Sir R. Whitbourne, who became Governor of Vaughan's colony, wrote $A$ Discourse of Nerefoundland $(\mathbf{1} 620)$ in praise of colonization, and prided himself (1626) on having made three colonizing expeditions thither. ${ }^{1}$ He was one of the very few fishers who crossed over to the settlers' party, and doubtless the events of $1_{615}$ had something to do with his conversion. Mason's map placed Vaughan's head-quarters at Trepassey (which he called Cambrioll Colchos), a cove south of Renewse (which he called Vaughan's Cove), and a spot between Renewse and Aquafort (which he called Golden Grove), all of which are in the south-east corner of the southeast peninsula of 'Britannioll ' (with two ' $n$ 's' and two 'l's'), as he called Newfoundland. Whitbourne resided little, if at all, in his government; and Hayman says that Vaughan was intending to visit his province for the first time in $16_{3} 0$, a previously intended visit having been apparently prevented by illness. Vaughan's colony soon shrank into its shell near Trepassey, or merged itself in the sub-colonies of South Falkland and Avalon, which were carved out of it.

(3) Falk- Thirdly, Henry Cary Lord Falkland, who came from an land's subcolony near old Devonian stock, and, like Sir H. Gilbert, Sir J. Popham, Renezuse, Sir F. Bacon, and other famous colonizers, took a practical 1623 ? interest in the internal colonization of Ireland, bought a strip lying between a headland south of Renewse and a headland 
south of Aquafort, on the east coast, and running due west to Placentia Bay, called it South Falkland, appointed a London agent named Wellsted to collect recruits, and either directed R. Whitbourne to convey them thither, or else took over some of Vaughan's and Whitbourne's emigrants, who were already there. ${ }^{1}$ He also bought from Guy the promon-(4) and in tory between Bonavista Bay and Trinity Bay, and named it North Falkland. He did not visit his purchases, but a book Trinity Bay; advocating colonization in Newfoundland was published for him in Dublin and appealed to Irishmen (r623), and he sent out some colonists, of whom R. Hayman sang, ' I joyed when you sent people to that land, I grieved when I saw all that great charge lost,' if this could be called singing. North Falkland, the fourth colonial division, was colonized, if at all, by residents in South Falkland.

Fifthly, George Calvert Lord Baltimore-who, like Peck- (5) Lord ham, Arundel, and probably Lord Northampton, was a Baltimore's Roman Catholic-bought a block of land, bounded by South at FerryFalkland on the south, and on the north by a line drawn from land, under the middle of Petty Harbour to Salmon Cove (Conception himself, Bay), and thence due west to Placentia Bay, ${ }^{2}$ and named his Aston, ${ }_{\text {Hill, }}$ sc., province Avalon, after Avalon in Somersetshire. In 1621 a 1621 ; Welshman, Captain E. Wynne, arrived as resident Governor $\left(\right.$ r62 I $\left.^{-5}\right)$ and made Ferryland his capital. Before Christmas a spacious house of timber with some stonework-like Guy's house-was built within a quoit's throw from the shore. A forge, salt-work, wharf, brewhouse, and enclosed paddock or garden for ' wheat, barley, oats, pease, and beans', were soon added. Next spring Captain Powell arrived with supplies and more settlers-some of whom were probably parish orphans, for in August he wrote home asking that no more 'boys nor girls nor any other persons not brought up to

1 State Papers, Colonial Series, 1574-1600, Nov. 10, 1626. Whitbourne writes as though he served Falkland, and never served Vaughan.

2 The patent of Apr. 7, 1623, is in Sloane MSS. 170. There was an earlier patent in 1622 . 
labour', but that a convenient number of West-country labourers should be sent out. The settlers, who were staying, numbered thirty-four. They supplemented salt of their own make with purchases, obviously from the French or Portuguese, at Fermeuse and Renewse. One of them announced that he had actually drunk water and 'it did quench my thirst as well as any beer'. In $\mathbf{I}_{62} 4$ Sir W. Alexander praised the 'horses, kowes, and other bestial ', 1 and the industry of these colonists. In 1625 Lord Baltimore hired one ship to transport cattle, and another ship to transport himself to Newfoundland, but there was a general arrest and the visit was postponed. In 1627 Sir A. Aston succeeded Captain Wynne as Governor, and Lord Baltimore paid his first visit. In 1628 Lord Baltimore paid a second visit with forty Papists, including his wife, sons, daughters, and sons-in-law, and two Romish priests. To E. Stourton's horror the priests actually celebrated mass. Ecclesiastical squabbles arose ; Lord Baltimore banished Stourton, the priests went, and there was neither Popish, Puritan, nor any other minister of religion in Newfoundland for the next seventy years (1628-97). A rude echo of the great world invaded his political as well as his religious repose. The French and English were at war in Europe and America, at La Rochelle, Tadoussac, and Quebec ; and three French privateers, manned with ' $\mathrm{La}$ fleur de la jeunesse de Normandye', made a raid near Cape Broyle, which Lord Baltimore repelled, rescuing several English ships. Then Lord Baltimore made a counter-raid near Trepassey, resulting in the capture of six French fishing-vessels ( 1628$)$, and the grateful English Government loaned one of the prizes as a privateer to Lord Baltimore's son for a year. The climate proved too cold, and his house became a winter hospital. Fifty out of a hundred colonists were sick at a time, so he asked for a colony further south for himself and

1 Prince Society, Boston: Sir W. Alexander, by E. F. Slafter, I 873 , p. 187 . 
forty followers. The King replied that the climate was not too cold, but that Lord Baltimore was too soft, and had better come home. But he had already flitted to the sunny south with his faithful forty, and there they founded Maryland. Those who remained behind were governed first by Sir A. Aston, then by W. Hill $\left(1_{6} 3^{2-8}\right)-$ so, at least, Lord Baltimore's son and heir averred. ${ }^{1}$

Sixthly, in 1622 Sir W. Alexander sent some Scotch (6) an uncolonists to Nova Scotia, but they wintered at St. John's, governed where one of them found, or thought that he found a silver- at St. mine, and all, or nearly all took service with the fishermen John's, who arrived in the succeeding spring. In 1623 Lord Baltimore's patent referred to a 'colonia' or 'plantation' of St. John's, occupying the eastern horn of Conception Bay, and having as its base a line drawn from Salmon Cove (Conception Bay) to the middle of Petty Harbour, and as its apex Cape St. Francis. In 1627-8 nine twelfth shares in this colony were, with the sanction of 'John Slaney, governor', offered for sale to Lord Conway. A prominent member of Slaney's Company, named W. Payne, was at that date allottee of 'the lot of St. John's', which he described as 'the principal, prime, and chief lot in all the whole country', 'and as it now stands, the ice being broken and some houses already built, it will require no great charge to follow it.' The silver-mine, and a chance that the holder of most shares would, if J. Slaney permitted, be 'president of that lot', were held out as additional inducements, ${ }^{2}$ but Lord Conway rejected these appeals to his cupidity and ambition. There are no earlier contemporary references to a colony of St. John's; and Whitbourne's, Vaughan's, and Alexander's exhaustive lists of Newfoundland colonies (1620) do not include a colony at St. John's. On the other hand, St. John's Harbour

1 Br. Mus. Egerton MSS. 2395, fol. 310.

2 State Papers, Car. I, Domestic Series, vol. lxxxiv, No. 13; vol. cviii, Nos. 37,6 r. 
all which were separate and lined the east coasts of Avalon

was still the fisherman's chief summer resort; there Sir W. Alexander's colonists were enticed away, and there Portuguese and English fishermen fought. ${ }^{1}$ Probably St. John's was the last settlement, because it was the foremost fishing-ground and mart, and colonists avoided it for fear that English fishers would absorb them, foreign fishers resist them, and both displant them. Sir H. Gilbert wished to dominate the international situation, and he went straight to St. John's. Merchants like Guy wished for trade, not politics, so that they hid themselves in safe, secluded corners. Lord Baltimore, who went nearest to the focus of strife, fell amongst enemies; but he too yearned for peace, and left Ferryland to his successors.

A glance at the map will show that the inner colony of I6ro was nominally full. There was North Falkland Colony between Trinity and Bonavista Bays; Cuper's Cove or Harbour Grace Colony between Trinity and Conception Bays ; St. John's Colony between Conception Bay and Petty Harbour; Lord Baltimore's colony between Petty Harbour and a headland between Fermeuse and Aquafort; South Falkland Colony between this headland and a headland south of Renewse, and, south of South Falkland, Vaughan's colony at Trepassey. Each of these six little colonies, except St. John's, extended to a meridian which lay west of the east coast of Placentia Bay. How far these settlements were effectual can only be inferred from evidence later than $\mathbf{r 6 6 2}$, when French rivalry stimulated men's memories or imaginations. Even then no English settlement on the east or any other coast of Placentia Bay was ever alleged to have existed, except one recent plantation by a man named Isaac Dethick, and we only hear of one Irish (?) settler in St. Mary Bay, which lies between Trepassey and Placentia Bay. On the other hand, the side of Newfoundland which was turned to Europe was very much alive and very English, so that foreigners were scarcely seen between Trepassey (whence

$$
1 \text { Ante, p. } 58 .
$$



Lord Baltimore expelled the French), Cape Race, and Cape Bonavista. They were crowded out. The method of occupying a little port here and a little port there, and of leaving the natural capital to take care of itself, came instinctively to seafarers from the numberless little ports of Devonshire and Cornwall, and was perhaps also due to the rarity of ready-made clearances on the shores of this 'land of hills and woods'.1 Nomadic fishermen had cut down or burned trees near the shore; the pioneers apparently expected to find, and found around their first homes some three or four acres of cleared land for their gardens and crops; but all of them noted as something exceptional a few hundred acres of natural pasture land at Trinity Harbour, Verde Bay, Renewse, Cape Race, and Trepassey. ${ }^{2}$ As a rule rocks, firs, pines, and birch trees seem to have come close to the shores, on which fishermen dried their fish, and to have made it difficult to pass from cove to cove. Whatever its cause may have been, this tendency to dispersion succeeded so far as the fretted eastern fringe of Guy's inner colony was concerned. It is true that there was a plethora of poetry, and that Mason, Falkland, Whitbourne, Vaughan, and Hayman wrote books which are of more importance to historians than to history, and that the silent colonizers, Baltimore, Guy, and Wynne did most; it is true, too, that the idea of planting Scotch, Irish, Welsh, and West-country folk in several centres was never translated into practice; but, after all, these six small colonies without a capital made Trepassey, Conception, and Trinity Bays, and all that lay between them, very English.

We had almost forgotten the seventh sister-colony which (7) And Sir W. Alexander bought from the patentees of 1610, and Sir W. Sir W. Alexander bought from the patentees of 1610 , and Alexwhich extended beyond the confines of Guy's inner colony ander's from Placentia Bay to the Gulf of St. Lawrence. ${ }^{3}$ Sir W. nominal

1 Hakluyt, Principal Navigations, vol. viii, p. 82. sub-colony out west.

2 Purchas, Pilgrims, vol. xix, pp. 4I 4 , 43I, 447, \&c.

3 Publications of Prince Society, Boston: Sir W. Alexander, by E. F. Slafter, 1873 , p. 188 
Nerw fishing rules, issued in 1634, wire called the Western Charter.

Alexander was a poet, like Vaughan and Hayman; and, like his poetry, his colony in Newfoundland existed only in his flimsy imagination. It belonged to the class of colonies which were never colonized. The seventh sister was a fable and a dream.

It seemed as though all the six settlements were on their way to rejoin the seventh settlement in the moon of Ariosto, where unfulfilled desires meet 'what is lost through fault or chance or time', when the Star Chamber re-edited the Order of $1621,{ }^{1}$ and issued in 1634 new rules, some of which forbad any one to commit what I have called the seven sins of the fishermen and the three sins of the settlers. ${ }^{2}$. These ten sins were re-grouped under eight heads, and were expanded somewhat: thus, rinding and burning trees were classed under one head, and seine-, salt-, boat-, and bait-stealing were put into one category, along with seine-breaking. And there were novel rules: thus a ninth rule ${ }^{2}$ prohibited taverns for wine and tobacco, a clear proof that a brisk trade was being carried on with South Europeans and Virginians; and a tenth rule $^{2}$ enjoined Divine Service to be read on Sunday, so that there were now ten commandments. The Order concluded with two executive provisions which prescribed the mode in which these ten commandments were to be enforced. One provision ${ }^{3}$ sanctioned the customary law under which the first, second, and third fishing-captains who arrived in a harbour became admiral, vice-admiral, and rear-admiral thereof, and ordered these potentates to assist judicially in their enforcement; and the other provision vested criminal justice in the mayors of the south-western ports of England. Both of these executive provisions remained dead-letters; the first, because it was absurd, having regard to the nature of the fishing-admirals, and the second because it was unconstitu-

1 Ante, p. 57.

2 I alter the numbering.

${ }^{3}$ State Papers, Colonial Series, vol. viii, No. I, dated Jan. 24, I634. 
tional, despite an opinion to the contrary by Attorney-General Noy. In order, however, that these rules and provisions might not be void for informality, they were confirmed by a Charter which was afterwards known as the Western Charter, and which repeated word for word the language used by the Star Chamber. ${ }^{1}$ The following April (I634) witnessed the appointment of Commissioners of Foreign Plantations, who are the lineal ancestors of the Colonial Office of to-day, and who inaugurated an energetic and systematic colonial policy.

In 1637 the Commissioners decided that the old patents $I n 1637$ for Newfoundland had lapsed through neglect, and re-granted the old to the Duke of Hamilton, Sir D. Kirke, the conqueror of grants are Quebec (1629), and others, all that had been granted to Guy superseded and former patentees. But there were differences in the new to Kirke's patent. The colony was looked on as one colony, instead company, of being divided into an inner and outer half, as in Guy's patent; the northern boundary was hazily described as $53^{\circ} \mathrm{N}$. lat. ${ }^{2}$ or Belle Isle Strait, instead of being described as $52^{\circ} \mathrm{N}$. lat., and the exemption of fishing and incidental rights from the Governor's jurisdiction was pushed to two logical and dangerous conclusions: first, there were to be two separate kinds of control, the Governor controlling the settlers, while the fishing-admirals and mayors under the charter of 1634 controlled the fishermen; and secondly, there were to be two a vix. separate areas of control; an invisible line being drawn six miles from the seaside, which if the settlers crossed they suffered a sea-change, were partially transformed from settlers into fishermen, and might neither build houses nor farm, but could only build forts, fish-stages, and cook-rooms. In so far as these provisions were new, they were ignored. Settlers still lived, built, and farmed as they had always lived, built, and farmed, within a quarter of a mile of the shore $;^{3}$

${ }^{1}$ Feb. 10, 1634.

2 Comp. Purchas, Pilgrims, vol. xix, p. 429.

3 See e. g. Calendar of State Papers, Colonial Series, Add., I574 to 1674, pp. I $57-63$. 
and it is very doubtful whether any settler ever wandered further inland than six miles before the second half of the eighteenth century.

As Gover- Sir D. Kirke, the first Governor under the new régime, nor, Kirke introduces rent, licences, and excise, $1638-53$, made Ferryland his capital, occupied it with his settlers, who were variously estimated at thirty or one hundred persons $\left(163^{8}\right)$, made Lord Baltimore's house (which was within a quoit's throw of the sea) his residence, mounted in 'Ferryland, St. John's, Bay Bulls, etc.', 'some few,' or according to others fifty-six cannon; and, if settlers were so insubordinate as to live by the shore or to sell strong drink, he fined them, or, in other words, levied rent and licence fees. $\mathrm{He}$ also levied, or said that he levied, under a special power in his charter, an excise of five per 120 fish on alien fishermen. He loved the air, which, he said, perfectly well agreed with all God's creatures except Jesuits and schismatics; and was loath to leave what he loved in 1640 , when he was re-called, and replaced for awhile by two merchants named John Downing and William Rigby. In 1649 , by special request from Charles I, his sister Lady Hopkins joined him, his wife and family, at Ferryland $;^{1}$ and in $\mathrm{r}_{5} \mathbf{I}$ he was summoned home by Cromwell's Council of State on suspicion of complicity into which with Prince Rupert. Commissioners were appointed to Commis. sioners inquire into Kirke's profits from licences, rents, and excise, inquire; to collect the same, and to stand possessed of his property, especially his cannon, pending inquiry. New Commissions, for one year only, were issued in $1_{6} 6_{2}$ and $16_{53}$ to the same effect. Sir D. Kirke was allowed to return to Ferryland in 1652 , but died in 1653 , probably in an English prison, where he was detained at the suit of Cecil, the then Lord Baltimore. Before his death he was cleared of complicity with Prince Rupert and his possessions were restored. It was said by Cecil, Lord Baltimore, that before his death he curried favour with Cromwell by making Cromwell's son-in-law, Claypole,

${ }^{1}$ Charles I's letter, Nov. 16, 1648, is in Egerton MSS. 2395, fol. 36. 
and Colonels Rich and Goffe, partners in his patent ${ }^{1}$; but this statement is more than doubtful. Sir D. Kirke's wife, sister, children, and grandchildren were still living in Ferryland in 1673 , and his son in Renewse in 1680.

The Commissioners appointed under the Commonwealth ruhich Com( $6_{5} \mathrm{I}$ et seq.) acted also as Governors. Convoy-captains missioners assisted them, or formed part of the Commission when it acted helped by executively. In $165 \mathrm{x}$ and $16_{5} 2$ the Commissions were for convoy one year only, and the Commissioners were three or more in captains number, the joint acts of any two of them being valid. In betweeen 1653 John Treworgie, a Devonian by origin and a New 1660. Englander by domicile of choice, and then resident in Newfoundland, was appointed sole Commissioner, for one summer only, but was 'assisted' by the convoy-captains; and in $\mathbf{r} 65^{6}$ the Commissions and Instructions were issued 'to the Commander-in-Chief of the convoys going thither and the Governor there ', as though these functionaries were distinct persons and the Governor were resident. Perhaps Treworgie was meant, for Treworgie called himself Governor in 1660. On the other hand, Treworgie's title was more probably a mere survival, and a reminiscence, and he called himself Governor, long after his office expired, even as Collins did some sixty years later.

The Commissions of the Commonwealth depended upon The Comthe navy, which was only present during the short fishing varied the season. In dealing with the eternal fishing question, what I Western have called the ten commandments of 1634 were re-enacted levied the with hardly a variation, but the executive provision which tax on endowed the mayors of the south-west parts of England with aliens' fish an illegal jurisdiction was omitted, and the crude six-mile of the coast

1 Cecil, Lord Baltimore's petition, June, 166o (Colonial Entry Book, which was English. vol. $1 \times v$ ), assumes that Sir D. Kirke was alive in $16_{55}$, and it was addressed to Charles II : so that he is inaccurate as well as interested.

2 Instructions by the Committee of Trade to the 'Commander-inChief of the convoys-going thither and the Governor there', July I, 1656. State Papers, Domestic Interregnum, vol. 77, fol. 213 . 
veto in Kirke's patent was softened into a veto on settlers building or farming ' upon or near' the drying-grounds and ships' rooms of the fishermen. The Commissioners had jurisdiction over all British subjects, and levied an excise on fish caught by aliens 'as far as Trepassey ', ${ }^{1}$ that is to say, on the coast between Trepassey and Cape Bonavista. No tax on aliens was ever levied outside these limits. The tax doubtless drove away those aliens, who had not already withdrawn from the coast which lay within these limits, and gave a finishing touch to the exclusively English character which events had already indelibly impressed upon this portion of the coast. It was true that 'from Bonavise northward to Trepasse southward is all that ever was and is now (1668) possessed by the English'.2 Those limits were not defined by parchment but coincided with those of the six sub-colonies, which Kirke's colony had absorbed, and represented the de facto out-and-out English colony which had at last attained historic reality.

The Com- The idea of annual Commissioners, who were neither settlers missioners were new, nor fishermen-visitors, but were or were assisted by the officers temporary, of the annual convoys of State ships, was new and appropriate, and be-

longed to or and a characteristic example of the constructive statesmandepended ship of the Interregnum. It was shadowed, however, by an on the StateNary. idea which was also new and appropriate, and involved the complete destruction of the colony. The contest between these two ideas must be reserved for the next chapter.

1 John Downing in Br. Mus. Egerton MSS. 2395, fol. 560, and in Calendar of State Papers, Colonial Series, Nov. $24,1676$.

2 Calendar of State Papers, Colonial Series, 1668? p. 560. 


\section{AUTHORITIES.}

Colonial History, during this chapter, becomes almost distinct from general history, and few references to the Domestic Series of State Papers are required. The State Papers should be sought with the Calendar of State Papers, Colonial Series, America and the West Indies, I 574 et seq., in hand, and the latter can often be used as a substitute instead of as an index - as to which see my note at the end of chapter II. Some slight difficulty occurs owing to the alteration of the titles and numbering of the volumes, especially those relating to the Commonwealth, since the Calendars were published.

In the State Papers Newfoundland begins to have a separate 'Entry Book' to itself in 1623 , as though its separate history began then.

Hakluyt, Principal Navigations, 2nd ed. was published in I5991600 and is therefore valueless for this chapter, for which Purchas's Filgrims, originally published $1625-6$, vol. xix, in Maclehose's edition, 1906, pp. 406-48, sets apart a special corner containing Guy's and Wynne's letters, Whitbourne's book, and Guy's patent; as though Newfoundland had at last begun to be a separate entity with a history of its own.

Prince Society, Boston, U.S., Captain John Mason ... including his Tract on Nervfoundland, $16_{20}$, ed. by C. W. Tuttle, 1887 .

Ibid., Sir William Alexander and American Colonization, ed. by E. F. Slafter, 1873 .

Bannatyne Club, Edinburgh, Royal Letters, charters, and tracts, relating to the Colonization of New Scotland, ed. by D. Laing, 1867 .

Orpheus Junior, The Golden Fleece... transported from Cambrioll Colchos out of the southernmost part of ... Nerefoundland, 1626. The author is Sir W. Vaughan. This book is in prose!

Robert Hayman, Quodlibets lately come over from Neru Britaniola Old Nerefoundland, 1628 . This book is poetry!

Of secondary authorities :

H. P. Biggar, Early Trading Companies of New France, 1900. This scholarly work deals with the North American colonies 1497 to 1633 .

Richard Brown, History of Cape Breton Island, 1869.

John Doyle, English in America, Virginia, Maryland, and the Carolines, 1882 ; The Puritan Colonies, 2 vols., 1887.

These writers throw side-lights on the external relations of Newfoundland.

Doyle's works are classics in regard to the early history of British colonization generally.

There are four important histories of the colony of Newfoundland :

Lewis A. Anspach, History of the Island of Nerofoundland, 1819. 
Rev. Charles Pedley, History of Nerufoundland from the earliest times, 1863 .

John Reeves, History of the Government of Nerwfoundland, 1793.

Daniel Prowse, History of Nerefoundland, Ist ed., 1895, 2nd ed., 1896. The second edition omits the chapters on French colonies and fisheries, Labrador, Railways, Telegraphs, and Fisheries, the Bibliography, and many of the Statistics, and adds a chapter on the Churches. The numerous extracts from MS. and other authorities in the form of Appendices at the ends of chapters, being often not verbatim, though never seriously inaccurate, and the Statistics need revision. The industry of Judge Prowse is admirable, the documents are well selected, and the book, despite eccentricities of style, is the standard history of Newfoundland.

The dates of the four histories are important, as the authors write as first-hand authorities with regard to their own times. On the early history the three earlier historians are superseded. 


\section{CHAPTER IV}

\section{THE CRISIS AND THE CONVOYS, 1656-1688}

THE six colonies had melted away or merged into one The quesfishing colony with definite boundaries, with inhabitants ${ }^{\text {tion }}$ to be of one origin under one Governor, whose powers however was raised were sometimes in commission and sometimes non-existent. The Governor was moribund, or in a state of suspended animation, and the infant colony seemed perishing of inanition. The most permanent element in the colony consisted of many transitory fishermen, who had fished for nearly a century and a half, and did not wish a colony to exist. The few fixed colonists, who followed the same pursuits and haunted the same spots as the evanescent visitors, had been there less than fifty years, and were hourly menaced with extinction. A crisis occurred about the time of the Restoration, and was acute for twenty years $\left(165^{6} 6-75\right)$. Either the colony must be abandoned and its Governor must be left to die a natural death, or the State must appoint permanent or regularly recurrent Governors and make the Colony go forward. No half-way course was possible. Innumerable arguments were used one way or the other without effect; and the pressure of French rivalry, the stern realities of war, and the watchfulness of the Royal Navy proved the sole decisive factors.

The issues of Life and Death were placed into the scales (1) in 1656 , on three occasions and on the first occasion by the Council of State of the Commonwealth. At the close of ${ }^{6} 65^{6}$ the Council of State ordered a Committee to report whether it might be fit to offer to his Highness as the Council's advice 'that the prosecuting of the Plantation there should be discontinued '.' It is not known what report the Committee

1 State Papers: Domestic, Interregnum I, vol, lxxvii, fol. $53^{2}$. Nov. 27,1656 . 
made; nor was any action taken before the end of the after which Commonwealth. After the Restoration no Governor was theWestern appointed for the island by the Kirkes, but Cecil Lord
Charter was reenacted with $a$ clause against boatmen Baltimore, having vindicated his title to the province of Avalon, appointed Captains J. Rayner and Pearse joint Governors, and afterwards (I663) Captain R. Swanley sole Governor thereof. Efforts were made to induce the King to passengers; appoint William Hinton, or Captain R. Robinson, R.N., or William son of John Downing, Governor, not only of the whole island but of the fishermen as well, and petitions to this effect evoked counter-petitions for the abolition of all Governors, whether limited or unlimited, special or general. But the Government ignored both the petitioners and the counter-petitioners, and evaded or postponed decisive action by renewing in $166 \mathrm{r}$ the so-called Western Charter of $\mathrm{r}_{34}$, with a superadded eleventh commandment, prohibiting fishermen from carrying any one to Newfoundland other than the ships' crew or settlers. An alarm had been raised that 'the fishery' was carried on 'without fishing-ships' or ocean sailors, but only by boatmen, who went out as passengers and fished in the bays either in boats of their own, or as day labourers in the boats of other small boat owners, and sometimes (worst of all) fled to New England and settled there. What, it was asked, had become of the arguments of Hitchcock and the other prophets of the fishing school? Either these boatmen were not ocean sailors or they were. If they were not, distant fisheries were not educating ocean sailors; if they were, distant fisheries were the means of draining away ocean sailors to New England, and New England could not help if old England were invaded as in I 588 . Indeed, most of the alarmists went further, and wrote of New England as though it were a foreign country. The cry that our best citizens were being 'spirited away' had been raised in ${ }^{16} \mathrm{II}^{1}$ and was now raised with regard to

1 Ante, p. 56. 
different people, and with more reason and success. Such was the origin of the added clause of $r 66 \mathrm{r}$, which was directed against absentee boatmen not against settlers. But this added clause was soon destined to receive additions to itself, which seemed to involve resident as well as absentee boatmen in a common proscription.

In 1670 the question, to colonize or not to colonize (2) in 1670 , Newfoundland, was once more placed upon the balance, and after which the colonial cause would have kicked the beam, had not new anti-pasfetters been forged and thrown into the rising scale. The senger eleventh commandment of $\mathrm{r} 66 \mathrm{I}$ was expanded, and in its directed expanded form forbad fishermen to take out settlers as against 'passengers'; and a twelfth commandment ordered them to take out one apprentice ${ }^{1}$ for every four sailors, and to bring back all whom they took out. Hitchcock's name was writ large in the twelfth commandment, and it is easy to see in the eleventh a corollary from the twelfth commandment, and to trace some seventeen other new rules which were now passedallowing subjects and forbidding aliens to bait between Capes Race and Bonavista, and re-enacting the six-mile veto on all who settled within those limits, ${ }^{2}$ to a desire to codify, or to the usual enthusiasm for distant fishing and for a numerous population in England. The settlers on the spot were sacrificed to the fishermen from afar, and an ominous recommendation that the settlers should settle in some other colony passed the Council of Plantations, although it was afterwards rejected by the Privy Council. Nor was this rejection more than a brief reprieve.

The question, to be or not to be, was asked for the third (3) in 1675 , and last time in 1675 , and on the third time of asking the after which noes prevailed. The colonists were to be assisted in going captains to Jamaica, St. Kitts, or elsewhere, or, if they refused, the went out prohibition to live within six miles of the shore was to be the colony, enforced for the first time. No one lived except within

1 Called 'green men'.

2 Ante, p. 69. 
a quarter of a mile of the shore; therefore the colony was doomed, and convoys were appointed to execute the doom. Then Fate ironically ordained that the very orders which sentenced the colony to death called into activity the only influence which could revive it, and not only did revive it, but conferred on it new prosperity. That influence was the Royal Navy. Two influences brought ships of the Royal Navy to Newfoundland-danger and taxation.

(convoys Convoys had been advocated by 'the Treasurer and were due to danger from pirates, Dutchimen, and Frenchmen, Company with the Scottish undertakers in Newfoundland'which is probably a periphrasis for J. Mason-in 1621 , by Whitbourne $(1620,1626)$, by Vaughan ( 1626$)$, and Lord Baltimore $(1628)$ as a protection against piracy and war; and convoys sailed, or were ordered to sail, in 1623,1629 , I640, I649, I651, I653, I655, I6 66 (?), I657, I660 (?), 1666 (?), I67I, I672, and 1675 , in order to protect the annual fishermen from these dangers. Convoys took two forms-the form of a privateer equipped by the Governor, in the expectation of winning prize-money (1629, 1640, 1666); and the form of King's or State vessels, which were usually two in number. Before $\mathbf{r}_{5} \mathrm{I}$ want of money was the chief obstacle in the way of providing State vessels. Mason, Whitbourne, and Vaughan urged that the expense should be recouped by a small tax on fish, but when this course was proposed in 1637 the fishermen spurned it. Consequently State vessels only sailed as convoys, when questions of cost were put on one side in the face of some pressing danger. Danger came from pirates like Easton, Sir H. Manwaring, and Ralegh's erring captains (1612-2I), from the French (1628-9), from pirates consisting of Moors, and of the scum of Europe, who joined the Moors and were called 'Sallee rovers' (1637), from Prince Rupert (1649-52), the Dutch (1652-4), the French (1654-5), and again the Dutch (1665, 1673). There were two actual attacks on Newfoundland by the Dutch: in $\mathrm{r}_{65}$, when De Ruyter raided St. John's, the 
Bay of Bulls, and Petty Harbour in revenge for English attacks upon Dutchmen in West Africa, and in 1673, when De Boes raided Ferryland immediately after his short-lived re-conquest of New York. Newfoundland was regarded as a pawn in the European war-game, and it was within reach of the least of the combatants. The very places which were attackedSt. John's, the Bay of Bulls, Petty Harbour, and Ferrylandwere the very places which Kirke's foresight had fortified, and a remark by De Ruyter, that six cannon would have prevented him from entering St. John's Harbour, coupled with the unaccountable disappearance of Kirke's cannon, turned men's thoughts to forts and garrisons. But the Dutch danger was transitory and remote, and a new, nearer, and more deadly danger began to loom on the political sky. France, which was now the boldest and strongest competitor for empire, annexed and occupied Placentia.

In 1660 a Royal Commission appointed Sieur Gargot, the Frenchwho was the captain of the fleet which went every year from France to Canada, Governor of the Port of Placentia. ${ }^{1}$ In Placentia $1662 \mathrm{Du}$ Mont, then on his way to Quebec with the soldiers in 1662 ; and colonists for whom Pierre Boucher had asked (I66r), landed at Placentia, proclaimed it French territory, fortified it, and left a garrison of thirty soldiers and a priest behind him as he went on his way. ${ }^{2}$ In the same year an Irish (?) inhabitant of St. Mary Bay, and some Indians from the continent who were poaching beavers near Cape St. Mary, were arrested by an English bailiff; but French allies of the Indians came on the scene, declared that France was now sovereign of the south ports of the island, arrested the bailiff, and took him prisoner to Placentia. ${ }^{3}$ In 1663 Gargot was ordered to take out certain families and stores from $\mathrm{La}$

1 Charlevoix, History of New France, ed. J. Shea, vol. iii, pp. 146-7.

2 Calendar of State Papers, Colonial Series, April 15, 1668 : Colonial Papers, vol. xxii, Nos. $65-7$.

3. Br. Mus. Egerton MSS. 2395, fol. 47x, Jan. 27, 1670. The context implies that the Indians were continental. 
Rochelle and hand them over to Du Perron Thalour, 'commandant in that isle'; ${ }^{1}$ and in 1667 we hear of a resident Governor, doubtless De la Poype, starting from La Rochelle for Placentia with about sixty families ' of several trades', I 50 soldiers, and some guns. ${ }^{2}$ La Rochelle was also the port from which the earliest Acadian settlers had sailed. It seemed as though France was about to occupy the principal approach to the Gulf of St. Lawrence as well as its southern shores with Acadian colonists.

This new danger had been foreseen some sixty years before. It was hinted at in the document of 1600 ; the petitioner of r62 I wrote, 'if we don't send convoys France or even Spain will' ; Hayman wrote that 'the French and Biscayans will dispossess us' ( $\left.163^{\circ}\right)$; and Sir F. Gorges, Lord Baltimore, Captain R. Robinson, and Captain W. Davies reiterated the same fears. For those who had eyes to see, the growth of French power in Canada and Newfoundland menaced the existence of the English fisheries and settlements in Newfoundland. The authors of the orders of 1670 and I675, which opposed English settlement in Newfoundland, were statesmanlike from their point of view except in one respect. They minimized the French danger. 'Reason and experience', said Captain R. Robinson, 'teach us in peace to provide for war.' But the statesmen to whom Captain Robinson spoke closed their eyes tight, and declared that there was no danger from France; or (and here their better instincts spoke) if there was, the convoy's would provide against it.

and to the The second influence which drew state ships to NewfoundNavigation land was fiscal. After the Navigation Acts, $165 \mathrm{I}, \mathrm{I} 660$, and 63.)

1 French Records, Paris; Ministère des affaires étrangères: Fonds Amérique, vol. v, fol. 35 ; Ordre et Instruction au Sieur De la Rochette Gargot... allant faire le voiage de terre neufve et Canada. May 4, 1663; kindly found and copied for me by Dr. Doughty, Archivist of the Dominion of Canada.

2 Calendar of State Papers, Colonial Series, Jan. 8, I668: Colonial Papers, vol. xxii, No. 5 . 
1663 , were passed, two duties were assigned to the convoysself-defence and fiscal supervision, and it was assumed that the latter would pay for the former duty. The Acts of $I_{5} \mathrm{I}$ laid down a rule, which limited the carrying trade between England and her Colonies to British ships, except in cases which do not concern us; but the Dutch, against whom the Act was aimed, hardly ever traded, and never fished, near Newfoundland, so that the rule concerns us almost as little as its exception. By the Acts of 1660 and 1663 no colonial sugar or tobacco might be sent to foreign countries, and no European goods, except wine from the Azores and Madeira, and except salt, might be sent from foreign countries to our colonies ( $166_{3}$ ), but each of these forbidden products must be sent direct from the place, where it was produced, to 'England, Wales, or Berwick' (r663). These measures vitally affected Newfoundland. New Englanders, amongst other necessaries of life, ${ }^{1}$ brought West-Indian sugar, molasses, and rum, and Virginian tobacco, while ships from France, Spain, and Portugal brought brandy to Newfoundland; and if Newfoundlanders bought this sugar, tobacco, or brandy, they sinned against the Navigation Acts. Nor was this all. Newfoundlanders liked sugar only less than they liked salt, wallowed in rum, molasses, and brandy, and smoked tobacco from morning to night, but a man must be very simple who supposed that all these commodities were bought by Newfoundlanders with fish or money. Indeed, there is overwhelming evidence that most of the colonial sugar, molasses, rum, and tobacco went through Newfoundland to the continental Europeans, and that most of the European drinks went through Newfoundland to the American colonists. Direct traffic between a colony and a foreign country was regarded as the deadliest of all deadly sins by the statesman of that time. Moreover, the sinners sinned in the light of

1 J. Downing says, 'Bread, peas, flour, beef, pork, butter, tar, boards, tobacco, black sugar, and molasses.' Egerton MSS. 2395, fol. 56 I.

VoL, V. PT. IV 
day and before the eyes of all men. The New Englanders, aided after 1674 by the New Yorkers, did the carrying trade on the western shores of the Atlantic; the European fishermen and English sackmen were their own carriers across the Atlantic; and on the eastern shores of the Atlantic little remained to be done, and that little was done by Dutchmen. Newfoundland was the exchange and mart, or, in the words of a Bostonian exciseman, 'a magazine of contraband goods'. Doubtless the statesmen of the Commonwealth and Restoration intended to recoup themselves for the cost of providing convoys by suppressing illicit traffic in its principal seat and stronghold, so that the convoys might even prove an economy, and patriotism was quickened by a desire for gain. Those pecuniary intentions proved absolutely futile. Smuggling throve with unexampled prosperity under the aegis of the convoys. On the other hand, the convoys became a regular, and after 1675 an annual institution, and produced farreaching effects neither of a warlike nor of a fiscal but of a purely political character, which nobody anticipated.

Theconvoy-

In 1675 Sir J. Berry, in 1676 Captain Russell, and in captains who were to destroy, described the colony as it was, saved $i t$, 1677 Sir W. Poole, commanded the convoys, and were commissioned to collect statistics and to make reports. Their reports were independent but unanimous. The colony must at all costs be saved from France. The Spanish-Biscayans and Portuguese were 'few and inconsiderable' and kept to northern Newfoundland and to the Great Bank where Englishmen did not fish. But with France there was not only commercial rivalry but a struggle for existence. If we left, the Frenchmen would certainly step in, and keep the colony and its fisheries to themselves. Details were published for the first time which threw a new and vivid searchlight on the life of the community. ${ }^{2}$ There were three classes. In the first place 523 settlers were scattered in 28 settlements, all of which

1 Calendar of State Papers, Colonial Series, Jan. 12, 1687; Nov. 5 , I 700.2 This is the account of 1677 : Br. Mus. MSS. 13972. 
except Trepassey were on the east coast between Cape Race and Cape Bonavista. Of these settlements St. John's $\left(87^{1}\right)$, Bonavista $\left(63^{1}\right)$, and Carbonear in Conception Bay $\left(55^{1}\right)$ were abnormally large, and Harbour Grace $\left(22^{1}\right)$, Ferryland $\left(2 \mathrm{I}^{1}\right)$, Renewse $\left(19^{1}\right)$, Bay Bulls $\left(19^{1}\right)$, Fermeuse $\left(17^{1}\right)$, Petty Harbour $\left(\mathrm{IO}^{1}\right)$, and Trepassey $\left(\mathrm{IO}^{1}\right)$ were of average size. Several names like Cuper's Cove, Aquaforte, and Quidi Vidi figured in contemporary lists, but not in this list, which evidently merged them in their neighbours, thus underrating the extraordinary dispersion of the settlers. These thirty or forty odd seaside settlements, none of which were sufficiently settled, and few of which were sufficiently large to deserve the name of villages, were united by steep pathways through dense woods, so that the English colony was a noun of multitude, and resembled an archipelago between the islands of which intercourse was easy and perpetual. They had no intercourse with Placentia except through the fishermen and traders who annually wandered in from over seas, so that, to all intents and purposes, Bristol, Lisbon, and Leghorn were half-way to Placentia. Of the settlers $3^{6} \mathrm{I}$ were women and children. To uproot these people would be to uproot an entire countryside. Secondly, around this nucleus of permanent families there gathered a fluctuating body of $\mathrm{r}, 34^{2}$ boatmen, servants, and the like, only 23 of whom were female. These hangers-on came each year with the fishermen, who left them behind in order to save freight and food, and those who were left behind minded and mended boats, and returned home next year, or dropped off and drifted away to New England. All hired boatmen were, unlike the fishing crews, wage-earners, who came and stayed and went wherever wages were high. These were they against whom the orders of r66r, r670 and 1675 had idly fulminated. The 'inhabitants', as these two classes were called, dwelt in 167 houses, tended 12 horses, I 31 sheep, 480 cattle, 845 pigs, and I 44

1 = settled population, 1677 . 
gardens, busied themselves with fishing during summer, and with boat-building during winter, and sometimes during a few weeks in autumn stalked deer and caught seals, otters, and beavers near Cape Bonavista. But the fur-trade was almost entirely monopolized by Frenchmen, who plied their industries far away from where Englishmen dwelt, and were aided in it by Indians, with whom the Englishmen did not come into contact. What the nomadic English fishermen said of the inhabitants of Newfoundland was true : they were very few, they were not husbandmen as in other colonies, and they were fishermen through and through. Thirdly, there were the nomadic English fishermen and sackmen, who came and went almost as punctually as the equinoxes, and who outnumbered the permanent settlers by ten to one, and the 'inhabitants' by three to one, and complained that they, the hardy sailors and ideal fishermen of Tudor antiquity, were being elbowed out by lazy prosperous upstarts of the Stuart age who were not true sailors. Their complaint was true in a sense. The 'inhabitants' were boatmen who caught one-third of the total catch, which was more than their fair share, without ships or experience of the open sea. The nomadic visitors were splendid ocean sailors, and owned 22 I ships averaging 74 tons apiece, which was four tons more than Hitchcock's buss, with 688 guns. Modern critics would inevitably infer that the inhabitants produced better results with less expenditure than the nomads. Contemporary observers as inevitably inferred that the nomads added to, and the inhabitants sapped the strength and wealth of England. Contemporary and modern critics would be equally convinced that it was unthinkable that a mere handful of scattered fishermen should either rule or be ruled by a vast mob of nomadic but united fishermen who were their rivals; that the settlers were far too deeply and widely planted to be transplanted ; and that the only solution of the crux was to appoint strong independent autocrats, who were not fishermen, but whom fishermen 
would respect, to rule over the contending factions. The dry figures of the convoy-captains were 'half-battles', and their arguments were irresistible. Orders were sent early in 1677 suspending those of 1675 , and in 1680 the Lords of Trade changed the six-mile veto into a quarter-of-a-mile veto on settlers, ordered the fortification of St. John's and the appointment of a Governor with power to punish inhabitants, but without power over the nomads except to send them to their ships.

This unexpected change of face led to a still more and acted unexpected development. The convoy-captains not only as its prompted but became the only new solution. During their when prebrief visits, briefer than those of the nomadic fishermen, but sent, the longer than those of a judge on circuit, they exercised or otherwise usurped the functions of Governors until Governors were anarchical. appointed. The appointment of Governors, though ordered by the Council, took no effect because it was not decided by whom or how they should be paid, and when the question was mooted the Council would not face the facts. It would have been easy enough to collect a tax. Each principal harbour had a principal resident. Fermeuse had George Kirke, and Quidi Vidi had young John Downing, both of whom were sons of Governors; St. John's had T. Oxford, and Harbour Grace had John Pynne, both of whom claimed the prestige of being the oldest inhabitants, and these four residents could easily collect on fish the $\AA_{400}$ a year which was necessary. But from whom? If settlers alone paid the fish-tax boat-fishermen would be mulcted for the benefit of competing ship-fishermen. If settlers assessed and collected the tax from non-settlers the minority would tax the majority. So the Council suggested that both classes should be taxed but only with their consent; and the nomadic fishermen were asked what they would contribute, although their contempt for land-governors was notorious. It is perhaps fortunate that what the fishermen replied is not recorded. The pro- 
hibition of settlements within a quarter of a mile of the shore was a prohibition of what was universal, and was therefore ignored. Nine years passed by without any further result being obtained. Then the long-expected blow fell and war broke out between England and France. But for one interval of repose introduced by the Peace of Ryswick (1697I 702) - like blue sky in the middle of a cyclone-the war lasted twenty-five years (1688-1713). Immediate orders were issued for the erection of forts at St. John's at a cost of

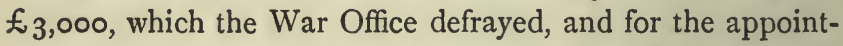
ment of a Governor. The forts were erected and the Governor was once more deferred. Captain R. Robinson wrote that this was the only plantation of its size without Church or State. ${ }^{1}$ He might have added that the Royal Navy was its only Church and State. The strange paradox was accomplished that the messengers and instruments of destruction created the reign of Law; and the executioners proved saviours of society. The presence of the convoy-captains, though intermittent, produced an abiding sense of order among men living without any of its outward and visible signs. During their absence primaeval instincts and habits resumed their sway.

1 Calendar of State Papers, Colonial Series, 1669-74, No. 369.

\section{AUthorities}

See note to chapters $\mathrm{V}$ and VII. 


\section{CHAPTER V}

\section{THE FIRST ANGLO-FRENCH DUEL AND ENGLISH VICTORY, 1688-1713}

SEventy miles away to the south-west of St. John's lay TheFrench Placentia, the capital of the French colony; but no dwelling colony conor pathway lay between the two capitals. St. John's faced Placentia eastward towree eastward towards Europe, Placentia Bay southwards towards sub-settlethe highway between Europe and Canada. About half-way ments, up the east coast of Placentia Bay there is an inlet which, some two miles from its mouth, contracts into so narrow a neck that only one ship can pass upward at a time, and which then expands into a harbour. On the south side of the neck was the finest drying beach in Newfoundland, which settlers were not allowed to desecrate with gardens ${ }^{1}$; and on this beach, but inside the neck, was Grand Placentia. Point Verte lay outside the neck, on the lip so to speak, and Little Placentia some four miles north round the corner. The east coast of Placentia Bay is harbourless except at Great and Little Placentia and Point Verte; therefore these three settlements clung together like one settlement, and all the settlers retired in time of danger within the neck, which was guarded by a fort and great guns. Placentia was a trinity of three villages, the greatest of which was Grand Placentia. On the north-west side of the Bay of Placentia lay Paradise Sound and the adjoining islands of Mérichon, Audierne, Egeron, and the like ; and tiny settlements by this sound and on these islands formed the first and nearest sub-settlement of the colony of Placentia. French Biscayan fishermen visited but never settled in Little Burin, Great Burin, Martir (Mortier), St. Lawrence, and Chapeau Rouge, on the western extremity of Placentia ${ }^{2}$ Bay; so that a wide gap separated the first from the second

1 Canada, Documents relatifs, Ecc, vol. i, p. 384 .

2 La Hontan, Nouveaux Vojages, I703, ed. I905, p. 338. 
sub-settlement. If we now pass westward out of Placentia Bay, Fortune Head, Grand Bank, and the islands of St. Pierre and Miquelon near the foot of the peninsula which separates Placentia Bay from Fortune Bay, may be classed together as a second sub-settlement, while in Hermitage, Connaigre (Cap Nègre), and Britton (Bertrand) Bays, on the north-west of Fortune Bay, there was a third tiny sub-settlement of Placentia. The French settlers (excluding servants) and servants were as follows: ${ }^{1}$

\begin{tabular}{|c|c|c|c|c|c|c|}
\hline Settlers at & $167 \mathrm{I}$ & 1687 & 1691 & I693 & I704 & I 710 \\
\hline $\begin{array}{l}\text { Placentia } \\
\text { Second sub-settlement } \\
\text { Elsewhere }\end{array}$ & & $\begin{array}{r}123 \\
25 \\
18\end{array}$ & $\begin{array}{r}108 \\
42 \\
5\end{array}$ & $\begin{array}{r}126 \\
33 \\
5\end{array}$ & $\begin{array}{r}158 \\
? \\
?\end{array}$ & $\begin{array}{l}213 \\
? * \\
12\end{array}$ \\
\hline Add servants & 73 & $\begin{array}{l}x 66 \\
474\end{array}$ & $\begin{array}{c}\text { I55 } \\
?\end{array}$ & $\begin{array}{l}164 \\
191\end{array}$ & $\begin{array}{l}165 \\
390\end{array}$ & $\begin{array}{l}225 \\
354\end{array}$ \\
\hline Grand Total & & 640 & & 355 & 555 & 579 \\
\hline
\end{tabular}

* Was 47 in I $7 \mathrm{Ir}$.

Placentia being supreme,
In 1687 the women of the colony were 63 , of whom 46 were at Placentia, and the cattle of the colonists were 53, of which 47 were at Placentia. The King's fleet, which sailed between France and Canada, and the French fishing fleets, which frequented the south coasts, annually visited it; but the St. Malo fleet, which frequented the north-east coasts between Cape Freels and Belle Isle Strait, had little if anything to do with it, or with any other French settlement, nor did the fishermen of St. Malo settle. Placentia, including its daughter settlements, resembled an isolated wayside inn on the highway from Paris to Quebec; and the highway ran between Cape Breton Island and Newfoundland.

No figures could illustrate more vividly, than those which

${ }^{1}$ Abbreviated from copies of the French Records at Ottawa. 
have been cited, the loneliness and ascendancy of Placentia. St. John's was only first amongst thirty or forty peers, and a network of pathways connected it with its peers. Placentia was peerless and isolated from its sub-settlements, which consisted mainly of islands, and which were abandoned more or less as war went on. At the outbreak of war St. John's was anarchical, or subject to summer rulers who where changed every year, and was without church or chapel, but was the centre of a rich and varied life, like a city that had grown, while Placentia was rigidly Roman Catholic, had three churches, and was divided by clean-cut lines between two classes, the governed and the governors, and, as in most made cities, the latter preceded the former. Placentia was guarded by a fort or two, whose guns were once $18(1662)^{1}$, then $3(\mathrm{I} 68 \mathrm{r})^{2}$, and then $5^{2}$ in number ${ }^{3}$, and whose garrison varied from

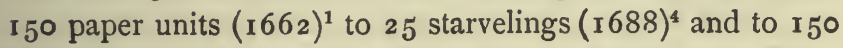
able-bodied soldiers $\left(\mathbf{1} 696^{4}, \mathbf{I} 698^{3}\right)$. When at its best Placentia-including Grand and Little Placentia and Point Verte-was a little larger that St. John's, and only a little less than the entire French colony.

The Governors of the French colony were very visible and being very omnipresent, and the history of French Newfoundland was contained in the biography of six or seven persons and governed, three or four functionaries. First there was the Governor of Newfoundland and Placentia, who ruled the hosts of fishermen, who came and went like birds of passage, as well as the fishing soldiers and settlers, and who was represented by De Brouillan (1691-1 702), or during his illness by De Monic ( $1698-1702)$, then by De Subercase ( $1702-6)$, and then by De Costebelle (r $\left.706-\mathrm{r}_{4}\right)$, who had been 'King's Lieutenant' at Placentia (1695-1706) and was succeeded as King's Lieutenant by St. Ovide, a nephew of De Brouillan (1706-14).

1 Calendar of State Papers, Colonial Series, Apr. 15, 1668.

2 Ibid., Sept. I, I68ı. ${ }^{3}$ Ibid., Nov. 13, 1698.

4 Ordres du Roi, Ser. B., vols. xiv to xix, in the copies of the French Records at Ottawa. Ordres, Feb. 21 , 1688; Apr. 4, 1696. 
L'Hermitte, the third wheel of the chariot of State, was 'Major at Placentia' (1695-I7I4). As though these three functionaries were insufficient, there were many priests, there was one superior ruler, the Governor of Canada, and a famous adven- French Canadian named D'Tberville received from time to turers from time roving commissions from the King to destroy the
the Continent

like D'Iberville intruding now and. then.

English settlements in Newfoundland. His commissions, like those of privateers, were to be executed at his own expense, and the booty was to be shared between him, his associhtes, and the King. Privateers usually confined themselves to white men and the sea, but D'Iberville preferred forays by land, and with red-skinned troops who knew nothing of the sea. He was a born coureur des bois, had sped by land with his American Indians from Quebec to Hudson's Bay, and from Quebec to Schenectady, and midsummer and midwinter midday and mid-night were alike to him. His first plan to destroy the English colony in Newfoundland was laid in 1693 , but before it could be carried out this missionary of destruction was spirited away on a like errand, first to Hudson's Bay, then to Schenectady and Pemaquid, and he only arrived in Newfoundland in 1696 .

Before Before his arrival no incidents of importance had occurred. D' Tberville At Trepassey, which was the only settlement where Frenchmen
arived Williams and Englishmen lived side by side, ${ }^{1}$ the former drove the and Wheler latter out and burnt their houses in 1690 . In 1692 ComPlacentia, modore Williams, and in 1693 Admiral Sir Francis Wheler, on 1692-3,
and Hol- returning homeward from the West Indies, appeared before man defended
Ferryland, 1694. In r689 Captain Herman Williamson, a privateer, sailed against Grand Placentia, seized it by means of a landing party, imprisoned its Governor and inhabitants, plundered it and then left ; in 1690 French privateers paid return visits to Bay

1 Canada, Documents relatifs, \&'c., vol. i, p. 384; Calendar of State Papers, July 3, 1697 .

${ }^{2}$ La Hontan, Nouveaux Voyages dans l'Amérique, Eoc., Letter 23. 
Bulls and Ferryland ${ }^{1}$; and in 1694 Captain W. Holman, an English privateer, was in Ferryland, heard that some French ships were at hand, threatened to burn the settlers' houses, from which they fled at the first rumour of danger, and by these means prevailed on them to stop. He then adopted methods of 'encouragement', which were as eccentric and successful as his menaces, and gave 'to encourage them in time of fight' a hogshead of sherry, twenty gallons of brandy, and a barrel of strong beer. Perhaps it was owing to this encouragement that the defenders saw, or thought they saw. two French ships enter the harbour, fired a few shots, and won a bloodless victory. Captain Holman was rewarded for his valour by the gift of a chain and medal by the Admiralty, and the Council recommended that he should be paid in full for the liquid, and probably contraband encouragement, which he had dispensed with such lavish generosity. Suddenly laughter turned to tears.

On March 31, I696, the King of France adopted D'Iber- De Brouilville's plan of attack, and resolved to attack the English settlements in Newfoundland by land and sea. The ex-Ferryland, pedition by land was entrusted to D'Iberville aided by 'sixty Ec., withIndians from Acadia, together with M. de Montigny, eighty' ville, 1696, (half-breed ?) 'Canadians and some officers, ...D'Iberville will defray all expenses,' and De Brouillan was to 'give the latter one hundred of his soldiers'. Operations by sea were under the absolute control of De Brouillan, and plunder was divisible equally between the King, D'Iberville, and the shipowners of St. Malo, who had undertaken to supply privateers. ${ }^{2}$ The fishing interests of St. Malo had hitherto been mainly devoted to Petit Nord, but there was trade between St. Malo and Placentia; and both the fishing and the trade ships were compelled to return home in autumn, so that De Brouillan so

1 Calendar of State Papers, Colonial Series, Addenda 1691-8, Captain Hawkins's dispatch, Dec. 4, I691.

${ }_{2}^{2}$ Edouard Richard's Supplement (I9OI) to D. Brymner's Report on the Canadian Archives (1899). 
far as his plans depended upon them could not brook delay. Early in September, 1696 , De Brouillan, tired of waiting for D'Iberville, sailed with one King's ship, eight St. Malo privateers, and some soldiers under L'Hermitte and St. Ovide, failed to enter St. John's Harbour, achieved small successes at Bay Bulls and Ferryland-in spite of the resistance of Captain Cleasby, R.N., who was compelled to burn his ship,-plundered the settlers, burnt their houses, and shipped off I 50 Ferrylanders to Barnstaple. The exiles arrived, sick, destitute, homeless, and heartbroken, at the very moment when compensation to Captain Holman, as the saviour of Ferryland, was being approved of by the Committee of Trade. And De Brouillan's deed was only a prelude to the real tragedy.

and D'lber. On November I, I796, the concerted plan was executed. ville and De Brouillan took St. John's, Ec., $1696-$ 7. De Brouillan, L'Hermitte, St. Ovide, and about roo of the I 50 soldiers who garrisoned Placentia, sailed to Renewse, while D'Iberville, De Montigny, and some I 24 (half-breed?) Canadians and Canadian or Acadian Indians, for whom D'Iberville was pecuniarily responsible, stole forth from Placentia-like a pack of wolves-slid over frozen sea-arms, plunged through mossy, half-frozen morasses, splashed 'waist deep' through unfrozen fords, and reached Ferryland, where 'they found twelve horses, very à propos, which they used as provisions', and where after a few days De Brouillan rejoined them. The soldiers and Canadians then marched on St. John's. The first skirmish occurred near Petty Harbour, whence 34 Englishmen sallied forth, and, according to an English account, were driven back by a snowstorm, but according to French accounts were attacked and driven into the town, where $3^{6}$ men were killed on the spot, several were taken, and the rest escaped to St. John's. A second skirmish occurred near St. John's, where De Montigny and 30 Canadians surprised, or were surprised by, 84 or 88 Englishmen hiding behind burnt trees. Shots were exchanged at close quarters. The main French army soon arrived upon the scene. Abbé 
Beaudoin pronounced a general absolution, and the Englishmen, who were badly armed, fled, losing 55 men. A vessel which was in harbour escaped with 100 inhabitants, and, what pained the raiders to the quick, with ' the most precious articles from the private houses'. On November 30 the fort, after three days' siege, surrendered. It had only been held, says Charlevoix, by 'wretched fishermen who could scarcely fire a gun, and their commandant was a simple settler (habitant) chosen by the ships' captains'. The surrenderers feared that the Canadian or Acadian Indians would scalp them, and one eyewitness declared that an inhabitant was actually scalped and forced to walk discrowned into the fort, thus warning the garrison of what was in store for them if they resisted. If this grisly story were true it would recall the picture of Dante's Bertram de Born carrying in his hand his head as a lantern. The horrors of Salmonfalls and Schenectady were not repeated, and in accordance with the terms of capitulation 220 men, women, and children were sent off in a ship, which arrived in Dartmouth on January 9. Another batch of 80 prisoners was dispatched in a ship which was wrecked off Spain. Except a few houses which were left for the sick, all the houses in St. John's were burned. In January De Brouillan, L'Hermitte, and St. Ovide sailed with their soldiers for Placentia, and D'Iberville, De Montigny, and their Canadians made snowshoes like tea-trays, on which they glided noiselessly round Conception and Trinity Bays, laying waste every settlement except Carbonear Island and Bonavista with fire and sword, and taking to Placentia Bay-across the two-mile neck which divides it from Bull's arm in Trinity Bay-and so to Placentia, much loot and 700 prisoners, most of whom escaped and returned. ${ }^{1}$ English and French accounts agree that but for

1 Sieur de Baudoin, Journal, 1696-7; Bacqueville de la Potherie, Hist. de I Amerique Septentrionale, I 722 , vol. i, Letter ii ; Charlevoix, History, ed. by J. Shea, vol.v, pp. 33 et seq.; Calendar of State Papers, Colonial Series, Jan. 14, 1697, \&c. 
300 refugees on Carbonear Island, and some others at Bonavista, the English colony was wiped out. A glance at p. $8 \mathrm{I}$ will show that if Carbonear and Bonavista escaped two out of the three principal settlements escaped, and that the 220 persons who were shipped from St. John's must have consisted to a large extent of the fluctuating hangers-on, whose restoration Orders in Council had been vainly commanding the fishermen to effect during the last thirty years. The French authorities were unconsciously obeying, and they were the only people who ever obeyed, the command to repatriate 'passengers'. Next year the settlers and their families numbered 570 , of whom 176 were women and 268 children. Fathers, mothers, and infants were actually more in number than they were in 1677 . Had D'Iberville and De Brouillan smitten windmills and wineskins their conquests would not have been less complete. But booty as well as conquest was their object. Doubtless they took care not to be out of pocket by what they did; doubtless, too, live stock was wasted, homes were laid low in ashes, and all the Furiesexcept Death-were let loose; but the boats of 1698 exceeded in number those of 1677 , and cautious people, who read of the money losses which were sustained, think of the big bill of Captain Holman and shake their heads.

Naval operations followed, and $a$ garrison was left in St. John's, 1697 .

On July 8, r697, De Sérigny's fleet of five sail left Placentia for the far north with D'Iberville on board; and a month or two later, D'Iberville was playing the part of demon or hero around the shores of Hudson Bay. New naval preparations were made by both sides in Europe. De Nesmond sailed from France with eleven men-of-war and four fireships for Placentia, where he arrived, July 24; and De Pointis, who was operating in the West Indies with a fleet of twenty-six sail, was expected to join De Nesmond at Placentia before the season closed. ${ }^{1}$ Sir John Norris sailed from England

1 Edouard Richard, Supplement, 1901, to Report, 1899, on Canadian Archives, by Brymner, March 13, 1697; Canada, Documents relatifs, Ec., April 2I, 1697. 
with some twelve or fourteen ships-ten of which were described as men-of-war-seized fat prizes at sea, entered the harbour of St. John's, heard, in the middle of July, of five ships of De Pointis's or more probably of De Nesmond's, or of De Sérigny's fleet, cruising in the neighbourhood, and hid in his harbour of refuge, useless though safe. ${ }^{1}$ On August I 8, 'fifteen sail of French ... ten of them great ships'-obviously De Nesmond's fleet on its way back-appeared before St. John's; but Norris lay low in his lug, fearing perhaps a combination between the fleet of De Nesmond with the fleets of De Pointis and De Sérigny - which were by that time 2,000 miles away from De Nesmond's fleet, and more than 2,000 miles away from one another-or perhaps over-conscious of the rich spoil with which his very war-ships were heavyladen. ${ }^{2}$ Sir John Norris was not entirely passive; for he was accompanied by Colonel Gibson and 760 soldiers, who fortified St. John's, and Colonel Gibson urged the fortification of two other ports, on which the inhabitants might concentrate in time of trouble. On the departure of the fleet $33^{6}$ soldiers, including thirty-seven invalids, were left behind as a garrison for St. John's under Major Handasyd, who reported, apparently for the first time, on December 1 2, 1698 , that of the garrison 214 infantry men and some artillerymen had died owing to the severity of the winter $(1697-8)$. The belated date of this casual memorandum, and the significant fact that he is the only commandant of St. John's who never complained of desertion, suggest that ' death' was with him a euphemism for something worse from a soldier's point of view. If the death-rate was high, the wage-rate was still higher in Newfoundland, and it is much more likely that his ranks were

1 Colonel Gibson, in Calendar of State Papers, Colonial Series, November 29, 1697; G. Shuttleworth, in ibid., March 24, 1698; Captain Charles Desborow, Petition, and the annexed Certificate of Peire in Br. Mus. 816. m. 7 (79) (80); Thomas Lediard, Naval History, I $735, \mathrm{p} .720 \mathrm{n}$.

2 Naval Records Society, Life of Stephen Martin, edited by Sir Clements Markham, I 895, pp. 27-36. 
thinned by the gold of summer than by the silver snows of winter. Thenceforth the garrison was maintained at a strength of between sixty and ninety men. An Act of In 1699 the first Act of Parliament for the government
Parliament regulates Nervfoundland fisheries, I699, of Newfoundland was passed. It was a re-enactment of the ten commandments of 1634 in their later versions. The eleventh commandment of $\mathbf{I} 66 \mathrm{I}$ and its accretions were expunged. The twelfth commandment of 1670 was retained. The quarter-of-a-mile veto of $\mathrm{I} 680$ was abolished, and settlers, who seized seaside coigns of vantage, which nomadic fishermen had not occupied since 1685 , might retain them for ever; otherwise they must await the arrival of the fishing-fleets before taking post, and, as before, the first who came were first served, and retained their posts for the season. Disputes. between settlers and nomads were reviewable on appeal from the fishing admirals by the convoy captains, and felonies and aliens' were triable by a judge and jury in England. Aliens' baiting exclusion, and fishing was now prohibited, not merely between Capes Race and Bonavista as in 1670 , but 'in Newfoundland'; and the legislative prohibition, so far as it confined itself to the limits prescribed in 1670 , only confirmed existing facts, but so far as it exceeded those limits was stage thunder, except perhaps in Bonavista Bay. The invasion of Bonavista Bay by English settlers began immediately after D'Iberville's raid and was first announced in 1698. Five years later the English settlers in the northern parts of Newfoundland were defined as those who dwelt in 'Trinity and Conception Bays, and as far northward as the north of Bonavista Bay'.. Northward expansion was stimulated by the war. In spite of the generality of the words of the Act, and of actual expansion on the north of Cape Bonavista, orders, which were issued from time to time to exclude aliens, usually referred to the old-fashioned conventional spheres of French and English activity. Thus in 1698 the Privy

1 Petition, Jan. I I, I 703. 
Council forbad Spanish and Portuguese ships to fish or trade 'between Cape Race and Cape Bonavista within which limits the English have their usual settlements and fishery', and the French Government, while issuing similar prohibitions against Spanish and other foreign ships, allowed English ships in times of peace to fish and trade between Cape Race and Cape Bonavista, and ordered them to be warned off if they fished or traded elsewhere. ${ }^{2} \mathrm{La}$ Hontan wrote that Spaniards fished at Old Port-au-Choix ('Portochua') in his day, and not long afterwards a Spanish ship was confiscated in Placentia Bay by the French, but speaking broadly Spanish and Portuguese fishermen had almost vanished from the shores of Newfoundland before the war began; and now their last remnants finally followed the Dutchmen into the limbo of forgotten things.

The Act did not refer to Governors. The remorseless convoylogic of events was interpreted in the same way by the care- captains ful constitutionalists of the Revolution as it had been by the and mandants Star Chamber, by Cromwell, and by the interested dilettanti acting as of the Restoration. They would not, nor could they, subject Governors. the nomads to the settlers, the many to the few, nor the amphibious to the land-animal; and all of them joined, not in dispraise of the latter, but in praise of the former. Norris's Commission had appointed him 'Governor and Commanderin-Chief of the forts and forces' in Newfoundland; and his successors bore the same title. ${ }^{3}$ During his presence the convoy-captain was supreme in naval and military affairs by virtue of his Commission. During his absence, the commandant of the garrison acted as his understudy, and military power was defined by the Privy Council in such a way, as to confer ' no power over the planters or fishermen, except to

1 e. g. Calendar of State Papers, Colonial Series, March 3I, 1698.

2 e. g. Canada, Documents relatifs, E̋c., Jan. 30, I697; May 28, 1698.

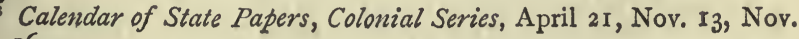
$23,1699$. 
summon them together for common defence in case of actual invasion'.' Moody, when commandant of St. John's, interpreted these double negatives by appointing civilian commandants at Carbonear and Bonavista, which, or islands near which, were duly fortified. There were now three fortified centres-or war-camps - to which the inhabitants could retire in their hour of need, as Colonel Gibson had advised.

A chaplain With Colonel Gibson came as chaplain the Rev. John accompanied the command. ant, and Church History began, I697. Jackson, the first resident English minister of religion since 1629. But the relations between Church and State were not happy. The chaplain, who was salaried by the Society for the Propagation of the Gospel in Foreign Parts, denounced the commandants, and more especially the lieutenants of the commandants. One lieutenant, he said, had a 'hellish mind', and he urged the appointment of his own blameless son as lieutenant in the place of the wicked one. Another lieutenant's house was disreputable, and he urged that the scandalous officer should be evicted, and that his irreproachable self, wife, and eleven children should be installed in the empty, swept, and garnished premises. His accusations might or might not be true, but the home authorities uncharitably imputed them to interested motives, and pressed for his dismissal, which he anticipated by resigning. The army was the origin of the Church in Newfoundland; and we read in 1699 of disbanded soldiers turning settlers here, as they did in other parts of the British Empire. ${ }^{2}$

De Subercase raided St. John's by land from Placentia, I 705 .

After D'Iberville's raid, and the garrisoning of St. John with soldiers, commandants, and chaplains, an interlude of impotence ensued. Admiral Sir John Leake destroyed French fishing-ships and rooms between Trepassey and St. Pierre (I 702). Admiral Graydon, while on his way to England from the West Indies, threatened Placentia (I 703 ),

1 Calendar of State Papers, Colonial Series, March 30, 1698. Comp. Documents relatifs, E'c., vol. i, p. 613; Br. Mus. MSS. I5492, fol. 2, 5 .

${ }^{2}$ Calendar of State Papers, Colonial Series, May 24, 1699. 
but mist, sickness, the late season, and his own irresolution led him to postpone the execution of his threats; and then once more the French invaded the English colony like thieves in the night. In 1704 , or thereabouts, twenty-five families of Micmac Indians were transplanted from Acadia to Placentia. ${ }^{1}$ Early on a Sunday morning in January, I 705, amid deep snow, De Subercase, De Costebelle, L'Hermitte, and De Montigny, with $45^{\circ}$ French soldiers, French inhabitants, Canadians, and Indians, surprised St. John's. In the harbour no guard was kept that winter, and soldiers slept there instead of in the fort (!). Indiscipline met its merited reward, and $3^{1} 7$ inhabitants were folded like sheep into their new church. While the human wolves were performing the functions of sheep-dogs, Lieutenants Moody and Latham put the fort and castle into a state of defence, disposed of their garrison of seventy or eighty men, and awaited the onset of the enemy. De Subercase disgraced himself by threatening them in English, French, and Latin with the fury of the Indians; but the little band of regulars held out heroically, and after thirty-three days' siege the Frenchmen-having loaded up some eighty poor colonists like beasts of burden with their booty-retired, plundering and burning, as in 1697. As in 1697 , De Montigny and his Indians prowled round Conception and Trinity Bay like beasts of prey, and after being baffled at Carbonear Island were rewarded by a stroke of good luck. De Montigny had just written that he was $£_{500}$ out of pocket on his Indians, when a Quaker, named George Skeffington, who had been appointed commandant at Bonavista, 'the spirit not moving him,' surrendered his post ${ }^{2}$ with $\mathrm{I} 20$ men and 8 guns, and ransomed his precious self for $£_{450.3}$ De Montigny, having squared

1 Edouard Richard, op. cit., pp. 393, 394, 433.

2 On Green Island.

3 Captain Moody's dispatch, Nov. 21, I705; 4,000 livres in Canadian Documents, vol. i, p. 6rз. 
his accounts, retired to Placentia by D'Iberville's short cut with his plunder. Then other Canadians, after the manner of blackmailers, returned by the same route to Bonavista, 're-squeezed the Quaker, and re-fleeced the shorn.' Once more it was reported in England and in France that the English colony was all but wiped out, and once more the report was wildly wrong. De Subercase was less deadly than D'Iberville, but there was one difference between this and the earlier foray. Some two hundred inhabitants of Placentia took part in the second foray, and it struck thoughtful people how easily the young Englishmen, who clung to the skirts of the settlers, by whom during winter they were only half employed, might, if drilled and taught or made to fight, sweep the few concentrated Placentians into the sea.

The Commandants organized defence.

Major Lloyd, when commandant at St. John's, persuaded sixty settlers to subscribe $£_{3} \circ$ to send spies to Placentia ( 1703$)$, reconnoitred it himself, found that it was guarded by $35^{2}$ inhabitants and soldiers, and tried to organize a counterattack by land with his eighty soldiers and the thousand odd male inhabitants of the English colony (I 706); but of the latter only forty-two responded and the design was abandoned. Plans for defence made some progress. In 1706 the convoy-captain formally instituted a colonial militia, appointing officers in St. John's and Ferryland, and commissioning Major Lloyd to appoint officers and places of refuge in Conception and Trinity Bays. Seven commanding officers and seven places of refuge were named-a fact which history would not have recorded had not the colonists accused the commandant of serving out half powder and bullets at whole cost. The commandant and colonists were at variance with one another. So were the soldiers and the commandant. In I 704 Major Lloyd reported to Captain Bridge, R.N., that his garrison threatened wholesale desertion. They were demoralized by barrack routine during the winter 
and by being lent out to fishermen during the "summer, "not without profit to the lender. The loan of soldiers to settlers was permitted in English as well as in French Newfoundland, although officers of course had no right to exact commission for the loan. Lloyd's predecessor had written, 'Without some speedy care be taken for better wage for the men it will be impossible to keep them from deserting, for I and my officers are continually up night and day to prevent them '; ${ }^{2}$ and Lloyd's reports were equally alarmist. Captain Bridge took Major Lloyd home to report this news; and in the next year the old garrison was recalled, and a new garrison was sent out in its place. But the new company was even less vigilant and tractable than the old company, and Major Lloyd, its commandant, deteriorated.

The Royal Navy rarely did any definite warlike act near The Royal Newfoundland, and, if it did, did it on the small scale of Navy did a border raid, or as an afterthought-its chief concern being directly. in the West Indies, Canada, and elsewhere. In July and August, 1707, Captain Underdown, R.N., took Major Lloyd on a nautical foray against the north-east coasts of the Petit Nord Peninsula, and destroyed or damaged several armed fishing-vessels, which hailed from St. Malo. Sailing from Cape Bonavista he found no traces of Frenchmen until he was a long way past Cape St. John; but in Fleur-de-Lys Harbour, White Bay, Canada or as it was called Cannerie Bay, Conche ('Lacouch '), Cap Rouge, Croc ('Petit Maître'), and St. Julien harbours, he harried and carried Breton fishermen, burned their boats and stages, and confiscated their gear. The raiders returned without reaching Hare Bay, and their small successes on the north-east coast are comparable to those attained by Sir John Leake five years previously on the south coast of Newfoundland. ${ }^{3}$ In 17 I I, Sir

1 Calendar of State Papers, Colonial Series, March 30, 1698; La Hontan, Voyages, ed. by Thwaites, p. 290.

2 Captain Powell's dispatch; Oct. 5, I 701.

$\$$ Dispatch of Captain Underdown, Aug. 30, 1707. 
Hoveiden Walker, while on his way back from his disastrous expedition against Quebec, entertained a proposal to attack Placentia, referred it to a council of war, and the proposal was rejected, so that he too passed by Placentia on the other side. Both colonists and soldiers complained of the inaction of the Royal Navy. Probably Commodore Williams, Admiral Wheler, Admiral Norris, Admiral Graydon, and Admiral Walker, had they had more knowledge or nerve, might, like Captain Williamson, have seized or destroyed Placentia with landing parties. Possibly, too, they thought that the operation would be useless. But all wars, even the most successful wars, are strewn with lost opportunities, and history has no right to discuss what might have been.

St. Ovide led a third and last raid against

St. John's, s.c., I 709 .

Actual history repeated itself a third time, and on this occasion St. Ovide was the paymaster, who had to repay himself by his plunder. On January I, r 709, two hours before the dawn, in the bright moonlight, there came silently skimming over the white snow, like ghosts, some I 70 Frenchmen, Canadians, and Indians. A sentry saw them and fired. Only eight or ten English soldiers sprang to their posts. A covered way led from the soldiers' fort into the colonists' fort. St. Ovide entered it, for its gate was open (!), rushed the soldiers' fort, seized an unlocked (!) drawbridge which connected the soldiers' and the colonists' fort, and the colonists being, as they said, leaderless, yielded. Major Lloyd, the commandant, was wounded and taken prisoner. A third fort, containing $80 \mathrm{men}$, who forgot $\mathrm{I} 70_{5}$, surrendered. The prisoners numbered 477 , and 200 Placentians were sent for in post-haste to guard them. Then the colonists offered a ransom, payable in fish, and computed at $£_{7,280}$ in value, and the offer was accepted. Verily the last of the freebooters had his reward, but his victories, like those of his predecessors, were mainly pecuniary. The garrison of 80 men was dispersed and its officers were sent to France; $I_{50}$ men were taken to Placentia, where they were forced or persuaded to work for 
their captors for awhile. A few barbarities were committed by the Micmac Indians, who were accordingly sent back to Acadia. But the settlers were undismayed. Women and children were 462 in 1698,636 in 1706,448 in 1707,451 in I 709 , and 612 in 17 ro. They dwindled-but for three years only-to the figure at which they stood in 1698 . Otherwise the permanent population whose homes were in Newfoundland was unaffected. As a conqueror of men and nations St. Ovide must be classed with those who wage war with phantoms.

The war had an important constitutional effect, for The conNewfoundland Governors, like constitutions, were not made captains but grew. From 1675 to 1698 the convoy-captains played acted as the part of Governors. Their reign was briefer than that of commisisa Roman consul. Nominally they were statisticians and Inquiry, inquired into and reported on disorders. But a census had Judges, and been the despot's weapon since the days of Moses, captains people, of the Royal Navy never drew nice distinctions between interrogatives and imperatives, and the words 'oyer' and 'audiencia' remind us that ears are the distinctive attributes of judges. Instructions were annually given to the convoycaptains to inquire into breaches of the latest editions of, and additions to the old decalogue of 1634 , and even before the Act of 1699 , which invested them with judicial attributes, we read from time to time of offenders being whipped or ducked at the yardarm, and of offenders' houses being removed. In addition to compulsory, there was a voluntary jurisdiction, and masters and servants referred to them their mutual disputes. 'It hath been customary', wrote George Larkin (I 701 ), 'for the Commander-in-Chief upon complaints to send his lieutenant ${ }^{1}$ to the several harbours and coves to decide all differences and disputes that happen betwixt commanders of merchant ships and the inhabitants and planters, and betwixt them and their servants,' and he added 1 i. e. 'surrogate' in Admiralty Law. 
that 'he that makes a present of the most Quintals is sure to have the matter determined in his favour'-an observation which recalls Macaulay's essay on Bacon. In their capacity of judges the convoy-captains used to issue orders and edicts, ' of which,' says Larkin, 'there has not been any registry,' so that 'what one commander-in-chief hath confirmed the next hath vacated. I have prevailed with this' convoy-captain (I 7OI) 'to leave an abstract of all such as have been made during his time', whereby these pretorian edicts of the sea became perpetual, and the decisions began to mature into a code; began only, because the records were not continued, and twenty-seven years later similar records were introduced into Placentia by Lord Vere Beauclerk, who seemed to regard himself as their inventor. As soon as commandants were appointed they imitated their appointers when their appointers were away. They were as evanescent as the convoy-captains, and Gibson, Handasyd, Lilburne, Haven, Powell, Richards, Lloyd, and Moody succeeded one another in the first seven years. Of these imitation-governors, Handasyd provisioned the inhabitants in a time of want; and Lilburne charged fees for issuing warrants, and imprisoned or fined runaway servants and tyrannous masters, and, it being doubtful into whose pockets the fees and fines went, was recalled. The rôle of judging 'greiveiences . . . im abscent of the convoy' was thrust upon Powell $;^{1}$ and it was a rôle which neither his inclination nor his orthography qualified him to assume. Lloyd was the too-willing arbiter, and plied the stick too readily with his own hands. Under him legislation began, and he persuaded or forced the inhabitants - the better sort of whom were nothing loath-to bring timber for the fort and for the boom across the harbour-mouth $\left(1_{70}-4\right)$. He levied services, and not only services, but for spying purposes, as we saw, a subsidy or voluntary tax. He also exacted tithes in the shape of three

1 Captain Powell's dispatch, Oct. I2, I 702. 
quintals of fish per boat for the support of a minister, and it was whispered that these tithes went the way of Lilburne's fines. Both Moody and Lloyd organized the militia, with the consent of the militiamen, and Moody arranged (I 705) that twenty militiamen should keep watch and ward in the fort each night. In I $708 \mathrm{~A}$. Cummings was appointed by the home and a authorities custom-house officer, but having no Court or Executive to back him he merely held a watching brief.

Customs' officer

Captains Bridge (I 702) and Leake (I 704) inadvertently referred to the commandants of those years as Governors, and the title was a prophecy as well as a reminiscence. In I 709 existed.

Commandants acted as Goverthe regular officers and soldiers having been removed, the inhabitants elected commandants of militia at different places, nors when captains and amongst others John Collins as commandant at St. John's. In the same year Captain Taylour, R.N., having restored the forts at St. John's, confirmed this election, and conferred on Collins the title of 'Governor and commander in chief of the port and harbour of St. John's and all the sea-coasts between 'Ferryland and Carbonear Island'; with power 'to defend the fort, keep discipline, and order all the inhabitants into the said fort' with their provisions. Once more there was a resident Governor. He was only the deputy of an annual official, so that his functions would necessarily close with the year, and would be in abeyance during the presence of the convoycaptain, from whom he derived his authority. He was unpaid, and, like Lord Baltimore's Governors, ruled over a part only of the English settlements. In I 7 I I Captain Crowe, R.N., and a , as convoy-captain, summoned 'Courts', composed of the "Court' ships' captains, merchants, and chief inhabitants, which sat off I 7 I I. and on for two months, examined witnesses, imposed fishtithes for the chaplain, services on the work of fortification, duties to patrol the neighbourhood, and to keep watch and ward in the fort by twenties at a time, organized the 1,925 male inhabitants into companies, and ordered them into winter quarters at Ferryland, St. John's, Harbour Grace, 
Bonavista, Carbonear, and four other islands ${ }^{1}$ under their nine respective 'Governors'. The colony, which had coalesced from six or seven civil governments into one government, under one paramount Governor, resolved itself once more into nine military governments more or less subject to one Governor at St. John's. Collins, as before, was to be commandant and Governor at St. John's. Judicial grievances of the old familiar nature were also redressed. This was the first Witenagemot or Grand Inquest of the nation in Newfoundland, and a similar assembly met next year under the auspices of the then captain of the Convoys; after which the institution lapsed. No new soldiers arrived, nor did any military or constitutional events of importance occur until the Treaty of Utrecht was concluded in $17 \mathrm{r} 3$.

Under the The existence of two Powers in one island, which had Treaty of Utrecht France proved intolerable in ancient Sicily and modern St. Kitts, was deemed intolerable here; and henceforth the whole ceded Nerv- island passed under the exclusive sovereignty of England. but reserved fishing rights on the Treaty shore, I 1313 .

England became sole owner in fee-simple of the land. But fishing easements, which had preceded fishing settlements, were still preferred by the philosophers of England to more permanent and progressive kinds of colonization, and French subjects were allowed during the fishing-season a right to catch fish, and dry what they caught, in that part only of Newfoundland, which lies north of Cape Bonavista on the east coast and of Point Rich on the west coast. It was clear that this right was not exclusive, still less could it be construed as authorizing interference with the English settlers who had occupied Bonavista Bay north of Cape Bonavista since 1698 ; but considering that England had spent a century in illustrating its inability to hold the balance between nomadic English fishermen, who had fishing easements, and actual English settlers, who owned land and fished, it seemed unwise

1 Dildo and Fox Islands in Trinity Bay, Bell Island in Conception Bay, Gull Island between St. John's and Ferryland. 
to create a sphere, in which the fishing easements of nomadic French fishermen overlapped and must one day conflict with the rights of possible English settlers. But these tares did not injure the wheat-field until many years later. So far as Newfoundland was concerned the southern parts of the island, including Placentia, St. Pierre, and Miquelon, were wholly transferred to England, and it was impossible that the events of I 696-7, 1705, and I 709 could be repeated. Newfoundland lay only in a sequestered nook of the theatre of war; and elsewhere there was compensation, and compromise. Amongst other articles in the Treaty, Cape Breton Island was ceded in clear terms to France, and Nova Scotia in ambiguous terms to England; and during the next thirty years of profound peace echoes of the past storm, and avant-couriers of the coming storm, were heard from time to time along the coasts of North America, and troubled those who noted that new seeds of conflict between French and English had been sown by the short-sighted or sinister authors of the Treaty of Utrecht. But were they short-sighted or sinister? Or were they merely the mouthpieces through which an inevitable and universal weariness of war voiced itself? We have already arrived at the period when there were two parties in the State, when constitutional government began in England, and when constituents became a power; and when, though the division between East and West was healed and forgotten, and the new parties tended towards domestic peace, a new civil war between a Jacobite and a Hanoverian successor to Queen Anne seemed very imminent. It was untrue that these statesmen 'preferred far Th' unjustest peace before the justest war'; but it was true that after nearly a quarter of a century of war they preferred the possible to the perfect. 


\section{AuthoRities.}

There are descriptions of Placentia in:

Bacqueville de la Potherie, Histoire de l'Amerique Septentrionale, I 72I-2. First letter. He was there 1697.

(Abbé) Jean Beaudoin, Les Normands au Canada, Tournal de l'Expédition de D'Iberville, 1696-7, edited by A. Gosselin, 1900. $\mathrm{He}$ was with D'Iberville, 1696-7.

Jean de la Hontan, Nouveaux Voyages, 1 703, Letter xxiii and Memoirs. Its translation ( 1703 ) is edited by $\mathrm{R}$. G. Thwaites, 1905. He was there 1692 , and was King's Lieutenant there 1693 .

P. F. X. de Charlevoix, Histoire et Description générale de la Nouvelle-France, 1744, translated by J. G. Shea, 1872, vol. iii, p. 141, \&cc., vol. v, passim (see Index, 'Newfoundland'), and mainly based on above.

The copies of French Statistics, Orders of the King, \&c., referred to in the notes, were kindly shown to me by Dr. Doughty the archivist of the Dominion at Ottawa. Other statistics are contained in the Official Censuses of Canata, r665 to I87r, published as vol. IV of the Census of $1870-1$. Where there are trifling divergences in 1687 and 1691 I follow the printed statistics.

Edouard Richard's Supplement (I90I) to D. Brymner's Report (I899) on Canadian Archives calendars various French official documents relating to the French colonies in North America.

C. M. Andrews and F. G. Davenport, Guide to the MSS. materials for the History of the United States down to 1783 in the British Museum and Oxford and Cambridge Libraries, I908, is of assistance to historical research. 


\section{CHAPTER VI}

\section{A HALF-CENTURY OF PROGRESS, 1713-63. THE SECOND ANGLO-FRENCH DUEL AND ENGIISH VICTORY}

THE Treaty of Utrecht is the half-way house and turning- The history point in the history of Newfoundland. A period of two cen of Nerw. turies of continuous development forms both retrospect and is a history prospect; and these two periods split into two smaller periods, of four centuries each of a century and each with a character of its own. The and its visitors who came and went like tides and winds, and who em- half-way bodied the very spirit of mutability and anarchy, had the first Treaty of century to themselves. Their Being alternated with NotBeing; they lived like seals and thought like geologists; to I713. them Newfoundland was little more than a sunken fishingbank with a dry top here and there, and they left indelible traces of their genius on the place. During the next century a few small groups of settlers arrived who were imbued with ideas of permanence, home, and order, but they were overshadowed by the influences which were already there, and the shy wayside flowers were looked on as exotics when compared to the more garish, transitory, and luxuriant crops amongst which they grew. Time with its cradle and war with its winnowing-fan proved that the future belonged not to the annuals but the perennials. The proof was given at the close of the second century, but the whole of the third century was spent in mastering the proof; and during this third century the visitors became so unimportant, and the settlers so numerous, that it was at last unanimously recognized that Newfoundland, instead of being half colony and half fishingbank, was a whole colony like other colonies, and with a destiny of its own. The final recognition of this fact ushered in the fourth century of the history of Newfoundland. 
The wheels of the chariot of history moved very slowly as though tortoises were in the shafts, and it took three centuries to arrive at the starting-point of other colonial histories.

Before

I7 13 sett-

lers sur-

vived

nomads, and of the

two systems of settlement the fittest survived;

and Newfoundland came under one owner and was regarded as one with itself,

Other self-evident truisms were laboriously evolved at the close of the first period of two centuries, and the Treaty of Utrecht proved a landmark and signpost in the history of Newfoundland in more senses than one.

In the first century four nations fished, in the second century four nations fished and two of these self-same nations settled in Newfoundland; at the Treaty of Utrecht no other nations except the nations of settlers disposed of Newfoundland; and of the nations of settlers, the nation whose settlements were most widespread and spontaneous prevailed against the nation whose settlers were most orderly and organized. Nature overcame Art, and clumsy half-hearted defenders expelled spirited and skilful aggressors. The Anglo-French settlements left no room for the Spaniards and Portuguese, and the Anglo-French duel left Englishmen masters of the field. Thenceforth fate spun from a single European distaff. And thenceforth-if the metaphor may be pursued-one spindle was used. In Guy's, Lord Baltimore's, and even in Kirke's grants, Newfoundland was not regarded as one independent unit, but the subject of the grant was sometimes less, sometimes more, and sometimes both more and less than the island. The image was seen in part, or with a blurred or even double outline. The very convoy-captains patrolled the coast 'as far' only 'as Trepassey ' 1 and enforced regulations applicable only ' between Capes Race and Bonavista '.' The Act of 1699 for the first time anticipated rather than asserted, and the Treaty of Utrecht for the first and last time uncompromisingly asserted the unity of the island and of the Power that owned it. England was declared supreme over the whole island, and nothing but the island and its attendant islets. The nations

$$
1 \text { Ante, p. 72. } \quad 2 \text { Ante, pp. 72, 77, 97. }
$$


that claimed Newfoundland eliminated one another one by one until only one claimant was left; and the thing claimed was for the first time clearly conceived. Two centuries of labour were required to bring to the birth these crude and elemental ideas. Even then these ideas were not expressed whole-heartedly, for the eighteenth century at which we have arrived was an age not of chivalry but of sophisters and economists and calculators, not martyrdom but of self-interest of the other and good-humoured tolerance; and laissez-faire, laissez-aller nation. was its characteristic motto. Truth was clear, but the fight for truth was tiring, error had its uses, and 'private vices were public benefits'. Difficulties if left to themselves would resolve themselves, and incongruities had better be ignored; so statesmen who believed in the permanence and progress of English settlers upheld the vested rights of the vagrants, and perpetuated for another eighty years dual control by residents and fishing admirals, and allowed for the next two centuries French as well as English fishermen to haunt the northern and western shores of an English island. The shadow of French dominion survived its substance and hovered banefully over the remoter districts. The conflicting rights of English fishing admirals and settlers in the settled districts, and the prospect of a similar conflict between French fishing admirals and Englishmen in the yet unsettled districts, made political, economic, and social progress slow.

The third century of the history of Newfoundland began Domestic with a treaty $(\mathbf{1} 7 \mathbf{1} 3)$ and ended with a treaty $(\mathbf{1} 8 \mathbf{1} 8)$, and was ${ }_{\text {wiill be dis- }}^{\text {History }}$ divided into two half-periods by a treaty $\left(\mathrm{I}_{7} 63\right)$, but it had cussed first, already begun to display microscopic germs of constitutional ${ }^{1713-63}$. development, and its domestic history must be narrated before its foreign relations are discussed.

The jurisdiction of the fishing admirals over fishing dis- fustice was putes rested on immemorial custom, upon which the Star ispensed Chamber (1634) and Parliament (1699) only set a legislative ominally seal. But custom limited their jurisdiction to fishing-ships'admirals 


\section{II2 HISTORICAL GEOGRAPHY OF NEWFOUNDLAND}

but really crews, and the provisions of $1634-99$ extended it to disputes by the convoy-capbetween fishing-ships' crews and shipless fishers from the tains, shore. This extension was only tolerable so long as the judges observed the forms of justice and the nomads outnumbered the settlers. But the judicial qualities of the admiral-judges made angels weep and convoy-captains laugh. The admiral-judges had been ordered since 1670 to keep journals ; but 'few admirals', said Captain Graydon (I70I), 'are capable of keeping journals'. They were 'illiterate and in this respect very indolent men', said Lord Vere Beauclerk (I730); so that journals were never written because the journalists could not write. Nor were their moral superior to their intellectual qualifications. Captain Lee ( $173^{6}$ ) described them as 'very often very ignorant and very impudent fellows'; Captain Falkingham $(\mathrm{r} 7 \mathrm{r} 6)$ as 'a nuisance to the country, ... making their authority scandalously subservient to their interest'; and the almost annual reports of the convoy-captains between 1675 and 1757 almost invariably reiterated Captain Taverner's accusation (I $1 \mathbf{I}_{4}$ ) that 'the admirals were seldom or never at leisure to hear any complaints whatsoever except one of their favourites' or one of themselves 'was a party'. The convoy-captains met this absurd condition of affairs by an ingenious device. They were made Judges of Appeal by the act of I699, and in order to save expense ran the Court of Appeal and Court of First Instance into one Court over which they and the 'admirals' jointly presided, but as they had power to reverse the decision of the 'admirals', they treated the admirals as advisers only. Lord Vere Beauclerk's apology for this odd arrangement $(1728)$, that 'unless the captains of the men-of-war are present to assist them at their Courts their meetings would be nothing but confusion and their orders of no use', is itself odd, but throws a new light on the origin of assessors.

Lord Vere Beauclerk added that the habit which the 
convoy-captains had 'of publishing orders in our own names rvinter, to prevent disorders' in the winter was universal. Their annual absences forced them beyond the judicial into the legislative sphere; and this usurpation was legalized by an Order in Council passed in 1728 , and constituting the moreorless, convoy-captain Governor. From 1729 until 1817 Newvere called Governors, 1728 , and became triennial foundland had Governors who were sometimes quinquennial (I764-68), quadrennial ( $1813-16$ ), or biennial, but were usually triennial (I729-3r, I 735-37, I 750-2, I 757-9, I769-7r, et seq.), and were very seldom annual, as the convoy-captains used to be before 1724 , so that personal ties were formed between Governors and governed. But down to 1817 , although for some purposes their office was continuous, they were also captains of ships who had to sail backwards and forwards within the year; and, like the arctic sun, they shone only during the brief summer season, and in their absence the sky was moonless, and for a while unillumined by a single star.

Various efforts were made to redeem winter from its Local dedarkness. In $\mathbf{I} 7 \mathbf{I} 7$ the convoy-captain was ordered to reportputies were the name of a suitable winter resident as deputy governor, for winter, but he replied that there was not a man in the island fit for the I 7 I7, I 7 I9. post-no, not one. His successor in 17 I 9 favoured the idea of appointing as Justices of the Peace several winter residents, among whom W. Keen, a resident of fifteen years' standing, who had recently served as a Commissioner in a special Court convened at St. John's to try crime committed on the high seas, was pre-eminent. But this idea was rejected for the nonce as illegal. In $\mathbf{I}_{723}$, fifty-one leading men at St. John's, inspired by Locke's Treatise on Civil Government, signed a document $A$ State which recited that men emerged from a state of nature into a political society by contract, and in which the signatories bound themselves by bonds to elect three rulers every year resting on social contract was when the convoys were away, and to abide by the decision of the majority of electors. The three first magistrates of this 


\section{II4 HISTORICAL GEOGRAPHY OF NEWFOUNDLAND}

artificial State were the chaplain (named Jago) and two leading residents (named Southmead and Rook); and they held 'Courts', destroyed dangerous chimneys, whipped a servant who spat upon his mistress, and enforced contracts and rights of way. But this experiment was not repeated; otherwise St. John's might have been transformed by the ideas of an English philosopher into the semblance of some city of ancient Greece, in which all powers sprang from and resided in a few original fathers and householders, with three short-lived archontes as their deputies, and with some two hundred Then Jus- unrepresented bachelors as their helots or metics. In 1728 tices of the Peace were appointed and made deputy Governors during winter, I729. W. Keen, who had been ordered by the convoy-captain to report disorders, arrested and sent a murderer to England at his own expense. ${ }^{1}$ In 1729 the first resident Justices of the Peace were appointed under the sanction of law by the first Governor, a prison-rate was levied, and prisoners' stocks were built at St. John's and Ferryland. Keen, Weston, and Southmead were the first Justices for St. John's and its neighbourhood, and they controlled seven constables. Similar arrangements were made in five other districts. If Rip van Winkle had gone to sleep in 1629 and awakened in the winter of 1729 , he would have fancied that the six colonial Governors whom he knew had been transformed in one night into Justices of the Peace, who reigned over six districts which were a little larger than those of yesterday, in order to compensate for their diminished glory.

Courts of Between 1729 and 1763 a Court and Judge of ViceLaw were instituted, 1729 to Admiralty ( 1737$),{ }^{2}$ a naval officer $\left(\mathrm{I}_{741}\right),{ }^{3}$ a Criminal Court of Oyer and Terminer-with five local Commissioners instead of a judge ( $175^{\circ}$ et seq.), -and a Custom House ( 1762 ) came into existence. Special Courts with Vice-Admiralty

$1 \mathrm{He}$ also did so in $\mathrm{I} 720$ and 1730 .

2 Captain Lee's dispatch, Sept. 21, I 737 .

3 Captain Thomas Smith's dispatch, Dec. 19, I 74I. W. Keen, junior, son of the W. Keen, was N. O. 1742; Captain J. Byng's dispatch, Feb. 22, I743. 
jurisdiction had been summoned at St. John's in I $70 \mathrm{r}$ and on one or two other occasions, and a permanent ViceAdmiralty Court had been promised to Cummings in 1708 ; but the combination of Custom House and Vice-Admiralty Court was not realized until after the Treaty of Paris. Among the earliest judges of the Vice-Admiralty Court the names of W. Keen and M. Gill are conspicuous, and the Commissioners who officiated as co-judges in the Criminal Court were usually the six or seven best magistrates in the colony, like William Keen, Michael Gill, and Nathaniel Brooks.

In 1754 nine persons were tried for the murder of W. Keen, who had succeeded Collins some thirty years previously as the natural leader of the colony. The murder was the act of ten conspirators and was committed for purposes of burglary, but probably the ringleader was also actuated by revenge for sentences inflicted by the murdered magistrate for petty crimes. One of the murderers turned king's evidence, and all who were tried were found guilty. Four of the condemned persons were soldiers in St. John's garrison. Four were executed, and five were ordered to be detained during the King's pleasure, but were subsequently respited and allowed to leave the colony. About the same time transportation elsewhere than to the United Kingdom was inflicted on other criminals. Thus, at the close of the half-century which we are reviewing, five institutions more or less represented the State-summer Governors, nominally annual but virtually more or less triennial; Justices of the Peace for the whole year, nominally annual but virtually permanent; special Commissioners of Oyer and Terminer, who usually held sittings once a year; and a more or less permanent ViceAdmiralty Court and Custom House.

Between $\mathrm{I}_{7} \mathrm{I}_{3}$ and $\mathrm{I}_{763}$ equally important industrial At St. changes occurred. St. John's was transformed from a fishing- John'slarge village into the semblance of a commercial town. In the merchants, background were big capitalists who were as yet too few to 
compete with one another, and Admiral J. Byng complained that three or four merchants in St. John's boarded vessels which arrived, bought up everything, and engrossed all the trade ( $\mathbf{I}_{\mathbf{7}}$ 2). Next came a landlord and shop-keeping class, which lived without fishing and by giving credit and lending to fishermen.

and little capitalistic boat-owners monopolized the shore fisheries, driving European fishingvessels arvay from the shores,

'The inhabitants of St. John's', wrote Captain Percy, 'have left off keeping of boats and servants for fishing. They live by letting out their stages and keeping public-houses. Here are a nest of little pedlars who goes $(s i c)$ under the denomination of merchant factors, have small store houses, inhabit among the planters all the winter, and involve them over head and ears in debt' $(1720)$. The prevalence of traders at the capital was due to economic causes. It paid better for producers to stick to production and the traders to stick to trade. 'The nest of little pedlars' was due to the superiority of innumerable small boats worked by their owners, over the boats of absentees. According to Captain Percy, five men in a boat, with hired stages, caught one hundred quintals more fish than the hired boatmen of a rich inhabitant who owned houses and stages and lived and peddled on shore. The small, self-interested capitalists not only drove the traders but the shipowners away from the inshore fisheries.

The fishing admirals and captains' have left off keeping of shallops and fishing near the shore... but send their ships and vessels on the Banks for a month or five weeks', neglecting, as Captain Lee added, their judicial duties ( $173^{6}$ ). Captain Lee might have also added that they lost their former fishing-posts upon the shore; because, although the Act of I 699 allowed them to occupy posts wherever they had occupied posts since 1685 , no record was kept of where those posts were, except in the fleshy tablets of the fishermen's minds, and fishermen's memories could only be kept fresh by continuous use ; whilst settlers, forgetting what it was not their interest to recollect, began to encroach upon the seaside. . In 
I 720 Governor Collins, as he was still called, was chief amongst those who encroached, so that encroachment became almost a badge of respectability, and the shipowners being absent on the Banks began to forfeit their claims upon the shore.

Fishing on the Great Banks of Newfoundland, a hundred on to the miles east of St. John's, was a new departure in English $\begin{gathered}\text { Grand } \\ \text { Banks. }\end{gathered}$ history, and at first it was unsuccessful. Residents took no part in it, and the English fishermen were slow in learning how to treat fish caught so far away, so that 'the consuls and the merchants residing in Portugal, Spain, and Italy unanimously complain of the ill-curing of the fish in Newfoundland for some years ' (I 728$)$. $^{1}$ The years of transition which succeeded the war were about as lean as the years of.war, but before the middle Twenties fat years began again, and in $175^{2}$ the English fishing-ships numbered 284 and averaged I 20 tons, against 221 ships averaging 74 tons in the most prosperous years of the past century. ${ }^{2}$ Moreover, they were twice the size of the New England trade-ships which visited the colony, and the old Englanders employed seventeen men, while the New Englanders employed seven men, on a ship. Long voyages still made big ships and many sailors, and the English fishing-ships gained steadily in weight and number, at the very time when they were being ousted from the shore by competitors, whose industrial progress was still more rapid and striking.

Bay fisheries became boat fisheries, and some of the boat- $A$ wageowners were settlers, but many of them came as 'passengers' and-truck from England, with servants who were hired for two summers became and a winter, and without boats, which were left behind or general in hired in the colony. The relation of the ship-owners and fisheries, boat-owners to their merchant was the same; and in both cases the merchant was the only possible purchaser of cod, and the only possible vendor and lender of victuals, tackle, 
and other necessaries, for which he claimed a lien on the year's catch, everything from Governors down to liens being annual in the colony. The relation of the ship-owners and boat-owners to their employees was different. Ship-owners paid their employees part profits; but profit-sharing began to be regarded as an anachronism in the inshore fisheries. Captain Lee wrote: 'the ships from Bideford and Barnstaple are the only ships that go on shares with their companies now' (1735); and that these ships sought new shores in Placentia Bay, while other similar ships sought new seas on the Grand Banks. The new industrial system drove the old system out into the ocean, or else into unfrequented nooks and corners. Under the new system three partners owned a boat and had two employees, whom they paid in fixed amounts of cod or of merchant's bills, both of which were only convertible into necessaries at the merchant's store; or else of 'necessaries-which is generally rum at a very extravagant price'.' If the payment was made in cod, it was clear that the employees were still part-owners and profit-sharers, taking an invariable instead of a variable share of the produce of their fishing; and if the payment was made in bills or necessaries, it was equally clear that the employer only meant to repurchase the employees' share of the produce at a valuation. The authors and actors in the new system were only conscious of substituting certain for uncertain profits, but contemporary commentators described the new system as the substitution of wages for profits. In many respects the new system of certain profits resembled a wage-system in which rum was the wage-fund. Moreover, the fixed price was reckoned, although it was never paid, in money; and its money value was assessed at from $£_{7}$ to $£_{25}$ a season. Further, the employees from England bore a nearer re-

1 So Lord Vere Beauclerk, Sept. 26, 1 730. Compare Captain Percy, Oct. 13, I720; Captain Bowler, Oct. 9, I 724 ; St. Lo, Nov. 15, I 727 ; Captain Lee, Sept. 29, 1735 . 
semblance to free wage-earners than any other class in any other colony in that century. If they stayed in the colony they soon merged themselves in the class of boat-owning employers, who also sometimes acted as employees; but having once sold their labour to a high bidder, and having learnt the advantages of mobility, they often went further and fared better. Ever since 1660 anathemas after anathemas were hurled against New Englanders for 'stealing away' sailors, who went to Newfoundland from England, and ought to have returned but did not return to England. In modern language, this meant that the English sailors regarded themselves as wage-earners, that higher wages were paid in Newfoundland than in England, and in New England than in Newfoundland, and that labour was beginning to respond to the laws of supply and demand. In the eighteenth century efforts were made to compel and to punish as well as to anathematize; but it was in vain that men warred against the laws of Political Economy.

In the early years of the eighteenth century New Eng-and efforts landers, who used to bring provisions both solid and liquid to prevent to Newfoundland and had all the American carrying trade in wagetheir own hands, were ordered to execute, and invariably going to executed bonds not to take passengers from Newfoundland to New EngNew England, but invariably violated these bonds with perfect land. impunity. At the close of the season of I7 I9, Captain Ogle resolved to suppress the trade once for all, and contrived a masterstroke of policy, ordering all the New Englanders to sail out of St. John's under his convoy, when he sailed home. To his surprise they cheerfully obeyed. Then the convoyers and convoyed parted company, the former returning to England to report that the illicit traffic was at last finally stamped out, and the latter returning to St. John's to crowd their ships with forbidden passengers. ${ }^{1}$ After Ogle's masterstroke had failed, these dead-letter Ordinances of the Little

1 Dispatch of Captain Percy, Oct. I3, I 720. 
Englanders became as obsolete and hypocritical as they were impotent. In the seventeenth century homeward fares were half as much again as out fares, so that it paid men not to go home. The laws, such as they were, were honestly meant to prevent a real harm (or good). But in the eighteenth century out fares were half as much again as homeward fares; therefore cost did not prevent English sailors from returning, and no one wished the return of those who did not return. A new and unprecedented demand to emigrate, which arose in the eighteenth century, more than doubled the price of the out fares; and the new demand came from Irish Roman Catholics, who rarely wished, ${ }^{1}$ and whom statesmen never wished, to return.

Irish wage- The Irish policy of the eighteenth century was in itself earners swarmed to Newfoundland and became three-parts sham. Anti-Catholic laws were passed which were directed not so much against Roman Catholicism as 'against the industry and property of whoever professes that a danger, Religion'.2 Under a law of 1696 colonial goods might not be imported into Ireland; and under a law of I 699 manufactured wool might not be exported from Ireland. Scotland was allowed, but Ireland was still forbidden, to vend European goods except provisions to the colonies; and raw Irish wool could only be exported to England. Ireland was throttled, mutilated, and bound hand and foot. Non-Celtic Ulstermen shook Irish dust from their feet and angrily settled on the American continent. Famines ensued which Swift, Berkeley, Boulter, Sheridan, and Skelton described in words that burn; and famine was the scourge that drove pitiful hordes of Celtic-Irish peasants to Newfoundland, which was the only place in the New World where their kith and kin could be found. Even there they were unwelcome guests. Captains Percy (I720), Beauclerk (I728), Clinton (I73 I), Lee (I 735), Smith (I74 I), Byng (I743), Townsend

1 So Captain Watson, Nov. 27,1748 .

2 A. Young, Tour in Ireland, vol. ii, p. 55. 
(I 747), Rodney (I 749), and Drake (I 752) expressed alarm at their numbers and at their refusal to take oaths of allegiance, or rather abjuration. Captain Drake pointed out with dismay that they were half the inhabitants of the colony, and that in St. John's Irishmen and Englishmen fit to bear arms were nicely balanced, the former preponderating in 1747

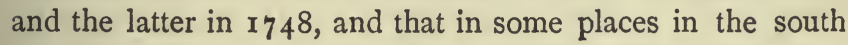
the Irishmen were in a large majority. The Protestant Succession was not assured; and French priests were never far off, so that the political danger was not pure illusion, and assuming that it was illusory there was a very real social danger from Irish criminals. Drunken brawls between Kelly, Murphy, Doyle, Quinn and other Irishmen, were frequent; and all, or nearly all, the murderers of W. Keen bore Irish which was names. At one time convicted felons were preferred to Irish- increased men; thus in I73I Captain Osborn wrote that 'it is now presence of become a practice of masters of ships to bring over here trans- transported ported felons instead of Irish servants', and Captain Clinton enclosed a petition in which the petitioners 'represent the danger we are exposed to by the transportation of felons from Great Britain hither, which before this year hath not been known, and since which five of the basest and most barbarous murders have been committed, not without strong suspicion of its being done by some of them, one of whom is at this time in prison for theft' $\left(\mathbf{I} 73^{I}\right)$. But out of evil good came, and convicts and Irish criminals were the first cause of Criminal Courts being instituted.

New industries of a watery character were developed, and Seal-catchsealing became an industry instead of a pastime, bringing in ing and $f_{4,000}$ in 1720 and $f_{3,379}$ in 1735 . Trinity and Bona- began, vista Bays were the principal places where seals were caught; I ${ }^{200}$, Saland a district north of Bonavista Bay was for the first time ${ }_{1722, \text { Fogo }}$ occupied by fishermen, sealers, and salmon-catchers. The and Twilnorth coast of Bonavista Bay had been inhabited as early as lingate, I698, and George Skeffington had made the district famous occupied. 
or infamous by his surrender of his post to the enemy in I705. The peaceful pioneer of this new movement to the north of Bonavista Bay was the same George Skeffington, who, according to his account, had spent twelve years, between I 708 and I 720 , and had employed thirty servants from time to time, in improving the salmon-fisheries north of Cape Bonavista, and clearing some forty miles of wood. Even his peaceful victories over Nature were tainted. He had been recently financed by W. Keen, who joined him as partner in a plan to improve the salmonries at Gander Bay, Dog Bay, and Ragged Bay in $17 \mathbf{1 8}$, and Keen persuaded Captain Scott to grant a protection order to Skeffington as trustee for the partners (I 7 19), immediately after which the trustee disclaimed his trusteeship and pocketed all the profits ( 1720 ). There were no Frenchmen in the neighbourhood, but there were other dangers and annoyances. In 1724 one of Skeffington's men was killed by Boethics; in 1725 Captain Bowler caused Englishmen who disturbed the salmonry to be whipped-a new, but effectual method of vindicating rights of property; and in 1729 Skeffington sold his concession to an extended partnership. In $\mathbf{1 7 2 9}$, out of nineteen magistrates Bonavista and districts north of it possessed three magistrates, and the northernmost settlers concentrated during winter on the islets of Fogo and Twillingate, which figured in the statistical reports of $1733^{1}$ for the first time. This northward extension was not only important in itself, but important as having been promoted by a brand-new industry which had nothing to do with the sea. Similarly, salmonfishing led to the occupation in $\mathbf{I 7 2}_{3}$ of Salmonier and its neighbourhood at the head of St. Mary Bay, so that Englishmen were beginning to fill up the gap between Trepassey and what was formerly the French zone.

Residents began to balance non-residents.
Residents grew apace, as the increase of women and children from 612 in $1710^{2}$ to $1,35^{6}$ in $173^{8}$, and to 2,508 in

1 Dispatch of Lord Muskery, Sept. 29, 1733.

2 Ante, p. 103. 
1754 attested. Heads of families accounted for a third more, so that in round numbers permanent residents were 800 in $1710,{ }^{1} 1,800$ in 1738 , and 3,400 in 1754 . The ships' crews of English ships, for whose sake the older theorists taught that the fisheries primarily existed, numbered 3,600 in $\mathbf{I} 73^{8}$ and 4,500 in 1754 , so that they outnumbered residents, in the strictest sense of the word residents. But if residents included all those who wintered in the island, they outnumbered ships' crews during this half-century. On the other hand, if passengers were added to ships'crews, the visitors outnumbered the settlers, except when there were war scares. ${ }^{2}$ So far as figures went a devotee of the divine rights of majorities to rule minorities might hesitate whether to sacrifice the settlers to the visitors or the visitors to the settlers. The problem, when regarded from this point of view, was puzzling. As before, both classes lived only by fish and trade. Cattle were 300 , sheep 600, swine 300 ( 1738$),{ }^{3}$ and 'improved land' less than a square mile ${ }^{4}$; so that farming was stationary, and the visitors and settlers were rivals whose interests being similar were mutually repulsive.

The very soldiers were drawn into the prevailing industrial currents. In 1714 Placentia was occupied by four independent Companies raised in Ireland and commanded by Colonel Placentia was garrisoned, Moody, the hero of 1705 , who was made 'deputy governor of the Fort' under the Governor of Nova Scotia, who was also Governor of the town and garrison of Placentia. The Governor of the town neither visited nor governed it, and the garrison was for practical purposes under the independent control of Colonel Moody and his successor, Colonel Gledhill. Except in military matters-an exception which was removed in 1729-the convoy-captains ruled over, and the Act of 1799 applied to the town of Placentia as much or as little as to the town of St. John's. As in Acadia, the
1 Ante, p. 103.
${ }^{3}$ Comp. ante, p. 83 .
2 e.g. $1745,1746,1757$.
e.g. 516 acres in 1741 . 
and a ferw Frenchmen who took the oaths were allowed to retain or sell Frenchmen their possessions. Contemporary observers computed that chiefly on 100 families left Placentia for Cape Breton Island, but that St. Pierre three remained, and with them some 50 or 60 unattached
Island, servants, whom Moody sent into the woods to hide from those who wished to transport them. ${ }^{1}$ Captain Taverner wrote $\left(I_{7} I_{7}, I_{7} 18\right)$ that there were $\mathrm{r}_{5} \circ$ French houses and only three French families in Placentia; that west of Placentia Bay there were 25 settlers with 66 women and children and 228 servants; that 17 of the 25 had taken oaths of allegiance; that $\mathrm{I}_{5}$ of the $\mathrm{I} 7$ belonged to St. Pierre; that none of the I7, except four or five in St. Pierre, wintered under the English flag; and that the rest lived a double life, their souls, bodies, and personal property being in Cape Breton Island, and their land and houses in Newfoundland. He had surveyed all the French coast-line, with its fifty odd coves and creeks, from Cape St. Mary to Chapeau Rouge, and from Chapeau Rouge to the westernmost tenements in or near Hermitage Bay; and, if Placentia and St. Pierre were excepted, he had only found a few settlers at Boboy, near Burin, and six or seven elsewhere, ${ }^{2}$ and rather more than twice that number of vacant houses. ${ }^{3}$ All his contemporaries corroborated Taverner in describing St. Pierre Island as the centre of French activity, instead of Placentia, where only one French family resided in $\mathbf{1 7 3 0}$. France had run its race on the mainland of Newfoundland. The French colonists, according to Taverner, had a fine forest on the coast west of Hermitage Bay, and natural pastures on Miquelon Island and near Chapeau Rouge which they had neglected; but

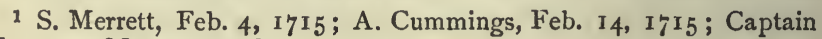
Taverner, May 20, I 718 .

${ }_{2}$ Mérichon Island,Égeron.Island, Boboy, Corbein,Little St. Lawrence, in Placentia Bay (west coast); 'Beach', near Fortune; and Bandalore (Belleoram), where Belorme had wintered twenty years.

3 In Cumin's Harbour (Paradise Sound), Port Ovray (?) (south of Little Mortier Bay), and Great Burein, in Placentia Bay (west coast); Grand Bank, near Fortune; Bandalore (v.s.), Duck Bay, Cape Nigro (Connaigre), Isle d'Espère, and Hermitage, in the Hermitage district. 


\section{A HALF.CENTURY OF PROGRESS, I713-63 I25}

he praised two rye-fields at Connaigre (Hermitage), and wrote that he saw on the islet of Egeron a French Ariadne whom her Bacchus had deserted, and who had 'a good stock of sheep and goats. In her garden was the largest and heaviest ears of wheat that ever I saw, besides cabbages and root-crops'; so that Frenchmen, like Englishmen, looked on agriculture in this region as a branch of horticulture. Frenchmen from Cape Breton Island used to seal in 'Bay de NorthEast' and other coves apparently in Despair Bay, otherwise French civilization did not extend west of Hermitage Bay. But in 1734 Captain Taverner discovered almost by accident a detached 'little Commonwealth' of French 'men, women, and children' who had 'deserted from Cape Breton and settled in Port Basque near Cape Ray', who drew supplies from ships which came from Bayonne and the French Basque port of St. Jean de Luz; and who were very few and very poor. These waifs and strays took oaths of allegiance and soon disappeared. From time to time we hear, also by accident, of French-Indian parties from Acadia hunting in midwinter year after year near Cape Ray, ${ }^{1}$ a practice of which we have noted possible traces in or before $1662,{ }^{2}$ and the evidence so far as it goes proves that with these exceptions the southwest coast was uninhabited and unvisited. ${ }^{3}$ French settlers melted away and became more and more intermittent during or immediately after the war, and were ultimately replaced by Englishmen; but for a long time no English settlers arrived in their place and the colony was the fort of Placentia. The identity of colony and fort, and the isolation of Placentia produced a curious economic situation.

Until after I720, no English fishing-ships sailed to The garPlacentia ${ }^{4}$; Placentia was 'of the least consequence to the rison of fishermen of this land, it lying far out of the way, 5 ; and Placentia

1 Captain Taverner, Reports, May 20, 1718 ; Feb. 5, I734. ing and

2 Ante, pp. 29, 79.

${ }^{3} \mathrm{La}$ Hontan, Voyages, ed. by Tbwaites, p. 332.

* Dispatch of Captain Scott, Nov. I718.

${ }_{5}^{5}$ Dispatch of Captain Percy, Oct. I3, I720.

trading ; 
arriving Colonel Moody was faced with a general mutiny, because his men had no beer. So the Colonel believing, as he said, that 'their drinking only water thawed from ice would infallibly have killed most of the garrison', bought molasses wholesale from the ubiquitous New England ships, and successfully quenched the mutiny with calibogus. During the next four years no clothes arrived, and the soldiers ' are now in a manner naked' ( $17 \mathbf{y} 7$ ), but this want was less serious and only evoked mild murmurs. Year after year down to 1726 the deputy governor had to keep the garrison, the settlers, their wives and their children from perishing, as best he could, and in 1725 there were not two settlers in Placentia who had not been fed by his bounty. One of two things was inevitable-starvation or wholesale trading; and the deputy governor was the only man who had credit. As in New South Wales seventy years later, the deputy governor adopted the second alternative. He became the only merchant, 'the only banker'-whose reserve was a floating security called rum-and 'the only shop', besides keeping ' cattle, poultry, and a dairy'. The reports from which these quotations are taken were dated 1726 and 1727 , for it was not till then that the home authorities knew what was being done. In I 720 Colonel Gledhill, who had recently succeeded Colonel Moody as commandant, urged that his soldiers, who had been reduced to a single company of forty men, should be employed on making a road from Placentia to St. John's. His suggestion, being a century before its time, was refused; and its refusal made him throw himself so energetically into the rôle of trader, that English fishing and sack ships began then to come. In 1727 forty-one English ships arrived in traders and Placentia and St. Pierre-half from Bideford and Barnstaple, came, which had now lost their old shore fisheries on the east; a quarter from Jersey and Guernsey, which seem to have succeeded the French vessels as purveyors of French brandy; and some from Poole, which was also busy on the new 
fisheries at Fogo. The ball was set rolling, and the military monopolist who communicated the original impulse was recalled, because as a trader he was already more of a nuisance than a necessity, and as a soldier he sinned against military law. The prosperity of Placentia advanced by leaps and bounds; in 1749 and $\times 75^{1}$, chiefly owing to an influx of Irishmen, the settlers and hangers-on of Placentia outnumbered those of St. John's; and shortly before the great war (I 742) Captain Taverner estimated the fishing-boats of Placentia and Fortune Bays at one-fifth of all the fishing-boats in Newfoundland ( 1739$){ }^{1}$

The garrison still languished. In 1730 its acting com- and the mander was a Lieutenant 'confined to his bed by age and $\begin{aligned} & \text { garrison } \\ & \text { languished. }\end{aligned}$ infirmities'; in $173^{6}$ its men were 'old men fit for Chelsea only' and destitute of small arms; and in 1745 Colonel Gledhill's son wrote that 'it was hard in such a dismal climate as this where nothing grows to see the King's troops naked'. After 1745 Placentia was no longer an utterly isolated garrison and its woes ceased.

In 1734 the convoy-captain urged the re-fortification of St. John's St. John's, which had had no regular soldiers since the catastrophe of $\mathrm{r} 709$, and had been denuded of its last guns in $\mathrm{I} 72 \mathrm{I} ;$ fortified, $_{174 \mathrm{r} \text {. }}$ and its re-fortification was decreed in $\mathbf{1} 740$. In $174 \mathrm{I}$ the Governor, Sir T. Smith, called the inhabitants of St. John's together, persuaded them to make a fort, organized a militia of Protestants, and left behind him ten guns in the charge of the militia and of some 90 marines, who were relieved by regulars in 1745. Thenceforth a Lieutenant-Governor of Placentia Fort guarded Placentia with some 45 regulars, and the Lieutenant-Governor of St. John's had under him detached units at small forts erected on Boys Island (off Ferryland), on Carbonear Island, and in Trinity Harbour, besides 320 militiamen with M. Gill as their Colonel.

1 Total boats $=1,118:$ Placentia, Burin, St. Pierre, and the Western Fisheries $=\mathbf{2} 30$. 
St. John's was taken andretaken during the next war, I 742 to r'63.

The second great Anglo-French duel for the possession of the North-American colonies broke out in 1742 , and but for a more or less lucid interval $\left(\mathbf{I}_{748-56)}\right.$ lasted until the Peace of Paris ( 1763$)$. The full fury of the storm broke on Acadia, Cape Breton Island, and Quebec, and only its distant mutterings were heard in Newfoundland. Newfoundland was once more a cave of shadows and echoes from the real world. As the storm arose Duviviers sailed against Placentia, and was driven back by contrary winds ( $\mathrm{r} 744)$; so that this danger passed away. ${ }^{1}$ And once more, while the storm was subsiding, the shadows assumed substance and the echoes became a voice. Late in June 1762 four French warships under Count d'Haussonville seized Bay Bulls, St. John's, Trinity Harbour, and Carbonear Island, all of which surrendered without resistance. Captain Douglas, of H.M.S. Syren, sent word to Lord Graves, the Governor, who was then on his way to Newfoundland. Lord Graves, after making preparations for the defence of Boys Island and Placentia by marines, sent word to the military authorities in New York. Colonel W. Amherst was promptly sent to the rescue from New York, landed in Torbay with soldiers slightly inferior in number to their antagonists; seized Quidi Vidi, Signal Hill, and St. John's; and on September 20 the whole French army, 700 or 800 strong, capitulated, but the French navy escaped in a fog.

Under the The war was terminated by the Treaty of Paris ( 1763 ), Trealy of Paris St. Pierre and Miquelon became French again, and French fishing easements on the Treaty shore were renerved. under which Canada, Cape Breton Island, New Brunswick, and Nova Scotia became English, and the French regained St. Pierre and Miquelon, which they undertook not to fortify but to occupy for the purposes only of the French fishermen. French fishing-rights were conceded in the Gulf of St. Lawrence, but not within three leagues of the coasts thereof or of any British island therein, or within fifteen leagues of Cape Breton Island; and the fishing and drying rights between 1 W. Bollan, Ancient Rights to the American Fishery, 1764, p. 55. 
Cape Bonavista and Point Rich on the coasts of Newfoundland, which were conferred in $17 \mathbf{I} 3$, were renewed, although in 1763 English settlers were in occupation as far north as Twillingate, and French fishermen had never during the last thirty years been further south than Fleur-de-Lys and White Bay, which were quaintly described as 'some ten leagues further north' than Twillingate. It was agreed, too, that Spanish fishing-rights, as to which there was an ambiguous reference in the Treaty of $\mathrm{I}_{7} \mathbf{1}_{3}$, did not exist.

In England during this period the country oscillated between a peace party and a war party; Pitt was the champion of the war party during the preceding quarter of a century, and in 1763 Pitt was dissatisfied with the Treaty on the ground that 'exclusive fisheries' were worth trying for ' for another campaign or two'.' 'Think nothing gained,' he cries, 'till nought remain'; but his wish was vain, for the world was weary of war, and the popular tide set irresistibly towards Peace, which was acclaimed with universal enthusiasm.

The Calendar of State Papers has not been continued beyond I 700 , consequently all the references in this chapter are to the MS. records in the Record Office. These records, 1696 to 1757 , were formerly entitled respectively, vols. iii to $\mathrm{xv}$ (inclusive) of the 'Board of Trade, Newfoundland ${ }^{3}$, but their titles are now changed. The writer was not allowed access to any original records of a date later than 1757 .

${ }^{1}$ Horace Walpole, Memoirs of the Reign of George III, vol. i, p. 228. 


\section{CHAPTER VII}

\section{THE THIRD ANGLO-FRENCH DUEL, AND ENGIISH VICTORY; AND THE BEGINNINGS OF PERMANENCE, 1763-1818}

The next half-century witnessed two great wars I $775-83$, I $79.3-1815$ and two important treaties, or groups of treaties.
THE diplomatic and military history of the ensuing halfperiod (r 764-1818) may be briefly outlined. There were two great wars. In 1775 war broke out between England and the American colonies; France (1778), Spain (1779), and Holland (1780) joined the colonists, and England faced the world in arms. It was primarily a civil war between the mother country and its colonies, and the adherence of France, Spain, and Holland did not alter its essential character. Its centre of gravity was in the New World. In I 783 American Independence was recognized, the Treaty of Versailles was concluded, and the war ended. Between $\mathrm{I}_{793}$ and $\mathrm{I}_{\mathbf{1}} \mathbf{5} 5$ the third and greatest Anglo-French duel occurred. Like the two previous duels $\left(\mathbf{r}_{689-1} 7 \mathrm{r}_{3}, \mathrm{I}_{742-63}\right)$ it exceeded twenty years in its duration; it was divided into two unequal parts by a Treaty, which is known as the Treaty of Amiens (1802-3), and it was essentially world-wide in its scope. In this duel France faced the world in arms, and England was only protagonist ; its centre of gravity was Europe, and the adherence of the United States to the enemies of England (18I2-14) was only an incident and addition to the original war. Peace was concluded by the Treaties of Ghent $(1814)$, Paris ( $\left.18 \mathrm{r}_{4}\right)$, and Vienna $(\mathrm{r} 8 \mathrm{r} 5)$, and by a convention with regard to the American fisheries (1818). England gained South Africa, the Indian Ocean, and undisputed supremacy in India; while France and the United States gained, or regained fishing-rights upon the coasts of British North America and Newfoundland similar to those which had been 
conferred by the Treaty of Versailles. The question of the fisheries became menacing soon after .1763 .

Immediately after the Treaty of Paris ( 1763$)$ was signed, The Treaty there was a collision, or an apprehended collision, between of Paris French and English fishermen in Newfoundland. The questions English home authorities strained the Act of 1699 in order as to jurtion and to avert this danger, and instructed the Governors of New- the right to foundland to prohibit 'exclusive possession'-in other words, settle on the settlement by Englishmen along the Treaty shore (1 764$)$. Coasts, Nothing was said about fishing-rights, which were presumably concurrent, or about jurisdiction, except that Englishmen were not to interfere in disputes between Frenchmen and Frenchmen. ${ }^{1}$ Palliser, Byron, and Duff, who governed the island from $\mathrm{I} 764$ to $\mathrm{I} 775$, correctly inferred that their jurisdiction-except between Frenchmen and Frenchmen-was sole and exclusive, took French vessels which traded or shipped furs along the Treaty coast before the Vice-Admiralty Court at St. John's, sent French trespassers back to France, and ordered their subordinates to expel any French armed force which they might encounter. The French authorities disputed this interpretation, and raised an additional and still more unfounded claim with regard to the boundary of their fishing easement on the west coast. In sustaining this claim French arguments derived valuable assistance from English ignorance.

Captain Taverner had vainly petitioned in 1726 for which were a Commission to survey the north and west, even as he had already surveyed most of the south coast of Newfoundland; spite of so, in 1729 , he sailed on his own account up the east coast as Taverner, far as Belle Isle Strait (Cape De Grat), where the captain of a Breton fishing-fleet turned him back, saying ${ }^{2}$ ' that I was a terraw (sic) to all the coast, that they had never seen an

1 Instructions to Palliser, and legal opinions March 21, 1764 , and May 6, 1765, in John Reeves' History of the Government of Newfoundland, I 793, pp. I 20, 130.

2 See Taverner's Petition and Reports, March 28, 1726, ? 8, 1729, Feb. 5, I 734 . 
Englishman there before, and perhaps in two or three years I might come and take all their ships from there in case of a war'. Five years later he made his trip along the south coast to Cape Ray, finding French fishermen from the Basque ports of St. Jean de Luz, and Bayonne, Breton traders, Micmac hunters from Ingonish, and the detached French colony at Port-aux-Basques to which reference has been made. He wished now to complete the circuit of the island by sailing up or down the west coast. No Englishmen had visited it since Wyet visited St. George Bay in I594. ${ }^{1}$ Many Basque and a few Breton ships visited the northern parts of this coast from Belle Isle Strait during the seventeenth century, and at the close of the century Spaniards still fished at Port-au-Choix. Otherwise the west of the island was ' waste and never yet possessed.' 2 After the Treaty of Utrecht the north-west coast was visited every winter by 'the French Governor of Grand Bay in Nova Francia'-clearly M. de Courtemanche of Fort Ponchartrain in Bradore Bay-with seventy or eighty Montagnais Indians from Labrador. So at least Taverner was told, and he longed to explore these lonely regions; but his longing was unfulfilled, nor was the truth of these rumours ever tested. It is clear, however, that the culture (if any) of the west coast differed from the culture of the south and east coasts; and it was dotted with French or Basque names of inaccurately marked Bays, such as St. John (or Port-au-Choix) Bay, Ingornachoix Bay, Bonne (or Belle) Bay, Bay of (Three) Islands, Port-à-Port Bay, and of obscure and shifty Capes, of which the most obscure and shifty was assuredly Point Rich.

and as to During fifty years Point Rich and Cape Bonavista had Point Rich, been defined as the two termini of French fishing-rights, and which was men spoke of Point Rich and Cape Bonavista with the same an un. known glib and confident familiarity as they spoke of Flamborough place in spite of and Holyhead. Nevertheless few maps noted the critical Cook: 
Point Rich, and of those that did some correctly placed it north of Ingornachoix Bay, ${ }^{1}$ others at the Bay of Islands, ${ }^{2}$ or even at Cape Ray, ${ }^{3}$ which is 2 I o sea-miles south of where Point Rich ought to be. The charts of the whole west coast north of St. George Bay, except, oddly enough, the interior of the Bay of Islands, were out of drawing and mutually inconsistent until $\times$ 768, and few Frenchmen and no Englishmen knew anything whatever about it. Accordingly Captain Cook, who had served in Newfoundland under Lord Graves in 1762 , was sent to survey this coast. Apparently the coast was then deserted, so that he threw no light on its inhabitants or visitors; but his masterly survey amongst other things presented Newfoundland in its correct shape for the first time ( 1768 ), delineated Port Saunders in Ingornachoix Bay, traced the River Humber from its mouth in the Bay of Islands to the neighbouring Deer Lake, and fixed the latitude of Point Rich; but that unruly Point immediately afterwards broke loose from its moorings, and the outbreak of war with France ( 1778$)$ surprised diplomatists in the midst of their unfinished arguments as to its locality.

Exclusive jurisdiction, exclusive rights of settlement were therefore questioned; and geographical fixed points wandered like of Vereaty will-of-the-wisps. The recognition of equal rights for French sailles suband British on Bonavista and Exploits Bays, which had been exclusively occupied by the British for three-quarters of Jophes and a century, was monstrous. It was plainly the duty of diplo- Kay for matists to sweep away these uncertainties and anachronisms, vista and Accordingly the Treaty of Versailles ( 1783 ) deleted Cape Point Bonavista and Point Rich from the Treaties of Paris and 1783 , Utrecht and substituted Cape St. John,-beyond which there

${ }^{1}$ See e. g. British Museum, Royal Library, Maps, K. II 9 (98), Moll's Map (1700?); British Museum 71090 (2), Gibson's New and Correct Map (I762); and 71095 (I) Kitchen's New Map (I760?), \&c.

${ }^{2}$ Jean Denys' Map; comp. J. Friend's chart (1713) in British Museum, S. 9 (8) 36.

3 British Museum, Royal Library, Maps, K. II 8 (38), Moll's Map (1715); British Museum MSS. 22875, fol. 100 (1752 ?). 
was only one English settlement on the east coast (at Sop Arm),- and Cape Ray,- - beyond which there was only one English settlement on the west coast (at St. George Bay) - as the new frontiers of the shores and seas on and in which equal fishing rights were conceded. It was as though Fife's Ness had been substituted for Flamborough, and Land's End for Holyhead. The Treaty coast gained, and the purely English coast lost in size. Frenchmen were excluded from the estuary of the Exploits River, which is the greatest river in Newfoundland; Englishmen shared with Frenchmen the estuary of the Humber, which is the next greatest river in Newfoundland; and idle disputes about names were laid to rest.

and the Declaration of Versailles vetoed English settlements English king would remove English settlers and would there. 1783. prevent English fishermen from competing with French fishermen on the Treaty shore. The policy of keeping English settlers out of the Anglo-French preserves was of doubtful legality, but it had been adopted to some extent in I 764 , and was only invested with the sacro-sanctity of an International Declaration for the first time in 1783 . The policy of warning English fishermen off the Anglo-French preserves, where Frenchmen fished, was novel and contrary to the Act of 1699 ; accordirigly a special Act was passed in I 788, reciting the Treaty and Declaration of Versailles as though they had equal validity, and authorizing the Governor to remove not only permanent buildings but fishing-stages, cook-rooms, boats, and ships from the shore between Cape St. John and what the Act, with unconscious humour, denominated Cape Rage, in order to give effect to the spirit as well as the letter of the Declaration. ${ }^{1}$

128 George III cap. 35. 
The Treaty of Utrecht, as amended by the Treaties of This Paris and Versailles and by the Declaration of Versailles, $\begin{gathered}\text { Treaty con- } \\ \text { cluded the }\end{gathered}$ regulated the reciprocal rights of England and France down French to 1904 ; and diplomatic history as between Newfoundland $\begin{gathered}\text { Series of } \\ \text { Treaty }\end{gathered}$ and France came to an end in 1783 , for subsequent wars rights, only took away, what treaties subsequent to the wars restored to France. Newfoundland was swathed in treaties, and the last of its Anglo-French swaddling clothes were donned in I 783 , which was the year in which the first of its AngloAmerican entanglements began.

The Treaty of 1783 conferred on inhabitants of the and conUnited States rights, which the Anglo-American war (1 81 2- ferred fish14) abrogated, and the Anglo-American Convention (1818) for the renewed and enumerated as :--(I) a concurrent right ' to take first time fish of every kind' ( $a$ ) on the south ' coast ' between Cape Ray United. and the Ramea Islands, $(b)$ on the west ' coast' between Cape ' Ray and Quirpon Island, $(c)$ on the 'shores ' of the Magdalen langruage. Islands, $(d)$ on the 'coasts, bays, harbours, and creeks' of Labrador from Mount Joli, through Belle Isle Strait, northward 'indefinitely along the coast', subject to the Hudson Bay Company's rights; and (2) a right to dry and cure fish 'in any of the unsettled bays, harbours, and creeks' $(a)$ of the said south coasts, and $(b)$ of the coast of Labrador. The Convention added that after settlement the settlers might allow 'drying and curing', but did not expressly confer any drying or curing rights in the Magdalens or on the west coast; and the reader may wonder at, but no one has yet solved the subtle distinction between ' shores' and 'coasts', and 'coasts' plus or minus ' bays, harbours, and creeks', and ' bays, harbours, and creeks ' plus or minus ' coasts'. Besides, are whales, walruses and lobsters fish? Are cod really caught on the shore? Are the United States, is Newfoundland, or are the fish to decide, when and how the fish are or are not to be caught? And does not the Treaty say that in some places what may be killed may not be cured, and what 


\section{HISTORICAL GEOGRAPHY OF NEWFOUNDLAND}

may be cured may not be killed? If not, which presupposes which? or are they identical?

There were The military incidents of this half-period shook the conno impor. tant mili. tary incidents, except the mutiny of 1800 , tinents of America and Europe to their foundations, but were scarcely felt in Newfoundland, and the immunity of Newfoundland was due partly to its own preparations for defence, and partly to the absence of an effective French base. St. John's and Placentia were garrisoned even in peace time; in the first war Governor Edwards (1 779) commanded nine men-of-war, 450 regulars, and 300-400 paid local volunteers; and in the second war a regiment of Royal Newfoundland Fencibles was raised in Newfoundland and served there (1794-1800), but it contained many Irishmen, some forty or fifty of whom took the oaths of United Irishmen, and formed the nucleus of a conspiracy in which 200-400 citizens of St. John's were implicated. Five of the mutineers were executed, the conspiracy evaporated, and the regiment was disbanded, and was succeeded by the Newfoundland Light Infantry, one thousand strong, and they by the Royal NewAdmiral foundland Rangers until the close of the war. The services Richery's of the local troops were required in 1796, when Admiral
attack, Richery appeared off St. John's with a powerful French fleet. Governor Wallace immediately proclaimed martial law, enrolled every male in the district, and formed a camp of 2000-3000 men on Signal Hill. The French Admiral retired, attacked and burned Bay Bulls, did some damage to English shipping off Labrador in Belle Isle Strait; and then and the went home. St. Pierre and Miquelon never served like taking of Plerre. Placentia as a base for operations against St. John's ; but, conversely, St. Pierre and Miquelon were four times attacked from St. John's in $1778, \mathbf{1} 793, \mathbf{1} 803$, and 1815 . On the first and second occasion all the settlers in these islands were sent back to France; and France sent them all back in 1783 and 18 i6. The poor islanders were beaten to and fro like shuttlecocks by battledores. The islands, which were scarcely 
inhabited in the early eighteenth century, had suddenly become populous after the conquest of Cape Breton Island, but did not grow more populous until the second quarter of the nineteenth century. ${ }^{1}$ They never had any strategic significance. During all these wars privateers lost and won much shipping and more money; and Admiral Richery's exploits must be classed with those of privateers, although his designs were the designs of Dumouriez, Pichegru, and the pre-Napoleonic Napoleons.

The possibility of raising regiments in Newfoundland was Residents a sign that times had changed since the days when Newfound- ${ }^{\text {nowe out- }}$ numbered land was looked on as nothing but 'a great English ship visitors, moored near the Banks during the fishing-season for the convenience of the English fishermen'.2 Between I 764 and I 774 residents for the first time continuously outnumbered visitors. During these years the winter residents, including male hangers-on as well as settlers, averaged $12,34^{\circ}$; and visitors, including 'passengers' as well as ships' crews, averaged 11,876 ; or, excluding male hangers-on from the one side and passengers from the other side, residents averaged 5,660 and visitors $5,435^{3}$ Figures no longer yielded an uncertain sound. The Rubicon was only just crossed, but was indisputably and irrevocably crossed. Thenceforth the living-rooms were larger than the corridors, and political arithmetic pointed at the permanent occupants as the men of destiny. In I 764 the new tilt of the balance struck the law officers of the Crown, who wrote that it was 'disgraceful to suffer' the Act of $\mathrm{I} 699$ 'to remain in the Statute Book' as circumstances had so much changed. ${ }^{4}$ The disproportion

${ }^{1}$ c. 20 settlers with families and servants, say 200 persons, I715; 1,600 persons, I765; 1,932 (Anspach), I 778; I 502, I793; 2130,1848 .

${ }^{2}$ William Knox, in Second Report of House of Commons' Committee on Newfoundland Trade, 1793, printed in Parliamentary Papers, vol. xlii of the General Collection, No. 107, p. 16; reprinted in Reports from Committees of the House of Commons, 1893 , vol. $x$, p. 413 .

3 Second Report on Nerwfoundland, I793, App. 6, H.

$4 \mathrm{~J}$. Reeves, History of the Government of Nerufoundland, 1793, p. 123 . 
increased; and the 12,000 inhabitants of $1764-74$ swelled to 17,000 in $1792,20,000$ in 1804 , and 52,000 in 1822 , without any corresponding increase on the part of those who appeared every spring and faded away every autumn, like leaves or flowers.

and came from more or from larger home ports,

New sources of supply were tapped and home ports took more part, or more home ports took part in the life of the colony. Not but what there were drawbacks. Reeves wrote in I 793 that 'Bideford and Barnstaple were once great towns and have long ceased to employ any ship' in this trade ${ }^{1}$; and it was the same with Gweek, St. Loo, Mevagissey, Fowey, and Topsham, which used to contribute their tiny quota to the fishing-fleet, and now contributed no more. Reeves suggests that Dartmouth rose out of the ruins of the smaller ports; adding that whether this was so or not, 'Dartmouth and Poole were now the two great towns in this trade'. 1 The Poole merchants, who had long since led the van, now occupied Twillingate in force, and had been preceded or accompanied by salmon-fishers as well as sea-fishers in their northern migrations. Jerseymen and Guernseymen were busier than ever in parts which had been French, not only fishing, but settling, trading, and smuggling French brandy and cordage. ${ }^{2}$ The lesser lights went out, but the larger lights burned more brightly and steadily; large progressive towns took the place of small villages, and Newfoundland was ' thrown much more open than it used to be, ... instead of being confined to the West country merchants and to those e.g. Liver- of Poole and some few other towns'. ${ }^{1}$ London and Liverpool, Cork, Glasgow, pool now entered the lists; and in $\mathrm{I}_{7} 6_{3}$ Cork, Waterford, Belfast, and Glasgow, as well as the south-western towns of England, advised the Privy Council on the affairs of Newfoundland. The places of origin were no longer 'solidaire'

$1 \mathrm{~J}$. Reeves, Evidence, pp. 42, 83, 84 .

2 Captain Griffith Williams, Account of the Island of Newfoundland, 1765 . 
or likely to impart a single political hue to the place of destination; not that that mattered much, for in the eighteenth century economics were more to the fore than politics; but the widening of the base, although it brought no new political, brought many new economic forces into play. The merchants of Poole, Jersey, and Guernsey resided on both sides of the Poole, Atlantic, thereby promoting instead of opposing settlement, Jersey, ' and it is in the memory of several persons when the trade of St. John's was in the hands of five or six merchants ; . . . at present the number of persons who can furnish supplies is so increased that all monopoly is broken and a very active competition is come in its place'.' In and after $1775^{2}$ the and fetters were struck off Ireland, so far as colonial trade was Ireland, concerned; the interest of the westernmost island of Europe in the easternmost island of America was enhanced, and the Irish influx, which produced in $\mathbf{1 7 5 4}$ a savage murder by citizens and soldiers, produced in $\mathbf{r} 800$ a mutiny which might easily have ripened into a rebellion. Intercolonial trade became more free. Canada instead of New England fed Newfoundland. Newfoundland artificers helped to defend Quebec in 1776 ; the Royal Newfoundland regiment fought and its for Canada in the Canadian war $(1812-14)^{3}$; and Celtic Irish Newfoundlanders began to emigrate to Nova Scotia and Prince Edward Island, where Celtic Irishmen were hitherto unknown. In 1788 some merchants of Bermuda sent ships with black slaves to the Great Banks, where they fished with success, returning to Newfoundland to cure what they caught. Englishmen as well as Newfoundlanders were alarmed at their skill, prophesied that black would drive out white labour, and procured the enactment of a law, which confined the right to dry and cure fish in Newfoundland to the British who

1 J. Reeves, Evidence, p. 84 .

2 Palliser's Act, 15 George III, c. 3 I, s. 5 .

3 C. P. Lucas, History of Canada, I763-1812, p. I 4 ; The Canadian War of 1812 , passim. 
hailed from Europe and to Newfoundlanders. ${ }^{1}$ Jealousy of cheap labour was expressed, and a note was struck which has been sounded again and again by the new-born English colonies of the nineteenth century, but which was seldom and Eng- heard in the older group of lost colonies. The black man lish felons being excluded). did not reappear in Newfoundland. The felon reappeared once. Shortly before the Declaration of Independence felons were being transported to the American continent by a single contractor at the rate of 473 per annum, and were being sold to the American planters for $£ 8$ or $£_{10}$ a head. When that market was closed, one cargo of Irish convicts was dumped down in St. John's, and, according to Richard Routh, who was an officer of the custom-house, it was only the vigilance of the custom-house officers which saved the town from fire and rapine. ${ }^{2}$ With these exceptions, Newfoundland remained free both from the black and white plague which tainted so New settle- many of our early colonies in their early days.

inents were made by

Newfoundland began to be looked on as something more Micmacs on than a golden casket full of mocking emptiness, and Captain the South coast,

Cook traced the Humber inland while Major G. Williams explored the interior of Avalon Peninsula (I 768), which soon became known from end to end. ${ }^{3}$ Coasts were inhabited which had never been inhabited before. Micmac Indians from - the Continent, who used to visit the Magdalen Islands ( 1597$){ }^{4}$ St. Mary Bay (I662), ${ }^{5}$ Cape Ray (I 718,1734$),{ }^{6}$ and the south coast between the neighbourhood of Cape Ray and the Bay D'Espoir $(1763),{ }^{7}$ now began to settle in the Bay

129 George III, c. 53 ; comp. Palliser's Act, s. 4 .

2 Third Report of the House of Commons' Committee on Nerufoundland, I793, p. 44.

3 See e.g. Report of House of Commons' Committee on Nervfoundland, 1817 , evidence of George Kemp, junior.

4 Ante, p. 29.

5 Ante, p. 79.

- Sic Captain Taverner, ante, p. 132.

7 Sic Captain Thompson cited by Anspach, op. cit., p. 182 ; and by Richard Brown, IIistory of Cape Breton Island, p. $35^{6}$. 
D'Espoir (1765 or before 1822 ), ${ }^{1}$ White Bear Bay, ${ }^{2}$ and St. George Bay $(1783))^{3}$ They pierced through the wooded belt which fringes the sea-board, and hunted somewhere on the bare mossy or rocky barrens beyond-no one knew where, when, or how; and rumours were bruited abroad in the second quarter of the nineteenth century that Beothics as well as deer were their quarry. ${ }^{4}$ At St. George Bay the Micmacs by Englishassociated with English and Jersey settlers, who were there already ( 1783$)$, and remained there in spite of the Declaration of Versailles, and who in 1813 were one hundred in number, with a chief constable, and with a versatile Irishman who used to dress as an Indian and to officiate at weddings and funerals, as though he were the self-ordained priest of some new religion. One or two English families are said to have inhabited the mouth of the Humber from 1780 onwards, and one English family is said to have inhabited Little Harbour at the entrance to Bonne Bay from 1809 onwards. ${ }^{6}$

In 1762 there were salmon-catchers and settlers at the mouth of the Exploits River, and some Beothics, while on their annual pilgrimage to the seashore, met the settlers, embraced and slew them. In 1768 Lieutenant John Cartwright, R.N., accompanied by his brother Captain George Cartwright, by a settler, and by some seamen, undertook the most important upland journey which had hitherto been undermen and Jerseymen at St. George Bay, taken, and ascended the Exploits River as far as Red Indian Lake, which they were the first white men to see. ${ }^{6}$ The river

1 Sic Captain T. Cole, cited by Captain Griffith Williams, op. cit., p. 34, and comp. Pedley, History of Newfoundland, pp. I 2 1-2, App. VII, p. $5^{I} 3$. Qu. at Conne Harbour?

${ }_{2}$ ' Little Barrisway.'

${ }^{3}$ Lieutenant Edward Chappell, Voyage of H.M.S. Rosamund to Nerefoundland and Labrador, 1818, p. 76.

4 Post, pp. 16, 164 .

5 Joseph Beete Jukes, Excursions in Nerufoundland, 1839-40, vol. i, p. 115 ; Church in the Colonies, No. 25 (I849); E. Chappell, Voyage of H.M.S. Rosamund to Nevefoundland and Labrador, 1818, p. I95, only mentions summer settlements.

- Frances D. Cartwright, Life and Correspondence of Major Cart. zuright, 1826, vol. i, pp. $3^{2-9}$; vol, ii, pp. 307 et seq. 
was guarded for some thirty miles by fences for impounding deer, while on their way from their summer haunts in the wild woody north to their winter haunts on the wilder woodless barrens in the middle south. The pounds belonged to the Beothics, who were themselves migratory, living partly by the inland lake on venison, partly by the shore on birds and eggs, and partly by the river-banks on venison. ${ }^{1} \mathrm{~A}$ few years later two salmon fishers on the Exploits repeated this expedition, in order to destroy these salmon-like migrants in their uppermost haunts, reached their winter villages by the lake, shot or drove off the inhabitants, and burnt the houses, with the approval of their fellow-countrymen. ${ }^{2}$ In September, r 803 , a Beothic woman was brought by an Englishman to the

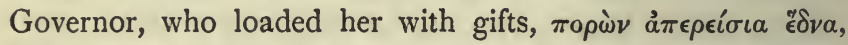
and sent her back, vainly expecting to make the rich-returned lady an ambassadress of peace. ${ }^{3}$ In 18 ro Captain Buchan, R.N., left two marines for a few hours with the Beothics of Exploits Bay as pledges of peace; and the marines were duly welcomed and decapitated. Haie and Whitbourne observed long ago that the redskins had fled northward and westward before the white men. -Guy parleyed with them in Trinity Bay, but they too were scared and fled next summer. Then for a century and a half history was silent or gave dark hints as to the doings and sufferings of this shy persecuting but persecuted people. And now in these latter days, when northern extension brought Englishmen near their last lairs, the Beothics flitted fitfully once more across the tragic stage, were still the same treacherous fugitive phantoms, but fewer and more implacable than of yore, were last seen in their wild state in 1823 , and then vanished for ever, even as the white bears and great auks, which early travellers saw, have vanished

${ }^{1}$ C. Pedley, History of Nerufoundland, 1863, p. 480.

2 First Report of the House of Commons on Nervfoundland, r793, p. 38, Major Cartwright's evidence.

${ }_{3}$ Rev. L. A. Anspach, History of Newefoundland, 1819, p. 245 ; C. Pedley, op. cit., p. 226, 
from Newfoundland, and for the same reason as the Tasmanians vanished from Tasmania. Continental aborigines, white savages, and consumption, which is a white man's malady, accelerated their doom; but how could they fish where white men hauled the seine? or hunt without dogs or guns, where white men and Micmacs hunted with dogs and guns? They could not dig, and to beg they were ashamed. There was nothing for them to do but die. In $1827 \mathrm{~W}$. E. Cormack, fired with the enthusiasm of humanity, founded an Institute at St. John's for civilizing the Beothics; but in I 827 there was only one Beothic in the world, and she was a poor captive, who was dying of consumption in the hospital at St. John's; and was it really worth while to found an Institute in order to civilize her? Moreover, she died in 1829 , and with her died the last of the Beothics. But the Institute flourished more and more.

Labrador, (east of River St. John), the Magdalens, and Labrador Anticosti were united with Newfoundland from 1763 tor 774 , began to bo and Labrador was the scene of more successful intercourse, not only with the Mountaineer Indians-who, like the Beothics, were Algonquins and lived inland,--but with the Eskimos, who caught whales and seals upon the coasts. Said Lord Mansfield ( 1780 ), ' Since the Treaty of Paris a new trade has been opened to Labrador.' 1

Governor Palliser ( $1764-8$ ) built Fort Pitt in Pitt Harbour by Palli(Château Bay) and garrisoned it with marines, both summer ser's garriand winter, in order that the prophecy of Parkhurst (1578) English might be fulfilled, that if we peopled and fortified Château Bay frms, ${ }_{\text {Jerseymen, }}$ we should be 'lords of the fishing in small time'. Immediately and Major afterwards Messrs. Noble and Pinson, of Dartmouth, opened $\begin{gathered}\text { Cart- } \\ \text { zuright }\end{gathered}$ establishments at Temple Bay (Château Bay), and L'Anse-à- and to be Loup; while Nicholas Darby, of Bristol, went to Charles visited from NewHarbour and Seal Island, a few miles north-west of Cape foundland; Charles (I 767 ). In 1770 Captain George Cartwright suc-

${ }^{1}$ Noble $v$. Kennaway, Douglas's Reports, vol. ii, p. $5^{12 .}$ 
ceeded N. Darby as representative of another Bristol firm, and lived in Labrador, either in Charles Harbour (1770-5) or one hundred miles further north in Sandwich Bay (I77486), off and on, with an odd retinue of maidservants, Irish labourers, and English convicts, for sixteen years. American privateers plundered him in 1778 ; and before he left, Messrs. Noble and Pinson's fishermen and trappers pursued and harried him, on every river-bank; two Englishmen passed him and wintered still further north at Hamilton Inlet (1777-8); French Canadians wintered by his side in Sandwich Bay while on their way to settle in Hamilton Inlet ( $1785^{-6)}$; and he saw Messrs. Slade of Poole sealing along the shores of Labrador, 1773 et seq., and other Poole-men, who, having been driven by the Declaration of Versailles $\left(x_{7} 8_{3}\right)$ from the fisheries and factories, which they had set up at Sop Arm, on White Bay ( 1762 ), settled on the north shore of Belle Isle Strait. ${ }^{1}$ Dartmouth, Poole, and Canada began to press Bristol with their competition.

It was about the same time that Jerseymen set up large fishing establishments with resident superintendents and clerks at Blanc Sablon and its neighbourhood, on the borders of what is now Quebec Province. Establishments of the Channel Islanders now ran like a ring around the whole Gulf of St. Lawrence, from Cape Breton Island and Prince Edward Island to Bay Châleurs and Gaspé, and back again along the north shore of the Gulf to Belle Isle, serving as rallyingpoints to the dispossessed Acadians, and as mediating links between the old-English and new-French subjects of the British Crown. After the Treaty of Paris Jerseymen and Guernseymen repeated on a larger scale the political services which they rendered at Placentia after the Treaty of Utrecht. All or almost all these new settlers in Labrador were either Newfoundlanders, or came from the same stock as those who had peopled Newfoundland; the settlements were for fishing,

1 George Cartwright, Journal, vol. iii, p. 199. 
hunting, and trading purposes, and whales, seals, otters, bears, beavers, salmon, and cod were caught or bought by barter from the natives. Meanwhile, other transitory fishermen used to come from Conception Bay during the summer and fish off the coasts of Quirpon, Griguet, and St. Anthony in the north-easternmost parts of Newfoundland during the second Anglo-French war, and now that the war was over and the north side of the Strait was occupied, they too, like the Poolemen, transferred their energies to Labrador.

Except for the natives, the experiences both of residents and relaand visitors in Labrador were replicas of former experiences in Newfoundland. There had been hardly any barter between Eskinios. white men and Beothics, and in Labrador the ways of the English traders were partly smoothed by Frenchmen, who had been in those parts since Cartier's time, had foregathered at or near Bradore Bay in the seventeenth century, had had some sort of fort there in the eighteenth century, and had made friends with the Mountaineer Indians. In making friends with the Indians, they made foes of the Eskimos, who in the times of Le Clercq and $\mathrm{La}$ Hontan still frequented the north coasts of the Gulf of St. Lawrence, as far west as the Islands of Mingan, opposite Anticosti. ${ }^{1}$ The Indians of Labrador dwelt inland, but used to visit French ships, from which they received guns and ammunition in exchange for furs and skins. There had been hereditary war between the Indians and Eskimos from time immemorial, and fire-arms turned the scale in favour of the Indians, who gradually extirpated the Eskimos of the Gulf. While this war was in progress, the Eskimos frequently crossed Belle Isle Strait and attacked the Breton fishermen in the peninsula of Petit Nord, ${ }^{1}$ and on one occasion slew some straggling Frenchmen in the neighbourhood of Petit Maître (Croc), clothed themselves in the clothing of the slain, and thus secured twenty-one more

1 Chrétien Le Clercq, Nouvelle Relation de la Gaspésie, I69I, pp. 453, 46I ; La Hontan, op. cit., pp. 309, 334; compare F. D. Cartwright, Life of Major Cartwright, vol. ii, p. 316.

voL. V. PT. IV 


\section{I46 HISTORICAL GEOGRAPHY OF NEWFOUNDLAND}

victims. $^{1}$ The last of the Eskimos of Belle Isle Strait continued after $176_{3}$ to cross over to Newfoundland, where they were met at Quirpon Island ( 1 764) and were at last reconciled to Europeans by Moravian missionaries, who settled by their side, trading for them and converting them, first in Château Bay ( 1765 ), then far north of Cartwright's furthest in Nain ( $177 \mathrm{I}$ ), ${ }^{2}$ Okkak $(1775),{ }^{3}$ and Hopedale $\left(I_{782}\right) .{ }^{4}$ Frenchmen won the hearts of the Indians; Moravians won the hearts of the Eskimos; tactful Englishmen, who came into Labrador after 1763, amongst whom Captain George Cartwright and his partner Lieutenant Francis Lucas were pre-eminent, addressed themselves with equal success both to the Indians and Eskimos, and the eternal feuds of savages began to fade away in the dawn of the white man's civilization. Governor Palliser ( $1764-8$ ), who encouraged Cartwright, Lucas, and the Moravians, and made treaties with the Mountaineers and Eskimos at Fort Pitt in Château Bay, added the coping-stone to the work of pacification. The only hindrance to these pleasant relations arose from certain New Englanders, who followed in the wake of the traders, made mischief with the natives, and in the Nineties became great whalers and walrusers, concentrating their main destructive efforts on the whales of Fortune Bay in the south of Newfoundland, and on the walruses of the neighbouring Magdalen Islands, where however there were no aborigines. Nor were the fishingadmirals a help either in these or in other matters.

Then - By the proclamation of October 7, I763, Labrador, Labrador Anticosti, and the Magdalen Islands had been annexed to the differently, colony of Newfoundland; but opposition to the fishingand

Canada regained what Newfoundland lost. admirals, and to the system which they represented, was raised by those who fished, traded, or settled in Labrador and the Magdalens under the protection of Canadian law, and caused Labrador, and with Labrador the Magdalen Islands

1 Colonial Papers, I574-1660, vol. $x$, No. $3^{8}$.
${ }^{2} 56^{\circ} 33^{\prime}$ N. lat.
$357^{\circ} 34^{\prime}$ N. lat.
$455^{\circ} 3^{\prime}$ N. lat. 
and Anticosti, to be re-annexed to Canada (1 774); Labrador and Anticosti being re-restored to Newfoundland by the Act which finally abolished the jurisdiction of the fishing-admirals $\left(1809^{1}\right)$. The Magdalens, which had begun to attract French Acadian fishermen before 1774 , remained Canadian. Further, for the purposes of these Acts the western boundary of Labrador was St. John's River (opposite Anticosti), but French Canadian or Acadian fishermen were now frequenting the coasts of Labrador as far as Bradore Bay, which is nearly three hundred miles east of this boundary; moreover, Anticosti, which was uninhabited, had wrecked many a ship while on its way to Quebec; accordingly a later Act ${ }^{2}$ re-rerestored Anticosti to Canada, and defined Labrador as east of a line drawn due north from Blanc Sablon to latitude $5^{2}$, but the northern prolongation of this line to Hudson Strait was not defined either by this later Act, or by the letters patent which put the Atlantic coasts of Labrador under Newfoundland ${ }^{3}$, or by any other Act or letters patent, and the Privy Council are still considering what line shall be drawn.

Progress was intensive as well as extensive, and Englishmen Bounties became great sealers; but although Palliser's Act (r 775) and wereoffered for whala similar Act passed in $\mathbf{1} 786$ offered bounties to British ing, bankwhalers who sailed thither from a British port in Europe, these fishing, and bounties were ineffectual, and Englishmen only became out apprenwhalers in North-east America during the ensuing period. On the other hand, bounties offered between I 775 and 1802 to British fishermen on the Banks, who sailed thither from a British port in Europe, were superfluous and only added spurs to a galloping industry. Bank-fishers were put into a separate class by the statisticians of 1769 for the first time, and in that year out of 47 I British ships, which sailed to Newfoundland, 222 fished on the Banks. It was thought, however, by adherents of the old school that 'bankers' did not carry their

\footnotetext{
149 Geo. III, c. 27 , s. I4.

${ }^{2} 6$ Geo. IV, c. 59 , s. 9 .

3 March 28, 1876.
} tices; 
fair share of apprentices; accordingly the bounties were only bestowed on ships which carried fifteen (I 775), twelve (I 786), or, if profits were paid in lieu of wages, seven men ( 1786$)$. Formerly Parliament threatened those who did not, now it petted and coddled those who did carry out apprentices. The old order was dying, and its life was being prolonged by bribes and prizes. The Act of 1699 still cumbered the Statute-book; but it was already in rags and tatters, and no one heeded what it mumbled. It proposed to make Newfoundland a training-ground for sailors for the Royal Navy; yet during the Napoleonic wars officer after officer of the Royal Navy complained that nowhere in the wide world were sailors readier to desert or harder to replace. ${ }^{1}$ Its last mask was off ; and the hollowness of its pretence to this particular

and security was taken for preventing. emigration to Nere England. virtue was exposed. It attempted also to prevent sailors and craftsmen from leaking through Newfoundland to other colonies, but now the merchants of Placentia, who complained that English sailors were leaking through Placentia into Nova Scotia, were rebuked. Though discredited and repudiated, a last effort was made to re-enforce or adapt one of its provisions, in order to prevent fishermen from taking out 'passengers' to New England. Re-emigration to New England had been forbidden for a century or more by every means which charters, laws, or executive ingenuity could devise; until Lord Vere Beauclerk at last wrote 'whether they (the New Englanders) are esteemed aliens or strangers by the law I could not really determine'.2 Now that these doubts were dispelled, the policy justified itself for the first time, and was pursued with conviction as well as persistency. In the first place each employer was to deduct from the wages of his passenger-employees forty shillings a-piece (or less) for their return fares and to arrange for their return. But what if the passengers worked for profits and not for wages? or sojourned,

1 C. Pedley, History of Newfoundland, 1863, pp. 285-6.

2 Dispatch, Sept. 26, I 730. 
as most did, for two summers and a winter and served several masters in succession? or refused to return home? or disappeared? or died? What, too, if forty shillings were deducted and the home fare was, as it sometimes was, twenty shillings? The answers to these questions lent a new significance to the old adage Beati possidentes; employers were enriched, and this measure failed to do what it was meant to do almost as signally as Ogle's master-stroke. What success was attained was due to a second measure forbidding unlicensed ships' captains to take passengers to the United States of America. Over this measure the new custom-house and Vice-Admiralty Court watched.

The institution of a custom-house (I764) introduced Permana regular revenue, which, during the eighteenth century, ance was

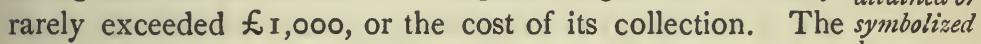
naval officer, who was instituted in $174 \mathrm{I}$, had no regular Custom. $_{\text {. }}$. revenue to depend on, but eked out a precarious livelihood house, by means of casual half-crowns scornfully tossed to him by those sea-captains who graciously allowed him to pry into their cocquets and dockets. From the very first ( 1764$)$ the new custom-house officials collected one-half of their salaries out of customs' dues; and under an Act passed in 1764 smugglers' ships and goods, which in Newfoundland meant New England rum-ships and French West Indian rum, were divided in equal thirds between King, Governor, and prosecutor, the prosecutor's third supplying the other half of the salaries of these officials. Towards the close of the great war customs' dues not only paid the whole cost of the custom-house, but returned a net surplus of $\ell_{1 \mathbf{I}, \infty}$ per annum (18r6). The very institution, which changed continental colonies into alien states, began to invest Newfoundland with the essential attributes of a colony. Progress and permanence in fiscal matters led to other permanent institutions, of which landed property was the symbol and archetype. 
specialland In the first half of the eighteenth century the Act of 1699 , grants, which forbad fishermen to dispossess inhabitants who occupied sites upon the shore continuously since 1685 , 'protection orders' and 'exclusive licences' granted by Governors to salmon-catchers, and 'permissions' by Governors to men like Collins, Keen, and Gill, to 'encroach' upon the free shore-created, or seemed to create, landed tenures in vague language about the meaning of which legal pundits differed; but no one owned so much as a square inch of land or water in Newfoundland, except in one of these imperfect ways or by one of these ambiguous means. In I 775 Palliser's Act superseded the provision of the Act of 1699 , which established I 685 as the date from which time began to run, by making all vacant spaces 'shiprooms', thereby suggesting that non-vacant spaces belonged to their possessors, who could not be ousted from their possession by the vagrant fishermen, who were their only serious rivals. A new right of property was created by implication. Again Dunn, D'Ewes Coke, and perhaps Dr. S. Gardner, were rewarded by the Governor with land-grants for their services in the custom-house; and magistrates like S. Hutchings were similarly rewarded, either by land-grants, or by being allowed to appropriate to their own use half the fees paid to them by publicans for their licences ; while constables were sometimes paid for their services by obtaining licences as publicans on payment of nominal fees. There were no means of remunerating public officials except by privileges, and the greatest of these privileges was a land-grant by the Governor. By far the most important recipients of this species of reward were the military and naval officers who guarded Newfoundland from invasion. 'The principal (inclosures),' said Aaron Graham, 'have been made in consequence of grants to the officers of the respective military corps doing duty in the island ' - which grants were sold to private people by the officers when they left; and he added that 'grants have also been made to officers in the 
different civil departments, and likewise sold by them as private property.' 1 Colonel Pringle and Major Brady left their names to bridges, paths, and the like ; Colonel Skinner, Major Griffith Williams, Colonel Haly, and Captain Edgell, R.N., turned their bayonets into pruning-hooks and initiated farming; in 1773 military roads were begun between the three forts which dominated St. John's, and these were the first roads in Newfoundland; in $\mathbf{1 7 7 5}$ the inhabitants of St. John's petitioned against officers who 'lately enclosed large spots of ground contiguous to their harbour for erecting houses, planting gardens, farms, \&c.', and non-fishers were stigmatized as 'a burden to the land'. As in New. South Wales and almost every colony since 1774 , military men were in the van as pathfinders, roadmakers, agriculturists, and pastoralists ; and the history of our colonies would have to be re-written if the peaceful exploits of warlike pioneers were expunged from their records.

Next to the Army came the Church. The Anglican Churches, Church dates from 1699; the Rev. Laurence Coughlan introduced Wesleyanism in $1_{7} 65$; and land was given from time to time for Anglican and Nonconformist places of worship. Under Rev. James O'Donel, I784, Roman Catholicism became a power in the land; and in 1790 complaints were made by champions of the old order that Irish fishermen were no longer obliged to return to Ireland for absolution as priests were on the spot. In 1796 O'Donel was appointed the first Roman Catholic Bishop for Newfoundland, and, in 1797 , he obtained land on a ninety-nine years' lease from the Governor for a Church or Cathedral. In I 799 the first Grammar School was opened by the Rev. L. A. Anspach, the well-known historian of Newfoundland; so that spiritual everlastings were once for all planted in the earth.

Popular beliefs recognized the validity of titles to land before landed

1 Third Report on Newfondland, 1793, p. 84. See House of yenures, Commons' Reports, I73I-1800, vol. xlii, No. Io7 of General Collection. 
they were legal. Thus Chief Justice Reeves wrote in I 793 that although it was doubtful whether any one in Newfoundland had any title to any land, many houses fetched $£_{3} 00$ or $\AA_{400}$ a year; and at last in I8I I the Home Government made its first plunge into the inevitable, and permitted the sale or letting of land. An English Act was passed which authorized the Governor to grant or let certain vacant 'shipsrooms' at St. John's as private property in the same way as other land in the colony was granted or let; and Governor Duckworth promptly let these vacant spots at rackrents on thirty years' leases, renewable on easy terms in case houses of stone or brick were built thereon. In I813 Governor Keats was instructed to encourage cultivation by granting ' leases of small portions of land to industrious inhabitants at annual quit-rents'. Accordingly he called for men to send in their claims, noted that 75 acres had been enclosed during the preceding nine months, and that over three square miles were cultivated or enclosed, and began to grant leases of four-acre plots, at $2 s$. $6 d$. or 5 s. an acre, renewable 'by way of grant' every thirty years 'for ever'. Quit-rents were still demanded, but leasehold was changed into freehold, and the circulating decimal into the integer. Permanent private property in land was at last a right as well as a fact, and the colony was admittedly terrestrial.

Courts, Permanence and stability were in the air and the Law Courts caught the infection. Before 1792 the Criminal Court was periodically created and destroyed, recreated and redestroyed, like the mythical heroes of Valhalla. There was no Civil Court, although the Governor, whose jurisdiction was grounded on that of the fishing-admirals, heard civil cases by consent, and ordered the sheriff to enforce his decisions. In $\mathbf{1 7} \mathbf{8}$ I an unsuccessful civil litigant brought an action against Governor Edwards in Exeter for having cast him in costs in Newfoundland. The action was compromised, and for the next eight years the Governor closed 
his Court at St. John's to civil causes. A strange state of things ensued. On the one hand fishing-admirals, few of whom could sign their own names, and whose unjust justice was still administered in their own or their favourites' behalf, 'lagged superfluous on the stage' as judges, illustrating the thesis that law in its origin is interested brute force; on the other hand, a new scheme was devised, under which the Governor's Secretary heard both sides and then wrote an opinion, thus illustrating the thesis that law in its nature is disinterested moral suasion. Litigants disliked these embodiments of physical or moral theories, and had recourse to the Vice-Admiralty judges and the magistrates, who did not represent any theory. In 1789 the Governor discovered that his commission authorized him to appoint 'Judges' as well as 'Justices of the Criminal Court', wrongly inferred that judges meant civil judges, and created a Civil Court with three judges. This trio of amateurs resolved discords and produced harmony of a kind until I 79r, when an Act was passed creating a real Civil Court, with cognizance of all civil cases except cases about land, and which began every action, except trifling actions, by the drastic method of arresting the defendant and attaching his goods. In 1792 a Supreme Court of Civil and Criminal Judicature was established, which, amongst other things, superseded the new Civil Court of I79r, and the older Courts of fishing-admirals and Governors, and which had complete civil jurisdiction even over land, made arrest and attachment in civil cases discretionary and alternative, and charged its expenses upon fees and fines. One of the first litigants in the new Court appealed to the Privy Council, and, confusing from long habit the litigant with the judge, wished to arrest both judge and respondent before opening his case ; but he learned to his surprise that judges were no longer regarded as interested parties and that Courts represented ideal right as well as might. John Reeves, the well-known historian of English law, was the first Chief Justice of the new 
Court, and it would seem that legal institutions were at last adequate and complete. But this was not quite the case, and permanence was not yet secured. Reeves only stayed in the island during his long vacations, and was succeeded by ex-surgeons, merchants, and customs officials ; moreover the Acts of 1791 and 1792 were only annual Acts, which were renewed at first annually and afterwards triennially, for the annual and triennial habit of mind clung to the land like one of its own fogs. At last in i 809 a perpetual Act was passed, and the extinction of the Admiral Judges was accomplished; although their shadow survived their substance, and Surrogate Courts, presided over by a junior naval officer, still officiated in the out-ports. The same Act, which consigned the Admiral Judges finally and for ever to the midden-heap, rejoined Newfoundland to Labrador, where magistrates were appointed for the first time in 1813 .

and Although the Governor was the earliest political institution, Governors he was the last institution which acquired permanence.
who became resident,
recaline 1817-18, in Fort Townshend at St. John's, he never spent a whole year
orving to the distresses of $1815-18$. in the colony until $1817-18$. At one time it seemed as though there were to be a permanent Secretary to the evanescent Governors; and A. Graham filled that position under many Governors ( $1779-92)$, and was always 'a much greater man than his master', ${ }^{1}$ but he had no similar successor. At another time it seemed as though the convoy would remain without the Governor who was its captain, and in $1813^{-1} 4$ three ships of war wintered in the island, one at St. John's, one at Placentia, which was then the second largest town, and one at Ferryland, as a defence against the New Englanders, whom bay-ice did not daunt. After $\mathrm{I}_{8} \mathrm{I}_{4}$ a series of great calamities overwhelmed Newfoundland. The colony had been spoilt by war. The ships of the Royal Navy, besides providing constant customers, towed rich prizes into port, and

${ }^{1}$ Sic Jeremiah Coghlan, Oct. $25,1788$. 
drove off rivals in trade. The staple of the colony rose in price. In the eighteenth century cod-fish sold at ros. to I $4 s$. a quintal, and in still earlier times ros. and a quintal were synonymous. In 1814 the quintal brought in 20 s. to $32 s^{1}$ It was almost as if the currency of the colony had undergone twofold appreciation, while the currency elsewhere stood still. Wages trebled, and $£_{7} \circ$ was mentioned as the minimum wage for the season. ${ }^{2}$ Although bread and meat, which came from Canada, were dear, the cup of prosperity overflowed. In I8I5 the cup was empty; the price of cod-fish was once more Ios. to $14 s$. a quintal, bankruptcy was universal, writs of execution fell like leaves in Vallombrosa, and starvation was imminent. Peace, which brought ease, plenty, and blessing elsewhere, brought hardship, penury, and despair here. Nor was peace unattended by misery, even in Europe. The industrial revolution, new machinery, and the end of the long wars flooded European markets with superfluous labourers, some thousands of whom poured into Newfoundland and added to the agony.

Nature by a 'pathetic fallacy' sent the coldest winters on record as a suitable environment. Gangs of hungry wretches extorted or plundered at every store. On February 1 2, I 816, one hundred houses were burnt at St. John's, and the English Government spent $£_{10,000}$ on the relief of the homeless. For the first time in history we read complaints that the population of Newfoundland was 'superfluous and excessive' ; suggestions were made that some 5,000 Newfoundlanders should be shipped off elsewhere, and I, I00 persons or so were actually shipped off to Ireland and Halifax (Nova Scotia). In October I 816 the Governor became 'resident' Governor, and being 'resident' his salary was raised; ${ }^{4}$ and as a sign

1 Comp. post., p. 208.

2 Comp. ante, p. II8.

3 Report of House of Commons' Committee on Nervfoundland, I 8 I 7, No. 436 (in collected ed., vol. vi, p. 465), evidence of G. Garland, J. Preston, \&c.

4 Accounts and Papers, 1824, No. 71 (in collected ed., vol. xvi, p. $4^{\text {I }} 5$ ). 
that he was now a land-mammal he was allowed a horse. In consequence of the change in his position he began to reside in the island both winter and summer, but postponed his first winter sojourn until $1817-18$. In the winter of $1816-17$ crime and incendiarism were rife. Captain Buchan, R.N., of H.M.S. Pike, who was present, alleviated some of the distress and controlled some of the disorder. The winter of $1817-18$ was still colder than that of $1816-17$, and was nicknamed 'the winter of the Rals' or rowdies. It began in November with the burning of three hundred houses in St. John's, probably by an incendiary, and by a frost which lasted until spring. Famine as well as frost and fire was abroad; half the population lived on the other half, and in January, when every harbour was sealed by frost and men's hearts failed them for fear, a Boston ship came crunching through the ice laden with provisions as a present from our late foes. A kinder act was never done. The winter of the Rals was of political as well as sentimental significance, as it was the first winter in which the Governor resided in his government in order to cope with this sea of troubles. The saddest, darkest, and most dangerous winter, which Newfoundland ever experienced, was the first occasion on which the Governor was converted from a fleeting into a permanent institution, and the revolving light became a fixed light.

Thus New- During the seventeenth and eighteenth centuries men used foundland itself became a permanent colony; to argue whether Newfoundland could be called a colony. The English Custom House officials held that it was a colony for their purposes, in spite of what planters said to the contrary: ${ }^{1}$ and the Board of Trade held that it was not a colony because it could not tax or be taxed. ${ }^{2}$ In June $\mathbf{1}_{7} 6_{5}$ a learned legal opinion was given, to the effect that it was a colony for the purposes of Acts enforcing the registration of

1 Calendar of State Papers, Colonial Series, Jan. 12, 1687; Oct. I4, 1698.

2 Ib., May ro, 1698. 
ships. ${ }^{1}$ The Attorney-General, when asked what laws applied to it, replied that every law passed before it was settled applied to it, although it was not mentioned by name; and when asked when it was settled, replied that it was settled afresh every year, and that the Governor took out with him in his inner consciousness on his annual pilgrimage a complete edition of the Statute-book down to date. ${ }^{1}$ As late as 1785 Dr. S. Gardner urged the advantages of colonizing Newfoundland as though no one had ever thought of, much less done such a thing before, ${ }^{2}$ and Dr. W. Carson wrote in much the same strain in $18 \mathrm{r} 3$.

Now that a Governor was permanently established in the the first island the last pretence for insinuating that it was not a colony Governor was torn to shreds. Views might differ as to the date at dying at which the birth act was complete; some might say 1583 , others 1610 , or 1637 , or 1675 , or 1729 , or 1792 ; others again regarded Governor Pickmore's presence during the winter of the Rals as the first conclusive proof that the colony was in being. If so, "The hour was darkest before the dawn, When the pain was sorest the babe was born,' and the historian is tempted to turn once more from politics to personality and sentiment, for Governor Pickmore was also the first Governor who died in the colony. The mid-winter of the Rals killed him. His residence meant death to him and life to the colony, and he died that it might live.

1 Opinion of Fane, A. G., cited in Reeves' History, pp. 1 1 1, 1 1 2, 1 26.

2 British Museum MSS. 15493. 


\section{AuthORITIES}

The State Papers are now no longer accessible; although extracts are accessible in Reeves, Prowse, and other historians. Committees of the House of Commons published three valuable Reports on Newfoundland in 1793 , and another Report in 1817. Reeves and Anspach, and in minor matters Griffith Williams, the Cartwrights, and Chappell write with authority about events in which they took part. In the references to Jukes and the Church in the Colonies may be read recollections by octogenarians of the days of their youth. Statutes of the Realm and Law Reports begin to throw considerable light on the history. The Royal Gazette (Newfoundland) dates from 1807 .

Amongst second-hand authorities, see The Very Reverend M. F. Howley, Ecclesiastical History of Nerwfoundland, 1888. The author is the Roman Catholic Archbishop at St. John's and is a well-known writer on the origins of the history of Newfoundland. 


\section{CHAPTER VIII}

\section{PROGRESS BY IAND DURING THE IAST PERIOD, 1818-1910}

At the beginning of this period Newfoundland, with the Cormack exception of the Peninsula of Avalon, must have seemed to its crossed inhabitants a husk without a kernel. Midnight wrapt once land, 1822, more the mysterious country, on which the Cartwrights had shed a momentary ray of light. The Peninsula of Avalon was already known from end to end, but outside Avalon nothing was known of the inner world, except what could be seen from the sea or from the Lower Exploits River, or what the Cartwrights were rumoured to have seen when they peeped behind the veil. So in 1822 W. E. Cormack, fresh from his new-made colony at New Glasgow, in Prince Edward Island, resolved to take a new prolonged look behind the veil and to make a final exploration of the unknown interior. $\mathrm{He}$ had heard that some of the rivers which flowed south were short and steep, and that the Exploits River, which flowed northeast, was gradual and long; he had seen the charts; and he inferred from these meagre data that an open, high, and dry route would be found along a line to the north of the southerly, and to the south of the north-easterly rivers; so he started with knapsack and rifle from Smith's Sound, near Random Island, in Trinity Bay, and after nine weeks' tramp emerged in St. George Bay, 2 ro miles due west of his starting-point. His was the first long walk in Newfoundland, and it was almost the last. It seemed to prove nothing and to lead to nothing. It was wholly unlike anything that had hitherto occurred in the colony, and men had to think long before they could quite make out what they had learned from it. The only thing that was clear was that they had learned a very barren geographical lesson about a very barren region. 
discovering After piercing through a rising forest fringe for twenty theso-called miles, Cormack reached 'green plains marbled with woods
barrens, and lakes', or yellow-green with reindeer moss, berry-bushes, and thin sedgy grass; and the plains, which were 700 to 800 feet above the sea, were studded with rocky knolls some 700 to 800 feet above the plains. Spruce-beds three feet high with interlacing boughs, marshes and moss-beds three feet deep, over which the caribou ${ }^{1}$ alone amongst the larger mammals could travel, lakes like beads upon many strings, and the daily need for venison, more than trebled the distance which he had to go; and when he was twenty miles from his goal he crossed the granite ridge, some 2,000 feet high, which runs through the whole island from Cape Ray to Belle Isle Strait, and he reached once more a region of steep hills and wooded coastline. Geographically the journey was a success. ${ }^{2}$ but without But in addition to geographical curiosity Cormack was promoting colonization or roads, inspired by two political aims, in both of which he failed. In the first place, being a colonizing enthusiast, he dedicated himself to the service of his fellow-countrymen, and dreamed of some future trunk road, which should lure men inland and forge living links between the lonely dwellers on the west, east, and south coasts, and that was one reason why he chose a high and dry way where bridges might be dispensed with. But the dream proved illusion, although at one time it seemed about to materialize into a telegraph or railway line. Ultimately the telegraph-line, which was built in 1856 from Heart's Content in Trinity Bay to Port-aux-Basques, passed on its winding way from creek-head to creek-head far south of Cormack's trail; and although, when the first big railway scheme was mooted in 1875, Sir Sandford Fleming, the famous Canadian surveyor, selected a northern variant of Cormack's trail as his route, this route was soon discarded, not because of its difficulty, but because of its utter uselessness.

1 American reindeer.

${ }^{2}$ C. Pedley, History of Nerufoundland, pp. 506 et seq.; John MacGregor, British America, 1832, vol. i, p. 260. 
The whole district which Cormack traversed was wilderness in 1822 , was wilderness in 1875 , and seemed likely to be wilderness for ever and ever. Such a railway would have consisted merely of two termini. The route was the route of least resistance, but it was also the route of least attraction. Nor has it even been utilized, like the Pilgrim's Way along the English North Downs, as a bridle-path; for it is supposed that horses would not thrive on the scanty wiry grass or marshplants, and could not cross the forest-belts or marshes. Nor has it been followed by pedestrians. Cormack noted serpentine rocks, with which minerals are often associated in Canada, and gazed on myriads of Caribou, or tracks of Caribou wending their way from their summer woodland retreats towards the open moor in autumn, but geologists like Jukes (1839-40), Murray, and Howley (1864 et seq.), miners like Willis and Guzman, and sportsmen like Dashwood, Selous, and Millais, who have entered those wilds since Cormack's time, have invariably adhered to the better plan, which is the Indian plan, of moving on the wet instead of on the dry, and of following watercourses instead of watersheds. Cormack's geographical discoveries did not open up new country or new roads or even new routes to the white colonists.

In the second place, Cormack was a philanthropist, and and withwished to do something for the Beothics. But he discovered out disto his surprise that, except at King George IV Lake, he was Beothics, never within ten miles of their haunts. He heard for the though he first time of a great war in the long long ago, ${ }^{1}$ in which their Micmac riflemen shot down Beothic archers and their wives frontiers, and children; since which, the Beothics had shunned the haunts of the Micmacs, and had confined themselves more and more to their capital on Red Indian Lake in the middle reaches of the Exploits. Thence they ranged as far as King George IV Lake near the sources of the Exploits, and

1 Jukes, Excursions in Nerefoundland, 1839-40, vol. i, p. I72; vol. ii, pp. I 26-33. 
as far as the mouth of the Exploits, in Notre Dame Bay, and the mouths of lesser streams, which empty themselves into Notre Dame Bay between the Exploits estuary and Hall Bay, and which may in past ages have been subsidiary mouths of the Exploits. They were river-spirits, and the river which they haunted was the Exploits. They touched neither the western nor the southern coast, nor even the feet of Petit Nord Peninsula. They were limited to a single river. Accordingly, in 1828 , Cormack, on renewing his quest, made straight for the dwelling places of the Beothics-pack on back and rifle in hand-searched the whole country between the Exploits estuary and Hall Bay, between Hall Bay and Red Indian Lake, and between Red Indian Lake and the estuary of the Exploits, and searched in vain. The objects of his search eluded his grasp, for they were all dead. He might as well have searched for the ghosts of prehistoric man. There never lived a man who more signally failed to do what he wanted to do by travelling than Cormack. Nevertheless, Cormack's geographical success was not without historical result.

and he dis- While searching for Beothics he found Micmacs and made covered Micmacs, andlearned that their hunting territory was distinct from that of the Beothics, an historical as well as an ethnological discovery. In 1822 his only companion was a Micmac, and to his amazement he met two or three parties of two or three Micmacs, who did not know a time when they or their forefathers did not know the unknown district which he was traversing. There was also a Montagnais Indian living in the western wilds, who had come from Labrador and married a Micmac woman. Cormack's historical discovery-unexpected by him and unsuspected by historians - was that during a century or more, while Englishmen were gazing out seawards with their backs turned to the land, Micmacs with their backs turned towards the sea were hurrying to and fro from end to end of the land that lay south of Petit Nord-sometimes darting at, more often eddying round and avoiding its centre-and unlocking its 
mysteries with their Indian key. The Indian key-if the metaphor may be allowed-is a paddle. They paddled upstream from Cabot Strait or its neighbourhood, hunted all over Cormack's plateau, carried their canoes across short flat ' portages', and paddled downstream into the Gulf of St. Lawrence, or more rarely into the waters of the Atlantic. Thanks to the paddle, their topographical knowledge was a good century a-head of the Englishmen's knowledge, and the paddle was an emblem of power as well as an instrument of knowledge. Except in the Beothic sphere of influence, they, and they only, possessed the land. Their methods were European but European with a difference, and the English ignorance of what they had been doing was due not to any difference between Indian and European methods, but to the abandonment by Englishmen of European methods in colonizing Newfoundland.

All the Micmacs were Roman Catholic Indians from Cape and that Breton Island or Nova Scotia, and, like the white men, came they had spontaneously from overseas, first as visitors, then as settlers; at Conne but they came to hunt, and until they had a firm footing in Bay ana the land they avoided Englishmen.

Indians and Englishmen went different ways although which were indir mepentheir methods were sometimes superficially similar. Like the dencies of white colonists, the Micmacs looked to their old home across $\begin{aligned} & \text { Cape } \\ & \text { Breton }\end{aligned}$ the seas where the chief-chief resided, and resides to this Island, day, in St. Anne's Harbour, Cape Breton Island $;^{1}$ and, like Englishmen in every English island of the world except Newfoundland, they used to go overland from a principal fixed base on one coast to distant goals where less important bases had been established on other coasts. As with their English neighbours, their principal fixed base was and is on the part of the coast nearest to the land of their fathers. In Cormack's time there were two principal Micmac bases-on

1 Sir William MacGregor, Report on the Micmai Indians, I908; Jukes op. cit., vol. i, p. I 76 . 
war bases against the Beo. thics,

Conne River in the east arm of D'Espoir Bay, and at Little Barachois close by White Bear Bay. But they abandoned Little Barachois when Burgeo became populous, and concentrated themselves on Conne River, where they still enjoy their primaeval isolation more or less.

In early times the Micmacs used their settlements on the southern shore as war bases against the Beothics. The date of their earliest coming to these settlements is unknown; but they probably had had long-standing causes of strife against the Beothics, before Frenchmen added fuel to the flames, for Indians have never yet attacked their kith and kin at the mere bidding of white men. Under French instigation, and 'because', we are told, 'the French offered a reward for the head of every Beothic' 1 and the Micmacs went about earning the reward, the Beothics invited some Micmacs to a feast, found scalps in their possession and slew all the guests. Then the Micmacs, who were apparently familiar already with the inmost recesses of the country, undertook a war of revenge, marched down 'Shannoc Brook' to the middle Exploits, and being armed with European weapons almost exterminated their opponents. Cormack's date for these events was $\mathbf{r} 680$ or thereabouts, and as they took place at a time when the French still feared the Beothics, they must have taken place before the Treaty of Utrecht ( 17 I 3 ) and not at the date usually assigned. ${ }^{2}$ We do not know when the Micmacs first came, nor are we sure of the date at which the visitors matured into settlers -except in the case of St. George Bay ( 1783 ), which probably preceded permanent settlement at Conne Bay by a quarter of a century; but long before Cormack's time, and probably long before their great war of revenge, they lived there off and on and looked on the land or on parts of it as their very own.

and starting-points for three inland tours,

The result of this war was that the hunters of the rival

1 Jukes, Excursions in Newfoundland, 1839-40, vol. ii, p. I29; comp. vol. i, p. I73; J. MacGregor, op. cit., vol. i, p. 260, and ante, p. $I_{4} I_{\text {. }}$

2 I 750 or $x 770$ (Peyton). 
nations avoided one another, the Beothics keeping to the centre, and the Micmacs to the south coast and its neighbourhood. The actual coast was only used as a starting-point for those hunting grounds, from which the Beothics were now completely excluded, and of which the white men were as yet completely ignorant. The Micmac route lay north on to the table-land, either by White Bear River ${ }^{1}$ to where its waters interlock with the sources of the Upper Exploits River, or by the east arm of D'Espoir Bay up to a region of lakes, amongst which Crooked Lake and Newfoundland Dog Lake are conspicuous. The latter route was described by Cormack as 'the grand route of the Indians', partly because it led straight into the centre of the country, and partly because it was the middle of three possible routes and the other two routes could be reached from it. Thus the table-land at the head of White Bear River could be reached by a westerly route from Crooked Lake; and an easterly route to the 'Eastern Maelpeg Lake', which is now usually reached from the north end of Fortune Bay, was also within easy reach of Conne Bay and Newfoundland Dog Lake. The grand route was like the trunk of a tree, the first and third routes were like creepers or parasitic plants depending from its two principal boughs, and Conne Bay was at the bottom of the trunk. For that reason, as well as for purposes of segregation, the Micmacs clung, and still cling to Conne River. But the trunk reached far beyond Crooked Lake; and its left and right branches reached far beyond the source of White Bear River and the shores of the Eastern Maelpeg Lake respectively, and led to distant goals situated on the mouths of rivers which belonged to other water-systems. These further routes were threefold and led to the west (or north-west), north, and north-east (or south-east).

In Cormack's time there were several distant goals to (I) zest-

1 Not Little River as Cormack thought. Jukes, op. cit., vol. ii, George Bay p. 243 . 
and Bay of which the Micmacs travelled by the westerly route, and some Islands (where they of these goals ranked as independent but subsidiary bases. and some The first was St. George Bay, on the west coast, whose rivers English- men recent- rise close by the affluents of the Upper Exploits. Micmacs ly settled), already resided in St. George Bay for reasons the opposite of those which attracted them to their chief bases. They came thither by sea in their canoes from Cape Breton Island immediately after, and in consequence of, the Treaty of 1783 , under a chief, with British consent, and their object was not to escape from but to associate with British colonists who were already there, and with whom they afterwards intermarried. ${ }^{1}$ Similiar social reasons induced a Micmac mother of many daughters to migrate from St. George Bay to Humber Sound in the Bay of Islands, where a Dorsetshire father of seven sons, and another white patriarch and his numerous sons, were the only, or almost the only residents long before and for seventeen years after $1822 .^{2}$ A glance at the map will show a back way by fresh water from the Bay of Islands up the Humber River, Deer Lake, and Junction Brook to Grand Lake, whose feeders almost overlap the feeders of St. George Bay. This was a continuation of the western Indian way, and was known to the Micmacs from time immemorial, and through them to one or two and thence English trappers before 1839. There was also a continuation to Bonne, of this continuation which led from Deer Lake up the Upper Hall Bays; Humber, over a shallow portage, and down Indian Brook to Hall Bay on the north-east coast, where there were two or three English families in 1828 , and only some six families, chiefly Micmac, as late as 1878 . Many Micmacs and one English trapper used this last route long before $1841 .^{3}$. We read, too, of Micmacs varying or extending this trip by going

1 Lieutenant Chappell, Voyage of HI.M.S. Rosamnund, 1818, p. 76. Ante, p. $14^{\mathrm{I}}$.

${ }_{2}$ Jukes, op. cit., vol. i, pp. I00-1 I5, nom. Brake and Blanchard; and ante, p. I4I.

3 Bonnycastle, Nerefoundland in 1842 , vol. ii, p. 242 ; A. Murray and J. P. Howley, Geological Survey of Nerefoundland, 1881, p. 502; John MacGregor, op. cil., vol, i, p. 265. 
from St. George Bay direct to White Bay in order to visit a white priest, ${ }^{1}$ or by going from one of the sources of the Upper Humber across the main range to Bonne Bay in order to visit their relations. ${ }^{2}$ The western branch-route led upward and outward from the sources of White Bear River to St. George Bay, the Bay of Islands, Hall Bay, and Bonne Bay, where Englishmen and Micmacs associated with one another.

The main trunk-route led beyond Crooked Lake to a lake (2) northcalled Island Lake, which is the most northerly water belonging ward to the to the southerly water-system, and is believed at times to Exploits or overflow into Noel Paul's Brook, which falls into the Exploits a little below Red Indian Lake. This is the route which the this Micmacs followed in their war against the Beothics, and the the Beothics named Noel Paul's Brook 'Shannoc Brook', Shannoc being the name by which they knew the Micmacs. The ' grand Notre Dame Bay, route ' led straight into the heart of the enemy's country, and was therefore a war-route and was not used by the Micmacs in times of dubious peace. The neighbouring route by Great Rattling Brook also led to the Exploits, but to one of its lower reaches, and was therefore less useful in war though equally dangerous in so-called peace. Newfoundland Dog Lake, which is on the summit of the main trunk route, is only within half a mile ${ }^{3}$ of the source of the Gander River, which flows into Notre Dame Bay east of the Exploits, and also opens towards the east into a lake which furnishes a waterway to within a few miles of an inlet in Bonavista Bay miscalled Freshwater Bay; so that the descent of the Gander led direct to Notre Dame Bay, which their enemies frequented, and made Bonavista Bay, which was now English, almost equally accessible to the wanderer. Indeed, thirty years ago it was a common fallacy to suppose that the Gander flowed into both bays, and that Cape Freels was on a large island enclosed

1 Jukes, op. cit., vol. i, p. I 7 .

2 Royal Geographical Socicly' Journal, 1864 , vol, xxxiv, p. 263.

3 J. G. Millais, Newfoundland and its untrodden ways, 1907, p. 230 ; Murray and Howley, op. cit., p. 217. 
(3) or

north-eastzoard to Bonavista Bay, and south-eastroard to Placentia and other Bay's.

by two Bays and a river. In Cormack's time every northern route that led east of Hall Bay and Grand Lake, north of a line drawn between King George IV Lake and Island Lake, and west of the line formed by Great Rattling Brook and the Lower Exploits, was bolted and barred to the Micmac; even the Lower Gander was fraught with danger; for their implacable foes dwelt there or wandered there; so that for many years to come they only ventured into the forbidden enclave with fear and trembling and under the English aegis.

The third branch way led by Eastern Maelpeg Lake either to the source of the Gander, and so down the Gander directly to Notre Dame Bay or indirectly to Freshwater Bay, or down Terranova River into Bonavista Bay, a few miles south of Freshwater Bay. Cormack seems to have known only of the Gander-D'Espoir variation of this route ; and the Terranova -D' Espoir variation was mentioned-indeed the Terranova River itself was mentioned-for the first time in $18400^{1}$ This branch way admitted other variations and extensions, and in 1840 it was quite common for the Micmacs to strike the headwaters of Piper's Hole, close by the Isthmus of Avalon, from affluents of Eastern Maelpeg Lake, so that the Micmacs could reach though ' they are seldom or never observed on the eastern shores where the white man chiefly dwells'. ${ }^{2}$ They roamed from river to river between White and Bonne Bays and the Bay of Islands, St. George, White Bear, D' Espoir, Fortune, Placentia, Bonavista, and perhaps Gander Bays, even before their fear of the Beothics ceased; and after their fear ceased their travels were only shortened and multiplied; their arcs were turned into chords, and their rough paths were made smooth.

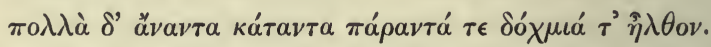

Englishmen made round trips

Their many ways led up, down, across, and athwart the body of the island, always by fresh water and never round its

1 Jukes, op. cit., vol. ii, p. I05.

2 Bonnycastle, op. cit., vol. i, pp. 2 I2, 2 I 3. 
coast. English colonists went from all these bays to all these by sea, bays, but always by salt water and round the coast; so that Micmacs by English progress outside the Peninsula of Avalon was exclusively marine. Micmac methods of progression in the same region were by rivers and lakes, exclusively inland, and, in early times, when the Beothics held the centre, almost as circuitous as English methods. Cormack's discovery was that the Micmacs had so completely monopolized, and Englishmen had so completely eschewed fresh water and land, that Englishmen, as they revolved in the outer circle, were in complete ignorance of the Micmacs, who were revolving in an inner circle. And yet 'overlanding ' is an essentially English instinct, and it would seem odd to find Londoners who thought that their only way to Bristol or Liverpool was by sea.

On the other hand, there was a difference between the and Micoverlanding of the Micmacs in Newfoundland and the travelled overlanding of the English colonists in other climes. English for mere overlanding always meant the creation and maintenance of purposes land-links between the extremities; Indians invariably kept and sport. the interval empty. The English process led to progress and fullness; the Indian process led to stagnation and inanition, for Diana, whom the Indians worship under another name, is not the goddess of population. Consequently in $1822,15^{\circ}$ Nicmacs and a few dying Beothics filled all that part of Newfoundland, which does not consist of peninsula and coast-line; in 1842 there were no Beothics, the Micmacs were $200,{ }^{1}$ and but for them the body of Newfoundland was like an empty skin; in 1872 the Micmacs were under $200 ;^{2}$ and less than 200 Micmacs, along with railwaymen and lumbermen still occupy - or rather pervade-the land. But for them the frame is without a picture. Indian colonization is the antithesis of solid progress, and like some gas keeps small particles of itself in vast spaces for centuries at a time.

1 Sir R. Bonnycastle, op. cit., vol. ii, p. 244.

2 Sir S. Hill, Keport, 1872, p. 47. 


\section{I7O HISTORICAL GEOGRAPHY OF NEWFOUNDLAND}

English colonization is also wont to pass through the hunting and travelling stage; but the hunter and traveller have invariably ushered in men of another type who have peopled the land.

Amongst

the colonia land-laws sporting and hunting laws are conspicuous, but antidog laws protect reindeer and sheep against sporting abuses.

A sludy of the inland districts helps us to understand not only the Micmacs but the Statute-book, much of which consists of laws instituting close times for Caribou (Feb. I to July $3 \mathrm{I}$; Oct. I to 20 ), beaver ( 1897 to I 910 ), foxes, unless caught for domestication (!) or propagation (!) (March $\mathrm{I}_{5}$ to Oct. I5), hares, rabbits, and imported animals like moose (1875-1912), black-game, and capercailzie (1886, \&c.). The country is dedicated to sport and the fur-trade, and furanimals include black bears, lynxes, ${ }^{2}$ and martens. ${ }^{3}$ On the other hand, under Acts passed in and after 1884 seventy or eighty localities have ordered every dog, except collies and mail-dogs, to be treated as wolves and destroyed. The dog ban has become necessary for the sake of other domestic animals, and the carnivore is sacrificed to the ruminant. Ruminants now include imported reindeer. The domestication of caribou was urged by Cormack (I 822 ), Jukes (I 840 ), Sir S. Hill ( 1873 ), and others, and has been practised with success for a year or two on certain occasions, ${ }^{4}$ and in $1907-8$ some Lapps were imported with tame reindeer from Lapland into St. Anthony in the north-east corner of Newfoundland, in order to realize these projects. But at present the domestication of the caribou seems almost as remote from the range of practical politics as the domestication of the fox. The peculiar victim of the dogs of Newfoundland has been the sheep.

Farming. At the beginning of this period, woodcutting was almost began seri. ously when Cochrane introduced roads, the only winter pursuit, and dogs were the only beasts of burden which the woodcutters employed. Then Admiral Sir

1 The American elk.

3 Whitbourne's 'wild cats' (?).

4 Jukes, op. cit., vol. ii, p. 90; Governor Sir S. Hill, l'eport, 18\%3 (c. 709, I), p. I4I ; Millais, op. cit., p. $334^{n}$. 
Thomas J. Cochrane, who, like General Macquarie in New South Wales, was the first Governor with a long spell of office (1825-34), devoted himself to road-making and agriculture. Some of the roads which he planned were local roads, and others were through roads. Two local roads were to lead from St. John's direct to Portugal Cove and to Topsail in Conception Bay, each of which would reduce a sixty-mile voyage by sea to a ten or twelve mile journey by land. Two similar roads from Carbonear to Heart's Content, and from Spaniard's Bay to New Harbour, were to cut off the neck of the peninsula which separates Conception Bay from Trinity Bay. In addition to these local roads, there were to be two through roads from St. John's, one of which was to go by Topsail to Holyrood at the head of Conception Bay, going thence either to Placentia, which was then, and is now a town of small importance, or else to Carbonear via Harbour Grace, which was three miles from Carbonear, and was then, and is now the second town in Newfoundland. Sir T. Cochrane also built a road three miles out west from St. John's, which was meant to go north to Torbay along the line of a rough disused military road and south to Ferryland. But things that are of the earth earthy move slowly in Newfoundland, and these through roads were not complete until the Fifties, when Wood's Almanac advertised a 'couch' (sic) running twice a week to Carbonear, and wagons running once a fortnight to Placentia and Ferryland from St. John's. But a stimulus was given to the construction and maintenance of the local roads which have been mentioned and of other local roads, of which that between New Harbour and Spaniard's Bay was a fair track in I828, and those between St. John's and Portugal Cove, Carbonear and Heart's Content, Brigus and Carbonear, Placentia and Little Placentia, Ferryland and Renewse, were in working order $(1840)$ long before the trunk roads of which they were meant to be parts or adjuncts were complete. The road between Brigus and Carbonear was 
sixteen miles in length and was considered in $184^{\circ}$ 'the longest piece of road in the island'.'

which introduced horses which introduced oats and hay and replaced dogs.

After roads came horses. 'They are making roads in Newfoundland,' said Peter Ougier, 'next thing they will be having carriages and driving about.' In 1840 horses were just coming into general use in the neighbourhood of St. John's and were supplanting dogs. But horses required oats and hay. Consequently the incipient roads were lined with oatfields and hayfields. Cattle and sheep began to increase ; in I 849 the Governor and the Agricultural Society-which was formed in $184 \mathrm{I}$ under the auspices of the Governor and with a State subsidy-imported a man and woman to teach spinning and weaving, and an Ayrshire bull and two cows; but owing to the dog-pest there were only seven sheep to ten kine at that date. When horses came in and dogs went out sheep were to kine as ten to seven (I869), or ten to five (I88I), and after the massacre of the guilty dogs, ten to four. The same Society introduced 'ploughs, harrows, and agricultural implements' $(1848)$ which were at that date 'little known' near the capital, and unknown elsewhere. ${ }^{2}$

Settlers Military officers who can be named used to farm within nowe began reach of their barracks. ${ }^{3}$ Then prominent settlers like here and Dr. William Carson, Sir J. Pearl, H. P. Thomas, Robert Pack, there; and Mackinson followed suit in the immediate neighbourhood of St. John's, Carbonear, and Brigus. ${ }^{4}$ On isolated points on the coast between Trepassey and St. Mary Bay, and between Placentia and Fortune Bays, there was open ground, with cattle-stations of fifty or sixty cattle apiece in $1842 .^{5}$ In 1828 fresh meat had just fallen from two or three shillings a pound to sixpence or sevenpence a pound; and in $184 \mathrm{I}$ we are told ${ }^{1}$ Jukes, op. cit., vol. ii, p. 70 ; E. Gosse, Life of P. Gosse, 1890 , p. 68 .

2 Sic Sir G. Le Marchant, 1849 .

3 Ante, p. $15 \mathrm{I}$.

4 Patrick Morris, Short Review of the History of Newfoundland, 1847 , p. 71 .

${ }_{5}$ Sir R. Bonnycastle, op. cit., vol. ii, p. 28 and map; Jukes, op. cit., vol. i, p. 88 ; Captain Loch's l'eport, 1849 , No. 327. 
that rich people had for the last ten years or more been eating fresh beef and mutton all the year round. ${ }^{1}$ Cattle-farmers supplied the classes before the roads were complete. But these farmers were mere forerunners, and it was after the making of roads that farming seemed about to become an institution. In this sense roads created agriculture. ${ }^{2}$ Roads, horses, cattle, oats, and ploughs brought wheat, but wheat culture was and still is in its infancy. A skilled observer wrote in $184^{2}$ of a farmer who had a water-mill, and grew and ground autumn-sown wheat near St. John's, as though he were one of the wonders of the world; and in I849 Sir G. Le Marchant triumphantly announced his discovery of no less than three mills in Newfoundland, one of which, however, was not yet in use. ${ }^{3}$ Oddly enough, Sir T. Cochrane had made the same discovery of the same corn-mills some sixteen years earlier. Farming, if any, was usually mixed farming, not only in the English sense, but in the sense that farmers were only half-farmers, half-something else. Jukes discovered 'one of the very few instances in the island' of a farmer 'entirely independent' of that something else; ${ }^{4}$ but this unique specimen dwelt in a unique position on an islet of his own near Greenspond, which was his market, and which was then and is now one of the principal settlements in Bonavista Bay. People did not think it worth while to farm seriously; partly because other pursuits were more lucrative and congenial, and partly because, as a rule, the soil was ungrateful. But to this last rule there was an exception in the neighbourhood of St. George Bay, and in the big river valleys. The reasons which made for fertility were geological.

A glance at the map of Newfoundland will show land, Geological mountains, rivers, flats, bays, and everything else sloping preventing

1 Bonnycastle, op. cit., vol, i, p. 262 ; P. Morris, Arguments, 1828 . it from

2 Bonnycastle, op. cit., vol. ii, ch. ix ; Sir J. G. Le Marchant, Report, general, $1847-8$.

${ }_{3}$ Bonnycastle, op. cit., vol. ii, pp. 18, 19; Sir G. Le Marchant, Report, 1849. 'Jukes, op. cit., vol. ii, p. 113 . 
from south-west to north-east more or less. The geological directions are similarly aslant and parallel, and the coloured geological map is striped like a tiger. A narrow band of Laurentian gneiss and granite runs north-east from Hermitage Bay or thereabouts to Cape Freels or thereabouts. Before I 763 the resident population was almost entirely confined, and three-fourths of the population still reside east of this band. This eastern district consists almost entirely of Huronian sandstones, slates, and the like, overlain here and there by Primordial or Lowest Silurian rocks. The Laurentian rocks are the lowest known rocks, and pure Laurentian country is normally barren, resembling the Scotch Hebrides ; Huronian strata are only a little higher in the geological and agricultural scale; and 'Primordial' and 'Lowest Silurian' rocks, which are higher still, yield limestone, sandstone (of which the beautiful Roman Catholic Cathedral at St. John's is built), and contribute most, if not all of the mineral wealth of the land, but are of little agricultural use. West of this Laurentian band more fertile strips, chiefly of Silurian formation, cross the country along the lines of the great rivers which flow into Notre Dame Bay, and their fertility is attested and their development arrested by forests of timber-trees, similar in kind but superior in stature to those which disadorn the Huronian region. The valley of the Exploits River-from its mouth to its source two hundred miles away-is one of those strips, and the strip is prolonged from the source of the Exploits southward to La Poile Bay, which is only twelve miles away. The interstices between these fertile strips are filled mainly with Laurentian 'barrens'. Behind these Silurian strips is the main range, which extends from Cape Ray to Belle Isle and other islands between Newfoundland and Labrador, and the backbone of the main range is Laurentian. Behind the range is the west coast, which, narrow though it is, has more modern and variegated formations than all the rest of the country put together. Thus the highlands from Cape 
Anguille to St. George Bay consist of carboniferous limestone and contain coal-measures; and limestones, newer than those of Conception Bay but older than those of Cape Anguille, occur on the Humber Arm of the Bay of Islands, and these and other rich materials are strewn over the western, and even at times over the eastern, flank of the great range, reappearing, for instance, on the singular flat which runs north-east from Deer Lake and Grand Lake towards Hall Bay. It should be added to this brief sketch that other thin Laurentian strips run through Avalon Peninsula, and behind Trinity and Bonavista Bays; that Lower Silurian formations dot the coasts of Bay D'Espoir in the south and Notre Dame Bay in the north-east; that granite, serpentine, and trap of uncertain age intrude intermittently and from time to time, but more especially on the Lower Silurian Strata, ${ }^{1}$ and that all these rocks point in the same prevailing direction. Even on the west coast, which has the latest rocks, there is no rock later than that which is classed in Europe as Primary, so that the geological history of Newfoundland like that of Nova Scotia stopped short in the earliest ages, and was even more primitive than its political history.

Being then the most modern and varied in its structure, it except e.g. might be thought that St. George Bay and the Bay of Islands and their neighbourhood would attract farmers; and in these parts there has been a little spontaneous farming. Thus on parts there has been a little spontaneous farming. Thus on in early
the Great and Little Codroy Rivers to the south of St. George times; Bay, as on Cape Breton Island, Highland Gaels were cultivating the Highlands; farmers' wives were spinning, weaving, and knitting home-grown wool; and wheat, oats and barley were grown during the Forties, ${ }^{2}$ so that the future may verify

\footnotetext{
1 e. $g$. in the Lauzon subdivision of the Quebec division of the Lower Silurian strata.

2 Bonnycastle, op. cit., vol. i, p. 209; Captain Loch's Report, Accounts and Papers, I 849, vol. xxxv, p. 493, No. 327 ; J. Canning's Report, Accounts and Papers, 1857, vol. xvi, p. 519, No. 2201 ; England, Church in the Colonies, Journals by Bishop Feild, \&c., No. 25 , 1849, pp. 35-8; London, Royal Geographical Society's Journal, vol. $x \times x i v$, p. 269 .
}

in the south-west, where there were farms times; 
the prophecy of Sir Stephen Hill, ${ }^{1}$ who said that this district could and would before long maintain 350,000 people ( 1873 ); but its present population is under 10,000 , most of whom are busily engaged on pursuits very different from agriculture.

and in the Exploits and other valleys where lumberers (I) worked and for purposes of boat-building and more recently of shipnear the sea building. In I804, 30 ships, averaging 73 tons, were built ships; in Newfoundland. Between 1826 and 1839 the ships averaged 26 per annum, and the tonnage 62 tons; and in I 846 the ships were $3 \mathbf{I}$ and the tonnage 55 tons. It will be remembered that the average tonnage of the west-country sailing ship was 57 tons and 74 tons in the sixteenth and seventeenth centuries respectively, ${ }^{2}$ and it might be thought that Newfoundland was going backward from the seventeenth to the sixteenth century standard. The explanation of this anomaly is that the ships were put to different uses in 1804 and $1846 ;^{3}$ and that in $r 846$ builders practised self-help to an extent hitherto unknown, instances being known of growing trees being converted into ships of over 50 tons by the unaided efforts of one man and his young boys. ${ }^{4}$

(2) did the In the Seventies a new demand for ships-of which more same on a largerscale, as capitalists, and began to go inland; , a anon-arose; steam-mills, timber licences for one year of six square miles, ${ }^{5}$ and bounties on certain local ships, ${ }^{6}$ were introduced; and one steam-mill at the mouth of the Exploits in Notre Dame Bay ( $187 \mathrm{I}$ ), a second on the Gambo (or Triton) in Bonavista Bay (1876)-the latter being in charge of a lumberman from New Brunswick-and a third, on an

1 Report, 1873, p. I34.

2 Ante, p. $4 \mathrm{I}, 84,105$.

4 Sir J. H. Glover, Accounts and Papers, I878-9, vol. 1, p. II (c. 2273 ).

5 Statutes of Nervfoundland, 38 Vict., c. 3 .

$6 \$ 6$ per ton, 39 Vict., c. 5 . 
islet in Hall Bay (1879), ministered to the new demand. Capitalism and brother colonists had arrived. The ships were for the use which will be presently described, were 40 tons or so, and were turned out at the rate of 128 a year (1876-80). It is during this decade that we first hear of inland residents, and Howley wrote in 1876 that 'there is scarcely a habitation anywhere situated five miles from the salt water, with the exception of one small settlement recently commenced by some lumberers at the head of Deer Lake'.1

In the Nineties a new use was found for lumbering, and a local law authorized 99 years' timber-leases of tracts of from 5 to ${ }_{5} 5^{\circ}$ square miles on payment of $£_{7}$ ros. per square mile every twenty-five years, and on condition that the lessee should spend $f_{612}$ ros. per square mile on building pulp or paper factories $(1890){ }^{2}$ About the same time the Exploits Lumber Company acquired 500 square miles of timberland. A new day dawned for the lumberman, and the land-grant railway companies of the Nineties only accelerated a process which had already begun.

In 1880 the State projected a State railway from St. John's northward to Hall Bay, and handed over the task of constructing it to an American Syndicate, to which it granted nected with 5,000 acres along the line (or elsewhere) in fee-simple for railway developevery mile of railway which was constructed. If the land ment); was selected opposite the railroad it was to be eight miles deep for every mile of frontage, and to alternate with similar blocks which were reserved by the State. The State undertook to promote emigration and to enable aliens to hold lands in fee-simple. In $\mathbf{r} 889$ the Newfoundland Railway Company, as the Syndicate was then called, had only constructed their main line as far as Whitbourne, with a branch thence to Harbour Grace, so the State resumed possession

1 J. P. Howley, Geography of Nerufoundland, I 876, p. 2.

253 Vict., c. I.

vol. v. PT. IV 
and boldly announced its resolution to do the work itself. Immediately after the announcement a Canadian capitalist, Mr. Reid of Montreal, who afterwards assigned his rights to the Reid Newfoundland Company (I90I), undertook to construct, equip (1890), and operate, during ten years (1893), a railway via the Exploits River to Port-aux-Basques in the far south-west, in lieu of Hall Bay, on terms similar to those conceded to the American Company, in other words for some 3,000 or 4,000 square miles of land. Next Mr. Reid took over from the Government a branch line which it had constructed to Placentia $(\mathbf{r 8 8 7}-8)$, and the branch line to Harbour Grace; and agreed in 1898 and $x 901$ to work and maintain these lines, and all the other lines in the colony, until 195r. Reconstructions of old railroads, steam-service up the west and east coasts and along the coast of Labrador, Bay-boats, the mail, the Government telegraphs, the dry dock at St. John's (built in I 884), and the St. John's electric tramways and pavements were thrown in to the contract of

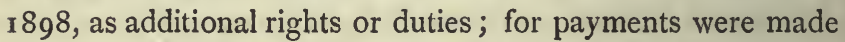
both by and to the contractor, so that no clear distinction was drawn between rights and duties, and although all men agreed that the essence of the contract was to convert the State into a Man, they differed as to whether the Man should be looked on as an incarnate Atlas or Leviathan. Two of the undoubted rights which he received under the concession were a right to select additional land as before to the extent of 5,000 acres per mile (or 2,500 acres per mile for the few miles between Whitbourne and Tilton), and a right to buy the freehold reversion of the railway on reassignment by him to the State of one-half of the additional land conferred by the contract of $\mathbf{r} 898$; but he renounced these two rights, and also re-sold the telegraphs to the Government for $\AA_{370,000 \text {, in }}$ 1901. That is to say, the land claims of the Company were cut down to their original 3,000 or 4,000 square miles, to be selected either in alternate blocks of one mile frontage to the 
railroad with eight or ten miles depth behind the frontage, or elsewhere. Canadian superseded New York capital, and success resulted. Reid's railway route is semicircular like a horseshoe or new moon, links east and west, touches the head of every important eastern and western bay except in Petit Nord-as the chimney-shaped peninsula which shoots up north from Bonne and White Bay is still called-and has made the country, except Petit Nord, one country. It has multiplied branch roads, for instance, between the head and foot of Trinity Bay, and has assisted, though it did not initiate, the lumber movement of the Nineties. In 1890 the first inland village in Newfoundland sprang into life around a saw-mill on the Exploits, and around Reid's railway stations on the Gambo, Gander, and Exploits, townships modelled on the Canadian system were marked out and lumber villages grew up. These townships on the railroad were the first examples of colonization by townships in the history of Newfoundland.

In 1905 a new pulp-and-lumber-concessionaire entered (4) or upon the scene in the person of Messrs. Harmsworth alias worked inthe Anglo-Newfoundland Development Company, alias the land under Daily Mail of London; which took a 99 years' timber and cussions mineral lease of the area drained by the Exploits and not 10 mamoccupied by the Reid Newfoundland Railway Company or velopment the Exploits Lumber Company, at $8 s$. per square mile per companies. annum, plus royalties on timber cut and minerals won, and subject to a condition to spend $£_{150,000}$ in twenty years on pulp or paper mills; and since 1905 the spirit of a modern newspaper has brooded over scenes once haunted by the Beothics. In 1908-9 dams and reservoirs were opened by the Company on the Exploits at Grand Falls which is now the principal inland settlement in Newfoundland. Similar pulp concessions were granted to others on the Gander and Terra Nova and at Conne Bay in 1909-10. The new policy of the Nineties was to bring in settlers, and Canadian or English 
Railways were also connected with mineral development;

capital. Pulp or paper was the mask and internal development was the face behind the mask. At present lumbering has given over large areas to mammoth companies and has created a brand-new export, of which we hear for the first time in I890. On the other hand, the age of paper has not superseded the age of shipbuilding; a three-mile belt along the shore is reserved where men felled trees and built $13^{6}$ 36-ton ships in 1906 as in the Seventies; and within this belt timber-licences are issued without payment.

Railroads were built for the sake of minerals and coal as well as timber, but coal belongs to the future, and minerals, by some freak of fate, cleave like the rest of the civilization of Newfoundland to the rocks upon the coast. The mineral history of Newfoundland began in 1857 , and it was associated at its birth with telegraphs. The first successful telegraphwire from east to west was laid by the New York, Newfoundland, and London Company, which was incorporated in 1854 , and which finally succeeded in connecting London, Heart's Content, Port-aux-Basques, Cape Breton Island, and New York in 1866. It was financed from New York, its concession was for fifty years, and it received land-grants along its line. One of its land-grants included the lead-mine of La Manche at the head of Placentia Bay, which started work in 1857 , produced 1,000 odd tons in $185^{8}$ and 1859 , and became the property of the Newfoundland Colonization Company in $188^{\circ}$. It was in 1857 , too, that Smith McKay noted copper at Tilt Cove, a few miles south of Cape St. John; and it was there in 1864 that he and C. F. Bennett began work. Immediately 500 people sprang up like mushrooms on this desolate shore. ${ }^{1}$ In 1879 Betts Cove, a few miles further south-east of Cape St. John, was the first, Little Bay, which is somewhat further east, was the second, and Tilt Cove the third copper centre. Like Tilt Cove, Little

1 Governor Sir $\Lambda$. Musgrave, Report, 1867-8, vol, xlviii, p. 121, No. 3995 . 
Bay became populous as if by magic ( 1878$)$; in July it was uninhabited, and in October it had a town with 500 in. habitants. ${ }^{1}$ Next, Pilley's Island, which is in the same neighbourhood (1888), and Bell Isle in Conception Bay (1896), began to yield iron; and the iron of Bell Isle, which had been foreshadowed in $1819,{ }^{2}$ was quarried by a Nova Scotian Company. Other discoveries have recently been made close by the sea-shore: of oil at Parson's Pond, Bonne Bay, of copper in Hare Bay, of coal behind Forteau Bay in Labrador, and of iron and other minerals elsewhere, which it would be premature to discuss. Mining, too, has encouraged roads and farms, but like lumbering its essential importance is that it has created a brand-new export out of nothing.

Dates and maps will show that the mineral development zolich was independent of the railways which were built, but a again is new scheme was sanctioned in 1907 , and provided that new railMessrs. Ochs and Dalglish, of London, should sail steamers ways. on what is alleged to be a fogless route from England to Green Bay in the very heart of the copper district, and should build a railway thence to Bonne Bay, and should sail steamers thence to Gaspé or elsewhere, the route being changed in winter. Land-grants of 1,500 acres per mile, with a maximum of 195 square miles, and 25 years' subsidies, were allowed. A branch railway from the first railway through Petit Nord to Belle Isle Strait, and a tunnel or a service of ice-breaking steamers across the Strait to Labrador, were also authorized. But at present this branch railway seems almost as visionary as the railway along the north coast of the Gulf of St. Lawrence and the east coasts of Labrador, which a London Company obtained power to construct from the Government of Newfoundland in 1890 , but which no one has ever attempted to construct.

Telegraphs, railroads, lumbering, and mining have in-

1 So Murray and Howly,"op. cit., pp. 498-9.

${ }^{2}$ Anspach, Hist. of Nervfoundland, 1819, p. 368. 

All these directly, and a series of 'Acts for the reduction of pauperism
develop. ments, by encouraging agriculture' (r860, r866, \&c.) have, by combined bounties and gifts, directly promoted farming, and under one with bounties, have promoted agriculture, of these Acts (1886) thirty families were settled near Dildo Pond, and similar small results have been obtained elsewhere. The poor-law was the cradle in Europe of manufacture, and in Newfoundland of agriculture, which, despite incessant rocking, is still in its infancy.

and mame- Bounties, too, have been showered on manufactures ever

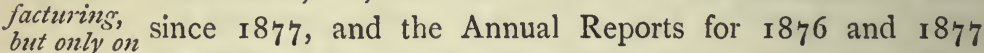
a small pointed to three biscuit, one tobacco, and two machine scale.

factories as the latest novelties in St. John's; and a ropewalk, for making cordage, a nail factory, a woollen factory, and a tanyard were added in $\mathbf{1} 882$ and $\mathbf{r} 883$. Even now manufactories are still in the stage in which they can be counted and named by the passer-by. The reality of the manufacturing, agricultural, mining, and lumbering may be gauged by the following three tables.

\section{ExPORTS.}

\begin{tabular}{|c|c|c|c|c|c|c|}
\hline \multirow[b]{2}{*}{ EXPORTS } & \multicolumn{2}{|r|}{$£ \times 1, \infty 00$} & \multicolumn{3}{|c|}{ Fïve jear averages. } & \multirow{2}{*}{$\begin{array}{c}\begin{array}{c}\text { Last availab } \\
\text { year. }\end{array} \\
1907^{-8}\end{array}$} \\
\hline & I $88 I-5$ & I $886-90$ & $x 89 x-5$ & $1896-1900$ & $1901-5$ & \\
\hline $\begin{array}{l}\text { Copper } \\
\text { Iron } \\
\text { Wood }\end{array}$ & $\begin{array}{l}5^{8} \\
\text { nil } \\
\text { nil }\end{array}$ & $\begin{array}{r}533 \\
8 \\
\text { nil }\end{array}$ & $\begin{array}{l}81 \\
38 \\
\text { Io }\end{array}$ & $\begin{array}{l}90 \\
52 \\
12\end{array}$ & $\begin{array}{r}87 \\
163 \\
37\end{array}$ & $\begin{array}{c}5^{6} \\
24^{0} \\
5^{2}\end{array}$ \\
\hline Total & $5^{8}$ & 61 & 129 & I 54 & 287 & $348^{2}$ \\
\hline $\begin{array}{l}\text { Percentage of } \\
\text { Total Exports }\end{array}$ & $4 \%$ & $5 \%$ & $10 \%$ & $12 \%$ & $14 \%$ & $14 \%^{3}$ \\
\hline
\end{tabular}

1 Includes lath.

2 If dollar $=4 s .1 \frac{1}{b} d$.

3 Ditto in 1906. 
II. IMPORTS.

\begin{tabular}{|c|c|c|c|c|c|c|}
\hline \multirow[b]{2}{*}{ IMPORTS. } & \multicolumn{5}{|c|}{$£ \times 1,000$. Five year averages. } & \multirow{2}{*}{$\begin{array}{c}\begin{array}{c}\text { Last available } \\
\text { year. }\end{array} \\
1907-8\end{array}$} \\
\hline & $188 \mathrm{I}-5$ & $1886-90$ & $1891-5$ & $1896-1900$ & $1901-5$ & \\
\hline $\begin{array}{l}\text { Flour and Butter } \\
\text { Meat, Dead } \\
\text { Cottons, Woollens, \&c. } \\
\text { Coal }\end{array}$ & $\begin{aligned} 418 \\
I_{3} 33 \\
242 \\
40\end{aligned}$ & $\begin{array}{r}344 \\
125 \\
187 \\
43\end{array}$ & $\begin{array}{l}319 \\
\mathrm{II3}^{313} \\
2^{13} \\
4^{1}\end{array}$ & $\begin{array}{c}309 \\
98 \\
203^{1} \\
4^{1}\end{array}$ & $\begin{array}{l}326 \\
131 \\
2281 \\
88\end{array}$ & $\begin{array}{l}381^{2} \\
227 \\
224 \\
132\end{array}$ \\
\hline Total & 833 & 699 & 704 & $6_{5} \mathrm{I}$ & 673 & 964 \\
\hline $\begin{array}{l}\text { Percentage of } \\
\text { Total Imports }\end{array}$ & $50 \%$ & $52 \%$ & $49 \%$ & $52 \%$ & $38 \%$ & $41 \%$ \\
\hline
\end{tabular}

${ }^{1}$ Includes apparel.

${ }^{2}$ Excludes butterine material.

III. FARMS.

\begin{tabular}{|c|c|c|c|c|c|c|}
\hline & 1836 & 1845 & 1869 & I88I & $189 \mathrm{I}$ & 1901 \\
\hline $\begin{array}{l}\text { Square miles 'Gardens' } \\
\text { and Pasture } \\
\text { Horses } \\
\text { Cattle } \\
\text { Sheep }\end{array}$ & $\left\{\begin{array}{l}17^{*} \\
1,551+ \\
5,835 \dagger \\
3,103 \dagger\end{array}\right.$ & $\begin{array}{r}46 \\
2,409 \\
8,135 \\
5,75^{\circ}\end{array}$ & $\begin{array}{c}65 \\
3,764 \\
14,726 \\
23,044\end{array}$ & $\begin{array}{c}65 \\
5,436 \\
19,884 \\
40,326\end{array}$ & $\begin{array}{c}34 \\
32 \\
6,139 \\
23,828 \\
60,853\end{array}$ & $\begin{array}{c}60 \\
55 \\
8,851 \\
32,767 \\
78,052\end{array}$ \\
\hline
\end{tabular}

* Three square miles in I8I3; ante, p. I52. Chiefly potatoes and vegetables.

† Bluebook, 1837 , omits Fogo, Twillingate, and Treaty Shore.

The third table speaks for itself. The second table, ${ }^{1}$ supplemented by the annual statistics of the colony, proves that Newfoundlanders are fed on meat, bread, and butter by

${ }^{1}$ Summarized in the annual Statistical Tables of the British Colonies. 
the United States and Canada almost equally, ${ }^{1}$ and are clothed by England, and that three-fourths of the coal which drives their steam-engines is derived from Nova Scotia, and the rest of it from the United States and England. The first table, supplemented as before, shows that the only important produce of the soil is exported, that it represents at most only one-seventh of the industry of the country, that half of it goes to Canada and the rest in unequal thirds to the United States, England, and Holland ; that the whole of it would not even pay the bread-bill ; and that the attempt to read Newfoundland like a book from the inside only throws a faint light on a minute fraction of its industrial life.

Political progress was from a nominee Council, $1825-32$, to representative, I 832 , and responsible government, 1855 ,

Political history had almost as little to do with land as industrial history. From 1818 to 1825 , Sir C. Hamilton, who was permanent resident Governor and Commander-in-Chief of the naval station at Newfoundland, ruled without a Council. From 1825 to 1832 , which was the year of the English Reform Act, Sir T. Cochrane, who was the new Governor, happened to be a Captain in the Royal Navy, and governed with the assistance of a nominee Council. Then Sir T. Cochrane inaugurated Representative institutions, and from $183^{2}$ to 1855 there was a Legislative and Executive Council, consisting of about ten officials or nominees, and a Legislative Assembly, consisting of fifteen representatives of nine electoral districts ; and in accordance with a suggestion by Earl Grey, ${ }^{2}$ and revived by Earl Derby ${ }^{3}$ and Sir J. Harvey, the two Chambers sat together from I 843 to 1847 , like the Assembly of Guiana, and like several of the Assemblies of the old American Colonies. Responsible Government was introduced into Newfoundland in the same year (1855) as it was made law in Eastern Australia. Immediately the nine original electoral districts were increased to fifteen, and the fifteen members to thirty, but the change was more apparent than real. Thus

1 U.S. $5^{2}$ per cent. : Canada 42 per cent.

2 Then Lord Howick, July 27,1832 .

3 Then Lord Stanley. 
St. John's was split into two, and Conception Bay into five constituencies, so that seven constituencies in the new list represented five constituencies in the old list. On the other hand one of the additions of 1855 , and many additions, which have been made since 1855 , are of historical importance; thus the constituency of La Poile-and-Burgeo, on the west of the south coast, was added in 1855 , St. George Bay, White Bay, and Bonne Bay, ${ }^{1}$ on the Treaty Shore, were added in $\mathbf{I} 878$, and Fogo was severed from Twillingate in $188_{5}$, all of which changes were due to movements of population, occasioned partly by mineral development in Green Bay and its neighbourhood, and partly by the settlements on the Treaty Shore, whose origin and progress will be discussed in the next chapters. At present there are eighteen constituencies and thirty-six members, and the Legislative Council contains eighteen nominated members.

The electoral districts of Newfoundland are unique in two but the respects. They are, as a rule, coast-lines or islets, and nothing more, and the mainland is described as if it consisted of one dimension. The founders of the Constitution seem to electoral districts cleave to the coast, have assumed that it was inconceivable that any one could live anywhere except by the sea. Now and then other points of view are grudgingly and tardily adopted; thus St. John's District always included the road to Broad Cove and the peninsula on the north of it, and in 1889 and 1897 the borders of the districts of Trinity Bay, Bonavista Bay and Twillingate were enlarged to include the railroad across the island. Otherwise there seems to be a fixed idea that an electoral district must be a Bay or something very like it.

Secondly, up to a few years ago there were no political and there divisions or units of Government except the electoral divisions. are no local They were the basis of the census and of road-appropriations. tions except Taxes and road-, water-, and sewer-rates were levied by the John's Central Government. Calamity has to some extent fostered munici- 
municipal institutions. Thus St. John's has been burnt twice during this period. After the first burning (1846) an Act was passed for the rebuilding of St. John's, and this Act, like a similar Act in English history (I666), paved the way for, although it did not create municipal institutions. A fire brigade and a water company were organized, and the latter built sewers as well as waterworks, and administered the coal-dues and water- and sewer-rates which the Governor-inCouncil levied. Nor was this state of things altered, except in name, when in I 888 St. John's obtained a Town Council without power to collect its revenue. The second great fire occurred in 1892 , and the second step was taken in I902, when the Town Council of St. John's became wholly elective, with power to raise what it spent, ${ }^{1}$ and to provide for its local indebtedness, which was held to include amongst other things the debts incurred for paving and for tramcars, to which reference has been made. The municipal movement has communicated itself to Harbour Grace, Carbonear, Heart's Content and Twillingate, which are, however, still in the stage of evolution to which St. John's was promoted in consequence of the first of these two fires. ${ }^{2}$

road loards,

Local Government Acts of general application were passed in 1897 and 1898 . Long before these Acts were passed nominee road-boards were appointed in the electoral Districts to distribute appropriations voted by the Legislature for local roads. The new Divisional Local Boards of $1897-8$ are elective, but are only entitled to receive and not to demand financial aid, so that they are little more than the old road boards under another name. In 1855 coping-stones were placed upon the Constitution, yet the humble offices on the ground floor are still almost wanting. Being built from the roof downwards, self-government has not yet reached so far.

and Ecclesiastical institutions have shown more local vitality.

Churches, and schools.

\footnotetext{
1 Statutes of Newfoundland, 2 Edw. VII, c. 6, s. I27.

2 Statutes of Newfoundland, 2 Edw. VII, c. 8 ; 8 Edw. VII, c. 8.
} 
In 1839 the first Anglican bishop of Newfoundland was appointed; a Roman Catholic bishop became resident in St. John's in 1796 , a second in Harbour Grace in 1856 , and a third at Sandy Point, St. George Bay, in 1892 ; and the Wesleyans were only a little less omnipresent than the Anglicans. In 1854 the two Protestant bodies only just outnumbered the Roman Catholics, although they outnumbered them in 1869 by four to three, and in 1901 by thirteen to seven. Grants were made during the whole of this period to religious bodies for purposes of education; accordingly each of the three leading religious bodies divided the land into local religious districts, which now aggregate 180 in number, and amongst which it distributed its educational receipts; and it would seem almost as though in Newfoundland, as in England, the ecclesiastical preceded the civil parish as an administrative unit. But in Newfoundland there are three principal Churches-Roman Catholic, Anglican, and Wesleyan-not one Church as in ancient English history. Scotch Presbyterians exist, but hardly any Scotchmen came to Newfoundland until last century, so that they are still very scarce. Indeed, Protestants who are not Anglicans or Wesleyans barely exceed ro,000. In spite of the dearth of local institutions, the people have shown an instinctive capacity to live together in peace without law or order, but these very instincts have at times led to breaches of the peace unlike those that have occurred in any other colony.

Perfect religious tolerance has prevailed in Newfoundland Religion during this century, but the population was largely of Irish formected $_{\text {affect }}$ origin, and political parties for a time ran on religious lines of politics and cleavage. In $r 83^{2}$ the Roman Catholic bishop of St. John's led to riots. advocated the candidature of his relative John Kent for a seat in the Assembly. His action was natural, though indiscreet; an outcry was raised, and Henry Winton, the editor of the Public Ledger, became conspicuous by his denunciation of the priest in politics. In May, $\mathbf{1 8 3 5}$, as Winton was riding 
along the three-mile road between Carbonear and Harbour Grace in broad daylight, ${ }^{1}$ he was felled to the ground by a gang of painted or masked ruffians, and his ears were cut off. The same penalty was inflicted shortly afterwards at the same place in the same month under the same circumstances on his foreman. It was said that the name of the ringleader of the outrage was known to every clerk in every countinghouse in Carbonear, but nothing was done. ${ }^{2}$ In 1840 there were election riots at Carbonear, in which a magistrate was attacked in presence of a huge mob and all but killed. No one was punished. It was about this time that a Judge of the Supreme Court was, at the instance of John Kent, sent to prison by the Speaker of the Assembly for having granted a writ of habeas corpus to Dr. Kielley, a local surgeon whom the Speaker had illegally sent to prison. ${ }^{3}$

In 186r John Kent, while Colonial Secretary, accused the Governor, Sir A. Bannerman, of conspiracy with the judges to defeat a Government Bill. The Governor dismissed the Ministry; a general election ensued, and, when the new Assembly met, a riot broke out in St. John's, during which houses were wrecked and looted, and the soldiers of the garrison were called out, stoned, and shot at, and then they shot back, killing three people and wounding twenty. The great bell of the Roman Catholic Cathedral tolled to prayer, the mob melted away, and peace was suddenly and completely restored. This act of righteous severity was the last act and deed of the garrison, which, in accordance with the policy applied to every self-governing colony by the English Government, left Newfoundland for ever in 1870 amidst universal regret. There was an afterglow of popular passion at Harbour Grace in $\mathbf{1} 883$, when four men were killed during a riot caused by rival religious processions; but since the

1 Shortly after 4 p.m. See Public Ledger, June 2, 1835 , cited by C. Pedley, History of Nerefoundland, p. $39^{2}$.

${ }_{2}^{2}$ E. Gosse, Life of P. H. Gosse, p. $8 \mathrm{I}$.

3 1842, Kielley v. Carson, Moore's Privy Council Cases, vol, iv, p. 63. 
Sixties Protestants have far outnumbered Roman Catholics, ecclesiastical have ceased to coincide with political factions, and these blots upon the history of the colony have been removed like so many others by the birth-rate. Except in I 88I, when anti-railway mobs went about wrecking railway property, mob law has not broken out; although groundless fears of violence were expressed in 1894-5 when the Banks broke.

An official Savings Bank was established in 1834 , with the The Bank Colonial Treasurer as its cashier and members of Council and ${ }_{1894-5}^{\mathrm{rash}}$, of the Assembly in equal numbers as its directors; and Post producced Office Savings Banks were established in 1882 . The first a fear of Commercial Bank was established in 1836 , and in 1894 two many other banks monopolized the banking business in the colony, namely, expectathe Union Bank and the Commercial Bank, which had been established in 1854 and 1857 respectively. At the close of 1894 and in the beginning of 1895 both of these banks suspended payment, and at the time of this suspension the

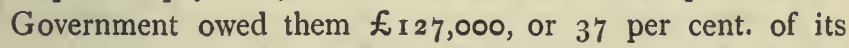
revenue, the two banks owed the Savings Bank $£_{208,000 \text {, }}$ and the Savings Bank owed the Bank of Montreal $£_{20,000}$.

Everything was threatened-solvency, revenue, thrift, the but only entire currency, and perhaps peace. Rumours were rife that transferred Newfoundland was about to become a Province of the funpremacy Dominion of Canada. The Colonial Government telegraphed to Canada. home for a loan of $£_{200,000}$ and a warship in case of disturbances. In response to this demand a civil servant, named Sir H. Murray, was sent out with $£_{20,000}$. The plague was stayed, and the history of the money affairs of Newfoundland turned over a new leaf. Specie to the extent of $£_{190,000}$ was imported; the Banks of Montreal, of Nova Scotia, and the Royal Bank of Canada, became the three paramount banks, and the financial sceptre passed to Canada. But Newfoundland remained as far off as she ever was from political union with Canada. Capitalistic enterprises of a terrestrial character 
concentrated in Canadian hands. But the destinies of Newfoundland are little influenced by terrestrial considerations. World-wide tendencies are sweeping scattered units into large compact masses; but Newfoundland is old, very old as colonies go, has been during its long life impervious to worldwide tendencies, and has been living its own life, in its own way, which is not the way of other states or colonies.

All the terrestrial matters

This chapter might be entitled Much Ado About Little, for Newfoundland from within only reveals a fraction of its discussed in nature. Its heart is on its outside; there its pulse beats, and this chapter have inAuenced Nerwfoundland but whatever is alive inside its exoskeleton is alive by accident. The sea clothes the island as with a garment, and that garment contains the vital principle and soul of the national little.

life of Newfoundland. With the Greeks, Ocean was a synonym for barrenness, land alone being lifegiving, and the thankless task of ploughing the sands between land and ocean brought but scanty profit to Faust himself. To the Newfoundlander the land is a forest or a 'barren', the ocean a mine or harvestfield, and on the foreshore the yield of the ocean is prepared for market. Briefly, this chapter is unreal and unilluminating because it has totally abstained, and probably it is the only chapter in any book on Newfoundland, which has totally abstained, from the word which heads the next chapter.

\section{AUthoRItIES}

\section{(1) Official.}

Reports from Governors and Correspondence with Governors, amongst which the following may be mentioned:

Sir J. Gaspard Le Marchant, Report, 1847-8, vol, xlvi, p. 24; Sir Antony Musgrave, Report, 1867-8, vol. xlviii, p. I2I (No. 3995); Sir Stephen J. Hill, Report, I872, vol, xlii, p. 344 (c. 617); Report, I873, vol. xlviii, p. 303 (c. 709 I); Sir John H. Glover, 1878-9, vol. 1, p. II (c. 2273); Sir Herbert Murray, 1896, vol. lvii, p. 627 (c. 8189); Sir William MacGregor, 1908, Report on Micmac Indians (cd. 4197). 
Other Papers of importance are :

Captain Granville G. Loch, R.N., Report to Vice-Admiral Earl Dundonald, upon the Fisheries of Newfoundland and Labrador, 1849, vol. $x x x v$, p. 493 (No. 327 ).

J. Canning, Report to the Government of Newfoundland, in Abstract of Reports on the Trade of Various Places, 1857, vol. xvi, p. 519 (No 2201).

Correspondence and Reports on Constitutional Changes in 1842 and $1854-5$; and on the Financial Crisis in 1895 .

Annual Statistical Tables relating to British Colonies, \&c.; and annual Statistical Abstracts are published by the Board of Trade.

\section{(2) Contemporary and Unofficial.}

L. A. Anspach, History of Newfoundland, 1819 .

Patrick Morris, Arguments to prove the policy of granting a Con-? stitutional Government (a pamphlet), 1828.

Newspaper Cuttings. consisting principally of Proclamations relating to Newfoundland, 1829-65, 7 vols. (Br. Museum Library 8I 55 ee 6).

Joseph Beete Jukes, Excursions in and about Nerefoundland, 1839-40,

2 vols., 1842 .

Sir Richard H. Bonnycastle, Nervfoundland in I 842,2 vols., I 842.

Nerefoundland Almanacs, of which the earliest in the British Museum

Library is by Ryan and Withers, 1844 ; and the latest is Yearbook and

Almanac of Newfoundland, 1909, published by Messrs. Withers.

Church in the Colonies, Diocese of Newfoundland, Journals of the Bishop's Visitations, 1845 et seq.

Patrick Morris, Short Review of the History of Nerufoundland, 1847.

Thomas Mullock (R. C. Bishop of Newfoundland), Two Lectures on

Newfoundland, 1860 .

Charles Pedley, History of Newfoundland, 1863.

Journal of the Royal Geographical Society; Julian Moreton, vol. xxxiv, p. 263, 1864; Alexander Murray, vol. xlvii, 1877, p. 267 ; Commander George Robinson, vol. xlvii, 1877, p. 278.

Alexander Murray and James P. Howley, Geological Survey of Nerufoundland, 1864-80, published 1881.

Michael F. Howley (R. C. Archbishop of Newfoundland), Ecclesiastical History of Newfoundland, i 888.

D. W. Prowse, History of Newfoundland, 1895, 2nd ed., 1896.

J. C. Millais, Nervfoundland and its Untrodden Ways (a sporting book), 1906. 


\section{CHAPTER IX}

\section{FI8H}

The chief NewroundLanders are men of one idea, and that idea pursuit is is fish. Their lives are devoted to the sea and its produce, cod-fshing, and their language mirrors their lives; thus the chief streets in their chief towns are named Water Street, guides are called pilots, and visits cruises. Conversely, land-words have sea meanings, and ' a planter', which meant in the eighteenth century a fishing settler as opposed to a fishing visitor, meant in the nineteenth century-when fishing visitors ceased to come from England-a shipowner or skipper. The very animals catch the infection, and dogs, cows, and bears eat fish. Fish manures the fields. Fish, too, is the mainspring of the history of Newfoundland, and split and dried fish, or what was called in the fifteenth century stock-fish, has always been its staple. And in Newfoundland fish means cod.

and cod- Newfoundland is as rich in coves, where cod-ships or boats curing; may shelter, as it is poor in beaches where cod can be split and dried, and their place is supplied by 'stages', or small wooden piers on wooden piles and with wooden roofs. The cod-fish are brought by boats to the piers, and are split and temporarily cured under the roofs upon the piers; as may be seen on the fiords of Norway. The final process of drying cod in the sun takes place in wooden erections called flakes, which resemble the pergole of southern Europe, but on whose roof instead of roses the hardly less odorous dead and split cod basks. A few years before this period began, most streets were flakes, beneath whose shadows young men and women walked,

Whispering murmurs of love at even.

Sir Richard Keats purged the north shore of St. John's Harbour, but sixty years ago the south shore of St. John's 
was still decorated with flakes, and even to-day flakes still lend their peculiar poetry and fragrance to Quidi Vidi and the smaller out-ports. Cod-fish, alive or dead, wet or dry, have exercised an all-pervading influence over the destiny of Newfoundland.

Until lately ${ }^{1}$ cod-fish were never caught in winter, but the which only whole 'unsown harvest of the sea' was reaped and gathered sumpy in between May and October. If, then, all Newfoundlanders and therewere codders, why should not they learn a lesson from the foreformercod, and absent themselves from an island where they were an annual not wanted for six months in the year? This was the un-passingand answerable question which was asked again and again by of the advocates of the old English policy, which encouraged Atlantic; a fishing-fleet to ply between Newfoundland and England every year. Again, if residents never did anything seriously except fish for cod, were they not like fish out of water in winter? Might they not become idlers, drinkers, or paupers? At all events, they would be happier and better employed in England. This view was at the bottom of the old policy which discouraged residents. The political ideal of keeping England provided with hosts of men and ocean sailors, and with wooden walls, like those which repelled the Spanish Armada, only reinforced a position which was after all founded upon a study of man and cod.

But common sense replied to these arguments of common but also sense by arguments which were conclusive as far as they went, ruggested although they did not go far.

caretakers;

Ever since Cabot and his successors caught cod by letting neverthedown hampers from their decks into the sea, all cod, including fess codthose that were caught on the high seas, were caught in rowing-little more boats. It would be the height of absurdity to bring the same than halfboats from England or to build new boats in Newfoundland each year, but boats could not be left in the island without some one to mind and mend them. Ever since the time of Guy

$$
1 \text { Post, p. } 213
$$

VOL. V. PT, IV 
residents have minded and mended boats. Similarly, in the principal harbours, except in Placentia and a very few other favoured places, 'Nature has denied (the principal harbours) favourable beaches for drying the fish, and thus expensive establishments of curing houses, stages, and ways have to be kept up,' ${ }^{\prime}$ or, as in old time, to be created and destroyed every year. Resident caretakers were required for flakes and stages as well as for boats, in order to prevent waste, and those fared best who recognized this necessity. But caretaking could scarcely be described as work, and the idleness of winter became the curse, just as the energy of summer became the blessing, which Providence, impersonated by the cod, bestowed upon the country; and the only reason why idleness did not lead to starvation was because the capitalist came to the rescue and persuaded the residents to rely during winter on credit for their daily bread. The remedy had its drawbacks, but the only alternative remedies were pauper relief, which would have been worse, or thrift, which was not available. The cod made its pursuers half-timers; and palliatives, but not cures, for periodic unemployment were furnished by resident caretakers, and by capitalism on an inchoate and tentative scale. In spite of these palliatives, winter pauperism was the baneful influence with which the cod afflicted its devotees, and in the Sixties it happened once that one-fourth of the entire public revenue was spent on pauper relief. ${ }^{2}$ The conditions of the cod-fishery indirectly modified the evils which it directly created; but these evils were only removable by things which had nothing to do with cod-fish. Antidotes were furnished in the early history of the colony by trapping and boat-building, then by seal and salmon, and in this century partly by the incipient land industries which were discussed in the last chapter, but mainly by subsidiary marine industries, which have already attained considerable im-

'Bonnycastle, op. cit., vol. ii, p. I68.

2 Accounts and Papers, 1866, vol, xlix, p. 399, No. 3719 I. 
portance. Seals, salmon, herring, lobsters, and whales began to counteract the bad example set by the cod, for the horoscope of the island was evidently cast in the constellation Pisces, with Gadus Morrhua as its presiding but not its only star.

Ever since Guy settled by Port de Grave the stars in their until boat. courses fought for boats and against ships. The anti-settlers ing and were right. Boat-fishery was destined to supplant the ship-proved fishery. The cod hugged the shore, therefore the codders more effechugged the shore, and boats which were at first auxiliary to cod-fishery, ships superseded ships, or ships became auxiliary to boats. Ships were usually useless without boats, and boats were usually useful without ships; consequently the law of the survival of the fittest made ships almost disappear from the cod-fishery of Newfoundland. An effect was produced both on England and on Newfoundland.

English fishing-ships ceased to vibrate between England and men and Newfoundland like the pendulum of a clock. 'Suppose,' grew tired it was said, ' my workshop and tools are twelve miles away, and fro for and I can only work for half a day; it may be good for my the sake of legs to walk backwards and forwards to my work every day, and to and legs are serviceable in war; but is it likely that I should Make the do so, if wagons and tramcars are continually going to and strong; fro, or if good houses are to be had near my work?' The circumstances of the Newfoundland fisheries were similar. The fishing-ships that crossed the Atlantic during the seventeenth century were gradually transformed during the eighteenth century into passenger ships; and the habit of living at the workshop grew more and more. Consequently West of England fishermen and ocean-going fishing-ships ceased during this period to play a part in the Newfoundland fisheries, and the whole dream of raising up a nation of oceanic sailors, by training them in catching cod-fish in a hemisphere not their own, was dispelled, or rather fulfilled in another way. 
in spite of It is one of the paradoxes of history that the total which more and more British

ships went to Neredisappearance of the British fishing-fleet from the waters of Newfoundland increased the number of British ocean-going ships connected with the fishery. According to theorists their foundland, number should have been halved; but in practice it was 1836 et seq., tripled. In the middle of last century a second but less startling historical paradox occurred. The relaxation and repeal of the Navigation Laws confining colonial trade to British ships was accomplished in 1849 , and instead of diminishing added to the number of British ships trading with and New - the colony. A third paradox occurred in 1900, when Newfoundlanders began to strengthen the Navy, roco, foundland fishermen were drafted into the Naval Reserve for the first time. For two centuries and a half Newfoundland was regarded as a prime source of naval strength; but it was nearly a century after this theory was abandoned that Newfoundlanders began to contribute sailors to the Royal Navy. In the following table, which illustrates these two first paradoxes, three periods have been taken fifty years apart: the first period is the last peaceful period of five years during which British fishing-ships came to Newfoundland; the second period is the last period before the Forties when the Navigation Laws petered out; and the third period illustrates a typical modern lustre.

Averages.

$1786-1790 \quad 1836-40 \quad 1886-90 \quad 1906$

British ships cleared inwards in Newfoundland.

$\begin{array}{lrrr}5^{14} & 850 & 144^{2} & { }^{1} 5^{83} \\ 3^{2} & 53 & 91 & 100\end{array}$

Ratio of Progress and began Newfoundlanders began to rely exclusively on boats for
tobuild and their principal fishery; yet by another paradox the colonial tobuild and their principal fishery; yet by another paradox the colonial the Banks, fishing-ships increased. The fishery of Newfoundland became a shore-fishery, and nothing else, because a shore-fishery 
involved 'less expenditure and more success' $;{ }^{1}$ and Sir W. Whiteway stated to the Halifax Commission in 1877 that 99 per cent. of the fishery of Newfoundland was carried on within the three-mile limit. ${ }^{2}$ Bounties were granted to ships from the United Kingdom which fished on the Grand Banks from I 775 to I802; after which English and Colonial ships visited the Banks on equal terms until the close of the Napoleonic wars. After the peace ${ }^{3}$ the Grand Banks were deserted by British ships, both from England and from Newfoundland. John Macgregor (1828), Sir Richard Bonnycastle (1841), Hon. Patrick Morris (1847), Sir J. Gaspard Le Marchant (1848), Bishop Mullock (I86I), and Sir Stephen Hill (1873) noted the fact, and Morris wrote with Irish exaggeration that 'Thousands' (meaning hundreds) ' of ships belonging to the French and the Americans are engaged on the deep sea fishery. There is not one British ship fitted out for the Bank fishery.' ${ }^{4}$ Two popular explanations held the field. Shortly after 1818 large bounties and privileges were offered by France, by the United States, and for a short time by Spain, but no bounties were offered by Newfoundland to the bankers. In consequence of these bounties Frenchmen went to the Grand Banks with ships of 150 to 300 tons, and with bultows in 1820 , and Gloucester (Massachusetts) sent forth its Captains Courageous and became the fish capital of the United States in 1825 . In 1876 similar bounties were offered by Newfoundland with such success that in 1879 Sir J. Glover wrote that 'the codfishery in the Banks, which was extensively prosecuted in former times, has recently been revived'; and in 1892 there were 330 , in 1908 there were 107 Newfoundland ships upon the Banks, and bank-fish are now 7 or 8 per cent. of the total catch. But trade is rarely so responsive to the puppet-strings

1 Bonnycastle, op. cit., vol. ii, p. I6r.

2 Accounts and Papers, I878, vol. $1 \times x x$ (c. 2056), p. 284.

3 Nervfoundland Blue Book, I828, gives Io Bankers, although MacGregor (1828) says there were none.

1 P. Morris, Short Review of the History of Newfoundland, 1847, pp. $\mathrm{v}$ and 35 . 
as to die or dance at the caprice of the protectionist behind the stage; and it was pointed out that the Frenchmen and Americans, who almost monopolized the Banks since Waterloo, sailed in ships of larger burden than those of Newfoundland, and used new fishing implements called 'bultows' which often contained 5,000-6,000 fathoms, or six or seven miles of line, to which hooks and weights were attached at certain distances in order to sink them in the sea. ${ }^{1}$ The bultow was unknown in Newfoundland, and inspired a terror which is always associated with the unknown. Newfoundlanders dared not compete with it, and feared that if they did their hooks and lines would be caught in its monstrous folds and destroyed. They were deterred by the same motives as those which kept aboriginal archers away from hunting-grounds frequented by riflemen. Further, their skippers, though incomparable coasters, were bad bankers, because they relied only on dead reckonings. $^{2}$ Moreover, their ships, which were not so large as those used on the Grand Banks by Englishmen in the eighteenth century and by Frenchmen and Americans in the nineteenth century, were being used elsewhere where their size was more appropriate and where no competitors intruded.

In 1793 or thereabouts colonial sealing-ships were introduced for the first time. Sealing had hitherto been practised with nets and boats in winter along the shore, and depended for its success on the continued prevalence of north-east gales; for the bay-seal is of little account in commerce, and the harp-seals, hooded seals, and square flippers, which are always of great value in the markets of the world, have their homes and bring forth their young upon ice floes, which descend from the far north, hugging the coasts of Labrador, and afterwards drifting out into the open sea, unless perchance they are blown into the bays of

1 Captain Loch, in Accounts and Papers, 1849, vol. xxxv, p. 493, No. 327, p. 3.

2 Report of Fisheries Commission of Nerufoundland, 1890. 
eastern Newfoundland. Ever since $1793^{1}$ the sailors of Newfoundland might be seen every March driving their ships in amongst the ice-floes, leaping out on to the ice, and doing infant seals, some three weeks old, to death, by thousands at a time, while basking in the sun. The trade was less exposed to chance, although men's lives were more exposed to risk. Danger added zest to the pursuit, and a boy who had once been through it was no longer a boy but a man. He had won his spurs, so to speak. It was partly, to meet this demand for sealers, and partly too to exploit the Grand Banks, which had hitherto been exploited by ships which came from the old country, that the ships of 1804 were built. $^{2}$ Sealing and banking were just compatible; for sealing began at the end of February and ended in May, and is now limited by law to begin on March ro and to end with the end of the first trip and before May. May, however, was somewhat late for the Banks; bait had to be caught, and there were places nearer home where bait might be caught, and fish might be caught and cured. The war had broken out, and the French had deserted the Treaty shore. So after sealing, men took their ships thither in June. Banking suffered because the northern fisheries were more compatible than banking with sealing. Peace returned in 1815 , and with it the French returned to the Treaty shore. The Newfoundlanders, loath to change their habits, went a little further north with their ships from June to October; and the scene of the sequel to sealing was shifted to Labrador.

The ship-fishery off eastern Labrador was a substitute for and for the the ship-fishery on the Treaty shore and on the Banks, and Lahrador its history was a repetition of the history of Newfoundland in miniature. The peace of 1763 created it, and the peace of I 8 I 5 tripled it. In 1828 the only Colonial sea-going ships

1 See J. Bland's letter cited by Prowse, pp. 419, 420; Sir G. Le Marchant's Report, I 847-8, vol. xlvi, p. 24 , No. I005.

2 Ante, p. 176. 
were seal-going ships and Labrador fishing-ships; and the latter included the former and were 200 or 300 in number, ${ }^{1}$ sailing from Carbonear, ${ }^{2}$ which was to Labrador what Dartmouth was to Newfoundland in the preceding centuries. In the Forties 90- to 100-ton sealing-vessels, which were built in Nova Scotia and Prince Edward Island, were preferred; consequently the ships of the Forties, which exactly corresponded in size to the ocean-going West-English ships of one or two centuries ago, were built primarily for the fishery in Labrador. In 1863 steel-sheathed steam-sealers, which it was impossible to build in Newfoundland, began to replace the old sailing sealers, and the old-fashioned home-made article seemed doomed, when a return to the Banks found a new use for it and created a demand for more. The shipping of Newfoundland now (1900) numbers 3,355 vessels, averaging 43 tons, and is largely employed on the Banks and in Labrador.

Labracior being to Nerefoundland what Nervfoundland was once to the West of England,
The 40-ton ships which came and went, the boat-keepers who remained behind, and the absence of law and government in Labrador, recalled incidents in the history of the colony which colonized it. During this period Labrador always had magistrates, but not always resident magistrates, ${ }^{3}$ and, until $186_{3}$, Courts (1 $\left.826-34\right)$, Customs officers $(\mathrm{I} 84 \mathrm{I}-5),{ }^{4}$ and fishery superintendents $(\mathrm{I} 856-7)^{5}$ were more rarely seen than bishops, and almost as rarely seen as Governors; and even since 1863 , although they had officials, the people of Labrador never had representative government in any shape or form, nor did they become part of any electoral district, which seems to be the only administrative unit of which Newfoundlanders make use. The inhabitants

1 John MacGregor, British America, 1828, vol. i, p. 207.

2 E. Gosse, Life of $P$. H. Gosse, 189o, pp. 47, 49.

3 Ante, p. 154.

4 Sir A. Bannermann, Dispatch, Aug. 10, 1863, in Accounts and Papers, 1864, vol. xl, p. 54I, No. 159; and Newfoundland Almanack for 1845 (1 844$)$.

5 J. L. Prendergast. 
were those who had been left behind upon the shore like driftwood or seaweed by the receding tide of summer fishermen, and represented Jersey, especially near the frontier of Quebec Province, ${ }^{1}$ Poole, London, ${ }^{2}$ and Torquay, ${ }^{3}$ as well as Conception Bay and Twillingate. In 1826 the northern limit of the summer fishery was Indian Harbour, near Sandwich Bay, ${ }^{4}$; in 1848 Cape Webeck, ${ }^{5}$ north of Hamilton Inlet; in 1883 , thanks to steamers, it was Nachvak, ${ }^{6}$ and in I892 Cape Chudleigh, at the mouth of Hudson Strait. The inhabitants, who are few in comparison to the vagrants, number about 4,000, and are very scattered and mostly males. Primitive hospitals established by the Deep Sea Mission at Indian and Battle Harbours connect the settlers with one another in time of trouble and with Newfoundland, in the north of which St. Anthony is the mission centre. Land, which consists of 'rocks of every conceivable variety of shape and outline, but all without exception presenting no shapes of life or vegetation beyond a rough spongy moss, with occasionally low berry-bearing shrubs', 8 does not attract women, as Pastor Brand discovered, and in 1848 there was only one white woman between Battle Harbour ${ }^{9}$ and Sandwich Bay, which was then the northernmost settlement. ${ }^{10}$ But the statistics, except of the cod-fishery, are not trustworthy; for how could a census be taken except in an electoral district? and the figures of the cod-fishery bring back reminiscences of old Newfoundland with a vividness which is almost uncanny. Thus the first accurate statistics of the seventeenth century put the yield of Newfoundland cod in one year $(1677)$ at 221,000 quintals, and

1 e. g. De Quetteville and Boulettier.

2 e.g. Hunt and Henley. $\quad 3$ e. g. Stabb.

4 Sir W. MacGregor, Reports on ... Labrador, I905-8, p. I 28. Lat. $54^{\circ}$ c. ${ }^{5}$ Lat. $55^{\circ}$ c. See Church in the Colonies, No. 21, p. 67.

6 Lat. $59^{\circ} \mathrm{c}$.

7 Lat. $60 \frac{1}{2}^{\circ} \mathrm{C}$.

8 Church in the Colonies, No. 30, p. 38, and No. 19, passim.

9 Lat. $52 \frac{1}{4}^{\circ} \mathrm{C}$. 10 Lat. $53 \frac{3}{4}^{\circ} \mathrm{c}$. 
the first accurate statistics of the nineteenth century put the average annual yield of Labrador cod in $1889-90$ at 227,000 quintals. It seems as though history were repeating itself, not only in its methods but in its results; and that the east coast of Labrador to-day is a replica of the east coast of its parent-colony two centuries ago.

except for its Indians and Es. kimos,

But the civilization of Labrador contains three elements which were never present in Newfoundland-trading natives, Moravian missionaries, and the Hudson Bay Company. The presence of the Moravians was due to Eskimo sealers and whalers on the seashore. The Hudson Bay Company used in former times to settle near some river-mouth and to deal almost exclusively with inland Indians, whom they left undisturbed in the interior, and to avoid if possible the Eskimos; but in the nineteenth century they abandoned their conservatism, explored the interior themselves, and associated more than they had been accustomed to associate with the Eskimos. Both the Moravians and the Hudson Bay Company were traders who aimed at a trade monopoly ; and both dealt with, or worked through, native producers, which the Newfoundlanders never did.

with whom In the Thirties the southernmost Moravian settlement the Hudson Bay Company and Moravians dealt respectively. was still at Hopedale, ${ }^{1}$ a few miles north of Cape Webeck, and its northernmost had advanced a few miles beyond Okkak to Hebron ${ }^{2}(1830)$. The Hudson Bay Company, hearing that the Moravians intended a further advance into Ungava Bay in Hudson Strait, sent Dr. Hendry from James Bay to Richmond Gulf, and thence overland to Ungava Bay ( 1827 ), where they built Fort Chimmo on Koksoak River, thirty miles from its mouth, and from which they sent $\left(183^{8-42}\right)$ overland parties to a fort, which they had already built $(1837)$ on Hamilton Inlet near the Atlantic Coast. ${ }^{3}$ They crossed behind the backs of the Moravians from north to south, and

$$
{ }^{1} \text { Lat. } 55^{\circ} 3^{\prime} . \quad{ }^{2} \text { Lat. } 58^{\circ} \mathrm{I}^{\prime} . \quad{ }^{3} \text { Lat. } 54^{10} \stackrel{\mathrm{C}}{ }^{\prime} \text {. }
$$


Hamilton Inlet is also south of Cape Webeck, which was soon afterwards the northern limit of the Newfoundlanders. Fort Chimmo was situated 'amid moss-covered rocks, without vegetation and without verdure... as complete a picture of desolation as can be imagined ', ${ }^{1}$ and the overland routes from Fort Chimmo to the south-west and southeast were equally barren; but North-west House and Rigoulette, as the factories on Hamilton Inlet were called, proved serviceable dépôts for the Indian furriers of the interior. There, and more recently at Nachvak, Davis Inlet, Cartwright, and elsewhere, the Company overlapped the Moravians from the north, and the Newfoundlanders overlapped the Company from the south; and the three streams of tendency interlaced and passed into one another's boundaries without mingling, for they represented different cults and quests. The Company were after the Indians, and the Indians were after land-mammals; the Moravians were after the Eskimos, and the Eskimos were after sea-mammals; and the Newfoundlanders were after cod, or, if they settled, after cod, herring, salmon, and seals, which they caught with seines. Each stream represented a distinct type, and nowadays each of the three streams, except the Moravian stream, has overflowed the whole east coast of Labrador and remains distinct. The Moravians still keep to the north of Cape Webeck, occupying Makkovik(1 899), Hopedale, Nain, Okkak, Hebron, Rama (1871), and more recently Port Burwell at Cape Chudleigh, and controlling 1,200 to 1,300 Eskimos and half-breeds.

The ship-fisheries were now conducted from a base in The merNewfoundland instead of from a base in Europe as in old chant still times; nevertheless, they still retained the mediaeval charac- ship-fisherteristics which they presented in the sixteenth, seventeenth, ies, because and eighteenth centuries. No wages were paid, but the market is

${ }^{1}$ John Maclean, Twenty Years' Service in the Hudson Bay Territory, 1849 , vol. ii, p. 75 . 
zoorld-zvide crew took one-half, and the shipowner or 'planter' took (amongst other the other half, of the proceeds of the voyage. But outfit, reasons), tackle, and food for the voyagers and their families were required, and these things were supplied by a mortgagee on the security of the proceeds of the voyage. As the loan was usually equal in value to one-third of the estimated proceeds, the old fishing system, though nominally a halfand-half system, was in reality a system of thirds, the planter taking one-third, the crew a second third, and the mortgagee $a_{\text {e }}$ third third. There have been from time to time variations of this scheme, as, for instance, when the mortgagee owned the ship and the 'planter' was merely skipper, or when steamers were introduced. Steamers required more capital, squeezed out the owner-planter, and obtained larger and more secure results; consequently the proceeds of the fishery were divided into four parts instead of three parts, and the shipowners and mortgagees absorbed three-fourths instead of two-thirds. The metayer system persisted through all these changes, and beneath every disguise. From 1497 to I910, the absence of a wage-earning class, which was the characteristic of the ship-fishery, made the presence of a mortgagee indispensable; but the mortgagee did not make his advances in money, nor was he repaid in money, for neither he, nor the planter, nor the crew wanted money, and the system dates from a period before the age of money. What the crew wanted most was food and clothes for their wives and children, and what the skipper wanted most was food and tackle for his ship; and food, clothes, and tackle were imported. Consequently the mortgagee was an importer. Again, the mortgagee was never repaid in money but in seals and cod, a currency which would have been useless to him if he had not been an exporter. For the markets where the seal and cod were bartered or converted into money were outside Newfoundland, and Newfoundland, being a country where every one produced the same things, had no in- 
ternal market. Three or four centuries ago the Mediterranean was the chief customer for cod. In recent times Gibraltar has become an important Mediterranean port, and Brazil equals Portugal in its appetite for this Lenten fare, but otherwise there has been no change. The following are the figures for I 87 I and I906, both of which were typical years :

\section{Percentage of Cod and Cod-oil exported to}

Ratio in $187 \mathrm{I} \quad$ Ratio in 1906

$\begin{array}{lcr}\text { Mediterranean } & 43 & 53 \\ \text { Brazil } & 26 & 23 \\ \text { Canada } & 4 \frac{1}{2} & 9 \\ \text { West Indies } & 9 & 6 \\ \text { United Kingdom } & 15 & 5 \\ \text { United States } & 2 \frac{1}{2} & 3\end{array}$

That is to say, Canada, the United States, and England, which fed and clothed Newfoundland, took only 17 per cent. of its cod, and the rest of its cod went to countries which sent it little or nothing. What commerce there was in Newfoundland was circuitous and worldwide, and its capitalists were compelled to be members of the world-market. Their business domicile was usually in England, and the Newfoundland merchants who petitioned in 1838 against mob-law included merchants from Poole (54), Bristol (29), Liverpool (19), and Torquay (9), as well as from Conception Bay (79), and the same man often made his presence felt at the same time in Poole and in Harbour Grace, and 'bestrode the narrow world like a Colossus'. He united the functions of moneylender with those of wholesale merchant, and was universal provider of the necessaries of life and universal buyer of what the shipowners and ships-crews sold him.

Similar causes produced similar results in the shore fisheries. and in the The fishermen were not hirelings, but owned a house, a potato- boat-fisherpatch, a boat, and everything which they produced; and were differmore like peasant proprietors than any other class of people ences) 
in the British Empire. They, too, depended on the capitalist, who imported and lent what they required, and who bought and exported what they produced. Sometimes he lent them clothes, food, and tackle in return for one-half of their catch, and sometimes he made fixed monthly or annual payments in kind for the whole of their catch. His loans were never wages, but the price which he paid for half or all of their fish, which thenceforth belonged to him. ${ }^{1}$ It is true that the boatmen often lent themselves out to one another, but they were rarely if ever the hirelings of the merchant.

(integration of capital being appropriate to hoth).

The essence both of the ship-fishing and of the boat-fishing system was that numerous independent producers of one article, which was exported, wanted three articles, which were imported. By taking the one exported article in unlimited quantities, and by giving in return the three imported articles in quantities only limited by the demand, the merchant endowed the one article with general purchasing power, and made it perform the functions of a currency. He acted as bank, mint, and clearing-house, besides acting as moneylender, export-agent, and import-agent. He combined six or more functions of capital, and represented the integration of capital. A disintegrating element set in when banks and brokers were interposed between the producer and those to whom he sold and from whom he bought. But banks presuppose coin, and even to-day banks are recent, and solvent banks still more recent; coin was a little less than $£$ roo, 000 in $187_{2}$, and is a little more than $£_{200,000}$ now, and the cash nexus has only been imperfectly established.

Therefore The peculiar relation between independent local fishermen, Nerwfound- shipowners, and worldwide merchants still permeates New-
land is sui generis and foundland, and makes it ill-adapted to industries which arise unchang. ing, spontaneously elsewhere. Cod-catching, like gold-digging, unfits a nation for any pursuit other than the pursuit to which

1 Captain Loch's Report, 1848, in Accounts and Papers, 1849, vol. xxxv, p. 493, No. 327 . 
it owes its being. The framework of society is fishy and inelastic, and the difficulty, which Newfoundlanders experience in abandoning the sea, is due to their archaic social institutions as well as to their inherited and natural proclivities. Their political unchangeableness reflects the stereotyped monotony of their social and industrial life. The backwardness of New. foundlanders in turning to the land is also accounted for by new fishing developments, which have from time to time attracted, diverted, and absorbed the spare energies of men, whom three or four centuries of continuous practice have made the most expert fishermen in the world.

In fashioning the political, economic, or social history of just as cod, Newfoundland the cod has been almost omnipotent, and has cod-fishing set its image and superscription upon every institution. The trading, whole country seems cod-created, and the cod-banks have proved more inexhaustible than any fields of gold and moun- of its being, tains of silver. One nation-State, three savage nations, half changing. a dozen genera of mammals and of birds, and a dozen dynasties have become extinct while the much-persecuted cod-fish of Newfoundland has shown no appreciable change in its numbers, habits, and favourite places. Indeed, there is something romantic in the immutability of the cod. Even after death it goes in almost the same quantities, almost to the same countries, as of yore. It is sublimely indifferent to man, and its indifference is due to the fact that one cod's roe contains nine million eggs, so that four or five cod's roes could easily supply all the cod ever exported in one year from Newfoundland. During the past century, when the utmost skill and energy have been applied to its capture, it has increased instead of diminishing; but in reading the following tables it must be observed that Labrador is not included before $\mathbf{I} 886$, and that Bank fish were not caught between I $82 \mathrm{I}$ and 1877 , so that the figures indicate permanence rather than progress. Nor do the figures mean that each year is exactly like the last. Quantities have varied from time to time, but 
not so much as prices; thus in the last seventeen years the lowest average price was ros. $2 \frac{1}{2} d$., and the highest average price was $\AA_{I}$ Is. Iod. a quintal, ${ }^{1}$ and by an odd coincidence the lowest price was current when the export was least (I897), and the highest price when the export was most (1906).

\section{Quintals of AnNual Exports of Cod $\times 1000$}

\begin{tabular}{|c|c|c|c|c|c|}
\hline . & $1811-20$ & $182 I-50$ & I $851-90$ & I 89I-1906 & $1907-8$ \\
\hline Minimum catch & 711 & 726 & 688 & 947 & \\
\hline Ium catch & 1086 & 1175 & I $39^{2}$ & $148 \mathrm{I}$ & \\
\hline Aver & $92 \mathrm{I}$ & 875 & 1016 & I 331 & I 509 \\
\hline
\end{tabular}

N.B. - Where returns are wanting, e.g. in 1818 and 1892 , and in several years between 1821 and 1840 , decennial averages have been taken from available returns.

AuthoRities

See end of Chapters VIII and X.

1 Comp. ante, p. 155. 


\section{CHAPTER $\mathrm{X}$}

\section{BAIT-FISH-EXPANSION-AND CONFLICT}

THE central object in an allegorical picture which symbol- Cod and ized Newfoundland would be the cod-fish, and around it would determined be grouped its favourite bait the herring, the capelin, which the history resembles a sardine or anchovy, and the squid, which is a kind of Norundland, of cuttle-fish. Shoals of herring strike into shore in the middle of May and in September. In the middle of June capelin sparkle like foam upon every wave which breaks upon the shores, where they are gathered by women and children in buckets'-full, and in August shoals of squid supply their place. These are the cod-baits of Newfoundland; and as in Newfoundland cod is supreme and fish means cod-herring, capelin, and squid, whether used as bait or for their own sake, are spoken of as the bait-fish of Newfoundland.

Cod brought men into Newfoundland, and its influence on bait-fish population in the nineteenth century produced, or helped to producing produce a trek into Labrador after cod, herring, and seals; plications, conversely where there were no cod, settlers were absent, and Chappell wrote in 1818 that Ingornachoix Bay, though teeming with lobsters, was without cod, and therefore without men, and Sir W. Kennedy wrote in $\mathbf{1} 885$ that Hare Bay was also without men because it was without cod. In the fishing treaties with France in $\mathbf{1} 78_{3}$, and with the United States in 1818 , cod was the one kind of fish of which the treaty-making powers thought, and the treaties were made in the interests of the codders. Yet the principal movements of population, and all the international complications of this period were due not to the cod but to the satellites of the cod, and more especially to its chief satellite, the herring. As in these latter times the seal assistseal allied itself to the cod in bringing material prosperity and ingcod, and political peace, so the lobster allied itself to the herring in assisting 
bringing material prosperity and political strife to the colony. The cod and the seal have been its guardian angels, while the herring and lobster have been the authors of all mischief, and yet all four influences whether beneficent or malignant, and whether principal or accessory, made for progress. The immediate effect produced by these spirits of the sea has been to drive men into new haunts or homes, and their ultimate effect has been to make or mar treaties between England, France, and the United States.

People were While the people of the east coast satisfied their restless impelled by impulses by annual tours to the north, the southerners steadily
both inboth influences, westward along the south coast went westward and went to stay, or to go still further and stay. The east-coast process resembled a series of leaps and bounds, the south and west-coast process resembled the stretching of elastic. The former flew, the latter flowed.

-especially In 1818 Burin was but little known; in $183^{2}$ it became the by illegal bait-sales at St.

Pierre, 1818 et seq. -which raised political storms, capital of an electoral district which was created at the foot of the promontory between Placentia Bay and Fortune Bay, and in $184 \mathrm{I}$ its shipping was four times as much as that of Placentia. The new influence which made men drift westward, against the stream and with the sun, was St. Pierre, which was now the baiting-place of the big bounty-fed Bankers of old France. The old French capital was being eclipsed by the new French capital. In 1854,296 French Bankers made St. Pierre their rendezvous, and bought from the boatmen of Burin and Fortune Bay $f_{5} 6,000$ worth of herring and capelin. Jukes (1839), Loch (1848), and Canning (1854), denounced the anti-patriotism of the sellers; bait-sales to foreigners were forbidden by English Acts which were unrepealed though forgotten ${ }^{1}$; and export duties on bait were imposed by a local Act of 1836 , which no one enforced. Denunciations, prohibitions, and penalties were words, idle words; but a market where $£_{56,000}$ a year could be won

126 Geo. III, c. 26, s. I4, repealed Statute Law Revision Act, 187 I. Compare Io and II Will. III, c. 25 , s. I. 
was a living magnetic force. Accordingly in 1854 Governor Ker Baillie Hamilton, backed by his Solicitor-General, introduced a Bill which would have effectually prevented bait-sales to foreigners. Hardly had he done so when a magician which were appeared upon the scenes and muttered a formula. There allayed by was a sudden revulsion of sentiment. Things which had procal codbeen blamed as secret vices were praised as public virtues, fishing $_{\text {santioned }}$ and even the ineffective law of $183^{6}$ was repealed. The ${ }^{b y}$ the magician was the United States, the conjurer who raised him Wreaties of was Canada, the formula was a Treaty, and the word in the ton, 1856 , Treaty which stilled the storm was the word cod. Negotiations with the United States for the purpose of explaining and expanding the Treaty of 1818 had been suggested by Canada in 1847 , and resulted in the Treaty of Washington, which was concluded by the Earl of Elgin on behalf of British North America in $1854 .^{1}$ It was terminable after ten years, and during its continuance Americans were admitted within the three-mile limit of the British coasts of the Atlantic and the Gulf of St. Lawrence, for purposes of sea-fishing, and to the same shores for the purposes of curing and drying fish (but not so as to interfere with private property or British occupants), and British North Americans were admitted to analogous privileges on the seas and shores of New England. ${ }^{2}$ A postscript to the Treaty admitted fish and fish-oil free from the country of one into the country of another of the contracting parties. To the Newfoundlander fish meant cod, codfishing necessitated bait-buying, and cod put bait-bills out of the minds of Newfoundlanders for the twelve years during which the Treaty lasted. In 1866 the United States dissolved the Treaty, and immediately bait-fish began to loom once more before men's minds and to portend a political storm; but the storm was postponed by the issue of licences to buy or sell bait, and was allayed by the second Treaty of

1 Accounts and Papers, 1854-5, vol. 1v, p. 367, No. I86r.

2 N. of lat. $36^{\circ}$. 
Washington, in $187 \mathrm{I}$, which resembled the Treaty of 1854 , except that it curtailed the right of fishing on the shores of New England. ${ }^{1}$ Its lists of free imports included sea-fish and fish-oil but excluded other articles, and a Commission was authorized to assess the difference in value between the privileges accorded to the United States, and those accorded

(the Halifax Commission, 1876 , arising out of the second Treaty).
This westzuard migration went on gradually to Cape

Ray, near which codfishing contimued during winter, to the British colonies by the Treaty. This Commission, which is known as the Halifax Commission, ${ }^{2}$ assessed the

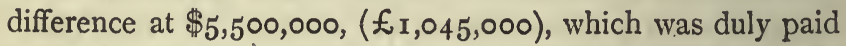
by the United States to England, and by England to Canada and Newfoundland; and the United States terminated the second Treaty in January, I886, in the same way as it had terminated the first Treaty. Long before its termination, indeed before the Halifax Commission began to sit, the character of the herring fishery had been changing, the political horizon was darkening, and this fish of evil omen was baulking the efforts after peace inspired by the cod. Before discussing these changes we must follow the further flow of people along the southern shore from east to west, and along the western shore from south to north, between 18 I 8 and 1857 .

These westward movements proceeded in silence without friction, like the movements of migrant birds or fish. The rush towards the new market from the east pushed those who were already there still further west, or else the newcomers passed through the full places into the empty places which were beyond. No one went inland; and the human stream percolated every chink and cranny of the coast. The Bay D'Espoir, which was the extreme western limit of the Electoral Districts, ${ }^{3}$ that is to say, of civilization between $183^{2}$ and 1854 , was reached and passed. In 1857 a missioner described the coast between Fortune Bay and Cape La Hune (forty miles west of Bay D'Espoir) as a 'coast of about I 50 miles

$1 \mathrm{~N}$. of lat. $39^{\circ}$ only.

2 Accounts and Papers, 1878, vol. lxxx (c. 2056), contains the Halifax Commission's Proceedings.

3 Bonne Bay (D'Espoir Bay). 
with forty settlements at intervals of three or four miles, consisting for the most part of four or five families each, in some instances of two or three, in a few of as many as eighteen or twenty. At Gaultois and Harbour Briton, besides the fishermen's families there was a merchant's establishment . . . of

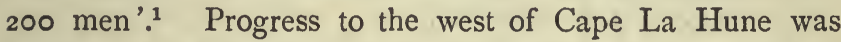
similar. At the beginning of the period, there were 'three or four families', and no more, between Cape La Hune and Cape Ray; in 1839, there were 'several inhabitants in almost every cove '. ${ }^{2}$ The very islets were filling to the brim. On Burgeo Islets there were 'two families' in 1834 , forty or fifty houses and a store in 1839, and 700 inhabitants and a merchant's establishment in 1848 . In 1838 Burnt Islets were empty, and in 1848 they had 100 inhabitants. ${ }^{2}$ In 1840 and 1848 there was a merchant's establishment at $\mathrm{La}$ Poile Bay ${ }^{3}$ kept by a Jerseyman, who had arrived there from some port further east; and in 1854 a new electoral district was created and was called Burgeo and La Poile District, because Burgeo Islets and La Poile Bay were the sites of the only mercantile establishments in those parts. Elsewhere men settled not in villages, townships, or homesteads, but by tiny family groups in sequestered nooks and creeks upon the coast or its islets. They all came to stay, and for the first time in history men fished for cod all the year round. ${ }^{4}$ Doubtless the north coast of Conception Bay was settled in the same way in the seventeenth century, but those old settlers came either from other settlements in Newfoundland, or from somewhere between Bristol and Exeter, and these latter-day settlers came either from Fortune Bay on their east, or else from Dorsetshire in England. The progress towards Cape Ray was as peaceful as it was spontaneous, and it had two effects upon the Treaty Powers. In 1840 Captain Milne

1 Church in the Colonies, 1857 , No. 35, p. 11.

2 Jukes, op. cit., vol. i, pp. 195-7; Captain Loch, ubi supra.

3 Anthoine (1840) and Nicolle (1848).

1 Captain Loch, ubi supra. 


\section{$2 I 4$ HISTORICAL GEOGRAPHY OF NEWFOUNDLAND}

heard of Frenchmen trespassing for bait on Burgeo Islets, and under the Treaty of 1818 Americans had curing and drying rights on unsettled parts of the south coast. Long before $185^{\circ}$ there was not a single unsettled landing-place on the south coast, so that French trespasses became impossible, and American rights obsolete.

and beyond On rounding Cape Rày we enter upon other scenes with Cape Ray other associations. St. George Bay dated from I 783 or
to St. George thereabouts, was a considerable centre of trade, and its Bay, where inhabitants numbered $75 \circ$ in 1848 , or, including the coast
the herring. fishery was between Port-à-Port and Cape Ray, 1,500 in 1856. ${ }^{1}$ Its paramount, principal fish was the herring, not the cod, and the principal market for the herring was neither Europe nor Brazil, but the Maritime Provinces, whither twenty-nine schooners used, in 1856 , to sail thrice every year. The close connexion of the West Coast of Newfoundland with the Maritime Provinces was then, and is still its distinguishing characteristic. In the Forties the herring industry of St. George Bay was proverbial for its brevity, for the herring were caught mostly in nets in two weeks of May, and the fishermen had little to do in winter except to make staves and ships, and to catch eels, which, unlike the herring, were perennial.2 Every creek between Port-à-Port Bay and Cape Ray had its family or two; in summer, British fishermen joined them from Cape Breton Island, and French codders fished off Codroy Island and Red Island, where they built stages and flakes, and employed during their absence English caretakers, even as they had employed English caretakers on the east coast in to Bay of I614.3 Between Port-ì-Port and the Bay of Islands there Islands, where the herring fishery were few or no settlers; at the Bay of Islands there were six or eight families in 1839 , and twenty families in different creeks in 1848 , one family being from Burin and several began after 1854 ,

1 Canning, Report, in Accounts and Papers, 1857, vol. xvi, No. 2201.

2 Canning's Report, uli supra. No. 88 . 
from Dorsetshire. Before 1854 there was no herring-fishery at the Bay of Islands; and between it and Port-au-Choix inclusively there were only 320 inhabitants in $1849^{1}$ and 460 in $1854^{2}$ Of these places between the Bay of Islands and Port-au-Choix, something less than villages, and more than villas, Bonne Bay, Cow Cove with its families from St. George Bay, and Ingornachoix with its shipbuilders, were the most important; and as on the south coast, isolated families filled to Ingornain the interstices between the big bays. North of Port-au- choix, wherethere Choix, we hear of some Nova Scotian sailors and residents were shipin St. John Island netting seals and giving away innumerable lobsters in $1853 .^{1}$ Lobsters were not despised as in Island, Chappell's time, nor were they yet a staple export. Still where there further north, St. Barbe Bay or Anchor Point was the sters, $\mathbf{1}_{553}$, principal place, and 100 or 200 persons lived in its neigh- and St. bourhood in 1848 , including Mrs. Genge, 'the mother of Barbe, the settlement,' who came with her family in 1817 , and some alsoreached Dorsetshire immigrants who had recently arrived. ${ }^{3}$ St. Barbe by British from and its neighbourhood formed a neutral district into which the northsoutherners and westerners poured upwards from the south, and a counter-current of east-coast men, Jerseymen, Englishmen, and other residents of Labrador poured downwards from the north. Up and down the whole of the west coast Englishmen dwelt and Frenchmen wandered, for this was the Treaty coast. The south side of Belle Isle Strait was almost without settlers or wanderers.

On the north-east extremity of Newfoundland there was Like the a French base independent of St. Pierre, to which, however, British, it was second in importance. The principal fishing-rooms visitors to of the French were within a few miles of one another at the cast and Quirpon, Griguet, St. Lunaire, Havres des Brehats, St. differed Anthony, Cremaillère, Goose Cove, St. Julien, Croc, Cap from one

${ }_{1}$ Church in the Colonies, 1849, No. 25, p. 6r.

2 Canning's Report, ubi supra.

3 Church in the Colonies, 1848, No. 21 , p. 79 ; 1853 , No. 30, p. 16 ; I857, No. 35 , p. Ir. 
another, in Rouge, and Conche, and the chief of these was Croc. ${ }^{1}$

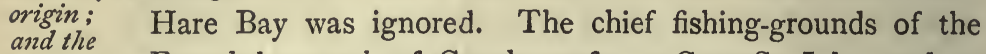
north-east French lay south of Conche as far as Cape St. John, and on Frenchbase this strand Englishmen dwelt by twenties in twenty-three
was Croc. coves in 1854 . St. Pierre was the gathering-place of the fishing-ships from Bayonne-which was the port of the Basque Provinces of France-and also from Dieppe, which is in Normandy and more rarely from St. Malo. Croc was the gathering place of the fishing-ships from St. Malo, St. Brieuc and Nantes, which are in Brittany, and also from Granville and Havre, which are in Normandy. The dividing line between Breton and Basque was not so distinct as it was once, but it was still discernible. The Bretons, as a rule, went straight from France to the north and the dwellers on the Basque coast went straight from France to the south of Newfoundland, as they did in the sixteenth and seventeenth centuries, the Breton sphere including the neighbourhood of St. Barbe. In the extreme north-east Englishmen were little more than caretakers for the French, and they came from a different neighbourhood, and represented different stocks and interests from those of the average westerner. Traders came not from Nova Scotia, but from St. John's and Harbour Grace; like Labrador, St. Anthony was peopled from Carbonear; and the oldest inhabitants at Quirpon of whom history makes mention arrived there in $1814 .{ }^{2}$ The Frenchmen on the north-east differed from the Frenchmen on the south-west; the Englishmen on the north-east differed from the Englishmen on the south-west; and the relation of Englishmen to Frenchmen was different on the north-east and south-west. On the whole of the west coast, the Englishmen were not only settlers but paramount. On the far north-east the French visitors overshadowed the English settlers. A trial of strength had taken place in $183^{\circ}$, when the Chamber of Commerce

1 Comp. ante, p. Ior note.

2 Church in the Colonies, I849, No. 25, p. 90. 
at St. John's sent a fishing-ship northward to Croc; but the ship was turned back even as Taverner's had been in I $729 .{ }^{1}$ Since 1830 Englishmen took the second place, and Frenchmen the first place in the north-east. And the disparity was enhanced by the annual presence of French cruisers in Croc.

In 1839 and onwards English cruisers patrolled the Treaty Inandafter shore of Newfoundland for the same reason as they still visit ${ }_{i s h}^{1839 \text { Brit- }}$ Patagonia from time to time in order to look after the waifs French and strays of our Colonial Empire. Ever since I839 the cruisers visits of one cruiser, or in later times of two cruisers, along the the Treaty western coast have been annual, and, when steam was shore conintroduced, Captain Cook's Port Saunders in Ingornachoix their Bay was the coaling dépôt. In 1848, while one English 2nationals, cruiser was employed, the French had two cruisers between an imporSt. Pierre and Port-au-Choix, two at Croc, one between ${ }_{\text {base, }}^{\text {tant }}$, Croc and Port-au-Choix and one between Croc and Cape St. John, which was the southern limit of the Treaty shore on the east coast. Croc was not only a fishing resort but a great French naval centre in the summer. It is not possible to exaggerate the serious position of affairs when English and French fleets met one another year after year, and claimed to exercise jurisdiction in the territorial waters and on the coasts of a thinly-peopled English colony. Moreover, irresponsible but serious disputants urged that the French claim was contrary to Treaties which made England sovereign over the entire island, and one of the provisions of the same Treaties was strained, to say the least, by English colonists.

The Treaty of Paris, I814, article I3, 'replaced' the French rights of fishery 'upon the footing in which it stood in the French I 792', in other words incorporated the Treaty of Versailles and the $(\mathrm{I} 783)$ and the Declaration of Versailles ( 1783$)$. The straining Treaty of Versailles defined the Treaty shore as extending Treaty from Cape Ray to Cape St. John, where the French were 
given the same right of fishery 'as they had the right to enjoy that which was assigned to them by the Treaty of Utrecht', and the English king was ' maintained in his right to' Newfoundland and its islets, except St. Pierre and Miquelon, 'as the whole were assured to him by the Treaty of Utrecht,' which enacted that 'Newfoundland with its adjacent islands shall belong of right wholly to Great Britain ... nor shall the most Christian King . . . claim the said island or islands or any part of it or them', and forbad 'subjects of France... to erect any buildings there besides stages made of boards and huts necessary and usual for drying of fish', but with power 'to catch fish and to dry them on land' along the Treaty shore. The Treaty of Utrecht, as revived by the Treaties of 1783 and 1814 , clearly established English sovereignty as sole and absolute; and clearly limited fish to things that were caught and dried during the summer. But the Declaration of Versailles $\left(\mathbf{I}_{7} \mathbf{8}_{3}\right)$ seems to have been also revived by and incorporated in the Treaty of 1814 ; and by the Declaration of Versailles the King of England promised to take 'measures for preventing his subjects from interrupting in any manner by their competition the fishery of the French during the temporary exercise of it which is granted to them upon the coasts ... of Newfoundland, but he will for this purpose cause the fixed settlements which shall be formed there to be removed'.' That is to say, if the French fishermen chose to fish in St. George Bay in large numbers, and could show that the English fishermen competed with them, the English fishermen would have to desist from fishing; and if the French fishermen could show that the fixed settlements in St. George Bay interrupted the French fishermen, every house would have to be pulled down, and every settler would have to go. The

1 The relevant parts of the Treaties and Declarations of $\mathrm{I} 7 \mathrm{I} 3, \mathrm{I} 7 \mathrm{6}_{3}$, 1783,1814 , and 1815 are given verbatim in Accounts and Papers, I 890-I, vol. xcvi (c. 6365), pp. I6, I7. The italics are my own. 
sword of Damocles hung over the settlement not only at St. George Bay but at the Bay of Islands, Bonne Bay, and St. Barbe. Or, to use a more homely metaphor, Englishmen lived in a glass house and dared not throw stones at the Frenchmen, when they sent round their fleet and exercised extra-territorial jurisdiction, as though the Treaty shore of Newfoundland were on a par with the Treaty Ports of China. The presence of their fleet was a violation of the Treaty of Utrecht; and the presence of English settlers on the Treaty shore might at any moment be proved to violate the Declaration of Versailles. Therefore England remained passive while a' French fleet usurped a fragment of its sovereignty, or treated the Treaty shore as though it were savage, or what diplomatists call unoccupied lands.

Oddly enough the Treaty shore resembled for a time and the savage lands far more than it resembled the integral part of fishermen a colony. It was without Government. The Almanack for in wohat 1857 refers to $\mathrm{H}$. H. Forest and E. Alexander as magistrates, their reand to H. H. Forest as Preventive Officer; and the Almanack naval for $\mathbf{1} 86_{3}$ refers to $\mathrm{J}$. Allery as Commissioner for issuing officers mesne process at St. George Bay. Otherwise there was neither judge, policeman, customs officer, nor any other officer or official on the shore until 1877 . The very same anarchy prevailed on the west, as that which had prevailed two centuries ago on the east of Newfoundland, and the very same remedy was applied. The naval officer became judge, policeman, customs officer, and every other officer all in one. He was universal ruler, not by appointment but by necessity. $\mathrm{He}$ did not interfere with Frenchmen; nor did the French naval officer interfere with Englishmen, or if he did he afterwards apologized. Atavism was in the air: and we seem suddenly transported back across the centuries to a time when the instincts of the race provided the same salves for the same sores. Indeed, the French fishing-ships, which crossed the ocean in spring and autumn, shadowed by half- 
a-dozen French cruisers, seemed an exact reproduction of the convoyed and convoying ships of the seventeenth century; and the idea which underlay the bounty system of France, that ocean-trips made ocean-ships and ocean-sailors, wherewith a nation alone became great, was a mere echo of voices which were hushed long ago. The lawless usurpation of naval officers tempered lawlessness in a way which old memories endeared. It was as though a cradle song which had no merit of its own, and had not been heard since infancy, were heard once more. It caused pleasure and not resentment.

Efforts The position was illogical, but intelligible to the naval were made to compromise officers and the simple fisher-folk. From 1844 to 1904 almost continuous negotiations were in progress to substitute logic for instinct, and to regularize the situation. The arguments of sixty years produced a dozen agreements which failed.

by the The first conspicuous failure occurred in 1857 . The abortive essence of the scheme of 1857 was partition. Fishing and AngloFrench the use of the strand for fishing purposes were to be exConvention clusively French on the north and north-east coasts, and at of 1857 , five reserved ports on the west coast ${ }^{1}$ the use of the strand for fishing purposes was to be exclusively French north of the Bay of Islands, and exclusively English at and south of the Bay of Islands, except at the reserved ports. The scheme made the home of the herring and the settlements at St. George Bay and the Bay of Islands wholly English; and Petit Nord-in an extended sense, including Croc, St. Barbe, Ingornachoix, and Bonne Bays-wholly French. In addition to these concessions, a new concurrent fishing-right in Labrador, and, as a last straw, a new right to buy or catch bait on the south coast, was conferred on France. ${ }^{2}$ Labouchère, the then Secretary for the Colonies, wrote that 'the

1 Port-au-Choix, Petit Port, Port-à-Port, Red Island, Codroy Island.

2 The Anglo-French Convention is printed in Accounts and Papers, 1857, vol. xviii, p. 7 , No. 2 I 57 . 
rights enjoyed by the community of Newfoundland are not to be ceded or exchanged without their consent', which consent 'is regarded as the essential preliminary to any modification of their territorial or maritime rights'. Accordingly Newfoundland, which had just received responsible government, was consulted, and spurned the Treaty, especially that part of it which referred to bait. The agitation which Newfoundlanders initiated in opposition to the proposed compromise was carried on, not only in their island home, but in Nova Scotia, where it is said to have promoted that scheme of North American confederation which Lord Durham proposed in 1839, and which Canadians consummated in 1867 , but from which Newfoundland ever afterwards held aloof. The old difficulties were unresolved, and and by a things went jogging along in the same old ruts and with the recurrence same unthinking acquiescence as in the early days of the regimes. History of Newfoundland.

Just as the opposing parties were settling down lazily and Then the happily into the old primitive habits there crawled across the lobster $_{\text {entered the }}$ political arena 'a large, marine, stalk-eyed, ten-footed, long- arena, $c$. tailed crustacean of the genus Homarus, much used for food, ${ }^{1880}$ and of a brilliant red when boiled.' The ugly ridiculous lobster thrust its claws into the tangle and all was confusion. Both Frenchmen and Englishmen, inspired by the lobster, began to go crooked.

Nova Scotians began to tin salmon and lobsters at the Bay British of Islands in 1858 , and lobsters only at St. Barbe in 1873 , lobsteries and at Brig Bay, a few miles north of St. Barbe, in $1880 .{ }^{2}$ haps, Port Saunders in Ingornachoix Bay, where Chappell admired French lobsters in 1813, was the next factory, and on the west coast being clearbetween St. George Bay and St. Barbe in August, 1887 , there ly against were twelve British lobster-factories, three-fourths of which ies;

1 March 26, 1857.

2 Correspondence respecting the Nerufoundland Fisheries, 1890 , vol. lxxxi, p. 37 (c. 6044); Dispatch, Jan. 26, 1889. 
were worked by Nova Scotians or Prince Edward Islanders, with the assistance of nearly $\mathrm{I}, 000$ Newfoundlanders as employees. In r 883-4, Messrs. Guibert, Lemoine, and Dameron, of St. Malo, entered the lists, and built two ironroofed or brick lobster-factories at Port-au-Choix and St. John Island, between St. Barbe and Port Saunders. Bricks were only less contrary to Treaty rights than stone; and Sir B. Walker discovered in 1890 permanent stone buildings, gardens, and cattle at Croc. ${ }^{1}$ Factory opposed factory, and lobsterers confronted lobsterers. The French contended, in defiance of natural history, that lobsters were fish, and that the canning of lobsters was the drying of fish within the meaning of the Treaties; and contended, with more plausibility, that the English lobster-fisheries and factories interfered with their legitimate cod-fisheries and must be closed. The more they complained and competed, the faster the new English industry developed. Political excitement attracted adventurers after adventurers; and in 1888 there were twenty-nine, in $\mathbf{1 8 8 9}$ forty, and in $\mathbf{1} 890$ seventy British factories, mostly Nova Scotian, and employing I,230 persons on the task of 'making the green one red'. At the same date there were only six French factories, all of them belonging to merchants of St. Malo, and employing 144 persons. The Frenchmen were being crowded out.

about the same time Governmental in. stitutions were set up on the Treaty shore, I 877 , I88I ;
The situation was complicated by political events inside the colony. In 1877 the whole of the Treaty shore was carved out into two electoral districts, one of which was called St. George Bay District, and the other of which corresponded to what the French used to call Petit Nord, and included the coastline assigned to France by the abortive convention of $\mathbf{I} 857$, and is now called St. Barbe District. The whole machinery of government-consisting of stipendiary magistrates with the powers of district Court Judges,

1 Dispatch of Admiralty, Jan. I5, I 890 in Accounts and Papers, I 890-I, vol. xcvi (c. 6256), at p. 87 . 
of constables, of sub-collectors of Customs, of post officials, and of Commissioners for issuing mesne process-was already at work at St. George Bay, the Bay of Islands, Bonne Bay, Flower's Cove, and St. Anthony in I88I ; and for a time the naval officer on the station was also invested with the authority of a local magistrate. The population on the Treaty shore numbered 9,000 in $188 \mathrm{I}$ and $\mathrm{I}_{3}, 000$ in I $89 \mathrm{I}$, and it was known beforehand that the French fishermen would not recognize local law, or those who tried to enforce it. The lobster was only the principal cause of strife, and men wondered what would happen if attempts were made to compel Frenchmen to obey the thousand and one laws in the local statute-book about seines, and nets, and close times for fishing, and Sunday observances, and the like.

It was plain that the lobster was one of many influences and there which were leading England and France towards war. other aborEnglish and French statesmen took the alarm, and in 1885 tive Anglosigned a new provisional convention, which once more de- Convenlimited the English and French fisheries, reserving to the tion, 1885, French, amongst other things, the neighbourhood of Croc, St. Barbe, St. John Island, and Ingornachoix Bays, and authorizing existing buildings on the reserved parts, and future as well as existing establishments and buildings for industries (except fishing industries) elsewhere. Dual naval control was provided, each naval officer controlling those of his own nation. Fishing-ships were exempt from port, light, and shipping dues, and fishing necessaries were exempt from import duties. Fish included fish caught on the sea, but were otherwise undefined. The word lobster was not even mentioned, but herring and capelin were mentioned; and the French were allowed to buy herring, capelin, and other bait freely. Newfoundlanders once more rebelled against the bait-clause, threw the Treaty on one side, and enacted the Anti-Bait Laws of 1886 and 1887 , which will be presently discussed. The Treaty was not wholly waste 
followed by paper, and England sent out naval officers 'to carry out the renewed spirit of the arrangement' of 1885 , except the bait-clause. the naval The English officers declared that hardly any lobster-factories make-shift; impeded the French fisheries; and the French officers admitted that this was correct in some cases. Wherever the French officer pointed out pots or nets, which were in the way of definite French fishermen, the English officer ordered the pots and nets to be removed while the French fishermen were actually fishing; and as soon as the French fishermen had finished the pots and nets were replaced. The French officer, at the request of the English officer, ordered French buildings of brick and stone to be taken down and they were duly left standing. The men of war proved men of peace, and to a and honour was satisfied. They even agreed to permit periodically lobster-factories to continue, and their agreement led to the
renewed modus vivendi pending an arbitration, intended but never held, jointly, if care was taken not to favour one nation at the 1889-1904. expense of the other. The modus was renewed from year to year, and involved the removal for a few hours of lobsterpots and herring-nets, and the closing of one or two new lobster-factories, for which a discontented mortgagee sued the naval officer with success, ${ }^{1}$ acts which scarcely belong to history. The modus was afterwards sanctioned by annual or triennial Acts of the local legislature between I89I and I904; and further unseemly litigation between St. John's merchants and officers of the Royal Navy, who alone stood between Newfoundland and a great war, was averted. The modus was meant to pave the way for arbitration on the lobster question, to which England and France assented between May I 889 and January $\mathbf{I} 89 \mathrm{I}$; but the ministers of Newfoundland urged a reference to the arbitrators of all

1 Baird versus Walker, Law Reports, 189I, A. C. 49 I. 
possible questions which might arise under the Treaties, and it was doubtful whether any arbitration would ever take place. France, moreover, was alarmed at the temporary character of the colonial laws sanctioning the modus and shelved the agreement for arbitration.

Doubtless the anti-bait laws crippled French fishermen on In $190_{4}$ the south coast ; but in the end the natural law, which almost the seemed invariable in the history of the colony, that stationary multitudes oust visitors from afar, asserted itself, and once more settled industry and numbers prevailed. Settlers on the Treaty shore increased to 17,234 in 1901 , and the harassed 'Entente Cordiale' solved these difficulties, Trence Bretons dwindled. Finally, in 1904, a way out of all these rights. difficulties was found, and the long entanglements caused by mutual and palpable evasions and violations of inviolable and impossible international engagements were brought to an end by the so-called 'Entente Cordiale'. There was a general taking of accounts and stock-taking by England and France all over the world, in Africa, Australasia, Egypt, and Newfoundland; a balance-sheet was struck, and France renounced her fishing and drying rights under the Treaty of Utrecht and the succeeding Treaties, and retained or received in their place a right to fish in the sea along the Treaty shore for cod, bait-fish, and lobster on terms of equality with the local inhabitants, and subject to local law. Priorities, privileges, exclusions, exemptions, and extra-territorial jurisdictions were swept away, the French warships went home, and nowadays Frenchmen fish, if they wish, on what was once the Treaty shore, side by side with the colonists just as though they were Englishmen from England.

The Anglo-French chapter-some four centuries long - The lobster closed; and the lobster, which darkened its closing para- disappeared graphs, ceased to be a force in history. tics,

The Anglo-American chapter is finished also, but until late and the in 1910 the herring bred strife. We left the trail of the herring somewhere in the Seventies in order to pursue the herring reappcarcd. voL. V. PT. IV 
red lobster which, so to speak, was drawn across the scent.

In Fortune The herring of the Seventies was not the herring of the Bay, dur. ing the winter herringfishery, Nervfoundlanders rioted and injured American property, 1878 ,

Fifties. In the Seventies it employed men all the year round. Fortune Bay had succeeded Placentia as 'the home of the herring'; the best herring-fishery in Fortune Bay was between November and February; and the herring, when taken, was put in ice, and bought and brought by American shipowners to Gloucester, Massachusetts. Frozen herring became an article of trade for its own sake as well as for the sake of cod, and its purchasers were almost invariably American. The temporary Treaty of $187 \mathrm{I}-86$ only enabled Americans to catch what they had previously bought, and they now pursued their industry in winter as well as in summer. Being protected, the Americans pursued their industry in a mysterious way. The Boston Fish Bureau wrote that 'From 50 to 75 per cent. of the men in the Gloucester mackerel fleet are citizens of Canada. ... Hordes of them come here every spring, man our vessels for the fishing season, and return home when it is over'. 1 As soon as the Americans arrived in Newfoundland, Newfoundlanders sold them bait, or served on their ships while catching bait, and were always paid cash. Wageearning was popular, and cash was as welcome as it was rare; because it meant emancipation from the merchant whose dominion was based on credit in kind. Americans were never at a loss for bait-sellers or bait-catchers in Newfoundland, and bait-fish was the only thing which they wanted. The American codders caught cod on the Grand Banks, despised shore fisheries, and spoke of flakes and stages as cotton-spinners speak of handlooms. If they wanted herring as bait they wanted it in a hurry, and if they wanted herring as food, even then they relied on the man on the spot to haul

1 Dispatch of Sir L. S. West, Oct. Io, I885, in United States, Correspondence relative to the North American Fisheries, Accounts and Papers, I887, vol. xci (c. 4937). 
their seines. Shortly after the second Treaty of Washington some Gloucester vessels came into Long Harbour, Fortune Bay, and used seines, superior in size to those of the Newfoundlanders, in such a way as to bar the herrings in the inlet, on a Sunday in January, 1878 . There was a riot; an American seine was torn, and the Americans lost, or said that they lost, the season's fishing. Similar events occurred in Conception Bay and elsewhere while Americans were catching their summer bait between 1877 and 1880 . Then (similarly in Conception Bay) England paid to the United States by way of moral and intellectual damages $f_{\mathbf{I}}, 85^{\circ}$, one-fourth of which was afterwards repaid by Newfoundland to England, and no further unpleasantness occurred.

During the discussions which accompanied these events both sides startling discrepancies were disclosed between the points of violated $^{\text {having }}$ view adopted by English and American statesmen, and even local law, English and colonial statesmen did not quite see eye to eye. Colonial as well as English statesmen pointed out local laws, passed in 1862 and 1876 , which forbad the use of seines between October and April, and which absolutely forbad inbarring and Sunday hauling; but English naval officers had again and again called attention to the ignorance displayed by Newfoundlanders of the American Treaty rights and of their own fishery laws, and complained that both were daily violated by Newfoundlanders with impunity, and that the police of the sea-fisheries was wholly inadequate. How, then, could Great Britain insist on obedience by aliens to laws which the colonists habitually disregarded, and which the colony took no pains to enforce? But this was an objection which time and energy would inevitably remove. A far more serious situation was created when the Americans, taking the Ameria leaf out of the French book, contended that they were not cans claimbound by ing to be bound by local laws, either anterior or posterior to the Treaty. above local After the Treaty terminated the gulf widened and Newfound- law. land passed the anti-bait laws which have been referred to, 
and which came into force in 1888 . This was the year in which the French question was more menacing than it had ever been, and the anti-bait laws were aimed equally at France and at the United States. Nerufound- The Anti-bait Act, 1887 , carried former Acts, which im-
land retaliated by enacting anti-bait laws, 1887 et seq., with penalties, posed an export duty on bait-fish, and which had been extinguished by the Reciprocity Act of 1854 , one step further. It was modelled too on similar Canadian laws, ${ }^{1}$ which prohibited sales of bait by unlicensed persons, and which were only suspended during the prevalence of reciprocity. In the Act of 1887 , as amended by Acts passed in 1888 and 1889 , not only 'catching and selling bait-fish for export', but 'putting' and 'conveying them on board of any ship for any purpose whatever', was included in the prohibition. As in the Canadian Acts, the penalty consisted not only of a fine, but also of confiscation of the offending ship with its boats and tackle, the latter drastic penalty being derived from an English Act of 1819, which provided for the execution of the American Treaty of 1818 . It is, however, arguable that both the English Act and the Treaty of 1818 were dictated by archaic ideas of international law which were prevalent at that time.

derived from an English precedent of 1819 ,
The argument, which is plausible, may be stated thus:Before 1818 England claimed the Gulf of St. Lawrence as a British Lake, although Cabot Strait is nearly sixty miles and Belle Isle Strait is nearly ten miles across; but the Treaty waived this claim in the case of inhabitants (not ships) of the United States, who fished between Ramea Islands, Cape Ray, and Quirpon, or in or off Labrador east or north of Mount Joli. The fishery was a sea-fishery 'in common with' British subjects, and included drying and curing rights on the unsettled parts of Labrador, and of the said south coast of Newfound-

1 Canadä, 3 I Vict. c. 6r ; 33 Vict. c. I5; 34 Vict. c. 23 ; Prince Edward Island, 6 Vict. c. I 4 ; and various laws of New Brunswick and Nova Scotia. 
land, and a right to put to shore 'for the purpose of shelter and of repairing damages therein, of purchasing wood and of obtaining water, and for no other purpose whatever.' 1 The Act also allowed all foreigners to fish anywhere outside the three-mile limit. The Act was an enabling Act, and threw the Gulf open to the whole world, special privileges being bestowed on the Americans. In order to enforce these new rules of international law, the king was empowered to make regulations by Order in Council, which should be as valid as an Act of Parliament, overriding Colonial laws, but leaving foreigners untouched, and the penalty on foreigners 'found fishing or to have been fishing or preparing to fish' in places not authorized by the Act was confiscation of their ships, boats, and tackle. But bait-buyers were traders, and neither Treaty nor Act dealt with traders as opposed to fishermen; although by the comity of nations Americanand British traders have visited one another's harbours freely ever since 1830 . Consequently, it was said, American fishing-vessels, which put into shore in order to buy bait, violated the italics in the Treaty, and were liable to the penalty devised by the English Act of I 8 I9 and revived by the Canadian and Newfoundland Acts. The authors of the Colonial Act of 1887 appealed triumphantly to the English Act of 18 r 9 , but their appeal would only have been relevant if the same principles of international comity had been prevalent in 1818 and 1887 .

They also based their legislation upon common sense and andvarious said:-Why should we sell bait cheap to rivals who are out- arguments selling us by means of bounties and the like? The maxim ency. of our opponents is not 'live and let live', but 'let others live by killing us'. If France were to seize the Mediterranean, and if the United States, which has already closed its own markets to us, were to seize the Brazilian market with our help, where should we sell cod? If the cod-market were destroyed Newfoundland would be destroyed. If, too, herring

1 The italics are mine. 
were taken too quickly, herring would go, and all the colony would follow all the cod, and all the cod would follow all the herring, into ' chaos and eternal night'. No herring no cod, no cod no colony. These arguments seemed unanswerable from the point of view of expediency. The Colonial Legislature were in grim earnest, bought two revenue steamers, and instituted a fishery board, with Adolf Nielsen, a Norse expert, as president, thus restoring the descendants of Karlsevne to the scene of his discoveries. Remissness in enforcing fishery laws became a thing of the past.

The Brit- The United States were also in earnest, and identified

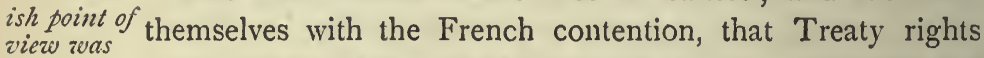
opposed to could not be impaired by provincial laws. Although the that of the United States on the question of sozereignty. French cause so nearly resembled the American cause, the two Powers never made common cause, and England was not faced by a coalition, as she had been in the early days of the nineteenth century. French statesmen had claimed French fishing-rights as a relic of French sovereignty, recognized but not created by Treaty, and a similar metaphysical view of the Treaty of 1818 was now broached. It was contended that in $I 783$ 'the fisheries were not conceded, but recognized as a right inherent in the Americans, which, though they had ceased to be British subjects, they continued to enjoy ', ${ }^{1}$ and that this right, like American Independence, was suspended without being destroyed by the American war of i 8 I2. The view expressed by an official American circular in $185^{6}$, that 'observation' of Colonial Acts and Executive Regulations 'is enforced upon the citizens of the United States in the like manner as they are observed by British subjects', was now repudiated by the United States. English statesmen unanimously opposed the new line of argument, which American diplomats now adopted, although in discussing the Treaty of Washington Lord Salisbury and Lord Granville admitted that local regulations must be reasonable and bona 1 Citing Lord Loughborough. 
fide, and the same admissions were made with regard to the Treaty of $1818 .^{1} \quad$ Neither Lord Salisbury nor Lord Granville defended vindictive laws, which were meant to nullify the concessions of 1818 . On ascertaining that this was the official British view the Americans ${ }^{2}$ offered to consult with the British legislature in order to devise what was reasonable for the protection of the fisheries. But dual control is the antithesis of sovereignty, and the opposition was none the less serious because its practical scope was small. British sovereignty was uncompromisingly challenged by the United States, and uncompromisingly upheld by British statesmen, as in the case of France; and the only reason why the American fishermen were not attended by a war-ship was that the United States did not wish to dispute British sovereignty in a vexatious way. ${ }^{3}$ As a first step the United States sent an unarmed Government steam-ship to the critical spot in 1906 and subsequent years. Ever since I886, American fishermen, who fished for bait, had from time to time defied local regulations as to seines, Sunday fishing, port dues, and the like; although until 1905 their defiance was usually followed by submission under protest. Now that their Government was represented at the scene of disturbance these protests were sure to lead to political results.

Statesmen would not be statesmen unless they recognized There was the serious nature of the outlook; but, as Lord Rosebery said ${ }^{4}$ :- If the provisions of the Convention of $18 \mathrm{I} 8$ had become a $T$ pt at inconvenient, the utmost that goodwill and fair dealing could ${ }^{1888,}$ suggest was that the terms should be reconsidered. New treaties had been made on two occasions, and on each occasion had been terminated by the United States. England had done her duty and was willing to do it again, but

1 Dispatches, Nov. 7,1878 ; Oct. $27,1880$.

${ }^{2}$ See e. g. Accounts and Papers, 1906, vol. cxxxvii (Cd. 3262), p. I4.

3 Dispatch, July 20, 1906.

4 Dispatches, \&c., Dec. 26, 1884; May 29, 1886; June 2, 1886; July 23,1886 . 
could not go 'as a suitor' to the United States. Nevertheless, a third Treaty of Washington was negotiated by Joseph Chamberlain and T. F. Bayard in $\mathbf{I} 888$, and thrown out by the American Senate. The third olive-branch was rejected and the Treaty was stillborn. But it contained a modus which con- vivendi pending ratification ; and American ships were allowed tained a temporary modus vivendi;

by the modus to take out licences to buy bait, ice, seines, and tackle, to ship crews, and to tranship cargo for $\mathbf{I} \frac{1}{2}$ dollars a ton, or without payment if the United States admitted fish and fish-products freely. Fishing-ships which confined themselves to the objects specified in the Treaty of 1818 and did not communicate with the shore need not enter or clear at the Custom House. The modus expired in 1890 .

and new Treaties were attempted in 1890 ,

Then a strange interlude took place. In September, I 890, Sir R. Bond, the able and energetic ex-Premier of Newfoundland, was permitted by the English Government to present his views directly to the English Ambassador at Washington, who permitted him to negotiate informally with J. G. Blaine, the American Secretary of State; and the negotiations were expressed in the form of ' a draft of a convention embodying the arrangement proposed by the Newfoundland Government'. In December this draft was remodelled by Sir R. Bond in concert, not with the English Ambassador, but with Mr. Blaine, who in January presented a counterdraft which 'the United States Government would not be unwilling to accept, but they were not anxious for the arrangement'. The drafts and counterdrafts, whether original or remodelled, differed materially. At an early stage of the proceedings, Canada protested against separate action by Newfoundland in a matter in which Canada was equally concerned, and the negotiations ended in nothing. From which Sir R. Bond inferred that a Bond-Blaine Treaty was virtually concluded, when Canada and 1902. prevented it; but he was alone in his inference. In 1902 an authentic and real separate agreement, called the Hay-Bond Treaty, was concluded similarly and on similar lines, but was 
rejected by the American Senate. For the whole period between 1890 and 1904 , Newfoundlanders were licensed to sell, and Americans were allowed to buy bait freely off the coasts of Newfoundland. In 1905 there was an armed truce, during which Newfoundland passed the Foreign Fishing Vessels Act, in order to enforce the anti-bait Acts which were consolidated in $\mathbf{1 8 8 9}$.

The Act of 1905 was little more than the re-enactment of Nerv antian Act which was passed in 1893 , but was never enforcedbait Acts.

and provided $(a)$ that a foreign fishing-ship within the three- passed, mile limit might be boarded, brought into port, and searched; ${ }^{1905}$, 1906, and $(b)$ if it had bought bait within, or hired Newfoundland sailors within (or without) the jurisdiction, it incurred confiscation; and $(c)$ the possession of bait-fish was prima facie evidence that they had been purchased illegally. The words in brackets were added in 1906 but did not become law.

This Act poured oil upon the smouldering flames. In which 1905 the principal winter fishery for herring was for consumption, not for bait, and was situated in the Bay of Islands, the Bay of where herring were caught during nine months in the year. caused friction at Islands The glory had departed from Fortune Bay. The herring of the Bay of Islands came, like the St. Malo men of old time, from the north through Belle Isle Strait, and were not the herring that visited St. George Bay in the spring. It was said, too, that they were changeful in their habits, and had been driven from adjacent creeks by American purse-seines. In December, 1906, there were 65 American herring-ships, on which 780 Newfoundlanders, who had been engaged outside the three-mile limit, were serving for cash. Canadians were also present in the Bay of Islands, where the Canadian fleet was second only to the American fleet, numbered 27 ships, and bought bait from 488 Newfoundlanders. Local craft, amongst which the St. George Bay herring-fleet was conspicuous, employed 577 , and the shore fishery 180 Newfoundlanders. The Canadians had an 'establishment' on 
shore, and the Canadian ships were licensed to buy bait. The Americans were unlicensed, and when Newfoundlanders worked for them they offended against the laws of 1889 and 1905. Their offence was especially rank as the American vessels brought purse-seines, practised Sunday fishing in disobedience to local law, and refused to pay light and port dues or to clear at the custom-house.

and a new AngloAmerican modus zuas made, and cnforced by the Royal Navy and by Ameri. can Fishery Commissioners.
Fearful of a collision, the English and American Governments patched up a modus vivendi, which made light dues and custom-house clearances compulsory, permitted purseseines, prohibited Sunday fishing, and suspended the provisions summarized in the clauses marked $(a)$ and $(c)$ in the Act of 1905 , and those provisions in the Act of 1906 which were not in the Act of 1905 . Shipments of Newfoundlanders outside the three-mile limit were not to be penalized. Captain R. H. Anstruther, of H.M.S. Brilliant, and Mr. Alexander, U.S. Fishery Commissioner in the U.S. Naval Tug Potomac, watched over the modus. Once more the men of war proved peacemakers, and Captain Anstruther and Mr. Alexander added an informal rider to the modus that the Newfoundlanders were to abandon night-fishing and the. Americans the use of purse-seines. The modus and its rider were observed, although their only legal sanction was Salus reipublicae suprema lex, and when the Government of Newfoundland prosecuted two Newfoundland fishermen named Crane and Dubois-who had shipped on an American vessel outside the three-mile limit-for 'putting on board' the vessel 'bait-fishes for export', they won a cheap legal success. Crane and Dubois were prosecuted and fined under the anti-bait Act $\mathbf{1 8 8 9}$, or, rather, under a recent re-enactment of that Act ${ }^{1}$; but it was thought that they had acted in pursuance of the spirit, although they were not protected by the language of the modus, and their fines were paid by the English Government.

Next year a new modus was entered into. It prohibited

1 Consolidated Statutes (Series ii), ch. 129, Sect. I, sub-sect. 5. 
purse-seining, and confirmed future agreements which might Then a ncro be made locally, but was otherwise the same in its contents as last year. But its nature was different. In the first place arbitration it was the prelude to arbitration. Arbitration had been woas agreed suggested on September 3, 1906, by the Earl of Elgin to the friction in Newfoundland Government; and on June 15, 1907, the Nervfoundlatter consented to refer the question of jurisdiction to the Hague Tribunal, provided that all other questions which could be raised under the Treaty, including those mentioned ante pp. I35, 136, were similarly referred. On July 1 2, 1907, the American Ambassador also suggested arbitration, which was accepted by the Earl of Elgin, and the modus was merely tacked on to the agreement for arbitration. Fifteen years ago an Anglo-French modus was similarly tacked on to an agreement for arbitration, and the French wanted to narrow and the Newfoundlanders to widen the terms of reference, so that no arbitration took place. Consequently pessimists foretold that the temporary modus would become perpetual. The Newfoundland Government, having had no little experience of the gradual conversion of annual into perpetual things, proved intransigent, and refused to give legislative effect to the modus. The English Government then issued an Order in Council, which derived its force from the same source as that from which every anti-bait Act derived its penalties, namely, from the English Act of 1819, and which annulled the provisions summarized in clauses $(a)$ and $(c)$ of the Act of $\mathrm{I}_{905}$, so far as regarded American vessels, and made the consent of a British naval officer the condition precedent of service of process on ships, or seizure of ships' boats or tackle, which were engaged in the exercise or alleged exercise of the Treaty Rights. Under the provisions of the Act of 1819 , the Order in Council prevails over local law, but it would seem that proceedings against offenders against local laws like Crane and Dubois are still possible, if instituted against them after they have left the foreign ships on which they 
served. American ships' boats and ships' tackle, and Newfoundlanders, while on board American ships, were shielded by the Order in Council; but on leaving the employers' ships the personal immunity of Newfoundlanders ceased. Such was until I 909 the end which is no end of the dispute between English residents and American visitors, about herrings. In 1909 , terms of reference were agreed to, and in I 9 ro arbitration at the Hague took place. ${ }^{1}$

Whaling now began seriously.

Even the sea has its surprises, nor are all marine industries so everlasting and unchangeable as the industries connected with the cod; and just as the last chapter of the sea history of Newfoundland seemed finished the whale made a new beginning. In the Thirties and Forties Gaultois in Hermitage Bay was the head-quarters of whaling, which brought in $£_{1,000}$ to $\AA_{2,000}$ a year. ${ }^{2}$ The same amount was yielded in $1869-75 .^{3}$ The monster who contributed these mites to the wealth of Newfoundland was the Right Whale. After I 880 Norsemen perfected methods of attack against the Humpback, and the Blue and Common Rorqual, which proved so deadly that in a few years these whales were nearly exterminated in Finmark (Norway). Then in 1897 the Norsemen, who already had a distinguished representative - Mr. A. Nielsen-on the Newfoundland Fishery Board, started operations at Snook's Arm in Notre Dame Bay and at Balaena in Hermitage Bay, with the astonishing results which are tabulated below. The new whaling steamships, companies, captains, and crews were Norse, in spite of legislative protests to the contrary; and it is as yet doubtful whether whaling on this gigantic scale will become a native or permanent pursuit. ${ }^{4}$

There is no civilized nation in the world which is so

1 See post, Appendix F.

2 Accounts and Papers, 1850 , vol. xxxvi, No. 1232.

$3 £ 2,300$ per annum, Accounts and Papers, 1878, vol. 1xxx (c. 2056).

4 Smithsonian Contributions to Knowledge, Washington, vol. xxxiii, 1904; J. G. Millais, Nerefoundland and its untrodden ways, I907; Fishery, Commission of Nerufoundland, Annual Reports. 
marine in its character as Newfoundland. The sea has The sea asserted its sway over Newfoundlanders; they are wedded with governs the the sea and 'their children's eyes change colour with the sea'. NerufoundCod, seals, herrings, whales, and the clownish lobsters mould land; their destiny, and their pathway to reality lies through a life dedicated to the sea.

It is sometimes hard to distinguish causes from effects in history, for effects mesmerize men's souls, which are the media through which causes operate, so that effects react on causes. But if anything in history can be considered a pure unadulterated cause, the sea-with its bays and productsis the first cause of the life, character, industry, government, and history of Newfoundland. The chief places are bays like Conception Bay, creeks like St. John's, or islets like Greenspond, Fogo, and Twillingate; and its institutions were only outward and visible signs of abiding geographical influences. Old-fashioned theories about population, sea-power, and economics, which were neither right nor wrong but only suitable, co-operated with the conditions imposed by nature until the nineteenth century. Then facts were too many for the theorists, and settlers won their fishing victory over visitors, and in the hour, perhaps because of their victory, these old-fashioned theories became unsuitable and crumbled in the dust. In the last century, without any help from theories, the old geographical facts began once more to produce the old historical effects, and Burin became a second St. John's, St. George Bay a second Conception Bay, and Burgeo a second Twillingate. It is true that in this last century Treaties had a little to do, just as theories once had much to do, with the process; yet Treaties like theories were only symbols and expressions of the idea men had of the situation, and their idea was not invented but was a mere reflection of geographical facts. Laws, Treaties, and theories had not much more to do with the history of Newfoundland than its froth has to do with the rapids of Great Rattling Brook. 
its towns lie on the sea,

and all its industries are export industries.

What distinguishes Newfoundland from other countries is that after four centuries of history it has no town or settlement of any importance-if Grand Falls is excepted-so far from the sea as Athens, Rome, or London, and all its coves are occupied by what once were, and in many cases still are family settlements. Moreover, although fresh-water influences have been present in its history for at least two centuries, not one of its seaside towns or important seaside settlements is situated on a river of any importance except the Bay of Islands, where some day hence a river-city may arise.

The following table, which only relates to a period after mines and railways and lumbering began, and after the Treaty shore was endowed with political institutions-not so much in order to promote, as in consequence of its having attained manhood-illustrates the geographical factors, the fauna, and the flora, and the minerals, which are the present Fates and Norns of Newfoundland. It will be remembered that exports gauge and comprise almost all the industrial life of the community, and it will be observed that some six or seven exports are almost synonymous with all the exports, and all the exports are almost synonymous with all the industries of the community. Newfoundland is one of those communities where the web of life consists even in these latter days of six or seven threads and no more, and is an instance of a State absolutely dependent on World-Trade, yet absolutely simple. 
AnNual Value of Exports $\times £ i, \infty 00$.

Cod

Seal

Herring 1

Cobster

Whale ${ }^{2}$

Salmon

Total products of sea

Total land products,

ante, p. I 82

Total of principal products exported

Total exports (average)

Total imports(average)

\begin{tabular}{|c|c|c|c|c|c|}
\hline $\begin{array}{c}a v . \\
188 \mathrm{I}-5\end{array}$ & $\begin{array}{c}a v . \\
1886-90\end{array}$ & $\begin{array}{c}a v . \\
189 \mathrm{I}-5\end{array}$ & $\begin{array}{c}a v . \\
1896-1900\end{array}$ & $\begin{array}{l}a v . \\
\mathrm{I} 90 \mathrm{I}-5\end{array}$ & $\begin{array}{c}a v . \\
\mathrm{I} 907-84\end{array}$ \\
\hline 1060 & 849 & 849 & 890 & I 265 & $168 I$ \\
\hline I 68 & II 8 & I 2 I & 95 & $\mathbf{1} 48$ & 92 \\
\hline $34^{1}$ & $43^{1}$ & 45 & 35 & $7 \mathrm{I}$ & 82 \\
\hline 16 & 72 & 74 & 104 & 89 & 85 \\
\hline $4^{2}$ & $I^{2}$ & I & 2 & $4^{6}$ & 39 \\
\hline I5 & I7 & I 4 & I5 & I7 & II \\
\hline 1297 & 1100 & $\mathrm{IIO}_{4}$ & I I 4I & 1636 & I990 \\
\hline $5^{8}$ & $6 I$ & I 29 & I 54 & 287 & 348 \\
\hline I $355^{3}$ & I I 6I 3 & I 233 & 1295 & $19^{23}$ & $233^{8}$ \\
\hline $13^{82^{3}}$ & $1232^{3}$ & I32I & I330 & 2012 & $23^{88}$ \\
\hline 1630 & I $29 \mathrm{I}$ & I33I & I 237 & I 757 & 2360 \\
\hline
\end{tabular}

1 I add frozen herring as per Newfoundland Bluebooks (which omit I88I).

2 Includes bone.

3 Exclndes Labrador before 1886.

4 Taking the dollar at $4 s, 1 \frac{1}{5} d$.

The lists of imports in the last line of the Table are given Exports for purposes of comparison. In all healthy colonies or payfor young states there is a normal excess of exports over imports, and public

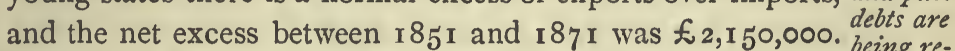
During this period the State debt was only a little larger than paid. its annual revenue, and there was but little other debt of a public character. Next, came a period of large expenditure from loans on railways, docks, telegraphs, and other public works by private capitalists and the State, in consequence of which between $\mathrm{r}_{772}$ and $\mathrm{r}_{994}$ imports exceeded 


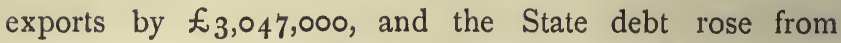

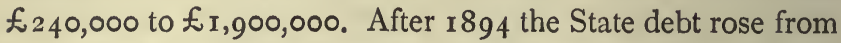
$\AA_{I, 900,000}$ to $\AA_{4}, 600,000$, in spite of which between 1894 and 1908 exports exceeded imports by more than two million pounds, that is to say by the average annual imports of a few years previously. The explanation of this anomaly is-first, that the increase of the State debt represented to a large extent a mere transfer of past debt from capitalists to the State; secondly, that the debt so transferred was reproductive, and paid interest and repaid part of its principal; thirdly, that things had returned to normal.

Some of these figures as to the State debt are given in the following Table, which relates mainly to population.

Immigration plays little part.

There has been very little immigration into Newfoundland during this period. The import of West of England fishermen for two summers and a winter seems to have continued until the Thirties, and in $\mathbf{1} 848$ Sir J. Gaspard Le Marchant wrote that 'vast bodies of emigrants' had come from Ireland bringing typhus. This year was a record year for immigration from the United Kingdom; the grand (or little) total being 993, of whom 757 were Irish. During thirty-four years (1842-75) Irish immigrants numbered 4,940, English and Scotch 2,702 , making a puny total of 7,642 immigrants. The population quadrupled itself in fifty years ( 1822 et seq.) by means of natural increase. As for revenue, in 1822 the cost to England of the garrison of St. John's exceeded the cost to Newfoundland of its whole government, and the government was poor until it became free. Under autocracy (r822) revenue was $4 s$. $6 d$., under Council ros., under representative government I $2 s$., and under responsible government between $\AA_{1}$ and $\AA_{2}$ a head. Democratic governments were far richer than those that were less democratic. Figures as to expenditure and as to State debts in early times are omitted, because they are of no importance. 


$\begin{array}{lcccccc} & 1822 & 1827 & 183^{6} & 1845 & 1857 & \\ \text { Population } \times 1,000 & 52 & 60^{1} & 77^{1} & 98^{1} & 125^{2} & \\ \text { Revenue } \times £ \mathrm{I}, 000 & 9 & 30 & 46 & 60 & 149 & \\ & & & & & & \\ & 1869 & 1881 & 1891 & 1901 & 1906 & 1907 \\ \text { Population } \times 1,000 & 149^{2} & 169^{2} & 202^{3} & 221^{3} & & 230(?) \\ \text { Revenue } \times £ \mathrm{I}, 000 & 177 & 217 & 379 & 4^{23} & 547 & 565 \\ \text { State Debt } \times £ I, 000 & 24^{2} & 281 & 1,088 & 3,570 & 4,448 & 4,599\end{array}$

1 Includes 2,000 estimate for Treaty shore.

2 Includes 2,000 estimate for Labrador (according to J. L. Prendergast in 1857 ).

3 Includes 4,000 for Labrador.

\section{AUTHORITIES}

In addition to the authorities mentioned at the end of chapters, innumerable bluebooks must be mentioned, amongst which-

The Proceedings of the Halifax Commission are reported in Accounts and Papers, 1878 , vol. $1 \mathrm{xxx}$ (c. 2056).

Correspondence, relating to the Newfoundland Fisheries, the Bait Acts, the disturbances in Fortune Bay, the proposed Conventions, Treaties, and Arbitrations, have been almost annual between I 878 and 1906. Some of the more important references are given in the foot-notes.

Sir W. MacGregor made an interesting Report on the foreign Trade of Nerufoundland in 1905, vol. liv (cd. 2480).

The views referred to on $\mathrm{pp}$. $217-18$ included those of the Government of Newfoundland. The 'arguments', on pp. 228-9, were put very forcibly by Mr. Dana at the Halifax Commission. The British official view differed from both from time to time.

The best available account of the arbitration at the Hague, referred to on p. ${ }^{236}$, appeared in the Times and other newspapers of Sept. 8, I910, and is reproduced more or less in Appendix F., post, 253-62. 


\section{APPENDICES}

\section{APPENDIX A (pp. $3^{6-7}$ ante)}

(State Papers, Domestic, Elizabeth. Vol. cxviii. No. 12.)

Adiscourse I am bowld (most excellent Soueraigne) to exercise my pen how her Maiestie may annoy the K. of Spayne. touching matters of state, because I am a syllie member of this Common weale of England, and doe not offer my self therein as an Instructor, or a reformer, but as a Welwiller to $\mathrm{yo}^{\mathrm{r}} \mathrm{Ma}^{\text {tie }}$ and my Contrie, wherein the meanest or simplest ought not to yeeld them selves second to the best, or wisest. In $w^{\text {ch }}$ respect I hope to be pardoned, if through want of iudgement I be mistaken herein. And as to the matter.

The safety of Principates, Monarchies, and Comon weales, rest chiefly on making theire enemies weake, and poore, and themselves strong and rich....

First $\mathrm{yo}^{\mathrm{r}}$ highnes owght vndoubtedly to seeke the kingdome of heaven, and vppon that fowndacion to beleeve that there can never be constant, and firme league of amytie betwene those princes, whose devision is planted by the woorme of theire consciences. So that theire legues and fayre wordes, ought to be held but as Mermaydes songes, sweete poysons, or macquesites, that abuse $w^{\text {th }}$ owtward plawsabilytie, and gay showes. For in troth as in such leagues there is no assurance; so christian princes ought not for any respect to combyne themselves in amytie $w^{\text {th }}$ such as are at open and professed warres $w^{\text {th }}$ God himself. For non est consilium omnino contra Deum. So that no State or common weale can florishe, where the first and principall care is not for Goddes glorie, and for thadvaunsing of the pollisies of his spirituall kingdome, $\mathrm{w}^{\mathrm{ch}}$ don, $\mathrm{yo}^{\mathrm{r}} \mathrm{Ma}^{\text {tie }}$ is to thinck that it is more then tyme to pare theire nayles by the stumpes, that are most readie prest to pluck the crowne (as it were in despite of God) from $y^{r}$ highnes head, not only by foraine force : but also by stirring vp of home factions. And therefore the best waie is first to purge, or at least wise to 
redresse yo ${ }^{r}$ owne kingdome of theire suspected adherents, I meane not by banishment, or by fire, and sworde, but by dimynishing theire habilities by purse, creditt and force. Then to foresee by all dilligente meanes, that yo $^{r}$ suspected neighbors may not haue opportunity to recover breath whereby to repayre theire decayed losses ; $w^{\text {ch }}$ for yo $^{r}$ safetie is principally to be don, by the farther weakning of theire navies, and by preserving and increasing of yo ${ }^{r}$ owne.

And the deminishing of theire forces by sea is to be done eyther by open hostilytie, or by some colorable meanes; as by geving of lycence vnder letters patents to discover and inhabyte some straung place, $w^{\text {th }}$ speciall proviso for theire safetyes, whome pollisy requyreth to haue most annoyed by $w^{\text {ch }}$ meanes the doing of the contrarie shalbe imputed to thexecutors fawlt; yo ${ }^{r}$ highnes letters patents being a manyfest shewe that it was not yor $\mathrm{Ma}^{\text {ties }}$ pleasure so to haue it. After the publick notyse of $w^{\text {ch }}$ fact, $\mathrm{yo}^{\mathrm{r}} \mathrm{Ma}^{\text {tie }}$ is either to avowe the same (if by the event thereof it shall so seme good) or to disavowe both them and the fact, as league. breakers; leaving them to pretend yt as done $\mathrm{w}^{\text {th }}$ out $\mathrm{yo}^{\mathrm{r}}$ pryvitie, either in the service of the prince of Orange or otherwise.

This cloake being had for the raigne, the way to worke the feate is to sett forth vnder such like colour of discoverie, certayne shippes of warre to the $\mathrm{N}$. L. $\mathrm{w}^{\mathrm{ch}} \mathrm{w}^{\text {th }} \mathrm{yo}^{\mathrm{r}}$ good licence I will vndertake $\mathrm{w}^{\text {th }}$ out $\mathrm{yo}^{\mathrm{r}} \mathrm{Ma}^{\text {ties }}$ charge, in $\mathrm{w}^{\mathrm{ch}}$ place they shall certainely once in the yeere meete in effect all the great shipping of Fraunce Spayne, and Portyngall, where I would haue take and bring awaye $\mathrm{w}^{\text {th }}$ theire frayghtes and ladings, the best of those shippes and to burne the woorst, and those that they take to carrie into Holland or Zeland, or as pirattes to shrowd them selves for a small time vppon yo ${ }^{r} \mathrm{Ma}^{\text {ties }}$ coastes, vnder the frendship of some certaine viceadmirall of this Realme; who may be afterwardes committed to prison, as in displeasure for the same, against whose returnes, six monethes provision of bread, and fower of drinck to be layd in some apt place : together $w^{\text {th }}$ municion to serve for the number of five or sixe thousand men, $w^{\text {ch }}$ men $w^{\text {th }}$ certaine other shippes of warr being in a readynes, shall pretend to inhabit $S^{\text {te }}$ Lawrence Iland, the late discouered contries in the North, or elswheare ; and not to ioyne $w^{\text {th }}$ the others; but in some certaine remote place at sea. 
The setting foorth of shipping for this service will amounte to no great matter, and the retourne shall certainly be $w^{\text {th }}$ greate gayne, for the N.F. is a principall and rich and euerie where vendible merchaundise: and by the gayne thereof, shipping, victuall, munition, and the transporting of five or six thousand soldiors may be defrayed.

It may be said that a fewe shippes cannot possiblie distres so many : and that although by this service yow take or destroy all the shipping you find of theirs in those places : yet are they but subiectes shippes, theire owne particuler navies being nothing lessoned therby, and therefore theire forces shall not so much be diminyshed as yt is supposed whereunto I answere

There is no doubt to performe it $w^{\text {th }}$ out daunger, for although they be many in number, and great of burthen, yet are they furnished $\mathrm{w}^{\text {th }}$ men, and munition but like fishers, and when they come vpon the coastes, they do alwaies disperse then selves into sundry portes, and do disbarke the most of theire people into small boates for the taking, and drying of theire fish, leaving fewe or none abore theire shippes; so that there is as little doubt of the easye taking and carying of them away as of the decaying hereby of those princes forces by sea, for theire owne proper shippinges are very fewe, and of small forces in respect of the others, and theire subiectes shipping being once destroyed yt is likely that they will never be repaired, partly through the decaye of the owners, and partly through the losses of the trades whereby they maynteyned the same. For euerie man that is hable to build shippes doth not dispose his wealth that waye, so that theire shipping being once spoyled, it is likely that they will never be recouered to the like number and strength but yf they should, yt will requier a long time to season timber for that purpose, all $w^{\text {ch }}$ space we shall haue good opportunity to proceed in our farther enterprises. And all the meane tyme the foresaid princes shall not only be disapointed of theire forces as aforesaid, but also leese great revenues, $w^{\text {ch }}$ by traffick they formerly gayned; and shall therew ${ }^{\text {th }}$ all endure greate famine for want of such necessarie victualles \&c. as they former enioyed by those voyages. ...

To prevent theise daungers (that although yor highnes may at the first distres both the French Spanyshe, and Portyngall yet there needeth none to be towched but the Spaniardes, and 
Portingall; or the Spaniardes alone, by the want of whose traffick there is no necessity of such decaye and losses as partly appeared by the late restrainte betwene $\mathrm{yo}^{\mathrm{r}} \mathrm{Ma}^{\text {ty }}$ and them. And the forces of the Spaniardes, and Portingalls, being there so much decayed as aforesaid; the French of necessitie shalbe

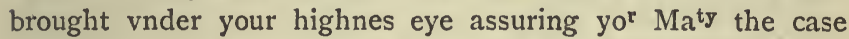
being as it is, it were better a thousand folde thus to gayne the start of them, rather then yerely to submitt $o^{r}$ selves subiect to haue all the marchauntes shippes of this Realme stayed in theire handes ; wherby they shalbe armed at our costes, to beate vs $w^{\text {th }}$ roddes of our owne making, and our selves thereby spoyled both of our wealth and strength. ...

But if yo $^{\mathbf{r}}$ highnes will permit me, $\mathrm{w}^{\text {th }}$ my associates, eyther overtly or covertly to perfourme the foresaide enterprise : then $\mathrm{w}^{\text {th }}$ the gayne thereof there may be easely such a competent companie transported to the W. I. as may be hable not only to disposses the S. thereof, but also to possesse for ever yor ${ }^{r} \mathrm{Ma}^{\text {tio }}$ and Realme therew ${ }^{\text {th }}$, and thereby not only to countervaile, but by farr to surmount $w^{\text {th }}$ gaine, the aforesaid supposed losses : besides the gowld and silver Mynes, the profitt of the soyle, and the inward and outward customes from thence. By wch meanes yo ${ }^{r}$ highnes doubtfull frendes, or rather apparaunte enemyes, shall not only be made weake, and poore, but therw ${ }^{\text {th }}$ yo ${ }^{\boldsymbol{x}}$ selfe, and Realme, made strong and rich, both by sea, and lande, aswell there, as here. And where both is wrought vnder one, it bringeth a most happy conclusion.... By $w^{\text {ch }}$ meanes also yor $\mathrm{Ma}^{\text {tie }}$ shall ingraffe and glewe to yo ${ }^{\mathrm{r}}$ crowne, in effect all the Northerne, and Southerne viages of the world, so that none shalbe then well hable to crosse the seas, but subiect to $\mathrm{yo}^{\mathrm{r}}$ highnes devocion: considering the great increase of shipping that will growe, and be maynetayned by those long vyages, extending them selves so many sundrie wayes. And if I may perceave that yor highnes shall like of this enterprise, then will I most willinglie expresse my simple opinion, $w^{\text {ch }}$ waye the W. I. maye $w^{\text {th }}$ owt difficultie be more surprised, and defended, $w^{\text {th }}$ out $w^{\text {ch }}$ resolucion, it were but labour lost. But if yor Maty like to do it at all, then would I wish yor highnes to consider that delay doth often tymes prevent the perfourmaunce of good thinges : for the winges of mans life are plumed $w^{\text {th }}$ the feathers of death. And so submitting my self to $y^{r} M^{\text {ties }}$ favourable 
iudgement I cease to trouble yor highnes any further. Nouembris : 6.1577 .

$$
\begin{aligned}
& \mathrm{Yo}^{\mathrm{r}} \mathrm{Ma}^{\text {ties }} \text { most faithfull } \\
& \text { servaunt and subiect }
\end{aligned}
$$

[Signature (H. Gylberte) crossed through and hardly legible.]

[Not addressed.]

[Not endorsed.]

[The marginal heading is in the hand of one of Burghley's secretaries (see endorsement.)]

\section{APPENDIX B (p. 40 ante)}

(State Papers, Domestic, Elizabeth. Vol. clxxvii. No. 58.) [In Walsingham's hand]

A plotte for the anoyeng of the K. of Spayne.

The entrepryce is to svrpryce soche sphanyshe shippes as resorte yerely to the fyshing of the newe fownde lande and the grande baye.

For the execvtyon whereof yt shall be necessarye to have thre shyppes well furnished of 200 tonnes at the least.

The charges of the settyng owt of the sayd shyppes wyll amovnt vnto being thorrewghely manned and furnished the somme of

The tyme of proceading to the execvtyon of the entrepryce wyll bee abowt the ende of Aprell.

The benefyttes that wyll followe of the entrepryce.

The greatest shippes belongyng to the K. of Spaynes svbiectes shall be dystressed.

The nombre of his maryners $w^{\text {ch }}$ can not in many yeares bee svpplyed shall be dystressed.

They shall be pvt to great extremytye in Spayne for lacke of the svstentatyon of vyctvall that they receyve yerely by the sayd waye.

The benefyt that may be made of the shyppes tackle ordynaunce trayne oyle and fyshe wyll be woorthe at the least $40000^{\ddagger}$.

Necesserye consyderatyons.

$\mathrm{Yt}$ is fyrst to be consydered at whos charges the shippes shall 
be sett foorthe. Yf by her Matyo then may all the shyppes $w^{\text {th }}$ the fvrnitvre be bvrned and therby the K. of Spayne weakened as is before expressed. Yf by subiectes, then mvst they take the shyppes and ther ladyng and brynge the same eyther into this realme or into the lowe contryes to converte the benefyt therof to the destroyeng of ther charges yf they shoold be brought into this realme then woold the K. of Spayne repvte yt an open act of hostylytye a matter worthye of depe consyderatyon. To carrye them into the lowe contryes yt is dowbtfvll that they wyll not be receyved: for that yt woold cvt of the present fre traffycke the states have into Spayne.

The inconvenience lykely to insve

by the executyon of this plot.

The trafficke into Spayne wyll be cvtt of.

The K. wyll seeke to take reveng by sendyng men owt of the lowe contrye into Scotelande.

He wyll omytt no other revenge that he may take by procvring trobles in her maties owne realme.

To meet with these inconveniences.

1. The K, of Fravnces mynde is to be felt towching an assocyatyon for the annoyeng of the $K$. of Spayne and the abrydging of his greatnes.

2. Scotelande is to be assvred.

The entrepryce for the Indias is to be performed.

[Not signed.]

[Not addressed.]

[Endorsed in the hand of / A plott for the annoying of Walsingham's secretary:] $\}$ the K. of Spain.

[Calendar dates this paper as :]-? March 1585.

\section{APPENDIX C (p. 4 I ante)}

(State Papers, Domestic, Elizabeth. Vol. clxxxiii. No. 13.)

After $o^{r}$ hartye commendacions whereas vppon knowledge receauid here of a generall arrest made in Spayne of dyuers of her Maties subiectes shippes and goodes, yt was of late thought 
meete by her Maty to direct $S^{r}$ Walter Rawleghe Knight to set fourth certen shippes to the seas out of the west partes of this realm, for th'intercepting of such of the K: of Spaynes subiectes as should repeire to the fishinge at New found land, $w^{\text {ch }}$ the said shippes have accordingly executed $\mathrm{w}^{\text {th }}$ so good successe as to bringe into this realm a good number of Spanish vessells taken by them at the said fishinge, wherein there are by estimacion about sixe hundreth maryners, and forasmuch as we are credibly aduertised that her maties subiectes yet stayd in Spayne, by vertue of the said generall arrest, are nowe of late vsed there in verie hard and vnsufferable sorte, we do therfore thincke meete, that where the said Spanishe maryners are nowe as we vnderstand dyetid at three shillinges and fower pence a man by the weeke, their said dyet should hereafter be ratid but at three pence a man by the daye, the chardges whereof are to be allowid out of the third part of the fishe to be by you allotid vnto the vittallers of the said shippes of warre, $\mathrm{w}^{\text {th }}$ thother two third partes, one to the owners and the other to the maryners of the same. All $w^{\text {ch }}$ fishe we thincke meete should be sould ether $w^{b}{ }^{b}$ in the realm or in forren countryes that are in league or good amitye $w^{\text {th }}$ her $\mathrm{Ma}^{\text {ty }}$, where $y t$ may be vtterid to most proffit. In the doing wherof, we praye you to caule three of the Commissioners of the Admiralty there to $\mathrm{yo}^{\mathrm{r}}$ assistaunce, by whos aduice and trauell theis thinges may accordinglye be put the better in execucion. And so we bid you hartelye fare well. At Richmond the $\mathrm{X}^{\text {th }}$ of October 1585.

Yor very lovinge frendes

[Not signed.]

[At the foot of the page is written in the hand of one of Burghley's secretaries:-] $\mathrm{S}^{\mathrm{r}}$ John Gilbert Knighte.

[Not addressed.]

[Endorsed in the hand of

I 585 .

Burghley's secretary:-

Io. Oct.

M: To $\mathrm{S}^{r}$ Io: Gilbert. 


\section{APPENDIX D (pp. 4I, 43 ante)}

(Additional MSS. in the British Museum Library 12505 , folio 477.)

A brieffe platforme for a voyadge with three ships unto the Iland of Ramea in Canada where I purpose god willinge to leave inhabitaunts (accordinge to my intente the laste yeare) which shall keepe the Iland to her Maiesties use as also fforbid the ffrenchmen from the trade of ffishinge in that place who this laste yeare by force (as havinge firste possession of the harboroughes) did expell myselffe and others her highnes subiects from the said Iland.

The Iland of Ramea is about 16 leagues in length scituated within the Bay of Cannada and lyeth from the south lyne but 47 degrees or lesse yeat is yt much colder then in England The soyle is sandy and seemeth exceedinge good for tylladge yt yealdeth naturally wild corne lyke barly allso peasse strawberies goosberies mulberies and wild roses.

Of wood there is overmuch plenty the most pte wherof ar firr trees and birch, within the land there runneth which I did see on faire ryver of ffreshe water replenyshed as I was informed with severall sorts of ffreshwater fishe, about this said Iland there is abonndaunte plenty of codd, and for the refudge of ships two good harbours on wherof may be strongly ffortified with few men by meanes of a very smale Iland which lyeth in the mouth therof, upon which 20 . men beinge entrenched they may without daunger defend them selves from .500 . and lykewyse with ordinaunce and musketts from their forte may easily commaund the whole harborough.

In the other harbour about .3. leagues in distaunce from the fformer I know not what meanes of fortification there is and therefore purposse (for the more securytie yf god pmytt with the helpe of my friends who have pmysed the furtheraunce hereof) to send thither three good ships well ffurnished to be there yf possible $\cdot 30$. daies before any ffrenchmen use to come and to fortifie this other harborough allso both by sea and land as we shall see most meete, which don such as ar apoynted to remayne in the contrie shall presently betake them selves to tilledge plantinge and buyldinge, and the rest to be imployed in fishinge for the speedy ladinge and retorne of the ships. 
Now wheras the fishinge in this Iland is alwayes sooner ended by 40 . or .50 . dayes then in other places by which meanes the ships in retorninge may with smale preiudice and lyttle losse of tyme view all the harboroughes alonge the coaste of cape Brytton and so from thence in the south pte of Newfoundland, where yf so yt stand with her highnes pleasure and the good lykinge allso of the lords of the Counsell very sufficiente service (thorough god his pvidence) may be pformed againste such ships of Bayon St $\mathrm{Jn}^{\circ}$ de lus and Ciborrow in Ffraunce (which ar aparauntly knowne every yeare from those pts to serue the Kinge of Spaigne with ffishe) to the greate preiudice of the Kinge of Spaigne, who were not able to maynteine his ships at sea yf he were not supported by theise fishermen.

FFurther as towchinge the inhabytinge in the said Iland and the contries thereabouts in few yeares yt may be effected to the peaceable continuaunce of the inhabitaunts only by keepinge the commaund of the chieffeste harbours in those contries, by which meanes all other nations wilbe discoraged in shorte tyme and wholly worne out of that trade, then shall the inhabitaunts without resistaunce enioy all the fishinge in the Bay which is as yeat an unknowne benefitt, as allso have the whole trade of all the inland contries only in their owne hands.

by this meanes her maiesties revenues and dominions may in shorte tyme be greatly enlarged to her endless honor in all posteryties which the lord of heaven graunte yf yt be his will.

London. this 4 th of October 1597.

by me Charles Leigh.

\section{APPENDIX E (pp. 53, 54 ante)}

\section{(State Papers, Colonial. Vol. i. No. 9.)}

Yt beinge a verrey noble action to inlarge a dominion, wheath ${ }^{r}$ yt be by open conquest, wheare resistance is made or by plantinge vpon plases neclected thoroughe the barbarousnes of the inhabitants or neyghbors the most vertuous minds are easly taken $\mathrm{w}^{\text {th }}$ falseste hopes $;. .$. th $^{\text {r }}$ fore in this preposition of plantinge an Englishe collonee in the northe weste of Amerrica: ... the difficulties should be examined,... and as itt is to bee 
wishte, that wee had plases of $o^{r}$ owne to furnishe soe necessary a comoditye as apertinenttes to $o^{r}$ shippinge soe muste yt be examined, wheath ${ }^{r} o^{r}$ country should not bee as muche wrested or more to recouer them thence then by the wayes they haue them; \& to the argument that God foresawe or necessities to come of those provisions \& therfore discouered to Henry the $7^{\text {th }}$ thes cuntries, yt weare to be answered ... thatt soe longe as a state resists the sword \& cane furnishe mony or oth ${ }^{\mathbf{r}}$ matter for exchange, trafficke will bringe the enemies moste forbidden comodity in sufficiently, soe as yf the only benefitt weare the havinge a land from whence to fetche things necessary for our shippinge, yt weare like to bee baughte to deere, since $w^{\text {th }}$ the bringinge in of those trades from the easte, wee carry out our aboundinge commodities to the inrichinge of $o^{r}$ state $w^{\text {ch }}$ is sayde should likewyse bee downe this way, in tow kindes, one by trafficke $\mathrm{w}^{\text {th }}$ those nations that come theth ${ }^{\mathrm{r}}$ for fishe, $\&$ then ouer land, both $\mathrm{w}^{\mathrm{ch}}$ wayes require much tyme to bringe them to a ripenes.

$\&$ in the trade ouer land theare riseth many difficulties, ... the trafficke to muscouia, is a hevey iorney to $o^{r}$ marchants, in respecte of the lengthe of the voyage $\&$ couldnes of the region $w^{\text {ch }}$ suffers butt one voyage in a yeare....

$\&$ from hence lett vs conclude thatt anoth ${ }^{\mathfrak{r}}$ trade weare more convenient for vs \& that this of new found land for the shortenes of the passage \& openesse of the sea, \& lesse intemperate could then muscouia, havinge the commodities necessary for shippinge $\&$ trade settled there is more convenient, admittinge the necessities for owre navye to be theare in abundance lett vs examine how a trade may be settled there \& whatt may bee the difficulties in ther trade as well as in the settlinge; whearin wee muste somethinge examine the nature of the cuntrey, $w^{\text {th }}$ the state $\&$ inclinacion of $o^{r}$ people, \& the correspondansye of that contry $w^{\text {th }}$ oth $^{\mathbf{r}}$ new discoueries, peopled $w^{\text {ch }}$ peradventure att the first aprehension makes this worke seeme the easier.

The contrye seemes by the preposicion to bee cowlde, \& to bringe forthe commodities as coulde cuntries doth $w^{\text {th }}$ industery $\mathrm{o}^{\mathrm{r}}$ contry people, havinge euer bine bred $w^{\text {th }}$ plenty in a more temperate ayre, and naturally not verry industrious att home and lesse to seeke out plases, wheare thr ${ }^{\mathrm{r}}$ labo $^{\mathrm{rs}}$ are present and 
ther hopes a littell differed, wheareof wee have too good experience by Ireland, $w^{\text {ch }}$ being neere $v s$, a temperate \& fertile contrye, subiecte to our owne lawes and halfe sivill, the porttes and many plases freindly inhabited, notw ${ }^{\text {tb }}$ standinge many of good reputacion, became vndertakers there in the tyme of pease, coulde not invite our people, neyther in any compotent numbers, nor constantly in th ${ }^{\mathrm{r}}$ action....

The generall discouery beinge made, a particuler discouery is to bee made, of the plase wheare $o^{r}$ nation should settle, yf there bee hope eyther of mines or oth ${ }^{r}$ good returne thatt may draw one a secondinge of the action, $w^{\text {ch }}$ is moste to bee doubted; for yf her $\mathrm{Ma}^{\text {tie }}$ shall only countenaunce yt and recommend yt to her marchanttes whoe may haue for incorragm ${ }^{t}$ the difficultie of the esterne trade \& a gratious junction of the trafficke of america to bee only reserued to the firste adventures, yett when soe great a charge muste be firste issued as the sendinge of a compotent nomber to inhabite, $w^{\text {th }}$ all necessaries requisitt for new inhabitants, and victualles for a hole yeare for them, \& that th ${ }^{r}$ retorne shall bringe home nothinge aboue the ordinarye freght of fish and a narration of the sighte of a cuntrey and hope of better by the nexte adventure, yt is feared that the ordinary wayes of traed, beinge lesse cheargeable, they will content them selues \& looke vpon the dangers and allteracions a farr of, and eyther slowlye or not all giue second ; and wheare $y t$ is prepounded that $o^{\mathbf{r}}$ poore of England, may be easly sent theth $^{r}$, by the shippes that goe to fishe yearely they beinge deliuered at the porttes, $w^{\text {th }}$ victualles for a yeere, $o^{r}$ common people of England are not riche, \& doe almoste repine att those most behouefull impositions $w^{\text {ch }}$ are layed vpon them, for leveinge of souldiers \& yett those willinge subsidies and payments they graunt to her $\mathrm{Ma}^{\text {tie }}$ for juste reasons deputed in open parliment, then wee muste remember whatt pore they are thatt arre requisite to people a new conqueste, not the inpotente...

And this may well bee lookte for, thatt the inhabitants, will give vs noe better way then wee can forse, \& will easly insulte vpon $o^{r}$ weakenes yf they can find an advantage, besides wee are to conseaue, thatt the frenche whoe haue pretenses, $\&$ haue a secreat trafficke theth ${ }^{r}$, will repine $\&$ resiste yf they can or dare, all vnder the subiection of the spaniardes are declared 
oposittes, \& we muste resolue that the kinge $\&$ that state will have his eyes open vpon ower actions, \& will yf hee cane forse vs from any benifite. ...

Now thorrowe all these difficulties, yf the prinse would assiste yt in parte \& her marchants thatt are well affected goe liberallye into yt, \& that the cuntries mighte bee stirred to an assistance by men in some meaute measure, \& some gentelmen moued to bee venturers, thatt should foresee not only the vndertakinge butt the secondinge, then I conseaue, that a worthye generall beinge chosen, thatt mighte haue a royall commission, \& weare quallifide to judge of the sighte of plases for strengthe, \& for comodities, would exercise justice in the - to the presise the marchaunts adventurers \& gentelmen or others thatt should th $^{\mathrm{r}}$ persone would keepe his troopes in obedience, and in industrye, and vse clemensey \& justice to the inhabitinge, yt mighte bee a glorious action, for $o^{x}$ prinse and cuntrie, honorable for the general and adventurers and in tyme profitable, to the generall and particular, \& I doubte not an acceptable service to God....

[Not addressed.]

[Not signed.]

[Endorsed:-] Plantacion in America.

[This is evidently a copy, and the lines represent words which the copyist could not read. A few spaces are filled and obvionsly wrong words corrected, in the earlier part, in the hand of Sir Edward Conway, as stated in the calendar.]

[Calendared as] ? 1600.

\title{
APPENDIX F
}

\section{THE ATLANTIC FISHERIES ARBITRATION}

\author{
Award of the Hague Tribunal as Published \\ SePtember 8, igio.
}

\section{QUESTION I.}

Must any reasonable regulations made by Great Britain, Canada, and Newfoundland in the form of municipal laws, ordinances, or rules-(such regulations being $(a)$ appropriate or necessary for the preservation of the fisheries ; $(b)$ desirable on 
grounds of public order and morals; $(c)$ equitable and fair as between local fishermen and the inhabitants of the United States)-be subject to the consent of the United States?

The Tribunal decides and awards as follows:-

The right of Great Britain to make regulations without the consent of the United States, as to the exercise of the liberty to take fish referred to in Article I of the Treaty of October 20, 1818 , in the form of municipal laws, ordinances, or rules of Great Britain, Canada, or Newfoundland, is inherent to the sovereignty of Great Britain.

The exercise of that right by Great Britain is, however, limited by the said Treaty in respect of the said liberties therein granted to the inhabitants of the United States in that such regulations must be made bona fide and must not be in violation of the said Treaty.

Regulations which are (1) appropriate or necessary for the protection and preservation of such fisheries, or (2) desirable or necessary on grounds of public order and morals without unnecessarily interfering with the fishery itself, and in both cases equitable and fair as between local and American fishermen, and not so framed as to give unfairly an advantage to the former over the latter class, are not inconsistent with the obligation to execute the Treaty in good faith, and are therefore reasonable and not in violation of the Treaty.

For the decision of the question whether a regulation is or is not reasonable, as being or not in accordance with the dispositions of the Treaty and not in violation thereof, the Treaty of 1818 contains no special provision. The settlement of differences in this respect that might arise thereafter was left to the ordinary means of diplomatic intercourse. By reason, however, of the form in which Question I is put, and by further reason of the admission of Great Britain by her counsel before this Tribunal that it is not now for either of the parties to the Treaty to determine the reasonableness of any regulation made by Great Britain, Canada, or Newfoundland, the reasonableness of any such regulation, if contested, must be decided, not by either of the parties, but by an impartial authority in accordance with the principles hereinabove laid down, and in the manner proposed in the recommendations made by the Tribunal in virtue of Article IV of the Agreement. 
The Tribunal further decides that Article IV of the Agreement is, as stated by counsel of the respective parties at the argument, permanent in its effect, and not terminable by the expiration of the General Arbitration Treaty of 1908, between Great Britain and the United States.

In execution, therefore, of the responsibilities imposed upon this Tribunal in regard to Articles II, III, and IV of the Special Agreement, we hereby pronounce in their regard as follows :-

\section{AS TO ARTICLE II.}

Pursuant to the provisions of this Article, either party has called the attention of this Tribunal to acts of the other claimed to be inconsistent with the true interpretation of the Treaty of 1818 .

But in response to a request from the Tribunal ... for an exposition of the grounds of such objections, the parties replied ... to the following effect:-

His Majesty's Government considered that it would be unnecessary to call upon the Tribunal for an opinion under the second clause of Article II in regard to the executive act of the United States of America in sending warships to the territorial waters in question, in view of the recognized motives of the United States of America in taking this action and of the relations maintained by their representatives with the local authorities. And this being the sole act to which the attention of this Tribunal has been called by his Majesty's Government, no further action in their behalf is required from this Tribunal under Article II.

The United States of America presented a statement in which their claim that specific provisions of certain legislative and executive acts of the Governments of Canada and Newfoundland were inconsistent with the true interpretation of the Treaty of 1818 was based on the contention that these provisions were not 'reasonable' within the meaning of Question I.

After calling upon this Tribunal to express an opinion on these acts, ... the United States of America pointed out in that statement that under Article III any question regarding the reasonableness of any regulation might be referred by the Tribunal to a Commission of expert specialists, and expressed an intention of asking for such reference under certain circumstances.

The Tribunal .... is of opinion that the decision on the reasonableness of these regulations requires expert information about the fisheries themselves and an examination of the practical effect of a great number of these provisions in relation to the conditions surrounding the exercise of the liberty of 
fishery enjoyed by the inhabitants of the United States, as contemplated by Article III. No further action on behalf of the United States is, therefore, required from this Tribunal under Article II.

\section{As to ARTICLE III.}

As provided in Article III, ...' any question regarding the reasonableness of any regulation, or otherwise, which requires an examination of the practical effect of any provisions surrounding the exercise of the liberty of fishery enjoyed by the inhabitants of the United States, or which requires expert information about the fisheries themselves, may be referred by this Tribunal to a Commission of expert specialists; one to be designated by each of the parties hereto, and the third, who shall not be a national of either party, to be designated by the Tribunal.'

The Tribunal now, therefore, calls upon the parties to designate within one month their national Commissioners for the expert examination of the questions submitted.

As the third non-national Commissioner this Tribunal designates Dr. P. P. C. Hoek. ...

After a reasonable time, to be agreed on by the parties, for the expert Commission to arrive at a conclusion, by conference, or, if necessary, by local inspection, the Tribunal shall, if convoked by the President at the request of either party, thereupon, at the earliest convenient date, re-convene to consider the report of the Commission, and if it be on the whole unanimous shall incorporate it in the award. If not on the whole unanimousi.e. on all points which in the opinion of the Tribunal are of essential importance-the Tribunal shall make its award as to the regulations concerned after consideration of the conclusions of the expert Commissioners and after hearing argument by counsel.

But while recognizing its responsibilities to meet the obligations imposed on it under Article III, .... the Tribunal hereby recommends as an alternative to having recourse to a reconvention of this Tribunal that the parties should accept the unanimous opinion of the Commission or the opinion of the non-national Commissioner on any points in dispute as an arbitral award rendered under the provisions of Chapter IV of The Hague Convention of 1907.

\section{AS TO ARTICLE IV.}

Pursuant to the provisions of this Article, hereinbefore cited this Tribunal recommends for the consideration of the Parties the following rules and method of procedure under which all questions which may arise in the future regarding the exercise of the liberties above referred to may be determined in accordance with the principles laid down in this award. 
I.

All future municipal laws, ordinances, or rules for the regulation of the fishery by Great Britain in respect of (I) the hours, days, or seasons when fish may be taken on the Treaty coasts; (2) the method, means, and implements used in the taking of fish or in carrying on fishing operations; (3) any other regulation of a similar character shall be published in the London Gazette two months before going into operation.

Similar regulations by Canada or Newfoundland shall be similarly published in the Canada Gazette and the Nerefoundland Gazette respectively.

2.

If the Government of the United States considers any such laws or regulations inconsistent with the Treaty of 1818 , it is entitled to so notify the Government of Great Britain within the two months referred to in Rule No. I.

3.

Any law or regulation so notified shall not come into effect with respect to inhabitants of the United States until the Permanent Mixed Fishery Commission has decided that the regulation is reasonable within the meaning of this award.

4 .

Permanent Mixed Fishery Commissions for Canada and Newfoundland respectively shall be established for the decision of such questions as to the reasonableness of future regulations, as contemplated by Article IV of the Special Agreement; these Commissions shall consist of an expert national appointed by either party for five years. The third member shall not be a national of either party; he shall be nominated for five years by agreement of the parties, or, failing such agreement within two months, he shall be nominated by her Majesty the Queen of the Netherlands. The two national members shall be convoked by the Government of Great Britain within one month from the date of notification by the Government of the United States.

5.

The two national members having failed to agree within one month, within another month the full Commission, under the presidency of the Umpire, is to be convoked by Great Britain. It must deliver its decision, if the two Governments do not agree otherwise, at the latest in three months. The Umpire shall conduct the procedure in accordance with that provided in Chapter IV of the Convention for the Pacific Settlement of International Disputes, except in so far as herein otherwise provided. 
6.

The form of convocation of the Commission ... shall be ....

7.

The unanimous decision of the two National Commissioners, or the majority decision of the Umpire and one Commissioner, shall be final and binding.

\section{QUESTION II.}

Have the inhabitants of the United States, while exercising the liberty to take fish on the Treaty coasts, referred to in the first Article of the Treaty of 1818 , a right to employ, as members of the fishing crews of their vessels, persons not inhabitants of the United States?

The Tribunal is of opinion that the inhabitants of the United States while exercising the liberties referred to in the said Article have a right to employ, as members of the fishing crews of their vessels, persons not inhabitants of the United States.

But in view of the preceding considerations, the Tribunal, to prevent any misunderstanding as to the effect of its award, expresses the opinion that non-inhabitants employed as members of the fishing crews of United States vessels derive no benefit or immunity from the Treaty; and it is so decided and awarded.

\section{QUESTION III.}

Can the liberties to 'take fish' and to 'dry and cure fish' in the places referred to in the Treaty be subjected, without the consent of the United States, to the requirements of entry or report at Custom Houses or the payment of light or harbour or other dues, or to any similar condition?

The Tribunal decides and awards as follows:-

The requirement that an American fishing vessel should report, if proper conveniences for doing so are at hand, is not unreasonable, for the reasons stated in the foregoing opinion. There should be no such requirement, however, unless there be reasonably convenient opportunity afforded to report in person or by telegraph, either at a Custom House or to a Customs official. 
But the exercise of the fishing liberty by the inhabitants of the United States should not be subjected to the purely commercial formalities of report, entry, and clearance at a Custom House, nor to light, harbour, or other dues not imposed upon Newfoundland fishermen.

\section{QUESTION IV.}

Can restrictions be imposed upon American fishermen making the exercise of the privileges granted them by the Treaty to enter certain bays or harbours for shelter, repairs, wood, and water conditional upon the payment of light, or harbour, or other dues, or entering or reporting at Custom Houses, or any similar conditions?

It is decided and awarded that such restrictions are not permissible.

It seems reasonable, however, in order that these privileges accorded by Great Britain on these grounds of hospitality and humanity should not be abused, that the American fishermen entering such bays for any of the four purposes aforesaid and remaining more than 48 hours therein, should be required, if thought necessary by Great Britain or the Colonial Government, to report, either in person or by telegraph, at a Custom House or to a Customs official, if reasonably convenient opportunity therefore is afforded.

And it is so decided and awarded.

\section{QUESTION V.}

What is a 'bay' within the meaning of the Treaty?

The Tribunal decides and awards :-

In case of bays three marine miles are to be measured from a straight line drawn across the body of water at the place where it ceases to have the configuration and characteristics of a bay. At all other places the three marine miles are to be measured following the sinuosities of the coast.

Considering that the Tribunal cannot overlook that this answer to Question V, although correct in principle and the only one possible in view of the want of a sufficient basis for a more concrete answer, is not entirely satisfactory as to its practical applicability, and that it leaves room for doubts and differences in practice; therefore the Tribunal considers it its duty to 
render the decision more practicable and to remove the danger of future differences by adjoining to it a recommendation in virtue of the responsibilities imposed by Article IV of the Special Agreement.

Considering, moreover, that in treaties with France, with the North German Confederation and the German Empire, and likewise in the North Sea Convention, Great Britain has adopted for similar cases the rule that only bays of ten miles' width should be considered as those wherein the fishing is reserved to nationals; and that in the course of the negotiations between Great Britain and the United States a similar rule has been on various occasions proposed and adopted by Great Britain in instructions to the naval officers stationed on these coasts; and that, though these circumstances are not sufficient to constitute this a principle of international law, it seems reasonable to propose this rule with certain exceptions, all the more that this rule with such exceptions has already formed the basis of an agreement between the two Powers,

Now, therefore, this Tribunal, in pursuance of the provisions of Article IV, hereby recommends for the consideration and acceptance of the High Contracting Parties the following rules and method of procedure for determining the limits of the bays hereinbefore enumerated :-

I. In every bay not hereinafter specifically provided for the limits of exclusion shall be drawn three miles seaward from a straight line across the bay in the part nearest the entrance at the first point where the width does not exceed ten miles.

2. In the following bays, where the configuration of the coast and the local climatic conditions are such that when foreign fishermen, when within the geographic headlands, might reasonably and bona fide believe themselves on the high seas, the limits of exclusion shall be drawn in each case between the headlands hereinafter specified as being those at and within which such fishermen might be reasonably expected to recognize the bay under average conditions. ...

For Fortune Bay, in Newfoundland, the line from Connaigre Head to the Light on the South-Easterly end of Brunet Island, thence to Fortune Head.

For or near the following bays the limits of exclusion shall be three marine miles seawards from the following lines, namely-

... At Placentia Bay, in Newfoundland, the line from Latine Point, on the Eastern mainland shore, to the most Southerly Point of Red Island, thence by the most Southerly Point of Merasheen Island to the mainland.... 
It is understood that nothing in these rules refers... to Conception Bay, which was provided for by the decision of the Privy Council in the case of the Direct United States Cable Company $\%$ the Anglo-American Telegraph Company, in which decision the United States have acquiesced.

\section{QUESTION VI.}

Does the Treaty give the inhabitants of the United States the same liberty to take fish in the bays, harbours, and creeks of Newfoundland as it does in the bays, harbours, and creeks of Labrador?

The Tribunal is of opinion that American inhabitants are entitled to fish in the bays, creeks, and harbours of the Treaty coasts of Newfoundland and the Magdalen Islands, and it is so decided and awarded.

\section{QUESTION VII.}

Are the inhabitants of the United States whose vessels resort to the Treaty coasts for the purpose of exercising the liberties referred to in Article I of the Treaty entitled to have for those vessels, when daly authorized by the United States in that behalf, the commercial privileges on the Treaty coasts accorded by agreement or otherwise to United States trading vessels generally?

The Tribunal is of opinion that the inhabitants of the United States are so entitled in so far as concerns this Treaty, there being nothing in its provisions to disentitle them, provided the Treaty liberty of fishing and the commercial privileges are not exercised concurrently, and it is so decided and awarded.

The document is signed by the five arbitrators - Dr. Lammasch, Dr. de Savornin Lohman, Judge George Gray, Sir Charles Fitzpatrick, and Dr. Drago. Dr. Drago, however, states his dissent from the majority of the Tribunal in respect to the considerations and enacting part of the Award as to Question V.

\section{OTHER RECOMMENDATIONS.}

In regard to the opinions of the Tribunal accompanying the decisions, the following with reference to Question III are of special interest :-

The Tribunal is of opinion that light and harbour dues, if not imposed on Newfoundland fishermen, should not be imposed on American fishermen while exercising the liberty granted by the 
Treaty. To impose such dues on American fishermen only would constitute an unfair discrimination between them and Newfoundland fishermen and one inconsistent with the liberty granted to American fishermen to take fish, \&c., ' in common with the subjects of his Britannic Majesty.'

Further the Tribunal considers that the fulfilment of the requirement as to report by fishing vessels on arrival at the fishery would be greatly facilitated in the interest of both parties by the adoption of a system of registration and distinctive marking of the fishing-boats of both parties analogous to that established by Articles V to XIII....

Note.-Dots in the above appendices represent irrelevant matters, which I have omitted. 


\section{INDEX}

Africans, 6, 1 39, 140.

Agricultural Society, I 72 .

Agriculture, 58, 6I, $125,5^{1-2}$, I 72-3, I 75, 182-4. See Cattle, Horses, Pasture Land.

Aldworth, Thomas, 38, 54 .

Alexander, E., 219.

Alexander, Mr., 234.

Alexander VI, Pope, 7 .

Alexander, Sir William, 48, 49, $6_{2}, 6_{3}, 6_{4}, 6_{7}-8$.

Alexandria, 6,8 .

Allery, J., 219.

Alphonso V, 6 .

Amherst, Colonel W., 128.

Amiens, Treaty of, 130.

Anchor Point, 215 .

Anglo-Newfoundland Development Company, I79 et seq.

Anguille, Cape, 175.

Anne, Queen, Jo\%.

Anspach, Rev. L. A., I5 I.

Anstruther, Captain R. H., 234.

Anticosti Island, 23, 143, I45, I $46-7$.

Antilia, 6.

Aquafort, 16, 64, 83 .

Arundel, Thomas Earl of, 34, 47.

Ashurst, I 5.

Aston, Sir A., 62, 63.

Andierne, 87.

Avalon, Colony of, 6r, 64, 76 .

Avalon, Peninsula of, $55,1_{40}$, I59, I68, 169, I75.

Azores, 7, 14, I6, 8 .

Bacalhaos, 22, 23.

Baccalieu Island, 16,57 .

Bacon, Francis Lord, 54, 56, 60.

Baffin Bay, 2 I.

Baffin, William, 20, 2 I.

Baillie-Hamilton, Governor, 211.

Balaena, 236.
Baltimore, Lord, see Calvert.

Banks or Grand Banks of Newfoundland visited by:

Americans, 197-8, 226.

Englishmen, II 7 , II 8 , I47-8, 197.

Frenchmen, 25, 26, 29, 197-8, 210.

Newfoundland included, 39 .

Newfoundlanders, 197, 199, 200, 207.

Portuguese, 25, 26, 29, 82 .

Spaniards, 82, 197 .

West Indians, I 39 , I 40.

Bannerman, Sir A., I88.

Barnstaple, 92, 118, 126, 138 .

Basques, French and Spanish, 26 $-7,28,30,82$.

Basques, French, 4I, 43 n., 87, I 5, I 32, 216, 250.

Basques, Port-aux-, I 25, I 32, 160 , I $78,180$.

Battle Harbour, 201.

Bay Bulls :

fortified, 70 .

population, 83 .

raided, $79,90,91-2,128,136$.

Bay of Islands :

agriculture at, $\mathbf{I} 75$.

Anglo-American disputes at, 233-4.

Anglo-French disputes at, 219.

Colonization of, 166-7, 21 4.

Cook at, I33, 140.

French at, 28,132 .

herring at, 215,233 .

Micmacs at, 166 et seq.

Nova Scotians at, 22 I, 233.

Point Rich and, 133 .

Bayard, T. F., 232.

Beauclerk, Lord Vere, 104, I12, I $20,148$.

Beaudoin, Abbé Jean, 93. 
Belfast, ${ }^{1} 3^{8}$.

Bell Isle, I8r.

Belle Isle, I 74 .

Belle Isle Strait :

American rights in, 135 .

English Colonization in, I43-5, 215.

English rights in, 55, 69, 228.

French in, 22-3, 88, I $31-2,233$.

Mountains, 174 .

raided, 136 .

railways and, $18 \mathrm{I}$.

Bermuda, I 39, I 40.

Berry, Admiral Sir John, 82.

Betts Cove, 180.

Bideford, I 18, I26, I38.

Bjarni, $3,4$.

Blaine, J. G., 232.

Blanc Sablon, 22, 144, I47.

Boboy (Beaux Bois?), I 24 .

Bodin, Jean, 48, 49, 5 I.

Bonavista :

commandants, 98, 99, 106 .

population, 83,94 .

raided, $93,99$.

Bonavista Bay:

agriculture in, 173 .

English colonize, 55, 61, 64, 96, $106,121-2,133,167$.

inland routes to, $167-8$.

lumbering in, 176 .

seals in, 121 .

Bonavista Cape :

boundary, $55,67,72,77,83$, 96-7, IOI, I IO.

French visit, 22-3, 30 .

hunting at, 84 .

pasture land at, 67 .

Portuguese visit, 16.

Treaties and, 106, I 29, I 33 .

Bond, Sir Robert, 232.

Bonne Bay colony, 14I, 167, 21 5, 2 I 9 et seq.

discovered, $\mathbf{I} 32$.

electoral district, 185 .

Micmacs, $167-8$.

Bonnycastle, Sir Richard, 197.

Bowler, Captain Robert, R.N., I 22.

Boys Island, 1 27-8.

Bradley, Thomas, 12.

Bradore Bay, 29, 132, $145,147$.
Brady, Major, $15 \mathrm{I}$.

Brazil, I 5, 205, 22.

Brazil (legendary), 6 .

Brehats, Havre des, 2 I 5.

Brest, 22, 25, 28, 29.

Bretons, 19, 25, I 3I-2, 216-7, 225.

Bridge, Captain, R.N., I00, IoI, 105.

Brigus, I 7I, I 72.

The Brilliant, 234.

Bristol :

Discovery of Newfoundland by, 9, II, I 5, I9, 47.

Discovery of Hudson Bay by, $2 \mathrm{I}, 46$.

Gilbert's colony and, $3^{6}, 3^{8}$.

Guy's colony and, 54, 56-8, 213 .

Labrador and, I 43 .

Newfoundland and, 205.

Bristol's Hope, 56, 58 .

Briton or Britton Bay or Harbour, $88,213$.

Broad Cove, 185 .

Brooks, Nathaniel, I 15.

Broyle, Cape, 16, 62.

Buchan, Captain David, R.N., I42, I56.

Bull's Arm, 93.

Burgeo, 164, 185, 21 3, 214, 237.

Burin, 87, I 24, 210, 21 4, 237.

Burleigh, William Cecil Lord, 36 .

Burnt Islets, 2 I 3.

Burwell, Port, 203.

Button, Thomas, 20, 21.

Bylot, Robert, 20, 21 .

Byng, Admiral John, II6, I 20.

Byron, Admiral John, I3I.

Cabot, John, 8-I4, 22, 24, 34, 38, 193.

Cabot, Sebastian, I3, I4, 22.

Cabot Strait, 23, 55, 163, 228.

Calvert, Cecil, Lord Baltimore, $62,70,76$.

Calvert, George, Lord Baltimore, $34,59,6$ I-3 $64,78,80$.

Canada:

Americans and Canadians, 226.

Boundary, $143,147$.

Capitalists of, $176,178-81,189-$ 90, 233-4. 
Canada-continued.

Confederation with, 189,22 r .

exports to, 205, 214.

geology of, $160-1$.

imports from, I $39,155,184$, 205.

Labrador and French Canadians, 144, $146-7$.

Newfoundland a steppingstone to or part of, $23,28,50-2,79-$ 8o, 87 .

Nova Scotia and Newfoundland, I 23 et seq., 148, 163, 200.

Nova Scotians and West Coast, 2 I 5,22 I et seq.

Treaties and, 2 I I -1 2, $228-9$.

Canada Bay, ror.

Canuing, J., 2 so.

Cape Breton, 19, 25.

Cape Breton Island :

hunters, \&c., from Ingonish, 125 , 132.

Jerseymen at, I 44 .

Micmacs from, 163. See Micmacs.

Newfoundland overlapped, 39 .

settlers from, $125,1_{32}, 137$.

settlers of Placentia go to, I 24 et seq., I48. See Placentia.

steppingstone to Newfoundland, $19,43,128,250$.

Caprouge, Ior, 2 I 6.

Carbonear, $83,94,98$, ro6, I' I, I $72,188,200,2$ I 6.

roads of, I 7 I, 188 .

Carbonear Island, 93, 94, 99, 105, I 2 7, 128.

Carleill, Christopher, 20, 36.

Carson, Dr. W., 157, 172.

Carter, John, I 2.

Cartier, Jacques, 2 I, 22-4, 25.

Cartwright, $20_{3}$.

Cartwright, Captain George, I4I2, I 43-4, I46, I 59.

Cartwright, Lieutenant John, R.N., I 4 I-2, I 59.

Cary, Henry, Lord Falkland, 59, 60-I.

Catalina Harbour, 30.

Cattle, \&c., 4, 57, 62, 83, 123, I $72-3,183,222$.

Chamberlain, Joseph, 232.

Chapeau Rouge, $87,124$.
Chappell, Lieutenant E., R.N., 209, 2 I $5,22 \mathrm{r}$.

Charles I, 46, 63, 70 .

Charles II, 49.

Charles Cape, I43.

Charles Harbour, 143-4.

Charlevoix, P. F. X. de, 93 .

Château Bay, r9, r43, r46.

Chidleigh or Chudleigh, Cape, 20I, 203.

Child, Sir Josiah, 49.

Chimmo, Fort, 202, 203.

Churches, 39, 57, 62, 98, I 5 r, r 86 et seq.

Cleasby, Captain Thomas, R.N., 92.

Clinton, Captain, R.N., I 20, I 21.

Cochrane, Admiral Sir Thomas J., I 7 , I73, I84.

Codroy Island, 214.

Codroy rivers, 175 .

Colbert, Jean Baptiste, 50, 51, 52.

Collins, John, 105, 106, I I 5 , 117 , I 50.

Colston, William, 57, 58.

Columbus, Christopher, 6-9, 10.

Conception Bay, I4, 16, 30, 26 I.

business centre in, 205 .

colonies in, $5^{6}$ et seq., 67,96 , $2 \mathrm{I} 3$.

defences in, 100.

disputes in, 227.

raided, $93,99$.

starting-place for the North, I45, 201, 205,2 I6.

See Carbonear, Cuper's Cove, Harbour Grace, \&c.

Conception Cape, 16.

Conche, IOI, 2 I 6.

Connaigre, 88, 1 $25,260$.

Conne Bay and River, 164, 165, I79.

Convicts, see Felons.

Conway, Edward, Viscount, 63, 253.

Cook, Captain James, R.N., I33, I 40.

Cork, 138 .

Cormack, W. E., I43, I59-70.

Cornwall, 36, 67, \&c. :

See Falmouth, Fowey, Gweek, Mevagissey, St. Loo.

Cortereal, Gaspar, I4, I5. 
Cortereal, Miguel, I4, I5.

Coughlan, Rev. Laurence, I5I.

Cow Cove, 2 I 5 .

Crane v. Dubois, 234, 235.

Cremaillère, 215 .

Croc, IOI, 21 5-17, 220-3.

Cromwell, Oliver, $46,49,70,97$.

Crooked Lake, $165,167$.

Crowe, Captain Y., R.N., I05.

Cummings, A., I0 5,115 , I $24 n$.

Cuper's or Cupid's Cove, 56, 59, 64,83 .

Dameron, M., 222.

Darby, Nicholas, 143-4.

Dartmouth, 93, I38, $143,200$.

Dashwood, General, I61.

Davies, Captain W., R.N., 8o.

Davis or Davys, John, 20, 2I, 22, 46.

Davis Inlet, 203.

Davis Strait, 24.

De Ayala, I 2.

De Boes, 79.

De Brouillan, 89, 91-4.

De Costebelle, 89, 99 .

De Courtemanche, 132 .

Deep Sea Mission, 20I.

Deer Lake, I 33, 166, I 75, I 77 .

De Grat, Cape, I3 I.

De La Poype, 80.

The Delight, 38,39 .

De Monic, 89.

De Mons, Pierre du Guast, 50, 5 I, 54,55 .

De Montigny, 9I , 92 , 93, 99.

De Nesmond, 94-5.

Denys, Jean, 25.

De Pointis, 94, 95.

De Puebla, 9, I I, 12.

Derby, Edward H. Stanley, Earl of, 184 .

Dermer, Thomas, 58 .

De Ruyter, 78 .

De Sérigny, 94-5.

D'Espoir or Despair Bay, I25, 175 .

colonists beyond, 212.

Micmacs in, I40-I, 164 et seq.

De Subercase, 89, 99, Ioo.

Dethick, Isaac, 64.
Devonshire, 36, 59, 67, 71.

See Barnstaple, Bideford, Dartmouth, Exeter, Exmouth, Topsham, Torquay, \&c.

D'Ewes Coke, 150.

D'Haussonville, Comte, I 28.

D'Iberville, Pierre le Moyne, 90-4, 96.

Dog Bay, 122.

Dorsetshire, immigrants, 166, 2 I 3 , 2I 5. See Poole.

Douglas, Captain J., R.N., I 28.

Downing, John, 7o.

Downing, John, the Younger, 85 .

Downing, William, 76.

Drake, Sir Barnard, 36, 41, 42 .

Drake, Sir Francis, 36, 4I.

Drake, Captain F. W., K.N., I2I.

Duckworth, Sir J. T., I52.

Duff, Captain F. W., R.N., I3I.

Du Mont, 79.

Du Perron Thalour, 80.

Dunn, A., I 50.

Durham, John G. Lambton, Earl of, 22 I.

Duviviers, Admiral, 128.

East India Company, 45, 46, 53 .

Eastern Maelpeg Lake, $165,168$.

Easton, Captain Peter, 57,78 .

Edgell, Captain, R.N., 151 .

Edwards, Admiral Richard, I 36 , I5 2 .

Egeron, 87, 125.

Elgin, James, Earl of, 211.

Elgin, Victor A. Bruce, Earl of, 235.

Eliot, 15.

Eric the Red, 3, 9, I3.

Eskimo, 4, I 45-6, 202-3.

Estotiland, 9.

Exeter, 2I, 46, 47, 2 I 3.

Exmouth, 58.

Exploits Bay, I22, I 33-4, I 42.

Exploits River, 1 34, I 59-68, 174 .

ascent of, I 4 I-2.

colonized, I4I.

lumbering on, I76, I 79 .

Exploits Lumber Company, I77, I79. 
Falkingham, Captain Edward, R.N., 112.

Falkland, Lord, see Cary.

Falkland, North and South, 60-I, 64.

Falmouth, 47.

Felons, I I , 34, 49, 5 I ,56, I 40, I 44.

(King) Ferdinand and (Queen) Isabella, 6,7 .

Fermeuse, 16, 83,85 .

Fernandes, João, I4, I5, I6.

Ferryland, I6.

a boundary, 105 .

a colony, $61,70,83$.

a fort, 70, 100, 127, I54. See Boys Island.

Raid on, 79, 9r, 92.

a rendezvous, 30 .

roads to, $\mathrm{x}$. $\mathrm{I}$.

Fishery Regulations :

I62I, 57.

$1634,68-9$.

Commonwealth, $7 \mathrm{I}-2$.

I66I, 76.

1670, 77 .

1680, 85 .

1699, 96-7, 137.

I 775 , et seq., I $47-50$.

Fleming, Sir Sandford, r6o.

Fleur-de-Lys Harbour, 101, I 29.

Flower's Cove, 223.

Fogo Island, I6, 28, 237.

colonized, 122, 127 .

electoral Division, 185 .

Forest, H. H., 2 I9.

Forteau Bay, 181.

Fortrey, Samuel, 49.

Fortune Bay:

colony in, 88, I 24.

colonists from, 2 I 3 .

fisheries, $127,1_{4} 6,226-7$.

Inland routes to, $16_{5}, 168$.

trade with French, 2 I 0.

Fortune Head, 88, 260.

Fowey, 138.

Fox, Luke, 20, 21, 47.

France, Colonization by, 22-9, 49-52, 79-80, 87-9o.

France, recent agreements with :

I $857,220$.

I $885,223$.

1889-1904, 224 .
France, agreements with :

$1904,225$.

France, Treaties with :

See Amiens, Ghent, Paris, Ryswick, Utrecht, Versailles, Vienna.

Freels, Cape, I6, 88, I67, I 74 .

Freshwater Bay, $16_{7}$, 168 .

Freydis, 3.

Friesland, 9.

Frobisher, Sir Martin, 20, 3I, 34, 4I, 45 .

Frobisher Bay, 20.

Gambo River, I 76, I 79 .

Gander Bay, I 2 2, I68.

Gander River, I 22, I67-8, I79.

Gardens, $67,84,87$, I 25,183 .

Gardner, Dr. S., I 50, I 57 .

Gargot, Sieur, 79.

Gaultois, $213,236$.

Genge, Mrs., 2 I 5.

Geology, I73-5.

Ghent, Treaty of, 130.

Gibson, Colonel, 95, 98, ro4.

Gilbert, Adrian, 2 I.

Gilbert, Sir Humphrey, 20, 2 I, 34, $36-43,45,60,64,246$.

Gilbert, Ralegh, 47.

Gill, Michael, I I 5, I 2\%, 150.

Glasgow, I38.

Gledhill, Colonel, I 23 et seq.

Gloucester, Massachusetts, I97, 227.

Glover, Sir J., I97.

The Golden Hinde, 38, 39, 40.

Goose Cove, 215.

Gordon, Sir R., 34 .

Gorges, Sir Ferdinando, 34, 48, $5^{8}, 80$.

Gosnold, Bartholomew, 47.

Graham, Aaron, I 50, I53, I54.

Granada, 6, 7, 24.

Grand Bank, 88.

Grand Banks of Newfoundland, see Banks.

Grand Bay of New France, 132, 246, 249. See St. Lawrence Gulf.

Grand Falls, I 79, 238.

Grand Lake, I 16, 168, 175 .

Granville, George Earl, 230, 23 I.

Graves, Admiral Thomas, Baron, I 28, 133 . 
Graydon, Admiral John, 9S, I 12. Great Rattling Brook, $16 \%$.

Green Bay, I8I.

Greenland, 3, 5 .

Greenspond, I73, 237.

Grenville, Sir Richard, 36, 41, 42. Grey, Henry George, Earl, I84.

Griguets, I 45, 215.

Grotius, 55 .

Gnernsey immigrants, I 26, I 39, I44.

Guiana, 4I, 58, 184 .

Guibert, M., 222.

Guinea Company, 46.

Guy, John, 54, 56 et seq., 64, r42, I95.

Guy, Philip, 54.

Guzman, Mr., I6r.

Gweek, $\mathbf{I}_{3} 8$.

Hagthorpe, J., 3I.

Haie, E., 25, 26, 37 et seq., I 42.

Hakluyt, R., 34, 38 .

Halifax Commission, I97, 2 I 2.

Hall Bay, I62, I66-8, I 75.

Railway to, I 77-8.

Haly, Colonel, I 5 I.

Hamilton, Sir C., 184 .

Hamilton Inlet, I 44, 20I-3.

Handasyd, Major, 95, 104.

Harbour Grace, 56, 59, 64, 83, 85.

business centre, 205 .

fortified, $\mathrm{IO}_{5}$.

railway to, $177-8$.

riot, $\mathrm{I} 88$.

roads to, I 7 I, $I 88$.

Hare Bay, IOI, I8I, 209, 2 I6.

Harvey, Sir J., 184.

Hawkins, Sir John, 36, 41.

Hayman, Robert, 34, 59 et seq., 80.

Heart's Content, I60, I 7 I, I80.

Hebron, 202-3.

Helluland, 3,4 .

Hendry, Dr., 202.

Henry VII., 9-1 2, 25 I.

Henry VIII., I 9.

Hermitage Bay, as boundary, I 25.

Forests, 124 .

geology, I 74 .
Hermitage Bay, as sub-colony, 88 , I 24 et seq.

whaling, 236.

Highlanders, 175.

Hill, Sir Stephen, I 7o, I 76, I 97.

Hill, W., 63.

Hinton, William, 76.

Hitchcock, Captain R., 3 I et seq., $76,77,84$.

Holman, Captain W., 9I, 92, 94.

Holyrood, I I.

Hopedale, $1_{4} 6,202-3$.

Hopi, 4, 5 .

Hore, 19, 20, 25, 27.

Horses, 62, 92, I56, I 72,183 .

Howley, James P., I6I, I 77.

Hudson, Henry, 20, 21.

Hudson Bay, 2 I, 90, 94 .

Hudson Bay Company, I35, 202-3.

Hudson Strait, 20, 2 I, I 47, 201.

Humber River, I33-4, I 40-I, I66-7.

Humber Sound or Arm, I66, I75.

Hutchings, G., I 50 .

Indian Beothics, 29, 30, 57, I $4 \mathrm{I}-3, \mathrm{I} 6 \mathrm{I}-9$.

Micmacs, 29, 79, 9I, 93, 99, I03, I 25, I $32,140-1, I 43$, I $6 \mathrm{I}-70$.

Montagnais, I 32, I 43-6, I62, 203.

Nascaupi, I4.

others (Abenaki, \&c.), 9I, 93.

Indian Brook, $\mathbf{I} 66$.

Indian Harbour, 20r.

Ingornachoix Bay, I32, I 33, 209, $215,217,220$ et seq.

Irish colonisation, 60-I, I 20, 252.

Irish immigrants, 64,79, I 20-1, I 23, I 27, I 36, I 39 et seq., 240.

Island Lake, 167.

Jackson, Rev. John, 98.

Jago, I I 4.

James, Captain Thomas, 20, 2 r, 47.

James Bay, 202.

Jersey immigrants, I 26, I 39, I 41, I 44, 20I, 2 I 3,2 I 5.

Joli, Mount, I 35, 228.

Jukes, Joseph Beete, I6I, I 70, I 73,2 IO. 
Junction Brook, 166.

Karlsevne, 3, 4, I4, 230.

Keats, Captain Sir R., R.N., I $5^{2}$, I92.

Keen, W., I I 3, I I 4, I I 5, I 2 I, I 22 , 150.

Kennedy, Sir W., 209.

Kent, John, $187-8$.

Keyling, Sir J., 49.

Kielley, Dr., I 88.

Killinek, see Burwell.

King George IV's Lake, 161, 168.

Kirke, Sir David, 69-7I.

Kirke, George, 85 .

Kjalarnes, 4, 5 .

Knight, John, 20, 2 I, 28.

Koksoak River, 202.

Labouchere, Henry, 220, $22 \mathrm{I}$.

Labrador, colonization of, $\mathrm{r}_{43}-4$, 199-203, 209.

part of Newfoundland, 39, 55 , $143,146-7$.

railways, $\mathbf{I} 8 \mathrm{I}$.

steamers, $\mathrm{I} 78$.

steppingstone to Newfoundland, I3, I4, 16, 19, 2 I, 23.

Treaty Rights over, I35, 220 , $228-9$.

La Hontan, Jean de, 97.

La Hune, Cape, 212, 213.

La Manche, I80.

L'Anse-à-Loup, I 43 .

La Poile Bay, I74, I85, 213.

Lapps, 170.

Larkin, George, I03-4.

La Roche, 5 I.

La Rochelle, $25,79-80$.

La Tana, 6,8 .

Latham, Lieutenant R., 99.

Leake, Admiral Sir John, 98, Ior, I05.

Lee, Captain F. H., R.N., II2, I1 6, I 18, I 20.

Leigh, Charles, 4I, 43, 250.

Leiv, son of Eric, 3 .

Le Marchant, Sir J. Gaspard, 173 , I $97,240$.

Lemoine, 222.

L'Hermitte, 90, 92, 93, 99.

Lilburne, Lieutenant, 104-5.
Little Bay, 180,18 r.

Little Harbour, r4I.

Liverpool, I 38, 205.

Lloyd, Major, 100-2, 104-5.

Loch, Captain Granville G., R.N., 2 ro.

Locke, John, II 3 .

Long Harbour, 227.

Lucas, Lieutenant Francis, I 46.

Lumbering, I 76-7, I 79, 180 .

MacGregor, John, I97.

Mackinson, Mr., I 72 .

Mckay, Smith, 180.

Magdalen Islands, 23, 26, 28, 29, $4 \mathrm{I}, 43, \mathrm{I} 35, \mathrm{I} 43,146$.

Makkovik, 203.

Mandeville, Sir John, 7 .

Manoel, King of Portugal, 14 .

Mansfield, William, Earl of, I43.

Manwaring, Sir Henry, $58,78$.

Markland, 4 .

Martin V, Pope, 6.

Martir, 87 .

Mason, Captain John, $58,59,78$.

Merichon, 87, 260.

Mevagissey, 138 .

Millais, J. C., I6r.

Milne, Captain, R.N., 213.

Mines, \&c., I6I, I80-4.

Miquelon Island, $16,88,107,124$, I 28, I 36, 218.

Moody, Colonel, 98, 99, 104-5, I 23 et seq.

Moravian Missions, 146, 202-3.

Morris, Hon. Patrick, I97.

Mullock, Thomas, R.C. Bishop of Newfoundland, 197 .

Murray, A., 16I.

Murray, Sir Herbert, I 89.

Nachvak, 20r, 203.

Nain, $\mathrm{I}_{4} 6,203$.

New England :

aborigines and, 146 .

colonization of, $5,47,48$.

Newfoundland overlapped by 50.

Newfoundlanders go to, 49, 76 , II 9, 148-9.

raids from, 144,154 . 
New Englandrescue from, 156 .

trade with, 8I , 82, I I 9, I 39, I49. Washington Treaties and, 2 I I-I 2. whales, walrus, \&c. , and, 146.

New found(ed) Isle or Island, I I, I 3,15 .

New found Land, I 5, 246, 248, $25 \mathrm{I}$.

Newfoundland boundaries, 15,39 , $50,55,69,143, I_{4} 6-7$.

statistics, 182-3, 196, 205, 208, 239, 241.

unity, 69, 96, 106-7, x10, 179, 218 ; Appendix $F$, and compare Bonavista Cape, Trepassey, \&c.

Newfoundland Dog Lake, 165, 167.

Newfoundland Light Infantry, I 36.

New France or Nova Francia, 22, 132. See Canada.

New Harbour, I 7 I.

New Isle, II.

New Land or Nye Land, 9, 22, 4I, 243.

Nielsen, Adolf, $230,236$.

Noble and Pinson, 143-4.

Noel Paul's Brook, I67.

Normans, 19, 25, 62, 216.

Norris, Sir John, 94-5, 97.

Northampton, Henry Earl of, 34, 54.

North-east Arm or Bay, 125.

North-west House, 203.

Norumbega, 22.

Notre Dame Bay, 162, I 74-5.

Inland Routes to, 162, 167-8.

lumbering at, $\mathrm{I} 76$.

whaling in, 236 .

O'Donel, Bishop, I 5 I.

Ogle, Sir Chaloner, R.N., III.

Okkak, 146, 202-3.

Osborn, Captain Henry, R.N., I 2 I.

Ougier, Peter, $\mathbf{I} 72$.

Oxford, T., 85.

Pack, Robert, $\mathrm{I} 72$.

Palliser, Admiral Sir Hugh, I31, 143, 146.

Paradise Sound, 87.

Paris, Treaty of, I 763, I28-9, I 31

et seq., I 35, I 43-4.

$1814,130,217,218$,
Parkhurst, 25, 143.

Parson's Pond, 181 .

Pasqualigo:

Lorenzo, Io, II.

Pietro, I 3.

Pasture Land, 67, I 24, 172.

Payne, E., 59.

Payne, W., 63.

Pearl, Sir J., 172.

Pearse, 76 .

Peckham, Sir G., 34, 36, 38, 47 .

Percy, Captain, R.N., I 16, 120.

Petit MaÎtre, Ior, 145 .

Petit Nord, 28, 29, 91, 162, I79.

Beothics not in, 162 .

Colonization of, 2 I 4 et seq.

Eskimo in, 145-6.

French in, 220, 222.

raid on, IOI.

railways, $\mathbf{1 7 9}$, I8I.

Petty Harbour :

a boundary, 60, 61, 63 .

population at, 83 .

Portuguese at, 58 .

raid on, $79,9^{2}$.

Pickmore, Admiral Sir F., $155-7$.

The Pike, 156.

Pilley's Island, $18 \mathrm{I}$.

Piper's Hole, I68.

Pitt, William, Earl of Chatham, I 29.

Pitt, Fort, $143,146$.

Placentia ;

English colony under Nova Scotia, 123 et seq.

French colony under Canada, 79-80, 87-9, 107, I 24 et seq.

Treaty of Utrecht and, 106-7.

Placentia Bay :

English colony bounded by, $55,59,6 \mathrm{r}, 64,67,260$.

French Basques, \&c., visit, I6, $25,26,28,30$.

French colony on, 87,88 .

Indians visit, 29.

Inland routes to, 93, 168.

Spanish ship in, 97 .

Placentia, Great or Grand :

beach at, $\mathrm{I} 94$.

colony at, 87-9.

English in, 123 et seq.

fortified, 89, I $_{3} 3, \mathrm{I}_{2} 7,154$. 
Placentia, Great or Grandraids from, 92-4, 99-100, 102. raided, $90,98-9$. railway to, 178 . reconnoitred, Ioo. roads to, $126,17 \mathrm{I}$. size, 2 10.

Placentia, Little, 87,89 , I 7 I.

Plymouth, 38,47 .

Pollexfen, John, 49.

Ponchartrain, Fort, 29, I 32.

Poole, Sir W., 82.

Poole, I 26-7, I38, I 39, I44, 201, 205.

Popham, Captain George, 47.

Popham, Sir John, 34, 47, 53, 54, 60.

Population, 82-4, 88, 137-8, I 74, I 76, $240-1$.

Port-à-Port, 28, 132, 214 .

Port-au-Choix, 97, 132, 215, 217, $220 n$., 222.

Port-aux-Basques, see Basques.

Port de Grave, 56.

Portugal :

claims and discoveries, 5-7, 14-16, 22, 27.

fishermen of, $19,23,25-6,38$, $58,64,82$.

fishermen excluded, 97, I 10.

trade with, 205 .

Portugal Cove, I 7 I.

The Potomac, 234.

Powell, Captain, 6r.

Powell, Lieutenant, I04.

Pring, Martin, 47.

Pringle, Colonel, 15 I.

Purlican, 30.

Pynne, John, 85.

Quidi Vidi, 83, 85, 128, 193.

Quirpon, 22, 25, 135, 145, 146, 2 I $5,216,228$.

Race, Cape, 16, 30.

as boundary, $67,77,83,96,97$, IIo.

Ragged Bay, I22.

Railways, $160,177-8 \mathrm{I}$.

Raimondi, Raimondo di, of Soncino, IO, II.
Ralegh, Sir Walter, 21, 34, 35, $36,38,40-2,45,47,48,248$.

The Ralegh, 38 .

Rama, 203.

Ramea Islands, I35, 228 ; also old name for Magdalen Islands, q.v. ; see 249.

Random Island, 159 .

Ray, Cape :

as boundary, 134 .

colonists pass, 2 I 3-I 4 .

French colony near, 125, 132 .

Micmacs hunt near, I 25, I32, I 40.

mountains, 174 .

Rich Point and, 133 .

Treaties refer to, I34, 135 .

Rayner, Captain J., 76.

Red Indian Lake, I4I-2, I6I, $162,167$.

Red Island, 214.

Reeves, John, I 38, I 52, I 53-4.

Reid, R. J., I 8 , I79.

Renewse, 25, 67, 83, 92, 171.

Rich, Point, 23, 106, 129,132 et seq.

Richery, Admiral, I 36-7.

Richmond Gulf, 202.

Rigby, William, 70.

Rigolet, 203.

Roberval, Jean François de la Roque, Marquis de, 23, 24, 25 , 26,51 .

Robinson, Captain R., R.N., 76, 80,86 .

Rodney, Admiral George Brydges, Baron, 121.

Rook, II 4.

Rosebery, Archibald Primrose, Earl of, 23I.

Routh, Richard, I 40.

Royal Newfoundland Fencibles, I 36.

Rangers, 136 .

Regiment, I39.

Rupert, Prince, 70, 78.

Russell, Captain, R.N., 82.

Rut, John, 19, 25, 26.

Ryswick, Peace of, 86.

Sable Island, 39.

St. Anne (C.B.I.), 163. 
St. Anthony, I 45, I 70, 201, 2I 5 , 216, 223.

St. Barbe Bay, 215, 216, 219-23.

St. Francis, Cape, 16, 30, 63 .

St. George Bay:

agriculture near, I 73, I 75 .

Canadians fish in, 2I4, $221-2$.

colonies at, I32, I34, I 4I, 237 .

discovered, 27,28 , I 32 .

French near, 218 et seq.

herring of, 220,233 .

Inland ways to, 159,166 et seq.

Indians at, 29, I4I.

political institutions, 185,219 et seq., 22 2-3.

population of, 2 I 4 .

St. George, Cape, 23.

St. John Bay, I 32 .

St. John, Cape, IoI, I33-4, $216-7$.

St. John Island, $215,222,223$.

St. John River, I $43,147$.

St. John's :

city, II 5-16, I 78, I86, 192-3.

colony, 63-4, 89.

electoral district, I84-5.

fortified, $70,85,86,95,98$ et seq., I $27, \mathrm{I}_{36} 6, \mathrm{I}_{54}$.

Gilbert at, 38 et seq., 64 .

population of, 83 .

raided, $78,79,92,98-9$, I02, I $28,136$.

a rendezvous, $14,16,19,23$, $25,26,58,64$. roads, 151,17 I.

sales of houses and land, I50, I $51,{ }^{2} 52$.

St. Julien, IOI, 2 I 5.

St. Lawrence, Great, 28.

Little, 27 .

St. Lawrence, Gulf of, 23-4, 26.

English enter, 4I, 43, I $3^{2}$.

Jerseymen in, 144 .

Treaty Rights in, 2I I, 228-9.

St. Lawrence Island, old name for Cape Breton Island, 243 .

St. Loo, 138.

St. Lunaire, 215 .

St. Malo, 88, 91, 92, IоI, 216, 222, 233.

St. Mary Bay, 28, 64, 79, 122, I 40,172 .

Cape, 28, 55, 79.
St. Ovide, $89,92,93,102-3$.

St. Pierre Island :

discovery, 16, 23, 25, 28.

French sub-colony, 88, 124 .

new French capital, 2 I0, 2I6-I 7.

Trade with, I 26, 210.

Transfer and Re-transfer, I07, I 28, 136-7, 218.

Salisbury, Robert Cecil, Earl of, 2 I. Salisbury, Robert, Marquis of, $230,23 \mathrm{I}$.

Sallee Rovers, 78 .

Salmon Cove, 61,63 .

Salmonier, 122.

Sandwich Bay, I44, 20 I.

Saunders, Port, I 33, 21 7, 22 I.

Scott, Captain J., R.N., 122.

Selous, F. C., I6r.

Seven Cities (mythical), I4, I5.

Shannoc Brook, 164, I67.

Sidney, Sir Philip, 38.

Skeffington, George, 99, Ioo, I 2 I-2.

Skinner, Colonel, I 5 I.

Slade \& Co., I 44.

Slaney, Henry, 54.

Slaney, John, 54, 63 .

Slaves, 6, 14, I 39, 140.

Smith, Captain John, 34 .

Smith, Admiral Sir Thomas, I 20, $12 \%$.

Smith's Sound (Trinity Bay), I59.

Snook's Arm, 236.

Somersetshire, 47, 48, 6I. See Bristol.

Sop Arm, I34, I 44 .

Southmead, II4.

Spain :

claims and discoveries, 6-9, 22 , 27.

colonial methods of, 24 .

fishermen of, $25-7,28,38$ et seq., 82, 97, 132, 197 .

fishermen excluded, 97, IIO, 129.

Spaniards' Bay, I 7 I.

Spanish Armada, 4I.

Spear, Cape, 14, I6.

The Squirrel, 38, 39, 40.

Stourton, Erasmus, 57, 62 .

Straumfjörd, 4, 5 . 
Sully, Maximilien, Duc de, 48, 5 I. The Swallow, 38, 39 .

Swanley, Captain R., 76.

Taverner, Captain William, II2, I 24, I 25, I3I-2, 217.

Taylour, Captain, R.N., 105.

Telegraphs, I60, I 80 et seq.

Temple Bay, 143 .

Terra Nova, 15, 16. See New Land.

Terranova River, I68, I 79.

Thirkill, Launcelot, I I.

Thomas, Mr., I 5 .

Thomas, H. P., I 72.

Thorhalli, 3,4 .

Thorvald, 3,4 .

Thorvard, 3,4 .

Tilt Cove, 180 .

Tilton, 178.

Tisquantum, 58 .

Topsail, I71.

Topsham, I 38.

Torbay, $128,17 \mathrm{I}$.

Tordesillas, Treaty of, $7,10,12$, $27,40$.

Toscanelli, 6, 7 .

Torquay, 201, 205.

Townsend, Admiral, 120.

Trepassey:

Boundary, $67,72,83$, 110 .

colony, $60,64,83,90$.

colony beyond, 64,122 .

Pasture land at, 67,172 .

raid at, 62,90 .

Treworgie, John, $7 \mathrm{I}$.

Trinity Bay:

Beothics in, 29, 57, 142 .

colonized, $59,6 \mathrm{I}, 67,96$.

Fishermen in, 29, 30, 57 .

fortified, 100 .

inland routes to, 93, I 59 et seq., I79.

raid on, $93,99,128$.

seals in, I2I.

Trinity Harbour, $67,127,128$.

Triton, 176 .

Twillingate :

business centre, 237 .

colonized, I 22, I 29, I 38 .

electoral division, 185 .

starting-place for the north, 201.
Underdown, Captain, R.N., Iог.

Ungava Bay, 202.

United States, conventions, Treaties, and agreements with :

I818, I30, 209-10, 214, 228-9, 230-I.

1886 et seq., 23 I.

1888, Bayard-Chamberlain, 232.

1890, Blaine-Bond, 232.

1902, Bond-Hay, $232-3$.

1905 et seq., 234-5.

I907, 235 .

I9I0, arbitration, 236, 253-62.

See Versailles, Treaty of ; Washington, Treaty of.

Utrecht, Treaty of, 106-7, 109, I I 0, I 32, I 35, I 44, I64, 2 I 8, 2 I 9.

Vaughan, Sir William, 56, 58, 59, $60,61,78$.

Verde Bay, 67 .

(Cape) Verde Islands, 7, I6.

Verrazzano, 22.

Versailles, Treaty and Declaration of, I 30, I3 I I I33-6, I 44 , 2 I 7-19.

Verte, Point, $87,89$.

Vienna, Treaty of, 130.

Vineland, 3,4 .

Virginia, 42, 47, 48, 50, 54 .

Virginia Company, 50, 54 .

Walker, Admiral Sir B., 22.

Walker, Admiral Hovenden, 102.

Wallace, Admiral Sir James, R.N., I36.

Walsingham, Sir Francis, $21,3^{6}$, $38,40,4^{2}, 246$.

Warde, Mr., 15.

Washington, Treaty of, I 854, 2 I I.

Washington, Treaty of, 1871,212 , 227.

Waterford, $\mathrm{r} 38$.

Webeck, Cape, 20I-3.

Wellsted, Mr., 6r.

West Indies :

colonization of, 36 et seq., 42, 245 .

Fishermen from, I 39, I 40 .

Newfoundland attacked from, 90, 94-5, 98 .

Newfoundlanders to go to, $7 \%$. trade with, 90, 149 . 
Weston, Mr., II 4 .

Weymonth, George, 20, $21,47$.

Whaling, $21,26,27,28,146,147$, $236-7,239$.

Wheler, Admiral Sir Francis, 90. Whitbourne, Sir Richard, 29, 34, $58,59,60,6 \mathrm{I}, 78, \mathbf{1} 42$.

Whitbourne, I77, 178 .

White, John, 34, 35 .

White Bay, 28, IOI, I29, I44, I67, I68.

White Bay Constituency, 185 .
White Bear Bay, 27, 29, I4I, 164. White Bear River, 165, 167.

Whiteway, Sir W., I97.

Williams, Major Griffith, I40, I $5 \mathrm{I}$.

Williamson, Captain Herman, 90.

Willis, Mr., I6r.

Winton, Henry, 187-8.

Wolsey, Cardinal, 19, 46.

Wyett, Sylvester, 25, I 32 .

Wynne, Captain E., 61 .

Oxford: Printed at the Clarendon Press by Horace Hart, M.A. 



THIS BOOK IS DUE ON THE LAST DATE STAMPED BELOW

AN INITIAL FINE OF 25 CENTS WILL BE ASSESSED FOR FAILURE TO RETURN THIS BOOK ON THE DATE DUE. THE PENALTY WILL INCREASE TO 50 CENTS ON THE FOURTH DAY AND TO \$1.00 ON THE SEVENTH DAY OVERDUE.

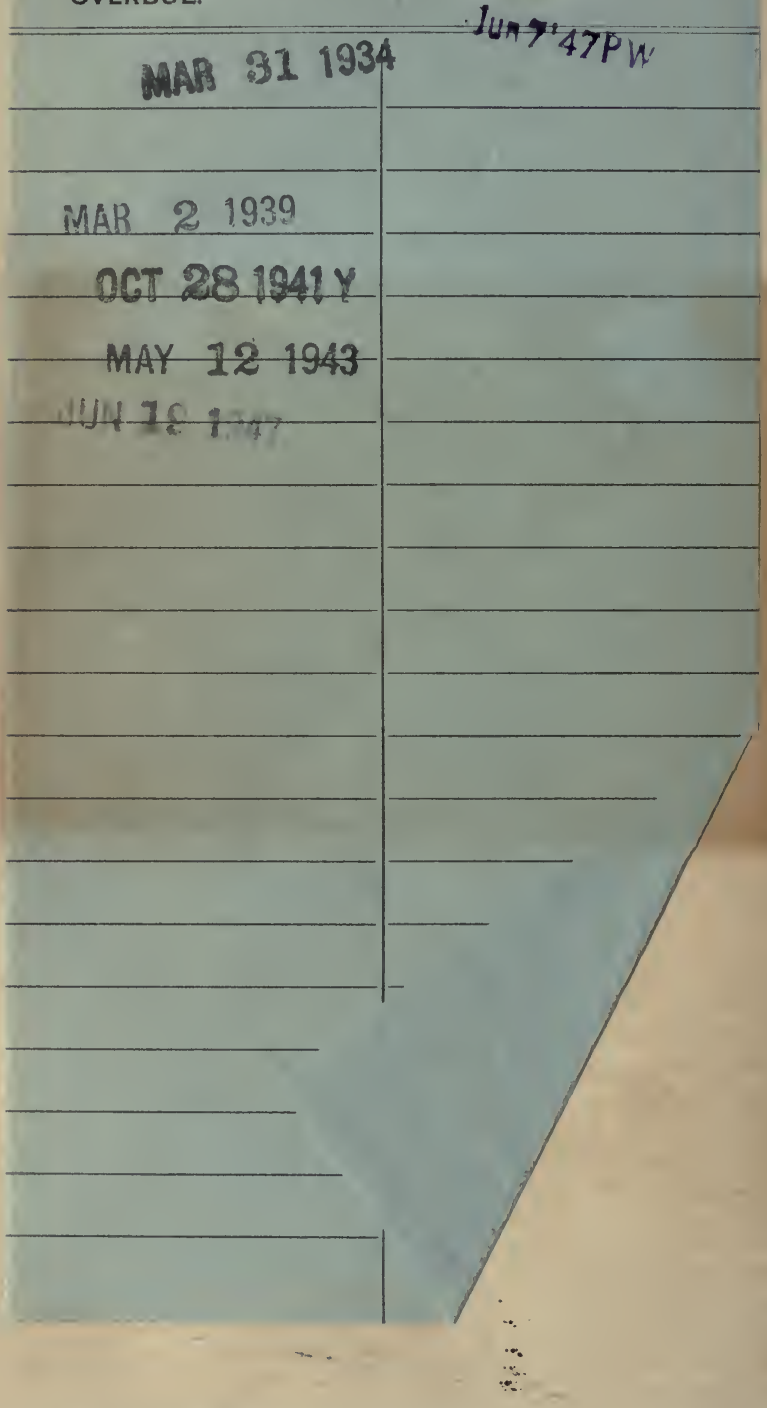




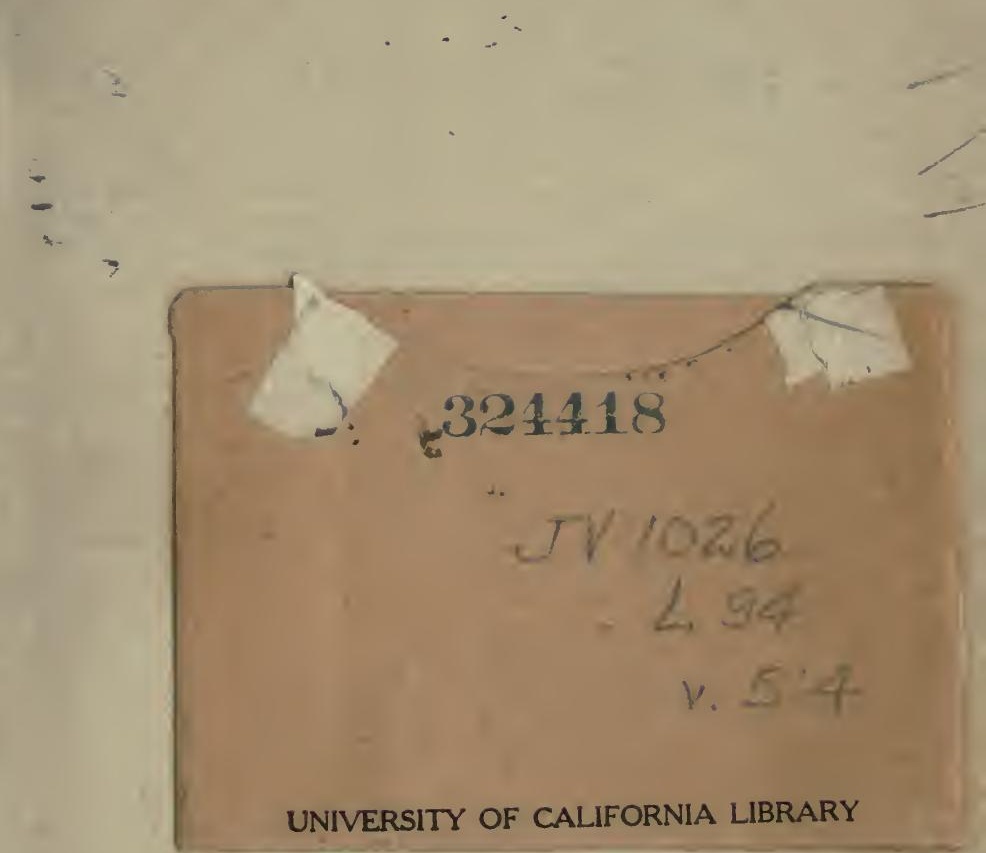

th

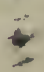

a 
